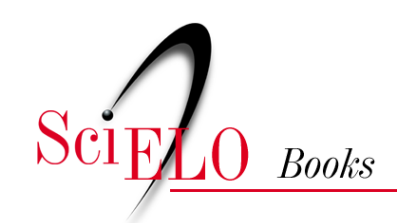

\section{Pesquisas e proposições pedagógico-curriculares na escolarização inicial da educação básica}

\author{
Maria Bernadette Castro Rodrigues \\ Fabiana de Miranda Rocha \\ Juliana Hass Massena \\ (orgs.)
}

\section{SciELO Books / SciELO Livros / SciELO Libros}

RODRIGUES, M.B.C., ROCHA, F.M., and MASSENA, J.H., orgs. Pesquisas e proposições pedagógico-curriculares na escolarização inicial da educação básica [online]. Porto Alegre: Editora da UFRGS, 2017, 324 p. ISBN 978-85-386-0472-3. Available from: doi: 10.7475/9788538604723. Also available in ePUB from: http://books.scielo.org/id/3vrq5/epub/rodrigues-9788538604723.epub.

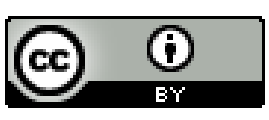

All the contents of this work, except where otherwise noted, is licensed under a Creative Commons Attribution 4.0 International license.

Todo o conteúdo deste trabalho, exceto quando houver ressalva, é publicado sob a licença Creative Commons Atribição $\underline{4.0}$.

Todo el contenido de esta obra, excepto donde se indique lo contrario, está bajo licencia de la licencia Creative Commons $\underline{\text { Reconocimento } 4.0 .}$. 


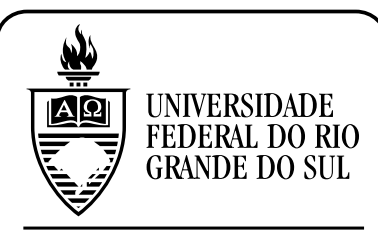

Reitor

Rui Vicente Oppermann

Vice-Reitora e Pró-Reitora de Coordenação Acadêmica Jane Fraga Tutikian

EDITORA DA UFRGS

Diretor

Alex Niche Teixeira

Conselho Editorial

Álvaro Roberto Crespo Merlo

Augusto Jaeger Jr.

Carlos Pérez Bergmann

José Vicente Tavares dos Santos

Marcelo Antonio Conterato

Marcia Ivana Lima e Silva

Maria Stephanou

Regina Zilberman

Tânia Denise Miskinis Salgado

Temístocles Cezar

Alex Niche Teixeira, presidente 


\section{S) \\ $\frac{\text { UFR̈GS }}{\text { EDITORA }}$}

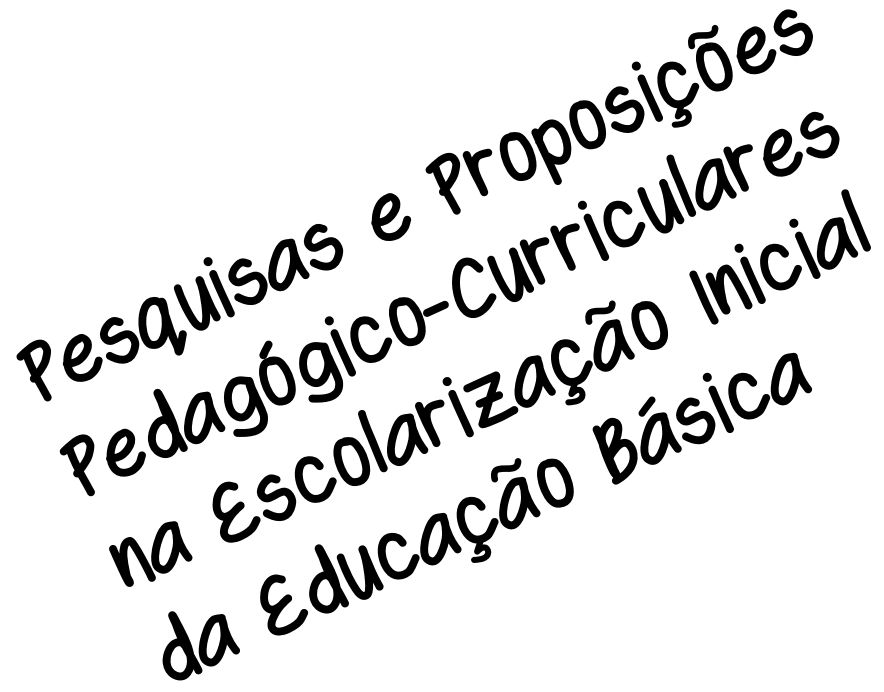

Maria Bernadette Castro Rodrigues

Fabiana de Miranda Rocha

Juliana Hass Massena

Organizadoras 
(C) dos autores

$1^{\text {a }}$ edição: 2017

Direitos reservados desta edição:

Universidade Federal do Rio Grande do Sul

Revisão: Dóris M. Luzzardi Fiss

Revisão editorial: Cristina Thumé Pacheco

Capa e projeto gráfico: Clarissa Felkl Prevedello

Editoração eletrônica: Cláudio Marzo da Silva

A grafia desta obra foi atualizada conforme o Acordo Ortográfico da Língua Portuguesa, de 1990, que entrou em vigor no Brasil em $1^{\circ}$ de janeiro de 2009.

P474 Pesquisas e proposições pedagógico-curriculares na escolarização inicial da educação básica / organizadoras Maria Bernadette Castro Rodrigues, Fabiana de Miranda Rocha [e] Juliana Hass Massena. - Porto Alegre: Editora da UFRGS, 2017.

326 p.: il. ; $16 \times 23 \mathrm{~cm}$

Inclui figuras e tabelas.

Inclui Referências.

1. Educação. 2. Educação básica. 3. Escolarização inicial. 4. Educação de jovens e adultos. 5. Alfabetização. 6. Letramento. 7. Aprendizagem. 8. Propostas curriculares. 9. Formação docente. I. Rodrigues, Maria Bernadette Castro. II. Rocha, Fabiana de Miranda. III. Massena, Juliana Hass. IV.

CDU 373

CIP-Brasil. Dados Internacionais de Catalogação na Publicação.

(Jaqueline Trombin - Bibliotecária responsável CRB10/979)

ISBN 978-85-386-0368-9 


\section{Sumário}

Apresentação 9

Maria Bernadette Castro Rodrigues

Fabiana de Miranda Rocha

Juliana Hass Massena

\section{Parte 1 Alunos em foco}

1

As dificuldades de aprendizagem de Vítor:

aprofundando seus fatores e buscando possíveis soluções 21

Angela Cristina Sthamer Gieseler

2

Planeta Rooda 2.0: elaboração de projetos

direcionados a alunos com dificuldades de aprendizagem 45

Tássia Priscila Fagundes Grande

Patricia Alejandra Behar

3

Alfabetização e letramento: a produção

de Histórias em Quadrinhos em ambiente informatizado 75

Fabiana de Miranda Rocha

4

Leitura do jornal, leitura do mundo: reflexões sobre uma prática de letramento numa turma de alfabetização de jovens e adultos 95 Bruna da Cunha Fagundes 
5

"Caprichem nas folhinhas":

a infantilização das práticas pedagógicas e docência na EJA 117

Márjori Bez Reus

6

Relações de gênero nos sites

de jogos infantis: entre a beleza e a força 141

cristiane Luiza Abbud Flores

7

¿u não escuto nada, só vejo:

narrativas sobre "ser surdo" e a educação bilíngue 165

Priscila de Abreu Bortoletti

8

Sentidos da escola para os jovens e adultos surdos 191

simone de Brum

Parte 2 Propostas curriculares em foco

1

Práticas avaliativas e progressão

continuada na rede municipal de Eldorado do sul/RS:

a ênfase está nas aprendizagens dos alunos? 203

Juliana Hass Massena

2

(Re)Conhecendo o povo Mbya Guarani: um olhar para os kyringue 225 Andréia Rosa da Silva Kurroschi

3

Capoeira Angola na escola:

uma alternativa à formação integral dos estudantes

247

Viviane Malheiro Barbosa 
Parte 3 Formação docente em foco

1

Pedagogia de Projetos:

depoimentos de estagiárias de Pedagogia 273

catarine Machado Costa

2

0 que ensinam os Estágios de Docência?

A formação docente no curso de Pedagogia da UFRGS 289

Lidiane da Silva Machado

3

Memórias da formação:

aprendendo a conhecer $e$ a ser aquela que ensina e aprende 311 Isaura Teresinha Silva Barbieri

As autoras 321 


\section{Apresentação}

Pesquisas e proposições pedagógico-curriculares na escolarização inicial da Educação Básica reúne estudos de alunas egressas do curso de Pedagogia da Universidade Federal do Rio Grande do Sul (UFRGS) sistematizados por ocasião da elaboração dos trabalhos de conclusão de curso, no primeiro semestre de 2013.

O exercício da docência exige do professorado pensar ações pedagógico-metodológicas intencionais e, nisso se faz primordial o nexo ensino-pesquisa. Nos cursos de formação docente, o aluno-docente-pesquisador precisa ser orientado na prática da pesquisa para aprender a se inquietar, a se indagar, problematizando os contextos escolares e, dessa forma, tendo condições de produzir um repertório de alternativas pedagógicas. No curso de Pedagogia da Universidade Federal do Rio Grande do Sul, os Trabalhos de Conclusão de Curso (TCC) consistem

[...] na prática de pesquisa, através das seguintes etapas: 1. elaboração de um projeto de investigação com base ou nas experiências do estágio de docência, ou em outras práticas pedagógicas desenvolvidas ao longo do curso; 2. produção escrita decorrente da referida investigação. O citado trabalho deve configurar-se como um ensaio contendo resultados da pesquisa proposta e desenvolvida, abordando temáticas novas ou já estabelecidas no campo da Educação. Deve, também, evidenciar elaboração teórica e rigor conceitual nas análises. Não serão aceitos textos que se restrinjam à revisão bibliográfica ou a relatos de experiências. ${ }^{1}$

${ }^{1}$ Trecho das Normas TCC do Curso de Pedagogia/UFRGS, disponível em: <http:// www.ufrgs.br/faced/comissoes/comgrad/normas_TCC.pdf>. 
Estas normas estão em vigência desde o ano de 2007, ocasião em que se iniciou a nova proposta curricular do curso. Nas apresentações orais públicas dos trabalhos, ocorridas ao final de cada semestre letivo, os comentários a respeito dos mesmos são recorrentes no que se refere às relevâncias das abordagens, às metodologias escolhidas, aos achados apresentados e à necessidade de dar divulgação aos estudos. Daí a origem desta publicação que reúne estudos realizados em 2013.

Para um melhor entendimento do processo de elaboração dos estudos apresentados neste livro, entendemos que se faz necessário um comentário sobre a importância da disciplina Reflexão sobre a Prática Docente - 6 a 10 Anos, no que se refere à constituição de metodologias investigativas pelas autoras.

$\mathrm{Na}$ última etapa do curso, $8^{\circ}$ semestre, as alunas efetuam matrícula para a orientação do trabalho de conclusão, que consiste em assessoramento individual com o/a professor/a orientador/a no decorrer do semestre letivo. Além disso, as alunas também cursam uma das disciplinas do grupo obrigatórias-alternativas dessa etapa, a saber: Reflexão sobre a Prática Docente - 0 a 6 anos; Reflexão sobre a Prática Docente - 6 a 10 Anos; e Reflexão sobre a Prática Docente - EJA. A súmula dessas disciplinas é muito semelhante ao dar ênfase à "orientação da escolha do tema, do planejamento, da execução e da divulgação de um trabalho de investigação a partir da prática docente", diferenciando-se apenas na ênfase da faixa etária da prática, como pode ser observado pelo título das mesmas. A maioria das autoras deste livro cursou a disciplina Reflexão sobre a Prática Docente - 6 a 10 Anos, ministrada pela profa. Dra. Elisabete Maria Garbin, e, por essa razão, fazemos algumas considerações pontuais sobre o funcionamento dessa disciplina.

No plano da referida disciplina, disponibilizado às alunas, constam os seguintes objetivos: “orientar na escolha de temática de pesquisa, na elaboração de projeto e seu desenvolvimento relacionado às experiências 
docentes vivenciadas no curso de Pedagogia e estágio, com vistas à elaboração do Trabalho de Conclusão de Curso; e, construir condições para que os/as futuros/as professores/as aprofundem, reflitam e desnaturalizem determinadas posições de sujeito-pesquisador a partir dos conhecimentos oriundos de diversos campos teóricos das experiências vividas durante o curso e estágio, para o desenvolvimento de pesquisas relacionadas à faixa etária escolhida para atuação docente". Também está explicitada, no plano da disciplina, a especificidade da experiência de aprendizagem: "em termos metodológicos, a disciplina visa instrumentalizar teórico e praticamente alunas formandas em fase de construção de Trabalho de Conclusão, utilizando-se de produções textuais acerca do andamento dos trabalhos, apresentações orais dos trabalhos em andamento, construções individuais de mapas conceituais acerca dos temas em estudo, leituras de produções acadêmicas afins às temáticas eleitas e palestras, envolvendo mestrandos e doutorandos do PPGEDU/UFRGS sobre seus trabalhos de investigação".

Conforme depoimentos das autoras que cursaram a disciplina, os objetivos se efetivam em aulas que colaboram para a organização da pesquisa necessária ao trabalho de conclusão, uma vez que a professora incentiva leituras de estudos investigativos e promove, em sala de aula, discussões sobre metodologias investigativas. Também favorece discussões sobre o andamento das orientações individuais, auxiliando nos esclarecimentos.

Esta publicação visa destacar a relevância e a necessidade de um exercício docente na Educação Infantil e/ou nos Anos Iniciais do Ensino Fundamental (seja em classes de crianças, seja em classes de jovens e adultos) que compreenda o nexo primordial entre ensino-pesquisa. Nosso desejo é contagiar as professoras e os professores que atuam na escolarização inicial da educação básica de modo que, sempre mais, incorporem a pesquisa ao seu trabalho como elemento constitutivo 
da docência, na busca de proposições pedagógico-curriculares que promovam um ambiente de aprendizagens profícuas.

Escolhemos organizar os estudos investigativos no livro dando ênfase aos focos de problematização das pesquisas realizadas: alunos, propostas curriculares e formação docente. As leitoras e os leitores poderão perceber que estes focos são meros artifícios, entretanto, entendemos que podem servir para dar ênfase aos temas que inquietaram e motivaram as investigações produzidas com vistas às reflexões, problematizações e proposições no âmbito escolar em classes iniciais.

As oito pesquisas que compõem a Parte 1 deste livro focam o aluno. Nos artigos estão expostas as inquietações e os estudos das alunas-docentes-pesquisadoras com fins de produzir alternativas pedagógicas em sala de aula em prol das aprendizagens dos alunos.

"As dificuldades de aprendizagem de Vítor: aprofundando seus fatores e buscando possíveis soluções", de Ângela Cristina Sthamer Gieseler, é um estudo de caso sobre um aluno do $4^{\circ}$ ano do ensino fundamental, de uma escola pública, que apresentava dificuldades de aprendizagem na área de leitura e de escrita. O estudo teve como objetivo investigar os fatores que podiam estar causando/agravando tais dificuldades, bem como auxiliar o aluno na superação das mesmas, por meio de ações psicopedagógicas planejadas e desenvolvidas com ele. Na sua argumentação, a aluna-docente-pesquisadora posiciona-se sobre o entendimento de dificuldades de aprendizagem e transtornos.

"Planeta Rooda 2.0: elaboração de projetos direcionados a alunos com dificuldades de aprendizagem", de Tássia Priscila Fagundes Grande e Patricia Alejandra Behar, trata-se de uma pesquisa do tipo estudo de caso realizada a partir de um grupo focal em que participaram alunos de um curso de extensão, com tema preestabelecido. Teve como objetivo analisar as possibilidades de uso do ambiente virtual de aprendizagem (AVA) Planeta Rooda 2.0 por professores do ensino 
fundamental, com foco no desenvolvimento de projetos voltados a alunos que apresentam dificuldades de aprendizagem.

"Alfabetização e letramento: a produção de Histórias em Quadrinhos em ambiente informatizado", de Fabiana de Miranda Rocha, apresenta uma experiência desenvolvida com o uso de histórias em quadrinhos impressas e do software HagáQuê, para a criação de histórias por alunos de uma turma de $2^{\circ}$ ano de uma escola pública. Ao analisar a prática pedagógica envolvendo a produção de histórias em quadrinhos em ambiente informatizado, propõe-se a refletir sobre a potencialidade do uso dos recursos de laboratórios de informática para qualificar e significar a alfabetização e o letramento. Na sua argumentação, a aluna-docente-pesquisadora posiciona-se sobre os conceitos de alfabetização e letramento e recorre aos estudos de Vygotsky e Ausubel para embasamento sobre, respectivamente, o desenvolvimento das crianças e aprendizagens significativas.

"Leitura do jornal, leitura do mundo: reflexões sobre uma prática de letramento numa turma de alfabetização de jovens e adultos", de Bruna da Cunha Fagundes, que se embasou nas ideias de Paulo Freire, teve como enfoque pesquisar de que modos um projeto escolar, envolvendo o uso do jornal, contribui para a apropriação da língua escrita, a reflexão crítica de mundo e as práticas de letramento dos alunos de uma turma de alfabetização de jovens e adultos. A pesquisa participante envolveu a aluna-docente-pesquisadora em uma experiência de docência compartilhada com a professora titular de uma turma de Alfabetização de Jovens e Adultos (EJA) de uma escola da rede municipal de Porto Alegre, em uma proposta de realização de um projeto de letramento envolvendo o uso do jornal.

"'Caprichem nas folhinhas': a infantilização das práticas pedagógicas e a docência na EJA", de Márjori Bez Reus, trata-se de um estudo de caso em que a autora problematiza a infantilização das práticas 
pedagógicas na Educação de Jovens e Adultos (EJA) e propõe uma reflexão sobre os argumentos que justificam sua manutenção na escola. A aluna-docente-pesquisadora embasa suas posições na compreensão de letramento assim como é pensada por Leda Tfouni.

"Relações de gênero nos sites de jogos infantis: entre a beleza e a força", de Cristiane Luiza Abbud Flores, analisa as representações de gênero nos sites de jogos infantis disponibilizados na internet intitulados como Joguinhos de Menino e Joguinhos de Menina. A aluna-docente-pesquisadora busca entender como esses jogos reproduzem e impõem, implicitamente, determinados comportamentos, ditos como adequados e corretos, tanto para os meninos como para as meninas, ancorando-se na perspectiva teórica dos Estudos de Gênero e dos Estudos Culturais.

"Eu não escuto nada, só vejo: narrativas sobre 'ser surdo' e a educação bilíngue", de Priscila de Abreu Bortoletti, analisa, nas produções culturais surdas, as narrativas sobre "ser surdo" e sua relação com a construção da educação bilíngue. Trata-se de uma pesquisa documental que envolveu descrição e análise de narrativas em Língua Brasileira de Sinais (Libras), produzidas por acadêmicos do curso de Letras-Libras.

"Sentidos da escola para os jovens e adultos surdos", de Simone de Brum, enfoca alguns sentidos da escola para determinados jovens e adultos surdos e procura melhor conhecer aspectos da cultura e da comunidade surda. Foram realizadas entrevistas semiestruturadas com três alunos surdos de turmas de educação de jovens e adultos, de uma escola de Porto Alegre. Na sua argumentação, a aluna-docente-pesquisadora recorre ao campo dos Estudos Surdos.

As três pesquisas que compõem a Parte 2 deste livro privilegiam as propostas curriculares. As alunas-docentes-pesquisadoras escolheram temas contemporâneos nas discussões sobre os currículos escolares. 
Expõem problematizações que podem colaborar nos debates sobre a implementação e acompanhamento dessas ações.

"Práticas avaliativas e progressão continuada na rede municipal de Eldorado do Sul/RS: a ênfase está nas aprendizagens dos alunos?", de Juliana Hass Massena, estuda a progressão continuada da rede municipal de ensino de Eldorado do Sul/RS, em especial os seus efeitos sobre as aprendizagens dos alunos. Trata-se de estudo investigativo que teve como objetivo central problematizar práticas de avaliação adotadas por professores da rede, analisando suas concepções sobre as finalidades dos anos iniciais do ensino fundamental e o significado do processo de aprendizagem de seus alunos.

"(Re)Conhecendo o povo Mbya Guarani: um olhar para os kyringue", de Andréia Rosa da Silva Kurroschi, apresenta a temática indígena, direcionando o olhar para os kyringue do povo Mbya Guarani da Tekoa Anhetengua, do bairro Lomba do Pinheiro, município de Porto Alegre/RS, especificamente as crianças que frequentam $3^{\circ}$ e $4^{\circ}$ anos da escola indígena da aldeia. A investigação ancorou-se nas seguintes questões: quem são as crianças Mbya Guarani da Tekoa Anhetengua? Com o que se ocupam? O que fazem e o que mais gostam de fazer? Como é sua relação com a escola? Trata-se de pesquisa qualitativa, de cunho etnográfico, que buscou, na convivência com a comunidade e posteriores anotações do diário de campo, subsídios para descrever as crianças Mbya Guarani e suas relações com a escola.

"Capoeira Angola na escola: uma alternativa à formação integral dos estudantes", de Viviane Malheiro Barbosa, trata da dimensão educativa da capoeira Angola, visando à implementação da lei 10.639/03, ao considerar, em sua abordagem, que o estudo sobre o tema e seus fundamentos tem uma contribuição específica para a formação integral dos sujeitos no contexto escolar. A aluna-docente-pesquisadora procura expor contribuições que corroborem na prática e no estudo da capoeira 
Angola na escola, como possibilidade emancipatória para crianças, jovens e adultos, tendo como fundamentos seu estudo e sua experiência na capoeira. Foram realizadas entrevistas com três mestres da arte.

As três pesquisas que compõem a Parte 3 deste livro abordam a formação docente, sinalizando que, ao entender melhor os processos de docência, é possível exercê-la melhor.

"Pedagogia de Projetos: depoimentos de estagiárias de Pedagogia", de Catarine Machado Costa, produz uma reflexão, a partir de um estudo de caso, sobre como as alunas-estagiárias do curso de graduação em Pedagogia da UFRGS vivenciaram a prática da Pedagogia de Projetos. Foram realizadas entrevistas semiestruturadas com alunas do curso de Pedagogia da UFRGS que, assim como a autora, realizaram seus estágios no segundo semestre de 2012 em escolas da rede pública de Porto Alegre. Embasa suas posições sobre projetos de trabalho em Fernando Hernández e Josette Jolibert.

"O que ensinam os Estágios de Docência? A formação docente no curso de Pedagogia da UFRGS", de Lidiane da Silva Machado, problematiza a formação docente para a educação infantil e anos iniciais do ensino fundamental ao analisar as propostas dos Estágios de Docência oferecidas na sétima etapa do curso de Pedagogia/UFRGS. $\mathrm{O}$ estudo de caso apoiou-se na análise de conteúdo de relatórios de estágio de quatro alunas do curso de Pedagogia que realizaram seus estágios nas diferentes modalidades oferecidas e também em entrevistas semiestruturadas com as autoras dos relatórios para complementação dos dados. Ainda, foram analisados documentos do curso. Na sua argumentação, a autora recorreu às proposições de Maurice Tardif e Philippe Perrenoud.

"Memórias da formação: aprendendo a conhecer e a ser aquela que ensina e aprende", de Isaura Teresinha Silva Barbieri, apresenta uma 
narrativa autobiográfica, expondo medos e incertezas no processo de formação docente.

Tomara que estas catorze pesquisas sejam colaborativas ao inspirar o professorado para exercer a prática da pesquisa na docência em classes de educação infantil e anos iniciais do ensino fundamental!

As organizadoras 
Parte 1 Alunos em foco 


\section{As dificuldades de aprendizagem de Vítor: aprofundando seus fatores $e$ buscando possiveis soluções Angela Cristina Sthamer Gieseler}

Este trabalho consiste em um estudo de caso desenvolvido com um aluno do $4^{\circ}$ ano do ensino fundamental, de uma escola municipal de Novo Hamburgo, que apresentava dificuldades de aprendizagem nas áreas de leitura e de escrita. $\mathrm{O}$ acompanhamento desse aluno foi iniciado no primeiro semestre de 2012, para a disciplina de Psicopedagogia, do curso de Pedagogia na Universidade Federal do Rio Grande do Sul, e aprofundado no meu Trabalho de Conclusão de Curso (TCC), em 2013. O estudo teve como objetivo investigar os fatores que podiam estar causando/agravando tais dificuldades e auxiliar o menino a superá-las por meio de ações psicopedagógicas planejadas e desenvolvidas com ele. Como forma de coleta de dados, foram realizadas observações da rotina escolar, além de entrevistas com a professora titular, com o aluno e seus pais.

Neste artigo, apresentarei uma breve explicação das diferenças entre dificuldades de aprendizagem e transtornos como também farei referência à diversidade de fatores que podem influenciar 
estas dificuldades. Em seguida, o leitor poderá conhecer o "caso Vítor"1 e seus fatores externos (escola + família) e internos (entrevista + par educativo), terminando a minha exposição com o planejamento e a implementação da Ação Psicopedagógica e as considerações finais.

\section{DIFICULDADES $X$ TRANSTORNOS}

As dificuldades de aprendizagem são resultantes de diversos fatores e apresentam diferentes escalas de intensidade ou gravidade. Para que as crianças com dificuldades recebam as intervenções corretas, é preciso que se identifique, da forma mais precisa possível, o nível ou a categoria das dificuldades. Segundo os Parâmetros curriculares nacionais, essas dificuldades incluem "desde situações leves e transitórias que podem se resolver espontaneamente no curso do trabalho pedagógico até situações mais graves e persistentes que requerem o uso de recursos especiais para a sua solução" (Brasil, 1998, p. 33).

Muitas vezes, as crianças apresentam apenas algo transitório, "oscilações no rendimento escolar relacionadas a aspectos evolutivos do aluno ou decorrentes de metodologia inadequada, de padrões de exigência da escola, de falta de assiduidade do aluno e de conflitos familiares eventuais" (Moojen; Dorneles; Costa, 2003, p. 108), estando presente apenas em uma determinada etapa de sua escolarização e se tratando de algo que, com um trabalho pedagógico direcionado e complementar, estará solucionado. Para que essas manifestações sejam superadas, como explica Corso (2008), o apoio da escola e da família é fundamental.

Todavia há casos em que também se pode estar diante de uma dificuldade severa ou até mesmo de um transtorno. Ao falarmos de transtornos, convém assinalarmos que a Organização Mundial da Saúde (1993) os define como "comprometimentos específicos e significativos

\footnotetext{
${ }^{1}$ Para preservar a privacidade do aluno foi utilizado um nome fictício.
} 
no aprendizado de habilidades escolares" (p. 237), sendo que as crianças com transtornos de aprendizagem apresentam dificuldades mais persistentes que não são completamente curáveis, mesmo com um trabalho mais direcionado, ou seja, estas dificuldades acompanharão o aluno sempre, não apenas na infância e adolescência, mas por toda a vida (Moojen, 1999).

Em função de a dificuldade de aprendizagem ser algo bastante complexo, que envolve diversas testagens e a investigação de todos os fatores determinantes do desempenho escolar, cabe a um profissional especializado dar o seu diagnóstico. Devem-se evitar, a qualquer custo, os diagnósticos precipitados, os quais muitas vezes acabam rotulando a criança precipitadamente.

\section{CUBO DE SYRACUSE: A DIVERSIDADE DE FATORES QUE PODEM INFLUENCIAR NAS DIFICULDADES DE APRENDIZAGEM}

O Cubo de Syracuse é uma ótima representação desenvolvida por Corine Smith (1986, apud Golbert; Moojen, 1996, p. 85) para mostrar os fatores responsáveis pelas dificuldades de aprendizagem. Quando observamos um cubo, nós o vemos como um todo, dado que não olhamos para um dos lados isoladamente, mas sim para o conjunto. Por isso, ele é uma representação perfeita das dificuldades de aprendizagem, que também devem ser vistas de uma forma global, já que são diversos os fatores - diversas faces do cubo - que podem causá-las.

Para que se possam compreender melhor esses fatores etiológicos, tão relevantes no desempenho escolar, é importante compreender cada uma das suas faces. 


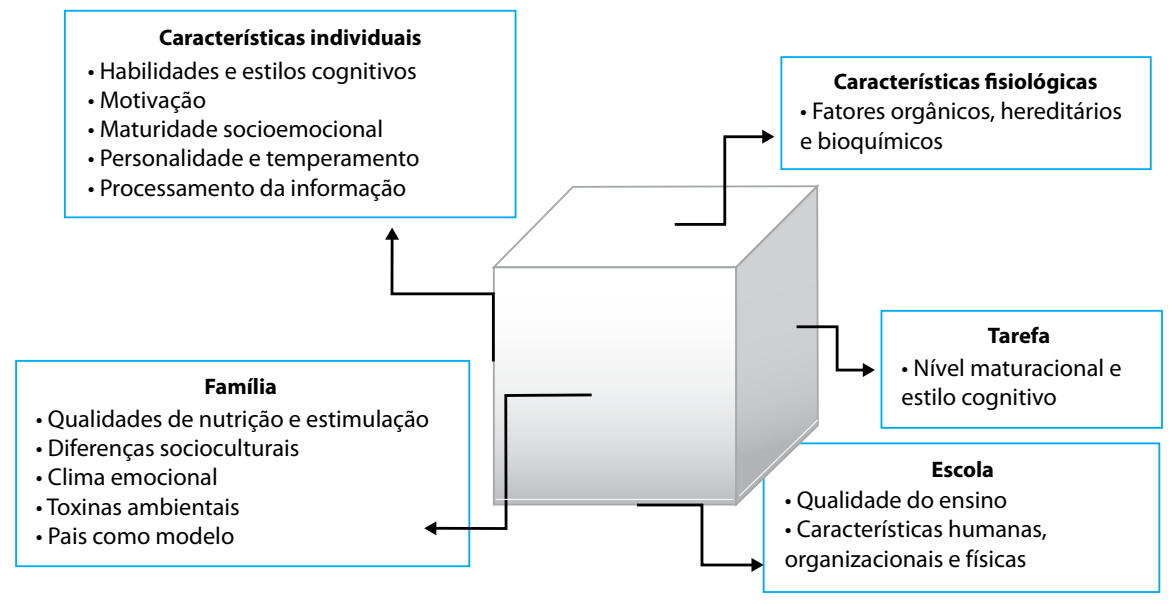

Figura 1 - Cubo de Syracuse

De acordo com Golbert e Moojen (1996), a primeira face do cubo é a que, na verdade, representa o todo e a ele se refere. Ela é chamada fatores determinantes do sucesso ou fracasso escolar.

Outra das faces do cubo refere-se a fatores familiares. Dada a importância da família na vida de qualquer pessoa, é fácil perceber o quão relevante e decisiva ela pode ser no surgimento - ou no processo de aceitação/adaptação/superação - das dificuldades escolares de uma criança. Segundo Weiss (1997), com a sua experiência clínica com pacientes de diferentes classes sociais, foi constatado que por volta de $10 \%$ das crianças que apresentavam dificuldades e foram encaminhadas para diagnóstico psicopedagógico tinham na relação familiar e pessoal a causa das suas dificuldades.

Quando a família deixa de ser uma fonte de proteção para a criança e seu desenvolvimento psicossocial, pode ocorrer o início de uma dificuldade de aprendizagem. Por isso, é essencial que os pais avaliem sempre como os seus filhos se sentem no meio familiar, se este pode ser considerado um ponto de referência, amor e segurança ou se está 
exercendo estresse na criança devido a discussões, desajustes e falta de interação entre pais e filhos.

Os fatores biológicos, outra das faces do cubo, abrangem os aspectos orgânicos, hereditários e bioquímicos. Do mesmo modo que os fatores do meio - como os familiares recém-abordados -, os fatores do organismo exercem uma importante função no surgimento de dificuldades de aprendizado. Por isso, cabe resaltar a importância de se investigar como está a saúde em geral do paciente. Segundo Pain (1985), é de extrema importância que se façam exames de audição e visão, pois crianças que apresentam algum problema nessas áreas podem ser vistas como "o que não quer ler, ou ouvir".

Os fatores hereditários também podem exercer um papel importante no desenvolvimento intelectual, por isso é essencial que sejam analisados.

Os fatores relacionados à escola são considerados alguns dos mais decisivos no sucesso ou fracasso escolar de uma criança, pois é na escola que ela realiza descobertas voltadas ao letramento, à aritmética, dentre outras. Para que as crianças tenham êxito nestas aprendizagens, é fundamental que o ambiente seja acolhedor, estimulante, que seja adaptado à realidade cultural dos alunos e aos seus valores. Para isso, é necessário que o seu currículo seja adaptado, com conteúdos de qualidade e de verdadeira relevância para determinada região, cidade e realidade social. Caso contrário, as chances de ocorrerem dificuldades de aprendizagem, além de evasão escolar, são muito grandes.

Deve-se observar também a relação entre aluno e professor, que, quando problemática, pode propiciar o surgimento de dificuldades, já que ela influencia na motivação do aluno em fazer descobertas e aprender juntamente com a turma, além de afetar sua relação com o ensino.

A face do cubo relacionada às tarefas desenvolvidas na escola e sua relação com o desenvolvimento cognitivo e nível maturacional do aluno 
é, muitas vezes, subestimada. Porém seu valor é inquestionável. Como explica Corine Smith (1985, apud Golbert; Moojen, 1996, p. 90), "quanto maior a congruência entre as características da criança e as características do programa que lhe é previsto, maior é a probabilidade de sucesso escolar". Esse fator é determinante no desempenho escolar, já que muitos dos problemas e dificuldades surgem quando são oferecidas tarefas que não estão de acordo com as capacidades cognitivas das crianças. Por isso, é crucial que o professor saiba em que estágio de desenvolvimento os seus alunos se encontram, para que todos possam desfrutar da aprendizagem de acordo com as suas reais possibilidades.

A face referente às características individuais foi escolhida para ser a última analisada, pois, como Golbert e Moojen (1996) explicam, assim se evita rotular e colocar a responsabilidade do problema na criança precipitadamente. Ou seja, deve-se sempre analisar os outros aspectos e somente no final averiguar os fatores individuais da criança. Ao investigar as dificuldades de aprendizagem de uma criança, deve-se levar em conta a necessidade de observação do nível de motivação, a maturidade socioemocional, o funcionamento das suas estruturas cognitivas em diferentes áreas, além das características da personalidade e caráter, dentre outros fatores, como salientam esses autores.

Quando há falta de motivação em uma criança, podemos pensar em algumas questões causadoras, como a falta de determinadas habilidades cognitivas, que fazem o aluno se sentir "burro" e menos capaz do que seus colegas, o que naturalmente afeta a sua autoestima e, consequentemente, sua motivação em aula. Como se pode perceber, a busca da compreensão das causas da dificuldade de aprendizagem de uma criança não é, de forma alguma, simples, justamente por, muitas vezes, existir uma linha muito tênue entre as dificuldades e o que é considerado "normal". 


\section{O CASO VITTOR}

\section{Fatores externos}

\section{conhecendo a sua escola}

A escola em que Vítor estuda atende atualmente em torno de 350 alunos dos 5 aos 11 anos, da Educação Infantil ao quinto ano do Ensino Fundamental, em turno diurno. A maioria dos alunos é de classe média. Trabalham nesta escola em torno de 20 professores. O ambiente - tanto das salas quanto dos corredores - é colorido e alegre, limpo e organizado, bastante acolhedor. A sua biblioteca é muito agradável, sendo bastante visitada e disputada pelos alunos. A leitura é muito estimulada nesta escola, que também oferece vários projetos, como Judô, Dança, Monitores Ambientais, Xadrez, Repórter e Mídia, dentre outros.

Os profissionais da escola realizam práticas de formação continuada através de cursos subsidiados pela Secretaria Municipal de Educação, o que é essencial e considerado muito estimulante pelos professores com quem conversei. Por último, é interessante comentar que esta escola tem um número muito baixo de repetência, não chegando nem a cinco crianças por ano, além de o nível de evasão escolar ser literalmente nulo.

\section{conhecendo a sala e a turma em que vítor estuda}

Na sala de aula do Vítor, estudam 24 alunos, organizados em quatro colunas e sentados em duplas. Vítor está na segunda fileira localizada em frente ao quadro, sentado ao lado de sua colega Fabiana, uma menina que o trata muito bem, mostra-se inteligente e dedicada.

A forma de avaliação da professora é, segundo ela, "por meio de aspectos mais concretos, como trabalhos, leituras, avaliações escritas", mas ela também não deixa de levar em consideração a participação e o comportamento em aula. 
A atmosfera, em geral, parece bastante amigável. No entanto, nos momentos em que a turma está no recreio, na aula de biblioteca, na educação física, ou seja, em momentos fora da sala de aula e sem a professora titular, as coisas nem sempre são assim. Em relação ao Vítor, por exemplo, são visíveis a rejeição e o preconceito em atos e falas das crianças, que consideram que ele apresenta um "perfil feminino" (como foi definido por uma professora da escola), falando e andando de forma diferente da maioria dos meninos.

Nesses momentos, fora de sala de aula, Vítor sofre com a rejeição, pois, apesar de algumas crianças brincarem com ele, são vários os que não o querem por perto. Mas ele parece não se abalar com isso e continua correndo atrás deles. Em um dos recreios observei, por exemplo, que Vítor estava seguindo um destes meninos e, repentinamente, o abraçou, o que foi imediatamente respondido com chutes e xingamentos.

Em outro momento, durante a aula de biblioteca, a professora estava lendo um livro relacionado às diferenças, e a turma começou a rotular alguns colegas com as denominações trazidas pelo livro (como "o aluno quietinho", "o aluno bagunceiro" etc.). Vítor logo começou a ser chamado de "gay" e, como não quis demonstrar estar se abalando, entrou na brincadeira, chamando também outros colegas de outras denominações. Ele e outro aluno insistiram tanto na "brincadeira" que foram retirados da sala, e, ao falar sobre esse assunto em particular com a professora, Vítor demonstrou abertamente sua mágoa, começando a chorar.

\section{conhecendo a professora da turma do}

$4^{\circ}$ ano e a sua visão sobre vítor

A partir do que foi percebido ao longo dos cinco dias em que realizei observações nesta turma antes de começar o trabalho com o Vítor, concluí que a professora é uma profissional querida por todos e carinhosa, com o tom de voz bastante suave, trabalha com as crianças com 
tranquilidade, o que acaba influenciando o andamento da aula. ${ }^{2}$ Ela é também muito respeitada por todos.

As atividades/conteúdos sempre são propostos de forma questionadora e a sua realização é mediada pela professora - que frequentemente passa nas mesas para ver como estão sendo feitas as atividades. Neste ambiente, a participação dos alunos é promovida e favorecida em quase todos os momentos: eles podem colaborar com seus conhecimentos prévios, além de terem a oportunidade de mostrar seus saberes sobre 0 conteúdo em andamento através de leitura e visitas ao quadro-negro. Em todos estes momentos percebi, ao longo das minhas observações, que a professora procura motivar e elogiar quando há o acerto e, quando há um erro, tenta encontrar, em conjunto com a turma, a resposta correta. Por já ter sido professora desta turma no primeiro ano, a cumplicidade entre professora e alunos é muito grande. Notava-se o afeto tanto dos alunos quanto da professora.

Realizei uma entrevista com ela, na qual foram feitas algumas perguntas relacionadas a ela, mas o foco foi o Vítor. Enquanto conversávamos, fui transcrevendo suas respostas em meu notebook. Merecem destaque os seguintes aspectos assinalados por ela:

- segundo o ponto de vista da professora até aquele momento, as maiores dificuldades de Vítor estavam relacionadas ao convívio com o grupo, à aceitação por parte deles;

- por já ter sido professora de Vítor no primeiro ano, ela conhece os pais dele e mantém contato com eles;

- o aluno é bastante participativo, acompanha o ritmo dos demais e não tem vergonha de falar ou tirar suas dúvidas;

\footnotetext{
2 Além do que observei das aulas para este trabalho, também fui sua aluna durante dois anos na época em que estudei nesta escola, por isso conheço bem suas características em sala de aula.
} 
- fragilidades: leitura - lê sem ritmo - e a questão emocional, não parece saber lidar com a questão de identidade;

- o que consegue fazer bem: ele tem muitas qualidades, faz cálculos bem, copia com a letra bonita e o caderno é caprichado, faz desenhos criativos, é carinhoso etc.;

- aulas de reforço de matemática e português: devido aos horários colidirem com o de um projeto extraclasse que ele estava realizando, ele não as estava frequentando;

- a respeito do "jeito feminino": a professora tem a impressão de que ele age daquela forma por querer aparecer, pois faz também muitas palhaçadas. Ela acredita que ele não saiba lidar com os seus sentimentos e que, por isso, tenta sempre se mostrar para os outros, querendo ser observado, visto por todos, o que acabava causando um certo preconceito por parte de muitos alunos da turma;

- apesar de todo o preconceito, Vítor não demonstrava, em momento algum, abalar-se com os apelidos e exclusões, aparentando estar sempre feliz. Ela acredita que isso seja uma forma de se proteger.

\section{Conhecendo um pouco do meio familiar de Vítor}

Marquei uma reunião com os pais de Vítor, mas apenas a mãe compareceu. Segundo ela, o pai não pôde estar presente por não ter possibilidade de faltar ao trabalho. A anamnese com a mãe do aluno ocorreu como uma espécie de conversa, com breves anotações minhas em uma folha. Além disso, com o auxílio da gravação da sua voz, pude transcrever da melhor forma a entrevista. Ao longo desta conversa, percebi muitas questões de grande importância para este trabalho:

- tanto a gravidez quanto o período de bebê do Vítor foram bastante tranquilos;

- Vítor é independente com a higiene pessoal e bastante organizado com os afazeres domésticos e da escola; 
- quando bebê, não teve nenhum medo/insegurança quando começou a caminhar, descer escadas etc.;

- o garoto e sua mãe são bem próximos, brincam bastante juntos;

- em casa, Vítor gosta de brincar com a sua cachorrinha e andar de bicicleta, em geral é bastante sossegado, gosta de atividades mais calmas como desenhar, folhear livros, pintar etc.;

- continua dormindo com os pais às vezes, mesmo estando com 10 anos;

- alfabetizou-se no $2^{\circ}$ ano do ensino fundamental - dizendo, àquela época, que "agora não podia mais brincar";

- sobre o pai: segundo a mãe, ele é “quietão”. Quando Vítor ingressou na escola, na educação infantil, prometeu a ele uma bicicleta se ele não chorasse;

- sobre a mãe: ficava muito tempo longe por causa do trabalho, até os 2 anos de vida do Vítor, ele ficava com a avó;

- durante a cesárea, no nascimento do Vítor, os médicos cortaram acidentalmente a bexiga de sua mãe, o que impossibilitou que ela ficasse com o filho e o amamentasse, já que ficava mais tempo no hospital do que em casa. Ela só pôde começar a cuidar normalmente dele após 4 meses. Neste meio tempo, quem mais ficou com ele foi sua avó, já que o seu marido trabalha o dia todo.

\section{Fatores internos}

\section{Refletindo sobre o que mudou entre um ano e outro}

Esta subseção aborda as principais diferenças notadas ao comparar as duas entrevistas realizadas com Vítor, uma em 2012 e a outra em 2013, com intervalo de um ano.

Na primeira pergunta feita ao Vítor - "Quais são as coisas que mais gostas de fazer?” -, obtive, nas duas vezes (2012 e 2013), a mesma resposta: 
“Estudar matemática!”. Percebi que o estudar - em geral - é muito importante para ele, algo a que dá prioridade. Como foi comentado ao longo da entrevista com a mãe, o garoto é bastante organizado a respeito dos estudos.

Um dado muito interessante é que, em 2012, Vítor relatou que o que mais gostava de fazer eram cálculos de adição e subtração, sendo que, naquela época, ele tinha grandes dificuldades em matemática. Com a ajuda da sua psicopedagoga, enfrentou essas dificuldades e na segunda entrevista (2013) estava se saindo muito bem, obtendo nota 80 na sua última prova. Isso é motivo de grande orgulho e felicidade para ele, algo que ele deixa transparecer quando fala sobre o assunto.

Ao questioná-lo quanto ao "O que é legal e o que não é legal na escola e por quê?", novamente as respostas foram as mesmas nos dois anos. No entanto, em 2013 ele acrescentou que não achava legal que os colegas o chamassem de gay e utilizassem outros apelidos pejorativos; o que antes, no ano anterior, já o incomodava, mas não o suficiente para ser exposto na entrevista, desta vez teve destaque. Vítor acrescentou ainda que isto o deixa muito chateado.

Na questão “O que é fácil e o que é difícil na escola?”, ele considerou a prova algo bastante difícil nos dois anos, isso porque, segundo Vítor, ela sempre contém perguntas difíceis. Um fator muito interessante está relacionado à sua resposta quanto a algo considerado fácil para ele porque ele estabelece uma associação com a matemática (em 2012) e com a leitura (em 2013), sendo que estas foram consideradas, pelas respectivas professoras, suas maiores dificuldades.

Ao ser questionado quanto ao "que ele faz quando tem dificuldades na escola", houve novamente uma grande diferença entre um ano e outro. Em 2012, Vítor explicou que, quando tinha dificuldades em sala de aula, não pedia ajuda à professora, tentava solucionar seus problemas sozinho. Na época, outros dois alunos da mesma turma deram respostas 
semelhantes. Acredito que isso se devesse ao fato de esses alunos terem medo de questionar a professora da época, que, apesar de não recriminar a turma ao tirar suas dúvidas, aparentava ser mais séria, o que talvez fosse o motivo de maior receio por parte dos alunos. Já na última entrevista, em 2013, relatou buscar auxílio da professora Angela e que, quando ele busca essa ajuda, ela sempre responde de forma muito calma e tranquila, com exceção dos dias em que estão em provas, caso em que ele tem de achar as respostas sozinho. Quanto à questão "O que é ser bom aluno para ti?", também houve algumas diferenças. Em 2012, ele explicou que um bom aluno é aquele que "é educado e tem amor pelos outros", não enfatizando tirar notas boas ou algo nesse sentido. Já em 2013, Vítor realçou as suas próprias qualidades: “ser estudioso, gostar de fazer o tema, participar e não ficar 'fazendo cara feia' para o que a professora pede".

Para finalizar a entrevista, questionei "O que queres ser quando crescer?". A resposta foi imediata, "PROFESSOR!", assim como no ano anterior. Este seu desejo vem acompanhando-o. Parece ser algo que realmente ele deseja. Ao perguntar acerca da matéria que gostaria de lecionar, ele respondeu que não tinha nenhuma predileção, que gostaria de ser "professor de qualquer matéria, desde que professor".

Acho que essa vontade de seguir essa carreira vem justamente de querer provar que ele é inteligente e capaz, da vontade de estar de volta à escola, mas, dessa vez, no papel de um professor, com o intuito de ajudar outros alunos, de mostrar sua capacidade e seus conhecimentos.

\section{Par Educativo - 0 que os}

\section{desenhos do vítor demonstram}

$\mathrm{Na}$ segunda parte da entrevista realizada com Vítor, propus uma atividade denominada Par Educativo, um teste projetivo gráfico muito importante na avaliação psicopedagógica. Segundo Gola (1999, p. 55), “as técnicas projetivas nos aproximam do funcionamento psíquico 
do sujeito, facilitando o acesso a conteúdos inconscientes. A projeção nos conduz ao conhecimento do que não é dito abertamente". Este teste funciona da seguinte forma: solicita-se que a criança desenhe uma pessoa que aprende e uma que ensina, sugerindo, a seguir, que ela formule uma história oralmente ou por escrito envolvendo esses dois personagens, dando nome e idade aos mesmos. É possível, por meio disso, interpretar as concepções da criança acerca das relações ensinante-aprendente, do papel vivido na escola, em turma, de possíveis rejeições às situações escolares etc.

Comparando o primeiro Par Educativo, produzido por Vítor em 2012, com o seguinte, em 2013, algumas características se mantiveram, e novas questões surgiram. Ao observar os dois desenhos, solicitados com um ano de intervalo, percebi que, tanto no primeiro quanto no segundo desenho, o garoto representou uma sala de aula com um professor e um aluno (ver Imagens I e II).

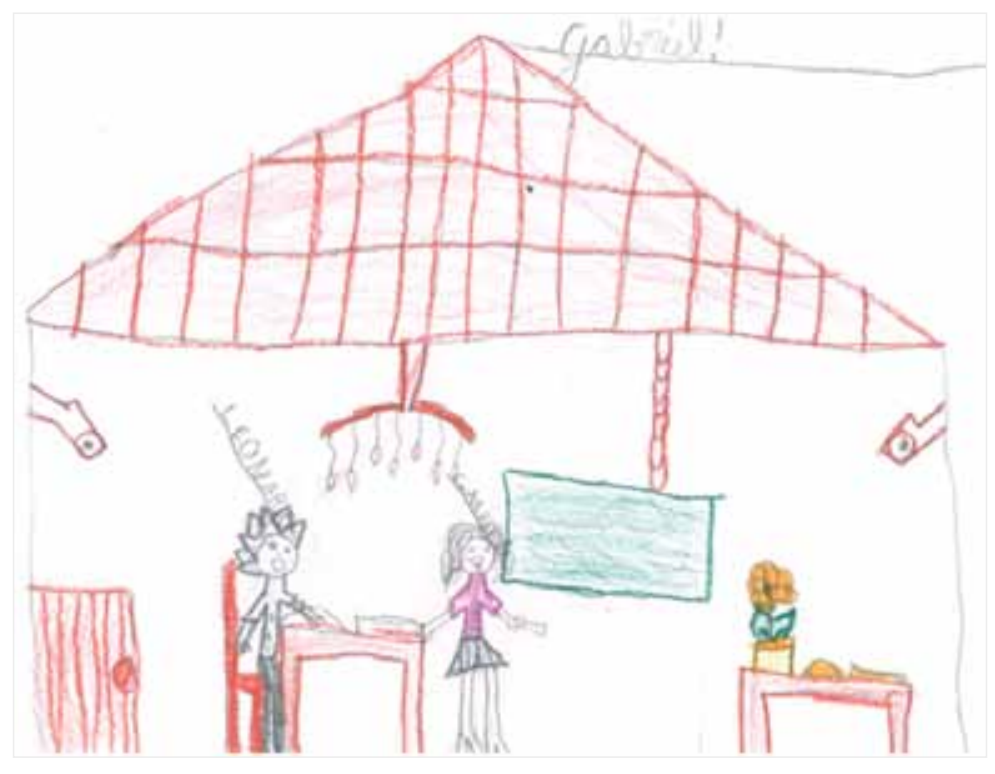




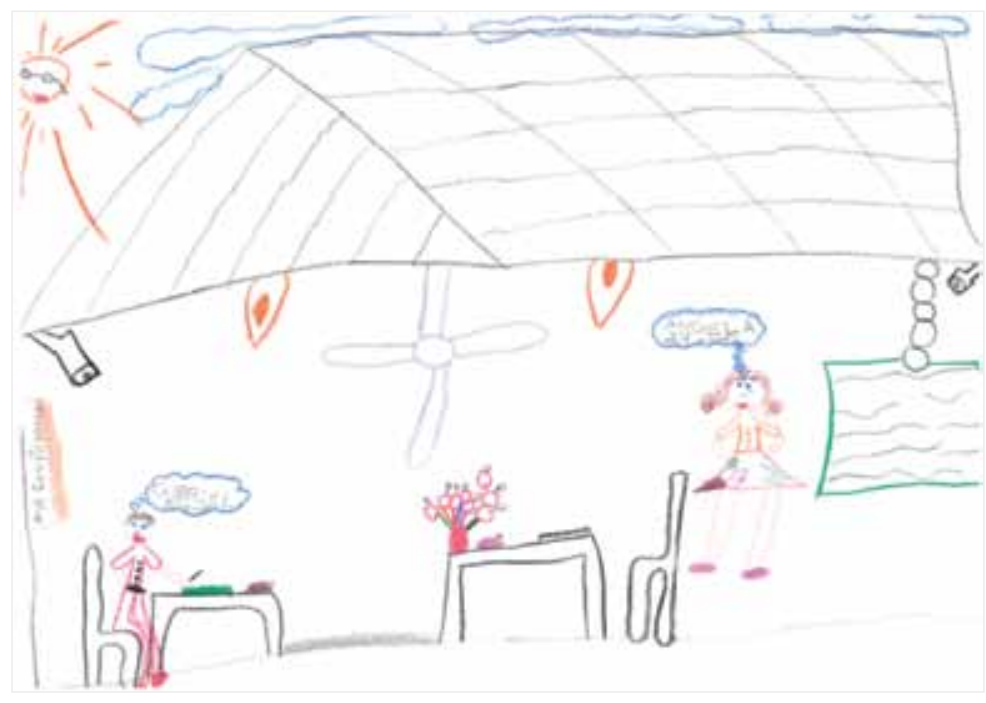

Imagens I e II - Par Educativo de uma pessoa que ensina e outra que aprende, produzidos por Vítor nos anos de 2012 e 2013, respectivamente.

Fonte: Arquivo da autora.

No primeiro desenho, a mesa do professor ficava em um canto da sala, e a do aluno, no outro lado. No entanto, mesmo a mesa do professor estando distante da mesa do aluno, ele se encontrava parado ao lado do seu aprendiz, auxiliando-o. Já no segundo desenho, as mesas estão mais próximas, no entanto o professor não está mais ao lado do aluno, e sim mais próximo do quadro. Essas representações nos permitem inferir que, antes, o aluno precisava de alguém mais próximo, auxiliando-o constantemente, depois ele não precisava mais de tanta proximidade, o que faria sentido no panorama de 2013, em que Vítor já conseguia lidar melhor com algumas de suas dificuldades.

É importante ressaltar que, no momento em que o segundo Par Educativo foi proposto, Vítor havia se saído muito bem na primeira prova aplicada naquele ano, relacionada unicamente a cálculos matemáticos, 
em que obteve nota 80 . Acredito que essa nota possa ter influenciado na representação de uma independência aparentemente maior do aluno nesse desenho.

Uma das grandes diferenças evidenciada nos dois desenhos está relacionada às cores utilizadas. No primeiro, houve a predominância de cores mais quentes - vermelho e rosa, criando uma atmosfera aparentemente inquieta. Já no segundo, tudo estava mais alegre, porém aparentemente mais calmo, com o uso de várias cores diferentes, tais como rosa, azul e verde. Isso nos permite ponderar que, talvez, na época do primeiro desenho, o aprendizado fosse algo bastante difícil para o aluno. Já no segundo desenho, tudo parece estar mais leve, mais alegre, sendo possível especular que ele, nesse momento, vê a aprendizagem de forma mais natural.

Quando solicitei que Vítor escrevesse sobre o que estava se passando na época do primeiro desenho, ele disse: "Era uma vez um escola buitu bonita e nela tinha uma profesora que imsinava um aluno que tinha 8 anos!". ${ }^{3}$ É interessante atentarmos para o fato de que ele não disse que "o aluno aprendia", enfatizando apenas que "o professor ensinava", contraste que podemos notar de forma mais nítida ao lermos a explicação dele para o segundo desenho, em que escreveu que: "Essa história o Vítor esta aprende coisas sopre matematica com a Angela e ela estava esplicando pra ele". ${ }^{4}$ Nesse desenho, percebe-se o aprendente como sendo a representação do próprio Vítor, que adora matemática e estava se saindo muito bem até então (primeiro semestre de 2013).

No primeiro desenho, o aluno representado foi chamado de Leonardo - ex-colega de Vítor que também tinha dificuldades de aprendizagem - e a professora, Gabriela - uma vizinha de quem ele

${ }^{3}$ Tradução: "Era uma vez uma escola muito bonita e nela havia uma professora que ensinava um aluno que tinha 8 anos!".

${ }^{4}$ Tradução: "Nesta história, o Vítor aprende coisas sobre matemática com a Angela, e ela estava explicando para ele". 
gostava muito. Já, no segundo desenho, Vítor representou a si mesmo no menino que estava aprendendo e chamou de Angela a professora que o estava ensinando. ${ }^{5}$

O que chama muito a atenção na representação de sala de aula dos dois desenhos realizados no Par Educativo é que, em cada um, há duas câmeras filmando, como as que existem nas entradas de prédios câmeras de segurança. Essas câmeras surgiram também em outros desenhos que ganhei dele ao longo das duas semanas que estive com esta turma em 2012 e, também, depois, em 2013, quando apareceram em desenhos feitos em dois trabalhos solicitados pela professora titular. Considerando que estes outros desenhos retratavam ambientes externos à escola - o quarto de Vítor, a natureza, um passeio feito pela cidade - e que, mesmo assim, estes objetos se encontravam presentes, seja escondidos na grama, seja na parede do lado de fora da casa, na parede do quarto etc., penso que eles podem representar a sensação de ser vigiado constantemente, não apenas pelos professores, devido às suas dificuldades de aprendizagem, mas também pelos seus colegas de aula que o rotulam e o chamam por nomes pejorativos.

\section{AÇÃO PSICOPEDAGÓGICA}

\section{Planejamento}

A partir de todas as entrevistas, observações e reflexões feitas até o início do planejamento das intervenções psicopedagógicas, percebi que Vítor vinha obtendo grandes avanços em relação às suas dificuldades anteriores em cálculos matemáticos, o que nitidamente lhe trazia grande

\footnotetext{
${ }^{5}$ Neste momento, indaguei ao Vítor a qual professora ele se referia: à professora titular da turma dele ou a mim, já que ambas temos o mesmo nome. Obtive como resposta que era a mim, no entanto, não há como saber exatamente se foi realmente a mim que ele queria representar ou se esta resposta foi-me dada apenas para não correr o risco de me deixar triste.
} 
orgulho. Este avanço se devia principalmente à sua psicopedagoga, com quem Vítor fazia um acompanhamento semanal e que lhe auxiliou a avançar e superar parte dessas dificuldades. Segundo sua mãe, ele tinha uma espécie de "bloqueio", que não permitia que fosse adiante.

No entanto, algumas dificuldades ganharam maior destaque no início de 2013, como a sua leitura em voz alta, pausada demais, a interpretação de histórias matemáticas - questão comentada pela professora - e, ainda na área da escrita, as trocas "surdas sonoras" $P / B, C / G$ e $J / G->$ $\mathrm{CH} / \mathrm{X}$, ainda que apenas ortograficamente, não na fala.

Conforme já abordado, outro fator que estava mais presente em 2013 do que no ano anterior e que incomodava bastante o Vítor dizia respeito ao preconceito que ele vinha sofrendo por parte de seus colegas de escola. Ele era insultado e ironizado de forma frequente, principalmente nos momentos em que os professores não estavam presentes.

Ao refletir sobre quais intervenções poderiam ser realizadas com esse aluno, eu tinha como objetivo realizar atividades cujo foco fosse suas principais dificuldades escolares, mas trabalhando concomitantemente para ajudá-lo com sua autoestima. $\mathrm{O}$ aumento desse sentimento se revelava um fator central para que ele conseguisse lidar melhor não apenas com o preconceito que sofria com tanta frequência, mas também com uma possível angústia reprimida - por se perceber diferente dos colegas - e com a frustração - que suas próprias dificuldades na escola podem causar. Para atingir tais objetivos, realizei 10 sessões de 45 a 60 minutos cada, as quais serão discutidas no item a seguir.

\section{implementação}

$\mathrm{Na}$ implementação desta ação psicopedagógica, houve três focos principais no que se refere ao âmbito escolar: o trabalho com a dificuldade relacionada à troca entre surdas e sonoras; a questão da produção 
e interpretação de textos; e o trabalho ligado à matemática, com a interpretação de historinhas matemáticas e o treino da tabuada.

Nas primeiras sessões, ligadas às trocas entre surdas e sonoras, foram propostas atividades como o Instrumento de Avaliação Sequencial de Consciência Fonológica (Confias), que foi utilizado para propiciar a reflexão do aluno sobre os sons das palavras, dado que possibilita que ele escute fonema por fonema e, assim, perceba algumas diferenças entre sons surdos e sonoros. Em seguida, foi feito um trabalho mais profundo sobre essas trocas, o qual foi embasado no livro A escrita ortográfica na escola e na clínica, de Sônia Moojen (2009). Para finalizar essa questão, foram realizados exercícios de sistematização das diferenças entre surdas e sonoras para verificação das aprendizagens.

Nas sessões ligadas à produção e interpretação de textos, trabalhei o livro Duas dúzias de coisinhas à toa que deixam a gente feliz, de Otavio Roth (2000), que culminou na criação de um livro próprio inventado por Vítor. Nas últimas sessões, solicitei a ele a escrita de um texto que trabalhasse mais um pouco suas habilidades de escrita e sua imaginação, o qual deveria ser feito sozinho em casa e cujo tema foi "Como será o mundo daqui a 20 anos?”.

No que se refere às sessões ligadas à matemática, o foco foram as atividades sobre representação de quantidades, interpretação de historinhas matemáticas e tabuada.

\section{CONSIDERAÇÕES FINAIS}

Quando, neste trabalho, optei por dar continuidade ao estudo de caso sobre dificuldades de aprendizagem que havia iniciado em 2012, estipulei como meu principal objetivo tentar auxiliar o Vítor a buscar o caminho para solucionar algumas de suas dificuldades. Este auxílio não passava apenas por questões pontuais em português, leitura ou 
matemática, mas também por um trabalho cuidadoso relacionado ao fortalecimento de sua autoestima.

A questão do preconceito que o aluno vinha enfrentando, por se mostrar um pouco diferente da maioria dos seus colegas meninos, parece ser o fator que mais influência exerceu na sua baixa autoestima. Foi possível perceber, ao longo do meu trabalho com ele, que este não era o único fator causador das dificuldades de aprendizagem que ele apresentava, mas não podemos ignorar a possibilidade de isso ter influenciado ou colaborado em certo grau para o agravamento de suas dificuldades. Concordo com Lemos (2007, p. 73) quando pontua que: “[...] de acordo com as teorias psicopedagógicas, o bullying ${ }^{6}$ é considerado um dos atuais causadores de problemas de aprendizagem, visto ser capaz de desarmonizar as dimensões cognitiva, simbólica, orgânica e corporal".

Creio que o Par Educativo e a Ação Psicopedagógica o ajudaram bastante. O Par Educativo foi um ponto de entrada muito importante, já que, através de atividades lúdicas como esta, as crianças expõem seus sentimentos e preocupações, e é nestes momentos que ficam visíveis questões inconscientes.

Através da implementação da Ação Psicopedagógica, conseguimos alcançar ótimos resultados na área da escrita, tanto em termos de produção textual quanto no que se refere às trocas entre surdas e sonoras que ele apresentava. Ao término de meu trabalho, ele continuava realizando pequenas trocas, no entanto com uma frequência muito menor. As suas dificuldades em interpretação de histórias matemáticas mostraram que seus problemas não estavam apenas na área da interpretação, mas também em fatores que são pré-condições para ela, como a tabuada. Apesar de não ter sido o foco de meu trabalho com o Vítor,

\footnotetext{
${ }^{6}$ Segundo, Lemos (2007, p. 69), “bullying é um fenômeno de agressão velada, física, verbal ou psicológica, capaz de acarretar enorme prejuízo emocional, psicológico e social no indivíduo vitimizado".
} 
houve algumas melhoras nesta área, e acredito que, se isso continuar sendo trabalhado com o aluno, há muitas chances de que ele evolua ainda mais nesse sentido.

Quanto ao Vítor e à sua professora, esta experiência deixou ainda mais clara, para mim, a importância de uma boa relação entre o ensinante e o aprendente. A relação entre ambos é realmente muito boa, algo que claramente tinha grande impacto em sua aprendizagem e em seu bem-estar em sala de aula.

A escola em si também é muito participativa e consciente. Partiu da coordenação pedagógica, juntamente com a equipe diretiva, a ideia de que Vítor buscasse o apoio especializado de uma psicopedagoga e, quando expliquei que o foco do meu TCC seria ajudar este aluno, fui muito bem recebida pela coordenação e direção.

Ainda assim, considerando a complexidade dos fatores envolvidos na situação do Vítor com seus colegas, percebo que há outras ações que a escola poderia realizar para ajudar não apenas este aluno, mas outros também, pois tratar da tolerância do ser humano ao que é diferente é um dos fatores básicos da construção da cidadania. Trata-se de uma questão crucial que deve ser trabalhada já na infância, considerando que esta é uma etapa da vida em que o indivíduo está formando sua personalidade, com seus gostos e costumes. Além disso, ao comparar a entrevista realizada com a professora de 2013 com a que eu havia feito com a professora do ano anterior, percebi que não parecia haver um contato entre as professoras titulares e os profissionais especializados que estavam trabalhando em determinados casos de alunos, como o de Vítor e a sua psicopedagoga. Isso realmente é uma pena, pois, se houvesse uma comunicação entre elas, seria muito mais fácil a busca de respostas para as dificuldades de aprendizagem dele e de outros alunos. Observei que a coordenadora da escola faz visitas à psicopedagoga de tempos em tempos, no entanto, acredito que seria ainda 
mais importante a professora e a profissional estabelecerem uma troca de informações constante, o que facilitaria esse trajeto para ambas as partes e, principalmente, ajudaria mais o aluno.

Outro fator que foi surgindo ao longo do meu trabalho com o Vítor e que exige atenção está relacionado aos mecanismos de defesa a que ele parecia recorrer para não se deixar abalar pelas dificuldades que vinha sofrendo, tanto em termos escolares quanto em termos de relacionamento com os colegas. Aparentemente, estes problemas não abalavam o seu "alto astral", já que ele se mostrava sempre muito alegre e disposto a ajudar. Mas este "estar sempre muito alegre", inclusive nos momentos em que era alvo de gozações, e o fato de dizer que considerava fáceis as disciplinas nas quais ele, na verdade, apresentava mais dificuldades nos permitem imaginar que isso fosse apenas um mecanismo de defesa dele, já que o “[...] método de negação, no qual se baseia a fantasia de inversão dos fatos reais nos seus opostos, é empregado em situações em que é impossível evitar uma impressão dolorosa externa" (Freud, 1968, p. 105), sendo que estes mecanismos constituem operações de proteção do ego para assegurar a própria segurança do indivíduo. Freud (1968, p. 92) explica ainda que

[...] o método pelo qual a "dor" e a ansiedade objetivas são evitadas é muito simples. O ego da criança recusa-se a tomar conhecimento de uma certa realidade desagradável [...] e, através das fantasias que a criança constrói, ela se torna insensível à realidade em questão, o ego será poupado à ansiedade e não precisará recorrer a medidas defensivas contra os seus impulsos instintivos.

Com tudo isso, torna-se claro que, para ajudar Vítor, seria necessário um trabalho bastante consistente envolvendo professora, escola, pais, trabalho especializado (no qual me incluo), trabalho de conscientização dos colegas e de suas famílias, sem descartarmos a importância de um acompanhamento emocional para o menino. 
Acredito que, mesmo que ainda houvesse bastante a ser trabalhado não apenas com o Vítor, mas com seus colegas também, os meus objetivos foram alcançados, já que, além de um progresso na aprendizagem, a sua relação com a turma também apresentou melhoras. Essas evoluções me deixaram muito satisfeita, visto que talvez o fato de o Vítor estar recebendo esta atenção direcionada tenha permitido, além de melhoras pontuais nas suas dificuldades de aprendizagem, que ele se sentisse acolhido, respeitado e valorizado, o que resultou em uma melhora em sua autoestima e, consequentemente, nas suas dificuldades de aprendizagem e de relacionamento com os colegas.

\section{REFERÊNCIAS}

BRASIL. Secretaria de Educação Fundamental. Parâmetros curriculares nacionais: adaptações curriculares / Secretaria de Educação Fundamental. Secretaria de Educação Especial. Brasília: MEC/SEF/SEESP, 1998. Disponível em: <http://200.156.28.7/Nucleus/media/common/Downloads_PCN.PDF>. Acesso em: 04 de jun. 2013.

CORSO, L. Dificuldades de aprendizagem na educação infantil. Pátio Educação Infantil, ano VI, mar./jun. 2008.

FREUD, A. O ego e os mecanismos de defesa. Rio de Janeiro: Bup, 1968.

GOLA, M. de F. M. Instrumentos psicopedagógicos para conhecimento do sujeito que não aprende. Revista Psicopedagogia, São Paulo, v. 18, n. 49, p. 55-56, 1999.

GOLBERT, C.; MOOJEN, S. Dificuldades na aprendizagem escolar. In: SUKIENNIK, P. (Org). O aluno problema: transtornos emocionais de crianças e adolescentes. Porto Alegre: Mercado Aberto, 1996. p. 79-109.

LEMOS, A. C. M. Uma visão psicopedagógica do bullying escolar. Revista Psicopedagogia, São Paulo, v. 24, n. 73, p. 68-75, 2007. 
MOOJEN, S. Dificuldades ou transtornos de aprendizagem? In: RUBINSTEIN, E. (Org.) Psicopedagogia: uma prática, diferentes estilos. São Paulo: Casa do Psicólogo, 1999. p. 243-284.

. A escrita ortográfica na escola e na clínica: teoria, avaliação e tratamento. São Paulo: Casa do Psicólogo, 2009.

MOOJEN, S.; DORNELES, B.; COSTA, A. Avaliação psicopedagógica no TDAH. In: ROHDE, L.A.; MATTOS, P. (Org.). Princípios e práticas em TDAH: tratamento de déficit de atenção/hiperatividade. Porto Alegre: Artmed, 2003. p. 107-116.

ORGANIZAÇÃO MUNDIAL DA SAÚDE. Classificação de transtornos mentais e de comportamento da CID-10: descrições clínicas e diretrizes diagnósticas. Porto Alegre: Artes Médicas, 1993.

PAIN, S. Diagnóstico e tratamento dos problemas de aprendizagem. Porto Alegre: Artes Médicas, 1985.

ROTH, O. Duas dúzias de coisinhas à-toa que deixam a gente feliz. São Paulo: Ática, 2000.

WEISS, M. L. M. Psicopedagogia clínica: uma visão diagnóstica dos problemas de aprendizagem escolar. 4 ed. Rio de Janeiro: DP\&A, 1997. 


\section{Planeta Rooda 2.0: elaboração de projetos direcionados a alunos com dificuldades de aprendizagem}

Tássia Priscila Fagundes Grande

Patricia Alejandra Behar

A presente pesquisa busca analisar e discutir possibilidades de elaboração de projetos em ambientes virtuais de aprendizagem voltados a alunos que apresentam dificuldades de aprendizagem. O objetivo principal da pesquisa é responder a seguinte questão: "Como elaborar estratégias pedagógicas voltadas a alunos que apresentam dificuldades de aprendizagem através do ambiente virtual de aprendizagem Planeta Rooda 2.0?" Neste contexto, pretende analisar possibilidades de uso do Ambiente Virtual de Aprendizagem (doravante referido como AVA) Planeta Rooda 2.0 por professores do ensino fundamental, tendo por base o projeto de trabalho com foco em seus alunos.

Para isso, foi realizado um curso de extensão, ${ }^{1}$ a fim de instrumentalizar os docentes para a utilização do AVA, discutir propostas

${ }^{1} \mathrm{O}$ curso de extensão "Planeta Rooda 2.0: possibilidades didático-pedagógicas através de uma ferramenta tecnológica" ocorreu no período de 25/04/2013 a 23/05/2013 com aulas semanais e teve 8 participantes. 
de planejamento pedagógico que contextualizassem o uso do computador na escola e identificar suas concepções de dificuldade de aprendizagem. Com esses subsídios, os professores receberam uma proposta de elaboração de projetos individuais, tendo o Planeta Rooda 2.0 como ferramenta, voltado para alunos com dificuldades de aprendizagem. Um trabalho de abordagem qualitativa do tipo estudo de caso foi realizado a partir de um grupo focal de participantes, com tema preestabelecido e tomando como base um recorte desse curso de extensão.

Muitos docentes buscam aperfeiçoamento na área das tecnologias, principalmente para utilizarem o computador de forma interessante e atrativa nas aulas. Demonstram interesse em usar ferramentas educacionais, Ambientes Virtuais de Aprendizagem ${ }^{2}$ (AVA) e jogos educacionais, a fim de encontrar formas que atendam a maneira como os alunos atuais aprendem, buscando também auxiliar nas dificuldades que os mesmos possam apresentar. Nesse sentido, o investimento em recursos tecnológicos e a capacitação de profissionais do ensino possibilitaram progressos nas estratégias dos professores que tinham como intuito auxiliar na aprendizagem tanto dos alunos em geral como daqueles que apresentam dificuldades de aprendizagem.

Tais dificuldades são cada vez mais destacadas no meio escolar. Os discentes que, porventura, se sobressaem negativamente apresentando notas baixas, falta de atenção, agitamento e atrasos em relação ao restante da turma são encaixados no grupo de alunos que apresentam dificuldades de aprendizagem. Sendo assim, esses alunos necessitam de uma atenção diferenciada dos docentes, para que consigam acompanhar o desenvolvimento da turma. Portanto, os professores precisam estar preparados para trabalhar com diferentes níveis de conhecimento e formas

\footnotetext{
${ }^{2}$ Espaço na internet onde ocorrem interações entre sujeitos, normalmente por meio de uma plataforma, na qual as interações dos envolvidos têm como foco principal a aprendizagem.
} 
de aprendizagens dos alunos, buscando estratégias e ferramentas que sanem as necessidades de todos.

O AVA Planeta Rooda 2.0 constitui-se em um ambiente para educação infantil e ensino fundamental o qual os professores podem utilizar para trabalhos e interação com seus alunos. Neste ambiente, há espaços para escrita, desenho, compartilhamento de materiais, como documentos escritos e vídeos, interação dos alunos com os colegas e professores, avaliação, debates, entre outras atividades.

A seguir são delineados os principais pontos abordados neste artigo. Primeiramente, são elencados os termos "ciberinfância" e "nativos digitais", bem como é abordada sua diferenciação em relação aos "imigrantes digitais". Em seguida, são referenciadas algumas ferramentas educacionais e ambientes virtuais de aprendizagem com vista a contextualizar a informática na sala de aula. Logo depois, a importância de se trabalhar Tecnologias de Informação e Comunicação (TIC) nas turmas de alunos com e sem dificuldades de aprendizagem é destacada. Finalmente, enfoca-se o AVA Planeta Rooda 2.0 e como este pode apoiar as práticas pedagógicas.

\section{A CIBERINFÂNCIA}

Esse termo refere-se às crianças que nasceram já em contato com as tecnologias e as têm inseridas de forma naturalizada em suas atividades cotidianas. Por exemplo, interagem com celulares, notebooks, tablets, entre outros, com tamanha habilidade que um adulto não consegue acompanhá-las no sentido de interação intuitiva. Os celulares são um bom exemplo: as crianças já utilizam os mais modernos que funcionam a partir do toque na tela, jogam, usam aplicativos e acessam redes sociais. Basta alguns minutos para compreenderem a lógica da tecnologia e a usarem com destreza. Por outro lado, os adultos demoram em se adaptar à forma de interação com o aparelho, por estarem acostumados com as teclas convencionais. 
De acordo com Dornelles (2005), assim como as demais crises mundiais, está-se vivendo uma crise da infância que se evidencia na busca por novos modos de se ver e tratar as práticas com as crianças. Os espaços que as crianças ocupam, dentro da nova cultura na qual estão inseridas, produzem infâncias globalizadas que têm contato diretamente com o mundo. Nesse novo universo digital, as crianças estão interagindo, brincando, criando de forma diferente, e a ludicidade das brincadeiras também sofreu alterações. Segundo Dornelles (2005, p. 80), atualmente são

[...] em lan-houses informatizados que se produzem as infâncias globalizadas e este é o espaço da ciberinfância, ou seja, da infância on-line, da infância daqueles que estão conectados à esfera digital dos computadores, da internet, dos games, do mouse, do self-service, do controle-remoto [...]. Esta é a infância multimídia e das novas tecnologias.

Segundo Levin (2007), devido às diferentes expressões dos meios de comunicação, as experiências e vivências das crianças dos tempos atuais se estruturam e se desenvolvem de maneira distinta das de qualquer outra época. Com o surgimento da internet, a comunicação e a interação através do meio virtual têm se tornado mais presentes na vida das crianças, em todos os aspectos, redimensionando, assim, a função do seu universo imaginário.

Ao irem para a escola, os ciberinfantes encontram uma realidade com a qual não estão acostumados em casa: eles devem se concentrar em um só assunto, muitas vezes não podem interagir com os colegas, e o tempo é completamente diferente. Nesta perspectiva, os professores vêm buscando possibilidades de mudanças na sala de aula para TIC atingir o interesse dessa nova geração de alunos. Com isso, os professores precisam confrontar suas práticas pedagógicas com a nova demanda de necessidades dos alunos a fim de valorizar a apresentação dos conteúdos pela perspectiva da turma. 
Vinculada a tais noções, é de significante auxílio uma formação para o docente que o contemple de forma a responder as especificidades e a necessidade de seus alunos e da sociedade que está imersa nas tecnologias de informação e comunicação. Nesse contexto, as TIC passam a ser uma ferramenta que aproxima o professor dos seus alunos e ambos da atual sociedade mundial.

\section{OS NATIVOS $\varepsilon$ IMIGRANTES DIGITAIS}

O termo "nativos digitais" é usado para referir-se às crianças que já nascem em contato com as tecnologias, com a sociedade em rede e não conseguem imaginar o mundo sem essa interação tecnológica por meio da web. Prensky (2001) caracteriza a atual geração de nativos digitais: a criança é um agente social "lendo" o ambiente à sua volta, a sua vida, de forma única e particular, por meio de diversas interpretações simbólicas determinadas pelas crianças entre si e com os adultos. A rapidez de informações se sobressai na interação dos nativos digitais com as tecnologias. De acordo com Palfrey e Gasser (2011, p. 12), "Os principais aspectos de suas vidas interações sociais, amizades, atividades cívicas - são mediados pelas tecnologias. E não conheceram nenhum modo de vida diferente”.

Os "imigrantes digitais", segundo Prensky (2001, p. 2), ${ }^{3}$ são "Aqueles que não nasceram no mundo digital, mas em alguma época de suas vidas, ficaram fascinados e adotaram muitos ou a maioria dos aspectos da nova tecnologia [...]". Portanto, trata-se de indivíduos que utilizam as tecnologias e ainda as veem como novidade. Precisam de materiais impressos e interagem na rede, na maioria das vezes, apenas com conhecidos. Nesse contexto, os professores são identificados como imigrantes digitais, já que, ao lidar com o computador, apresentam receio de manipulação das ferramentas e insegurança em relação ao funcionamento correto do equipamento. Também possuem dificuldades e receio em resolver os problemas que surgem eventualmente, fato que os leva a pedir ajuda ou,

\footnotetext{
3 Tradução nossa.
} 
na pior das hipóteses, a evitar a interação com a tecnologia. O computador é usualmente utilizado para pesquisa, escrita de texto e criação de desenho. As tecnologias de informação e comunicação, para estes professores, não são ferramentas com as quais estejam habituados, visto que a velocidade com que as informações circulam supera a velocidade com que eles se adaptam às novas tecnologias. As relações e ligações entre assuntos, as interações entre pessoas, conhecidas ou não, são realidades presentes no mundo virtual, que lentamente passam a ser assimiladas e aceitas pelos adultos. Segundo Lévy (2000, p. 27):

[...] Estamos em vias de penetrar em uma espécie de além da cultura, cujo sistema simbólico poderia ser formulado assim: virtualmente, tudo pode entrar em relação com tudo. Este sistema de correspondência está intimamente ligado a uma descoberta prática que marca uma nova etapa do desenvolvimento humano [...].

Portanto, para a inserção da tecnologia na prática educacional, principalmente ao professor caberá desenvolver um novo olhar voltado para as novas gerações e para a forma como irá interagir com elas, pois, como diz Silva (2013, p. 143),

\footnotetext{
[...] Usar a tecnologia não é apenas trocar um material, como caderno e caneta, por um computador. A mudança é muito mais profunda e extrema. O mundo futuro vai exigir habilidades além das capacidades básicas de memória, atenção e concentração, que foram suficientes para escola do século XIX.
}

Com isso, é ressaltada a importância dos estudos sobre tecnologias relacionadas à educação na formação de professores, pois esse conhecimento pode ajudá-los a elaborar novas estratégias pedagógicas, envolvendo essa temática e refletindo sobre o seu papel na aprendizagem dos alunos. 


\section{AVA $\varepsilon$ FERRAMENTAS EDUCACIONAIS NA SALA DE AULA}

As Tecnologias de Informação e Comunicação (TIC) propiciam a interação tanto com colegas, como com pessoas de todo o mundo, que nem precisam ser alfabetizadas para isso, pois diversas ferramentas apresentam interação por voz ou por imagem através de webcams. As redes sociais, que são os meios mais populares para esse tipo de comunicação, já se aperfeiçoaram nesse sentido, implementando a conversa por voz e vídeo em seu bate-papo, como o Facebook.

Além de interagir e se comunicar, as crianças navegam por outras ferramentas relacionadas à criação de sites e blogs, editores de imagens, som e vídeos. Por sua vez, com a inserção da informática na sala de aula, muitos professores vêm buscando alternativas para desenvolver estratégias que contenham recursos tecnológicos em seu contexto, a fim de tornar as aulas mais atrativas e próximas da realidade dos alunos.

Ambientes Virtuais de Aprendizagem (AVA) são, de acordo com Behar (2009, p. 29), “[...] espaços na internet formados pelos sujeitos e suas interações e formas de comunicação e interação que se estabelecem por meio de uma plataforma, tendo como foco principal a aprendizagem". Esse recurso é de grande utilização para os professores na Educação a Distância (EAD), podendo servir de suporte para aulas presencias e semipresenciais, criando ambientes que vão além da escola. Os professores podem utilizar com seus alunos as ferramentas que, normalmente, os AVA apresentam - repositório de arquivos, fóruns, bate-papo, espaços para exercícios diversos, entre outros. Nos AVA as trocas através da interação são constantes, o que torna esse ambiente rico para qualquer indivíduo, porque, independentemente de ser aluno, tutor ou professor, todos são aprendizes.

A seguir são elencadas algumas possibilidades de AVA e ferramentas educacionais gratuitas, de fácil acesso, tanto para docentes como para discentes. Elas reforçam e exemplificam novas ideias que vêm 
sendo implementadas pelos professores e recebidas e utilizadas pelos alunos de forma satisfatória.

\section{Planeta Rooda}

O Planeta Rooda $2.0^{4}$ (http://www.nuted.ufrgs.br/planeta2/) é um exemplo de Ambiente Virtual de Aprendizagem, livre, ${ }^{5}$ voltado para as crianças, que tem como ferramentas blog, fórum, biblioteca, editor de desenhos, player, entre outros que serão apresentados neste artigo.

\section{Weebly}

Trata-se de uma ferramenta para criação de páginas pessoais na internet. O Weebly (http://www.weebly.com/index.php?lang=pt) é de fácil utilização por ser intuitivo, já que a inserção de grande parte das possibilidades de itens na página é feita por meio da ação de arrastar e colar. A página criada pode ter vídeo, imagens, sons, links, arquivos etc., e é em português, o que agrada a maioria dos usuários pouco familiarizados com a tecnologia. Apresenta algumas funcionalidades pagas, mas pode-se usar apenas a parte livre.

\section{Pixton}

É uma ferramenta para criação de Histórias em Quadrinhos (HQ), de simples utilização, já que é totalmente editável quando salvo dentro da própria ferramenta. Possui uma grande variedade de elementos para compor as $\mathrm{HQ}$, e o usuário pode escolher item por item, assim como cenários e personagens predefinidos. Conta com o recurso de impressão do material, dando a possibilidade de criação de HQ para distribuições ou registro na escola.

\footnotetext{
${ }^{4}$ Planeta Rooda 2.0 possui esse “ 2.0 ” em sua nomenclatura por se tratar da segunda versão criada.

${ }^{5}$ Livre: o programa pode ser copiado, executado e até modificado pelo usuário gratuitamente.
} 
O Pixton (http://www.pixton.com/br/) possui a versão livre, porém nem todas suas funcionalidades são liberadas. Também possui versão paga, voltada para escolas e empresas.

\section{O USO DAS TIC POR ALUNOS QUE APRESENTAM, OU NÃO, DIFICULDADES DE APRENDIZAGEM}

As Tecnologias de Informação e Comunicação (TIC), presentes cada vez mais na sociedade e em evolução constante, também estão sendo inseridas no ambiente escolar, de forma lenta e gradual, por parte dos professores. É necessário, neste contexto, enfatizar a importância do uso das tecnologias com alunos com e sem dificuldades de aprendizagem.

Segundo Marchesi (2006), são considerados alunos com dificuldades de aprendizagem: os alunos com atraso significativos nas aprendizagens escolares, com problemas emocionais ou de comportamento e desmotivados. Existem três possíveis variáveis que influenciam no surgimento dessas dificuldades: psicológicas (relacionadas a fatores cognitivos e psicoemocionais dos alunos); socioculturais (vinculadas ao contexto social do aluno e às características familiares); e institucionais (associadas à escola, aos métodos de ensino, a currículos mal desenvolvidos, a poucos recursos).

As TIC na educação, em diferentes pontos, podem auxiliar na aprendizagem, apresentando diversas possibilidades de interação entre os alunos. Neste sentido, as propostas de trabalhos cooperativos entre grupo, utilizando ferramentas educacionais, auxiliariam os alunos, principalmente aqueles com dificuldades, como escreve Marchesi (2006, p. 36): "Não há dúvida de que o trabalho cooperativo dos alunos é uma estratégia positiva para aprender, pois ajuda a elaborar a informação, a conversar sobre ela e a buscar soluções negociadas com os colegas”. 
Os docentes, como imigrantes digitais na maioria dos casos, têm a oportunidade de aprender com os alunos, buscar conhecer as tecnologias, softwares, ferramentas educacionais da web que estes conhecem, gostam e utilizam. Então, professores mais seguros poderão selecionar os recursos tecnológicos mais viáveis e montar a aula a partir das sugestões dos alunos. Esse processo de interação entre professor e alunos, no qual o docente oportuniza à sua turma participar das decisões sobre a construção da aula, também, segundo Marchesi (2006, p. 39), é importante para os alunos desmotivados: "A percepção do aluno de que se conta com ele e de que pode participar de alguma maneira das decisões que o afetam contribui para motivá-lo e para evitar que abandone as atividades escolares".

Para alguns discentes que apresentam dificuldade de atenção, as atividades que envolvem repetição também são importantes para suas aprendizagens. A utilização de memorização repetitiva para automatizar as relações cerebrais que o aluno virá a estabelecer é uma alternativa. Alguns softwares e jogos educacionais desempenham bem esse papel, pois trabalham com o ato de repetir para atingir metas, além de inserirem histórias e personagens para melhor contextualização da atividade. Assim, o processo de automatismo é importante para o aluno realizar as atividades com mais segurança.

O computador oferece diferentes formas de leitura, portanto o aluno tem acesso a, além dos livros, outros tipos textuais, como as histórias em quadrinhos, cartazes, vídeos, o que torna a leitura mais atrativa e centra a atenção dos discentes. Marchesi (2006, p. 48) afirma que “[...] a utilização de formatos audiovisuais e auditivos, próprios do sistema de multimídias, ajuda a processar a informação com maior eficácia, o que é especialmente positivo para aqueles alunos com dificuldades de centrar sua atenção".

Dessa forma, as tecnologias da informação e comunicação auxiliam no aprendizado dos alunos com e sem dificuldades de aprendizagem, 
intervindo em diferentes pontos de percepção dos discentes. Desde a forma como ocorre a interação até a frequência de uso influenciam no modo como estes alunos irão perceber os conteúdos trabalhados e fazer suas apropriações. Estes são alguns pontos a serem destacados na utilização das TIC na sala de aula, outros serão referidos junto às análises por estarem relacionados às dificuldades no aprendizado específicas que surgiram durante a pesquisa.

É muito importante o papel do professor nesse processo, pois ele será o agente que fará a inserção das TIC na sala de aula, que as apresentará para a turma, que irá planejar e propor as atividades. Cabe-lhe buscar ferramentas sobre as quais tenha conhecimento, sentindo-se seguro no trabalho com os alunos, dando retorno para suas atividades e incentivando a participação de todos presencial ou virtualmente.

\section{Apresentando o Planeta ROODA 2.0}

O Planeta Rooda $2.0^{6}$ é um AVA voltado para a Educação Infantil e o Ensino Fundamental. É caracterizado por ser ambientado no espaço sideral. Tem, como opções de inserção nos ambientes dentro das turmas, elementos decorativos (árvores, pedras e plantas) e funcionalidades que são representadas por "iglus". Por exemplo, cada professor pode:

- escolher, através do gerenciamento de turma, as ferramentas que o auxiliarão a desenvolver suas práticas pedagógicas;

- utilizar diferentes possibilidades de interação/comunicação nele existente para propor a utilização das mesmas de forma síncrona e assíncrona entre os usuários;

- fazer o compartilhamento de links, imagens, textos, vídeos;

- realizar atividades individuais e em grupo;

\footnotetext{
${ }^{6}$ Disponível em: <http://www.nuted.ufrgs.br/planeta2/>. Acesso em: 25 jun. 2013.
} 
- registrar informações pessoais;

- gerenciar turmas/grupos.

Constitui-se em um ambiente centrado no usuário, ou seja, quando habilitado pelo professor, o mesmo pode ter acesso a mais de uma turma/grupo com o mesmo login, assim como o aluno. $\mathrm{O}$ vínculo com essas turmas/grupos pode variar entre professor, monitor e aluno, dependendo da escolha dos recursos disponíveis.

Na Figura 1 é mostrada a tela de login do Planeta Rooda 2.0, que também dá acesso à tela de cadastro.

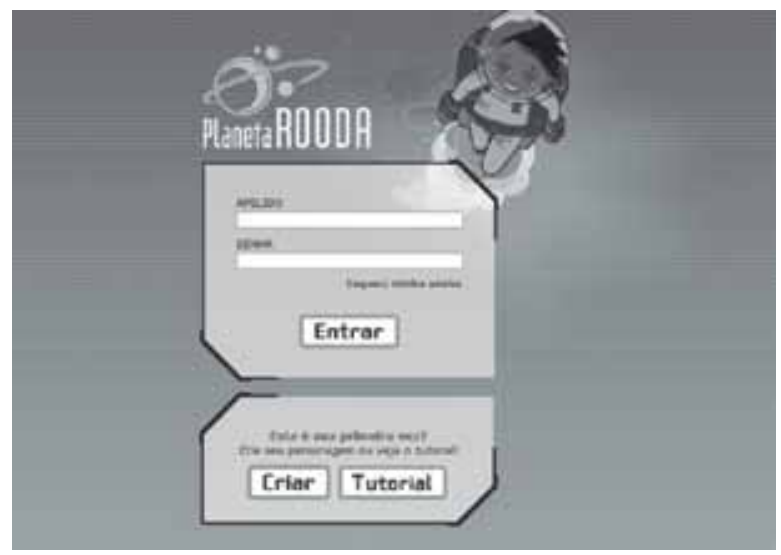

Figura 1 - Planeta Rooda 2.0

Na gerência do Planeta Rooda, o professor possui a liberdade de escolher como serão as interações no ambiente, por exemplo, se no fórum, os alunos poderão somente responder ou também terão a possibilidade de criar tópicos e ainda se poderão excluir postagens ou se isso caberá apenas ao professor.

Todas as funcionalidades dependem da escolha do docente, ou seja, se a turma poderá utilizar apenas a biblioteca e o player numa aula, se na próxima também publicarão no fórum. Também possui o sistema 
de aprovações de postagens e inserção de materiais no AVA, que só aparecerão para todos quando o professor aprovar. $\mathrm{O}$ gerenciamento $\mathrm{da}(\mathrm{s})$ turma(s) é feito pelo respectivo professor responsável por ela(s) (inicialmente) e por quem mais ele escolher posteriormente, como mais professores, monitores e até mesmo alunos.

Atualmente as funcionalidades são:

- Biblioteca ${ }^{7}$ (Figura 2): armazenamento de documentos, arquivos e imagens:

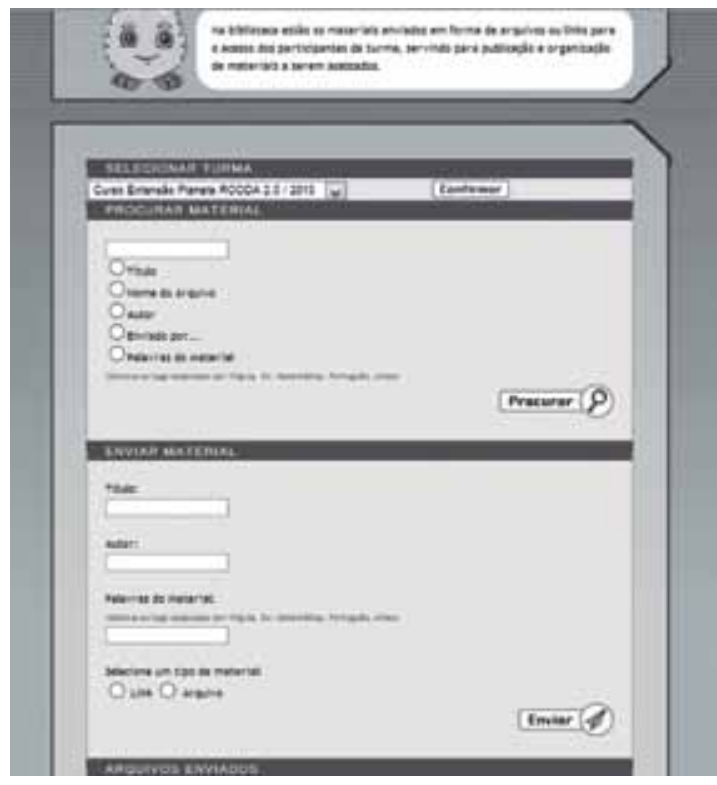

Figura 2 - Biblioteca

- Blog: pode ser $b l o g$ pessoal do aluno, para registros pessoais, $b l o g$ da turma, ou até mesmo blog coletivo, com membros integrantes da turma.

- Planeta Arte: criação de desenhos.

${ }^{7}$ Disponível em: <http://www.nuted.ufrgs.br/planeta2/funcionalidades/biblioteca/ biblioteca.php?turma=205>. Acesso em: 25 jun. 2013. 
- Portfólio: desenvolvimento e armazenamento de projetos do professor, ou da turma.

- Aulas: organização das aulas, para auxílio e consulta do professor e dos alunos.

- Player $^{8}$ (Figura 3): armazenamento de vídeos.

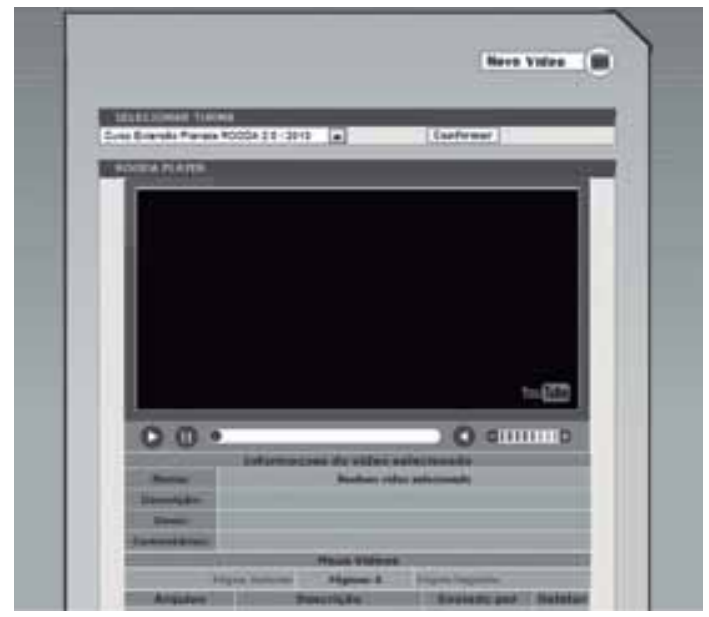

Figura 3 - Player

- Fórum: espaço para debates.

- Avatar9 (Figura 4): o usuário escolhe a caracterização do seu avatar, dentro das possibilidades disponibilizadas no sistema:

${ }^{8}$ Disponível em: <http://www.nuted.ufrgs.br/planeta2/funcionalidades/roodaplayer/index.php?turma=205>. Acesso em: 25 jun. 2013.

${ }_{9}^{9}$ Disponível em: <http://www.nuted.ufrgs.br/planeta2/funcionalidades/criar_personagem/criar_personagem.php?id_char_as=416>. Acesso em: 25 jun. 2013. 


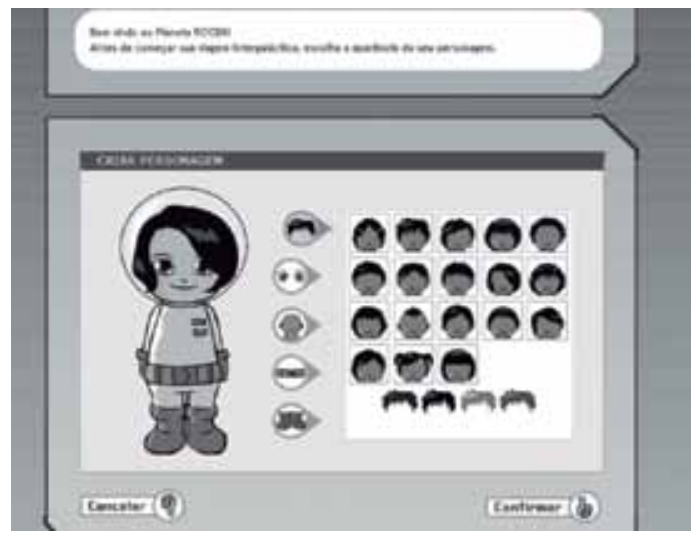

Figura 4 - Avatar

Portanto, este AVA, desenvolvido na Faculdade de Educação por educadores, designers e programadores, possui diversas possibilidades de utilização na sala de aula por meio de suas ferramentas, dependendo apenas da criatividade e das estratégias pedagógicas dos professores que irão usá-lo. Por ser de fácil navegação e apresentar imagens nos botões de acesso, pode seu usado por alunos não alfabetizados, pelo fato de ser intuitivo.

Na próxima subseção é apresentada a metodologia de pesquisa adotada para o desenvolvimento do estudo relatado neste artigo, mostrando como os dados foram coletados, separados, categorizados e analisados.

\section{METODOLOGIA DE PESQUISA}

A presente pesquisa caracteriza-se como estudo de abordagem qualitativa do tipo estudo de caso. Por estudo de caso, entende-se uma investigação que, segundo Yin (2005, p. 33), "compreende um método que abrange tudo - tratando da lógica de planejamento, das técnicas de coletas de dados e das abordagens específicas à análise dos mesmos". Creswell (2007) caracteriza a pesquisa como de abordagem qualitativa por ser uma coleta de dados emergentes realizada pelo pesquisador, tendo o desenvolvimento de temas a partir desses dados. 
Como se disse antes, para obtenção dos dados, realizou-se um curso de extensão ${ }^{10}$ no Laboratório de Informática do Ensino Superior (LIES). Fizeram parte da pesquisa oito professores do Ensino Fundamental da rede pública e privada e alunos da licenciatura.

Os dados foram levantados a partir dos registros das observações e das contribuições/registros dos alunos no AVA Planeta Rooda 2.0 e, também, via e-mail. Portanto, os dados foram coletados a partir dos registros no AVA, por meio de fórum, blog, aula, portfólio, biblioteca, projetos elaborados, interações feitas por e-mail e observações da pesquisadora. A atividade principal do curso foi a elaboração de um projeto voltado para alunos com dificuldade de aprendizagem. Dessa forma, buscou-se perceber como seriam elaboradas estratégias de trabalho com o Planeta Rooda 2.0.

\section{0 curso de Extensão}

Foram abordados os seguintes temas: (1) Ambientes Virtuais de Aprendizagem (AVA) e os espaços digitais; (2) ciberinfância - a geração dos nativos e imigrantes digitais; (3) ferramentas educacionais de aprendizagem; (4) letramento digital; e (5) concepções de dificuldades de aprendizagem. No curso houve também a montagem de conteúdo e páginas HTML.

As aulas foram ministradas com o suporte de e-mail, do Objeto de Aprendizagem (OA) Letramento Digital ${ }^{11}$ e do AVA Planeta Rooda 2.0, especificamente as funcionalidades: fórum (ambos para interação do grupo), portfólio (projetos e publicação de arquivos), biblioteca (publicação de atividades e de materiais sugeridos pelos alunos), blog (publicação de atividades, de materiais sugeridos pelos alunos e interação entre o grupo), player (compartilhamento de vídeos e realização de atividades), Planeta

${ }^{10}$ Disponível em: <http://planetarooda20.weebly.com/index.html>.

${ }^{11}$ Disponível em:<http://www.nuted.ufrgs.br/objetos_de_aprendizagem/2012/Letramento\%20Digital/>. 
Arte (criação de desenhos), Planeta Pergunta (para criação de questionários e atividades de perguntas e respostas), aulas (para organização de aulas criadas pelos participantes).

O espaço possibilitou a familiarização dos participantes com este ambiente digital e o registro das discussões dos temas propostos. A escolha do AVA Planeta Rooda 2.0 foi feita, justamente, com este intuito: os participantes conhecerem o AVA e poderem utilizar os materiais elaborados durante o curso com suas turmas.

O curso foi organizado em cinco encontros presenciais, uma vez por semana, no Laboratório de Informática do Ensino Superior. Além disso, os participantes também realizaram atividades e leituras a distância, totalizando uma carga horária de 30 horas-aula. Os envolvidos na pesquisa tinham as seguintes características:

- 3 professoras do ensino fundamental da rede pública estadual;

- 1 professora de Sociologia e estudante de Ciências Sociais;

- 2 estudantes das licenciaturas, nas áreas de Matemática e Ciências Sociais;

- 1 pedagoga;

- 1 nutricionista engajada em curso de educação alimentar nas escolas.

As aulas do curso foram disponibilizadas em página na web criada na ferramenta Weebly; nela foram socializados e-mails para contato com as professoras e links para o Objeto de Aprendizagem "LetEdu - Letramento Digital”, e o AVA Planeta Rooda 2.0. Neste foram armazenados os materiais produzidos pelos alunos, além de ter funcionado como ambiente para discussões, resoluções de dúvidas e interações dos alunos da turma entre si e com as docentes.

O Objeto de Aprendizagem LetEdu - Letramento Digital tem como objetivo principal auxiliar professores da educação infantil e do ensino 
fundamental no planejamento, no desenvolvimento e no uso das tecnologias de informação e comunicação em sala de aula.

O curso foi organizado de forma que cada temática fosse trabalhada em um dia de aula, com atividades a distância no decorrer da semana. Cada aula possuía um texto, desafios, sendo que duas aulas envolveram apresentação de ferramentas educacionais, além de interações virtuais/presenciais e leituras.

A seguir, apresenta-se uma tabela com as atividades propostas no curso e seus enunciados:

Tabela 1 - Atividades do curso

\begin{tabular}{|c|c|c|}
\hline Assuntos & Atividade & Enunciado \\
\hline $\begin{array}{l}\text { Apresentação } \\
\text { sobre } \\
\text { ciberinfância, } \\
\text { imigrantes e } \\
\text { nativos digitais }\end{array}$ & $\begin{array}{l}\text { Resenha referente } \\
\text { ao texto do Módulo } \\
1 \text { disponível no AO } \\
\text { Letramento digital }\end{array}$ & $\begin{array}{l}\text { Escreva uma pequena resenha } \\
\text { salientando possíveis modificações } \\
\text { que você acredita terem ocorrido } \\
\text { na infância nos últimos anos. }\end{array}$ \\
\hline \multirow[t]{2}{*}{$\begin{array}{l}\text { Discussão sobre } \\
\text { Informática na } \\
\text { Educação e AVA }\end{array}$} & $\begin{array}{l}\text { Fórum abordando os } \\
\text { temas "Informática na } \\
\text { Educação" e "o uso de } \\
\text { Ambientes Virtuais } \\
\text { de Aprendizagem" }\end{array}$ & $\begin{array}{l}\text { Relate experiências que tiveram com } \\
\text { os temas "Informática na Educação" } \\
\text { e "o uso de Ambientes Virtuais de } \\
\text { Aprendizagem" e seus interesses } \\
\text { em utilizar em sala de aula. }\end{array}$ \\
\hline & História em Quadrinhos & $\begin{array}{l}\text { Crie uma história em quadrinhos que } \\
\text { ilustre a Informática na Educação. } \\
\text { Poste no seu blog. }\end{array}$ \\
\hline \multirow[t]{2}{*}{$\begin{array}{l}\text { Discussão sobre } \\
\text { Letramento } \\
\text { Digital }\end{array}$} & $\begin{array}{l}\text { Texto referente ao } \\
\text { texto do Módulo } 2 \\
\text { disponível no AO } \\
\text { Letramento Digital }\end{array}$ & $\begin{array}{l}\text { Escreva um pequeno texto apontando } \\
\text { o que você entende por letramento } \\
\text { digital, explicitando as diferenças } \\
\text { entre letramento e alfabetização. }\end{array}$ \\
\hline & $\begin{array}{l}\text { Comentário sobre vídeo } \\
\text { "Letramento Digital" }\end{array}$ & $\begin{array}{l}\text { Assistir ao vídeo "Letramento } \\
\text { Digital" e comentar no Player. }\end{array}$ \\
\hline
\end{tabular}

continua... 


\begin{tabular}{|c|c|c|}
\hline \multirow[t]{2}{*}{$\begin{array}{l}\text { Discussão sobre } \\
\text { dificuldade de } \\
\text { aprendizagem }\end{array}$} & $\begin{array}{l}\text { Publicação na página do } \\
\text { curso sobre a concepção } \\
\text { de dificuldade de } \\
\text { aprendizagem. }\end{array}$ & $\begin{array}{l}\text { Escrever sua concepção sobre "aluno } \\
\text { com dificuldade de aprendizagem". }\end{array}$ \\
\hline & $\begin{array}{l}\text { Projeto-postagem } \\
\text { na Biblioteca e } \\
\text { envio por } e \text {-mail. }\end{array}$ & $\begin{array}{l}\text { Monte um projeto ou planejamento } \\
\text { para alunos com dificuldades de } \\
\text { aprendizagem (já conhecida pelo } \\
\text { professor, pois deverá especificá-la } \\
\text { no projeto) sobre um tema livre de } \\
\text { interesse de suas turmas, utilizando } \\
\text { os recursos informáticos disponíveis } \\
\text { (incorporar o Planeta Rooda } 2.0 \\
\text { no planejamento e na aula). } \\
\text { Este projeto deverá ser destinado a } \\
\text { um público alvo (ensino fundamental: } \\
1^{\circ}, 2^{\circ}, 3^{\circ}, 4^{\circ} \text { ano) de sua escolha. } \\
\text { Deverá também ter objetivos, } \\
\text { justificativa, forma de avaliação } \\
\text { e materiais de apoio (textos, } \\
\text { vídeos, músicas, por exemplo). }\end{array}$ \\
\hline
\end{tabular}

O objetivo central desta etapa da pesquisa foi discutir e refletir sobre propostas de planejamento pedagógico que contextualizassem o uso do AVA Planeta Rooda 2.0 no ensino fundamental com alunos que apresentassem dificuldades de aprendizagem.

\section{Encaminhamento do estudo dos dados}

A metodologia de análise de conteúdo proposta por Moraes (1999) foi utilizada para esse estudo. Segundo o autor, trata-se de uma interpretação pessoal, por parte do pesquisador, relacionada à percepção que este tem dos dados. Sendo assim, o levantamento dos dados foi feito a partir das leituras, tanto dos registros no AVA e no e-mail, quanto dos registros e das observações da pesquisadora, buscando evidências que respondessem à questão da pesquisa. Tal processo possibilitou a produção de análises a partir do referencial teórico escolhido. Nessa perspectiva, o processo de análise foi construído em cinco etapas: 
- preparação das informações: momento em que os materiais foram lidos e trechos foram destacados a fim de auxiliar no desenvolvimento das próximas etapas;

- unitarização ou transformação do conteúdo em unidades: os materiais destacados foram relidos e separados de acordo com títulos que auxiliassem na solução da questão proposta pela pesquisa;

- classificação dos dados para análise: os dados foram divididos em seis tipos referentes às dificuldades de aprendizagem que surgiram a partir dos materiais analisados - dificuldades na utilização das tecnologias e dificuldade motora; dificuldade de expressão oral e escrita; dificuldade na compreensão/assimilação do conceito de número natural e na resolução de problemas com operação de divisão; aluno com hiperatividade; aluno com dislexia; aluno com retardo mental leve, traços de autismo e deficiência intelectual;

- descrição: houve a descrição das dificuldades e das estratégias elaboradas pelo professor;

- interpretação: por fim, nesta etapa, são produzidas a interpretação e a análise da pesquisadora a partir dos referenciais teóricos, com o intuito de responder à questão orientadora da pesquisa.

\section{ANÁLISE DOS DADOS}

A seguir é apresentada a análise dos dados, com base nos conceitos abordados e na fundamentação teórica. Ela decorre das interpretações da pesquisadora, apoiada em recortes selecionados dos projetos criados pelos professores e em participações dos mesmos no Ambiente Virtual de Aprendizagem. Os nomes não serão utilizados para preservar a identidade dos participantes, que foram denominados aleatoriamente por letras. De forma particular, cada sujeito buscou atender as dificuldades de seus alunos nos projetos 
elaborados, utilizando o Planeta Rooda 2.0 como ferramenta, o que é mostrado a seguir.

\section{Aluno com hiperatividade}

O participante E trouxe a hiperatividade em seu projeto e propõe o seguinte:

[...] elaboro atividades dinâmicas em que o aluno não tenha que ficar concentrado apenas em uma atividade, visto que o plano é voltado ao aluno com hiperatividade. Assim cada atividade tem um tempo curto, objetivando, desta forma, conseguir que o aluno faça a sua aprendizagem de maneira satisfatória.

Atividades curtas que envolvem leituras fáceis podem ser interessantes e eficazes para alunos que têm dificuldade em manter a atenção: "É preciso ajudar os alunos a terem consciência de que as tarefas podem ser feitas de forma mais fácil se dirigirem a atenção para aquilo que é importante e utilizarem as estratégias adequadas" (Marchesi, 2006, p. 47-48).

\section{Aluno com retardo mental leve, traços de autismo/deficiência intelectual}

Nesta categoria, os participantes H e G apresentam distintas propostas para trabalhar com seus alunos.

O participante $\mathrm{H}$ endereça as atividades a um aluno com "deficiência intelectual", um aluno mais velho, com idade igual ou superior a 20 anos. As atividades sugeridas envolveriam a temática da consciência ecológica e proporiam a utilização da estratégia de reconhecimento de imagens de, por exemplo, frutas, flores, árvores, entre outras, postadas no blog da turma pela professora. Os alunos deveriam realizar a escrita dos respectivos nomes. Os comentários com os nomes das 
imagens deveriam aparecer no campo de comentários do blog. Outras atividades envolveriam desenhos no Arte sobre qual fruta gostam mais e apresentação de vídeo no player sobre as estruturas das plantas. $\mathrm{H}$ sugeriu, também, a elaboração de cartazes em grupo e postagem no blog da foto dos trabalhos.

As atividades apresentadas pelo participante $H$ são simples porém envolvem interação e colaboração dos alunos - e pressupõem que o professor esteja envolvido nas propostas, fazendo intervenções importantes que facilitarão a aprendizagem da turma. O trabalho com pessoas com atrasos, devido a deficiência intelectual ou alguma outra, requer um cuidado especial por parte dos docentes, pois existe um envolvimento emocional que é de extrema importância nesse processo. Foi destacado isso no projeto do participante $\mathrm{H}$ e também no do participante $G$, que segue:

Foco: aluno com retardo mental leve e traços autistas.

Autismo é uma síndrome complexa reconhecida como uma desordem em espectro com vários graus de intensidade.

Pessoas com autismo têm "atraso ou funcionamento anormal” em algum grau nas três áreas seguintes:

- interação social;

- comunicação;

- padrões de comportamento que são manifestados através de interesses ou atividades estereotipadas, restritas e/ou repetitivas.

O participante $G$ destaca que seu aluno produz textos com coerência, mas tem dificuldade na motricidade fina. Sugere, então, a utilização do teclado no computador, pois ele auxilia o aluno na escrita rápida, livrando-o do obstáculo de atrasos na escrita por limitações motoras. Destaca, também, a troca de informações com os colegas nas 
ferramentas do Planeta Rooda 2.0, a fim de aumentar a socialização e diminuir possíveis quadros de bullying.

G utilizou o blog para a construção de uma linha de tempo da história de vida do aluno e o Portfólio para estabelecer relações entre fatos que tenham ocorrido em certas épocas de suas vidas e acontecimentos mundiais. Ademais, sugeriu uma escrita reflexiva sobre suas vidas, devendo o texto ser postado na Biblioteca para socialização com os colegas.

As estratégias elaboradas pelo participante $\mathrm{G}$ mostram que ele propõe atividades que englobam o contexto dos alunos, suas histórias, o que lhes dá mais elementos para reflexão na escrita que envolvam: (1) emoção; (2) diferentes atividades em variadas ferramentas do Planeta Rooda 2.0, destacando a interação com os colegas e a socialização dos materiais produzidos; (3) e o trabalho em si, que, por ser relacionado à memória e trazer eventos pessoais dos alunos, traduz-se como ação que estabelecerá laços entre os membros da turma e entre a turma e o professor. Nesse contexto, afirma Marchesi (2006, p. 38) que a “[...] corrente emocional que se cria entre cada aluno e cada professor é um fator importante para entender as relações mútuas e a atividade de aprendizagem".

\section{Dificuldade na compreensão/assimilação do conceito de número natural e na resolução de problemas com operação de divisão}

O participante D utilizou os recursos do Planeta Arte para atingir seu objetivo de auxiliar os alunos com dificuldades no processo de raciocínio lógico e na interpretação dos problemas envolvendo operações de divisão. Propôs que os alunos desenhassem objetos e os dividissem em grupos, seguindo os enunciados dos problemas. Isso foi proposto algumas vezes com diferentes objetos e quantidades, a 
fim de que os alunos repetissem a tarefa até que seu objetivo fosse compreendido pela turma.

Neste caso, o mecanismo de automatismo está sendo desenvolvido. Ele é muito importante para os alunos, pois trata-se do maior número de processos automáticos que o indivíduo realiza. Com ele o aluno realiza cálculos, por exemplo, de forma segura e não cansativa, tendo de resolver todas as partes do mesmo, pois já compreendeu o conceito e, também, o processo (Marchesi, 2006).

$\mathrm{G}$ também propôs atividades no blog e no fórum: a turma deveria conversar no ambiente virtual sobre soluções para os problemas, apresentando, assim, diferentes formas de interação entre os alunos.

\section{Dificuldades na utilização das}

tecnologias e dificuldade motora

$\mathrm{O}$ participante A justificou a escolha por essas dificuldades, afirmando o seguinte:

Não basta saber que “tem rede”, é necessário aprender a utilizar os aplicativos e programas com desenvoltura.

Devido às limitadas condições da escola em que trabalha, ele reitera que não é possível trabalhar com turmas inteiras na sala de computador, portanto, abordaria o tema com pequenos grupos. $\mathrm{O}$ foco seria desde o básico - como melhorar a coordenação motora - até desenvolver a leitura, a escrita e a atenção. Por meio de tais ponderações, percebe-se o cuidado do participante com o grau de conhecimento dos seus alunos sobre as tecnologias, já que se trata de uma comunidade de baixa renda que frequenta a escola.

Ele se utiliza da ferramenta Planeta Arte para desenvolver a coordenação motora através da criação de desenho livre, e do player a fim de 
trabalhar a atenção do aluno por meio de interpretação audiovisual. A leitura e a interpretação de texto serão trabalhadas com um material disponibilizado na Biblioteca. Também foram ofertados links com assuntos referentes ao texto postado pelos alunos no blog da turma para interação com os colegas. Nesse contexto, destaca-se a atividade utilizando o recurso audiovisual a fim de envolver a atenção do aluno e indo ao encontro do que Marchesi (2006) afirma sobre os diferentes recursos de leitura a serem usados de modo a tornar mais interessantes as aulas para aqueles alunos que têm dificuldade em manter a atenção. A abordagem da interação com os colegas através do blog, envolvendo a discussão sobre o texto, também é uma estratégia a se evidenciar, pois o aluno exercita a leitura, a escrita e o raciocínio por meio da conversa no $b \log$.

O participante $\mathrm{C}$ aborda as dificuldades motoras nas suas atividades da seguinte maneira:

Alguns alunos apresentarão problemas para usar as ferramentas, como mouse ou teclado, e o professor deverá auxiliar e tomar o cuidado de não deixar esses alunos se sentirem excluídos.

Este participante deixa claro, no seu projeto, a atenção que se deve dar ao aluno com dificuldade, o que remete a Marchesi (2006, p. 38) quando afirma que "As emoções do aluno condicionam sua atividade intelectual e sua motivação para aprender e, por sua vez, estão condicionadas pelas relações que o aluno experimenta com seus professores". Ou seja, o participante C preocupa-se com a evolução do seu aluno, sabendo que suas emoções de fracasso podem dificultar seu processo de aprendizagem. 


\section{Aluno com dislexia}

O participante $\mathrm{F}$ assim enuncia o conceito da dificuldade escolhida:

A dislexia é uma dificuldade que se manifesta justamente na leitura, impedindo o aluno de ser fluente, pois faz trocas ou omissões de letras, inverte sílabas, apresenta leitura lenta e ainda dá pulos de linhas ao ler um texto, dentre outras dificuldades.

Apresenta as seguintes estratégias para trabalhar com esse aluno:

- posicionar o aluno disléxico perto do professor, para receber ajuda facilmente;

- elogiar de forma verdadeira o que o aluno fizer ou disser bem, dando-lhe a oportunidade de "brilhar";

- criar e enfatizar rotina para ajudar o aluno a adquirir um sentido de organização;

- incentivar sua participação;

- incentivar o uso do corretor ortográfico de um processador de texto para auxiliar o aluno com dislexia.

Além dessas ações, as atividades envolvem participação do aluno em tarefas de escrita em grupo no blog e comentários sobre vídeo do player.

$\mathrm{O}$ participante $\mathrm{F}$ enfatizou o cuidado que o professor deve ter com o aluno, a atenção que lhe é necessária, o incentivo que se torna imprescindível para que suas dificuldades não se transformem em barreiras e o façam desanimar.

\section{Dificuldade de expressão oral e escrita}

Visando a melhorias da expressão oral e escrita dos seus alunos, o participante $B$ tem por objetivo o incentivo à leitura e à produção de gêneros textuais em suas diferentes formas de linguagens midiáticas. 
O professor dará atendimento individualizado aos alunos que apresentarem maiores graus de dificuldades. Serão estimulados a trabalharem colaborativamente, auxiliando-se mutuamente.

Nesse contexto, propôs duas atividades em grupo. A gravação de falas de personagens criados pelos integrantes do grupo com posterior postagem no player para comentários dos colegas. E uma pesquisa cujo roteiro deve ser elaborado pelos integrantes do grupo coletivamente e, ao final de sua realização, deve ser postada no blog do Planeta Rooda 2.0.

A interação com os colegas nas atividades auxiliará os alunos na comunicação, oralidade, desenvoltura, já que terão de decidir as vozes dos personagens e gravá-las, e posteriormente receber os comentários dos alunos sobre o feito. Segundo Marchesi (2006), é importante que os alunos com dificuldades interajam com os outros colegas que participam dos grupos como tutores, pois isso auxilia a centrar a atenção na atividade. Do mesmo modo, ocorrem as trocas de ideias entre os colegas com maior naturalidade, então o aluno pode se sentir mais à vontade ao tirar dúvidas com o colega tutor em vez de com o próprio professor.

\section{CONSIDERAÇÕES FINAIS}

Neste estudo, foi possível constatar que o Ambiente Virtual de Aprendizagem pode ser utilizado com alunos que apresentam dificuldades de aprendizagem e, ainda, que o professor e suas estratégias de ação são o que fazem a diferença nesse processo. Independente de qual seja a situação do aluno, o professor pode atendê-lo de forma satisfatória, oferecendo atenção e incentivo, respeitando seus limites e dando-lhe oportunidades de mostrar o que sabe, elevando sua autoestima.

O resultado deste estudo enfatiza a importância de os professores buscarem novos meios de proporcionar aprendizagem, sendo tecnológicos ou não, pois o que faz a diferença são as estratégias elaboradas 
pelos docentes. As tecnologias da informação e comunicação estão cada vez mais inseridas em todas as áreas da sociedade, e usá-las na educação, como mais uma forma de qualificá-la, é uma alternativa que mostra bons resultados, já comprovados.

Essas possibilidades não se esgotam por si, pois sabe-se que os alunos com dificuldades de aprendizagens necessitam de diferentes olhares e recursos para atender suas necessidades. Dentre estes, o Planeta Rooda 2.0 mostrou-se uma alternativa.

Cabe assinalar, por fim, que a pesquisa que foi objeto deste artigo diz respeito a um recorte do curso de extensão oferecido sobre o Planeta Rooda 2.0, tendo possibilitado o conhecimento das suas funcionalidades e a percepção de que elas se constituem em ricas possibilidades de trabalho com os alunos. Futuros estudos poderiam averiguar a prática destes projetos em sala de aula, evidenciando quais os resultados destas estratégias de ação no aprendizado dos alunos que apresentam as dificuldades destacadas neste texto.

\section{REFERÊNCIAS}

BEHAR, P. A. Modelos pedagógicos em educação a distância. Porto Alegre: Artmed, 2009.

CRESWELL, J. W. Projeto de pesquisa: método qualitativo, quantitativo e misto. Porto Alegre: Artmed, 2007.

CURSO Planeta Rooda 2.0: possibilidades didático-pedagógicas através de uma ferramenta tecnológica. Disponível em: $<$ http://planetarooda20.weebly. com/index.html>. Acesso em: 25 jun. 2013.

DORNELLES, L. V. Infâncias que nos escapam: da criança na rua à criança cyber. Petrópolis, RJ: Vozes, 2005.

LETEDU - Letramento Digital Objeto de Aprendizagem. Disponível em: $<$ http://www.nuted.ufrgs.br/objetos_de_aprendizagem/2012/Letramento\%20 Digital/modulo2.html >. Acesso em: 25 jun. 2013. 
LEVIN, E. Rumo a uma infância virtual? A imagem corporal sem corpo. Petrópolis, RJ: Vozes, 2007.

LÉVY, P. Cibercultura. São Paulo: Editora 34, 2000.

MARCHESI, A. O que será de nós, os maus alunos? Porto Alegre: Artmed, 2006. MORAES, R. Análise de conteúdo. Revista Educação, Porto Alegre, v. 22, n. 37, p. 7-32, mar. 1999.

NUTED - Núcleo de Tecnologia Digital Aplicada à Educação. Disponível em: <http://www.nuted.ufrgs.br/>. Acesso em: 25 de jun. 2013.

PALFREY, J.; GASSER, U. R. S. Nascidos na era digital: entendendo a primeira geração de nativos digitais. Porto Alegre: Artmed, 2011.

PLANETA Rooda 2.0. Disponível em: <http://www.nuted.ufrgs.br/planeta2/>. Acesso em: 25 jun. 2013.

PRENSKY, M. Digital natives, digital immigrants. On the Horizon, MCB University Press, v. 9, n. 5, Oct. 2001.

SILVA, P. K. L. A escola na era digital. In: ABREU, C. N.; EISENSTEIN, E.; ESTEFENON, S. G. B. (Org.). Vivendo esse mundo digital: impactos na saúde, na educação e nos comportamentos sociais. Porto Alegre: Artmed, 2013. p. 137-145. YIN, R. K. Estudo de caso: planejamento e métodos. Porto Alegre: Bookman, 2005. 


\section{Alfabetização e letramento: a produção de Histórias em Quadrinhos em ambiente informatizado}

Fabiana de Miranda Rocha

O presente capítulo pretende abordar questões acerca do processo de aprendizagem da leitura e da escrita apoiados pelo computador como recurso para tal aprendizagem, através do uso de um software educacional para edição de Histórias em Quadrinhos (HQ) com fins pedagógicos. $\mathrm{O}$ texto apresenta a análise de uma experiência envolvendo a área da linguagem com uma proposta de leitura e criação de HQ no ambiente informatizado de uma instituição de ensino pública.

A experiência analisada foi realizada em uma escola da rede pública estadual de ensino fundamental de Porto Alegre (Rio Grande do Sul). Tal experiência culminou na elaboração do presente texto e foi norteada pela seguinte problemática: Pode a prática pedagógica envolvendo o computador como recurso de aprendizagem contribuir para os processos de alfabetização e letramento dos alunos?

Em muitos espaços escolares, os ambientes informatizados ainda são vistos como mausoléus perto dos quais os professores têm certo receio de chegar e temem a proximidade dos seus alunos. Portanto, 
entendemos que seja importante pensar em possibilidades pedagógicas que aproximem professores e alunos dos laboratórios de informática, o que pode enriquecer o processo de construção dos mais diversos conhecimentos, inclusive da leitura e da escrita.

Dessa forma, o objetivo geral do capítulo é analisar a prática pedagógica envolvendo a leitura e a produção de histórias em quadrinhos, sendo a leitura realizada no suporte gibi e também no computador, e a construção das histórias, no software HagáQuê, ${ }^{1}$ em ambiente informatizado, a fim de refletir sobre a potencialidade do uso dos recursos de laboratórios de informática para qualificar e significar os processos de alfabetização e letramento.

Como principais referências que inspiram as reflexões feitas neste texto, valemo-nos da perspectiva sobre alfabetização e letramento de Magda Soares (2007), concepção também discutida por Piccoli e Camini (2012), da teoria da aprendizagem significativa de Ausubel (1982) e de estudos de Vygotsky (1998) sobre o desenvolvimento das crianças. Refletimos, também, acerca de questões referentes à relação entre tecnologia e educação à luz de concepções de Moran, Masseto e Behrens (2000).

A análise realizada permitiu refletir sobre alguns pontos específicos da experiência apresentada. Considerando os referenciais escolhidos, constatamos que a construção de histórias em quadrinhos em ambiente informatizado, mesmo estando os alunos em diferentes níveis de desenvolvimento, pode propiciar uma ocasião de expressão das ideias próprias de cada um, o que dá significado às produções e proporciona um sentimento de satisfação com o material de sua autoria, enriquecendo, assim, os processos de alfabetização e letramento.

\footnotetext{
${ }^{1}$ Software educacional para edição de histórias em quadrinhos com fins pedagógicos. Seu uso é gratuito e pode ser livremente utilizado como um recurso de aprendizagem.
} 


\section{OS PROCESSOS DE ALFABETIZAÇÃO \& LETRAMENTO AGREGADOS ÁS HISTÓRIAS EM QUADRINHOS}

Um dos grandes desafios da escola contemporânea é que todos aprendam a ler e a escrever, e mais: que aprendam a fazer uso adequado da leitura e da escrita em práticas sociais que envolvem essas atividades. $\mathrm{O}$ fato de uma pessoa ser alfabetizada não é socialmente suficiente, é preciso desenvolver habilidades e competências que vão além do conhecimento da mecânica da leitura e da escrita para a participação competente e efetiva nas mais diversas práticas sociais. O processo inicial da escolarização enfatiza muito a aquisição da leitura e da escrita, uma vez que as habilidades e competências relacionadas a essas áreas do conhecimento darão base ao indivíduo para que outras possam ser consolidadas por ele, não apenas na escola, mas ao longo da vida.

Kleiman (1995) entende a escola como a mais importante das "agências de letramento", mas assinala que ela se preocupa apenas com um tipo de prática de letramento, no caso, a alfabetização, sem foco nas práticas sociais da leitura e da escrita. Partindo dessa premissa, entendemos que as práticas pedagógicas que envolvem a leitura e a escrita devem transcender os processos de aquisição do código: é necessário que, aliadas ao ensino de codificar e decodificar símbolos e letras, apontem aos educandos a função social da escrita.

Segundo Soares (2007, p. 15-16), alfabetização é o “[...] processo de aquisição do código escrito, das habilidades de leitura e escrita". A autora salienta que alfabetização é um processo de representação de fonemas em grafemas e vice-versa, mas também é um processo de compreensão/expressão de significados por meio do código escrito. No entanto, destaca que ele não tem um caráter meramente instrumental, 
mas corresponde a um saber privilegiado e específico. Sobre letramento, ou alfabetismo, ${ }^{2}$ Soares (2007, p. 33) nos revela que

[...] não é apenas, nem essencialmente um estado ou condição pessoal; é, sobretudo, uma prática social [...] é o que as pessoas fazem com as habilidades e conhecimentos de leitura e escrita em determinado contexto, e é a relação estabelecida entre essas habilidades e conhecimentos e as necessidades, os valores e as práticas sociais.

Contudo, alfabetização e letramento não são práticas autônomas, indissociáveis, independentes, embora cada qual tenha sua especificidade. Assim, há de se ressaltar as palavras de Piccoli e Camini (2012, p. 20) quando salientam, a partir da perspectiva de Magda Soares, que, em se tratando de alfabetização e letramento,

[...] seria preferível conservar ambos os termos - alfabetização e letramento - por meio do reconhecimento das facetas de cada um: para letramento, a imersão das crianças na cultura escrita, a participação de experiências variadas com a leitura e a escrita, o reconhecimento e a interação com diferentes tipos de gêneros de material escrito; para a alfabetização, a consciência fonológica, a identificação das relações fonema-grafema, as habilidades de codificação e decodificação da língua escrita, o conhecimento e o reconhecimento dos processos de tradução da forma sonora da fala para a forma gráfica da escrita. Das relações entre essas facetas, com origens em processos diferentes, emerge então a ideia de alfabetizar em um contexto de letramento, ou de "alfabetizar letrando" como vem circulando amplamente.

Ao considerar que letramento ultrapassa as fronteiras escolares, é imprescindível que as práticas pedagógicas foquem em alfabetizar e letrar seus alunos para as práticas sociais nas mais diversas agências de

${ }^{2}$ Termo utilizado por Magda Soares antes de a autora dar preferência ao termo letramento. 
letramento que podem estar diretamente ligadas ao contexto dos alunos e possibilitam diferentes formas de lidar com a leitura e a escrita. Com relação às práticas de letramento no processo de alfabetização, acreditamos que as atividades de leitura e produção de texto contribuem para a construção de sentido e das funções da língua escrita, sendo um ótimo exercício para o desenvolvimento do conhecimento da língua materna.

De acordo com os Parâmetros curriculares nacionais $1^{a}$ a $4^{a}$ séries (Brasil, 1997), é importante dedicar especial atenção ao trabalho de leitura e produção de texto, mesmo antes de os alunos estarem de fato alfabetizados. Dessa forma, as práticas pedagógicas precisam proporcionar aos alunos situações reais de leitura e de escrita para que se desenvolvam no mundo letrado. Nesse sentido, as famosas HQ podem ser um valioso recurso de aprendizagem, considerando que elas estão presentes no ambiente escolar e podem estar em outros ambientes frequentados pelas crianças. Esse gênero textual é um importante instrumento para alfabetizar e letrar. As crianças demonstram grande interesse por estas histórias mesmo antes de aprenderem a ler, estando este gênero textual geralmente presente no processo de alfabetização. As ilustrações são um potencial atrativo e permitem que as crianças explorem sua interpretação subjetiva, alimentando, assim, sua fantasia.

A potencialidade pedagógica das $\mathrm{HQ}$ se relaciona também ao fato de que elas agregam ricos elementos ao processo de construção de conhecimento sobre a leitura e a escrita do leitor e escritor em formação, pois são um atrativo para os alunos e uma forma de inseri-los na cultura escrita. Ao escolher esse gênero de texto, levamos em conta seu aspecto lúdico, que pode ser facilitador da aprendizagem da leitura e da escrita. Tal peculiaridade evoca sentimento de espontaneidade e aciona a criatividade, o que pode contribuir para que o sujeito se envolva de forma prazerosa nas atividades propostas. 
Em síntese, entendemos as HQ como potencial veículo de aprendizagem. Elas despertam o interesse das pessoas em geral, por suas características lúdicas e linguísticas, pois se utilizam de texto e imagem, auxiliando no entendimento de conceitos e na ampliação de conhecimentos que, se fossem apresentados de forma isolada, provavelmente não proporcionariam aos alunos a mesma facilidade de compreensão que tal tipo de texto possibilita. Por isso, propiciar o contato dos alunos com esse gênero textual, apresentando-lhes suas características e permitindo que experimentem atividades de leitura e construção de suas próprias narrativas, pode ajudá-los nos processos de alfabetização e letramento. Ademais, sendo este um gênero discursivo de interesse dos alunos, aumenta a possibilidade de haver um processo significativo de aquisição da leitura e da escrita, uma vez que o objeto de estudo é acessado pelo indivíduo de forma prazerosa.

\section{APRENDIZAGEM SIGNIFICATIVA}

Outro grande desafio do professor é adaptar a prática ao contexto dos alunos, tornar as aprendizagens significativas para a realidade deles, atender as suas necessidades, na medida do possível, fazendo com que aprendam e construam conhecimento. Nesse sentido, existe a necessidade de conhecer bem os educandos e atentar para a forma como aprendem a fim de planejar e propor atividades que valorizem seus conhecimentos prévios para construírem estruturas mentais que os auxiliem na compreensão de novos conceitos, nos processos de aprendizagem.

Nessa perspectiva, a teoria da aprendizagem de Ausubel (1982) nos diz que a aprendizagem significativa consiste num processo de ensino que precisa fazer sentido para o educando, ou seja, a nova informação deve ancorar-se nos conceitos relevantes já existentes na sua estrutura cognitiva, sendo esta uma condição imprescindível para a aquisição de novos conceitos, para a efetivação de aprendizagens. As interações 
significativas são, então, de suma importância para que o sujeito interprete, relacione e compare informações de modo a construir conhecimento. De acordo com Ausubel, Novak e Hanesian (1980, p. 34),

A essência do processo de aprendizagem significativa é
que as ideias expressas simbolicamente são relaciona-
das às informações previamente adquiridas pelo aluno
através de uma relação não arbitrária e substantiva (não
literal). Uma relação não arbitrária e substantiva signi-
fica que as ideias são relacionadas a algum aspecto rele-
vante existente na estrutura cognitiva do aluno, como,
por exemplo, uma imagem, um símbolo, um conceito
ou uma proposição. A aprendizagem significativa pres-
supõe que o aluno manifeste uma disposição para a
aprendizagem significativa - ou seja, uma disposição
para relacionar, de forma não arbitrária e substantiva,
o novo material à sua estrutura cognitiva - e que o
material aprendido seja potencialmente significativo [...].

Nesse sentido, a aprendizagem de conceitos, ou seja, a construção de conhecimento é o foco da escolarização e não está baseada num processo de transmissão que ocorre do professor para o aluno ou da tecnologia para o aluno. É preciso que o sujeito aja sobre o objeto do conhecimento para que a significação se estabeleça.

A disposição para a aprendizagem requerida nesse processo vai ao encontro da percepção de Santos (2008, p. 62) quanto à aprendizagem significativa, que, segundo o autor, é “[...] aquela que ocorre a partir do surgimento de um sentido pessoal por parte daquele que aprende, o que desencadeia uma atitude proativa que tenta desvendar o novo e (re)construir conceitos que ampliam cada vez mais a habilidade de aprender". Em contrapartida, e ponderando que no processo de aprendizagem é preciso haver mais do que a disposição do aluno, Ausubel, Novak e Hanesian (1980, p. 34) enfatizam que 
[...] não importa se a disposição do aluno está dirigida para a aprendizagem significativa, pois nem o processo nem o produto da aprendizagem serão significativos se a tarefa da aprendizagem não for potencialmente significativa, ou seja, se não puder ser incorporada à estrutura cognitiva através de uma relação arbitrária e substantiva.

Com isso, compreendemos que a aprendizagem, levando-se em consideração a disposição para a mesma pelo aluno, deriva do pensar e construir conhecimento a partir da informação acessada e ancorada nos conceitos já existentes na estrutura cognitiva do aluno. Tal processo requer, ainda, um material potencialmente significativo, ou seja, um objeto de conhecimento potencialmente significativo, uma proposta pedagógica de fato significativa.

\section{NIVEIS DE DESENVOLVIMENTO}

Pensando em aprendizagem significativa em um contexto coletivo, em prol do desenvolvimento dos alunos, valemo-nos das ideias de Vygotsky (1998) quanto aos processos mentais superiores, tais como linguagem, leitura e escrita, dentre outros, que são potencialmente influenciados pelas interações sociais e culturais, de acordo com Sarmento (2008). Assim, entendemos que, em um contexto escolar, o professor, como integrante de tal contexto, é uma figura importante para tais processos a fim de que ocorra o contato com o conhecimento científico e, também, as interações significativas, imprescindíveis para o desenvolvimento dos educandos.

Análogo à questão dos processos mentais dos alunos, para a qual continuamos a destacar ideias de Vygotsky (1998) no que diz respeito a níveis e zonas de desenvolvimento, o que se soma a esse estudo, salientamos que, de acordo com o teórico, define-se como nível de desenvolvimento real de um indivíduo o nível das funções mentais, que seriam os ciclos de desenvolvimento já completados, ou seja, aquilo 
que a criança já consegue realizar por si mesma, com autonomia, sem nenhuma intervenção do meio. Há também o nível de desenvolvimento potencial, que se refere àquilo que a criança faz, a princípio, com o auxílio do outro, com intervenções do meio, através de interação, coletivamente. Já a zona de desenvolvimento proximal

\begin{abstract}
[...] é a distância entre o nível de desenvolvimento real, que se costuma determinar através da solução independente de problemas, e o nível de desenvolvimento potencial, determinado através da solução de problemas sob a orientação de um adulto ou em colaboração com companheiros mais capazes. (Vygotsky, 1998, p. 112).
\end{abstract}

Assim, a zona de desenvolvimento proximal envolve as funções mentais que estão em processo de maturação. Dessa forma, entendemos que a ação pedagógica deve levar em conta os processos de maturação já completos e atentar, também, para os processos mentais que só podem ser realizados pelos alunos com a ajuda de outros. Isso é fundamental para a proposição de tarefas de aprendizagem que contribuam para que o nível de desenvolvimento potencial de hoje seja o nível de desenvolvimento real de amanhã, ou seja, que propicie a maturação das funções mentais.

Com isso, salientamos que o investimento do docente em atividades de produção textual, independentemente do gênero, pode possibilitar avanços significativos no processo de alfabetização e letramento. Assim, um aluno que inicialmente consegue realizar leituras e produções textuais apenas com ajuda do professor e de suas intervenções, ou também com o auxílio da interação com os colegas poderá, posteriormente, realizá-las com autonomia e, tão logo isso ocorra, terá amadurecido a compreensão sobre a mecânica e as funções da leitura e da escrita. 


\section{O COMPUTADOR COMO RECURSO DE APRENDIZAGEM}

Ao considerar a estrutura da sociedade, não há como negar o importante papel das Tecnologias da Informação e Comunicação (TIC) na escola, sendo o ambiente escolar um grande responsável pelo crescimento humano e social. Assim, é notável a relevância da apropriação de elementos da tecnologia em favorecimento ao desenvolvimento da sociedade. Entretanto, Sette [200-] nos diz que a

[...] inserção do uso das TIC no cotidiano escolar deve ser tratada com atenção, requerendo apropriação dos instrumentos, conhecimento de seu potencial, clareza de seu papel, responsabilidade na proposição, participação da comunidade interna e externa à escola e compromisso, de todos os envolvidos no processo, na busca de uma educação com qualidade social.

Nesse sentido, entendemos que o uso dos recursos das TIC pode ir ao encontro de uma educação de qualidade, na medida em que se compreende que essas tecnologias são importantes no processo de ensino e aprendizagem e que auxiliam no desenvolvimento individual e social dos sujeitos envolvidos. Dessa forma, uma vez que as TIC são exploradas como recurso, não podem ser encaradas como protagonistas neste processo. Assim, concordamos com Moran, Masseto e Behrens (2000, p. 139) quando mencionam que

A tecnologia apresenta-se como meio, como instrumento para colaborar no desenvolvimento do processo de aprendizagem. A tecnologia reveste-se de um valor relativo e dependente desse processo. Ela tem sua importância apenas como instrumento significativo para favorecer a aprendizagem de alguém. Não é a tecnologia que vai resolver o problema educacional no Brasil. Pode colaborar, no entanto, se for usada adequadamente, para o desenvolvimento educacional de nossos estudantes. 
Dessa forma, consideramos que, para os processos de ensino e aprendizagem serem de qualidade, é necessário mais do que um espaço informatizado na escola. A informática ligada à educação, no caso a informática educativa, requer uma prática que leve o aluno a aprender e a se desenvolver com o apoio de seus recursos, sem se limitar ao ensino do manuseio de tais recursos. Ao pensar práticas sociais de uso das tecnologias, há de se levar em conta a potencialidade dessas tecnologias para além da forma de utilizá-las, pois é possível mediar seu uso para o amadurecimento dos processos mentais dos sujeitos envolvidos, para a qualificação dos processos educacionais, para a real construção do conhecimento.

\section{ENCAMINHAMENTO METODOLÓGICO}

Tendo em vista a necessidade de uma organização na conduta investigativa, na sequência explicitamos como se deu a prática pedagógica da qual foram extraídos os elementos analisados neste capítulo à luz dos referenciais anteriormente mencionados.

A experiência envolvendo processos de leitura e construção de histórias em quadrinhos ocorreu com crianças do $2^{\circ}$ ano do ensino fundamental de uma escola da rede pública estadual localizada na cidade de Porto Alegre (Rio Grande do Sul).

No primeiro momento, foi providenciada a instalação do software a ser utilizado, no caso, o HagáQuê, nos computadores do laboratório de informática da escola em questão. Após, foi realizada observação em sala de aula dos relatos de histórias lidas em material impresso, uma vez que foi oportunizada a exploração anterior de gibis com histórias em quadrinhos, individualmente ou em pequenos grupos, a fim de que os alunos manuseassem, lessem e observassem as características do suporte e do gênero textual. Esse recurso foi utilizado como motivação prévia para as atividades seguintes. 
Em outro momento, foi feita observação de leitura de histórias em quadrinhos na tela do computador, mais especificamente no site da Turma da Mônica. ${ }^{3}$ A leitura foi iniciada pela professora com solicitação de colaboração dos alunos na continuação da mesma. Na sequência, foi explicitada a proposta de produção livre de histórias em quadrinhos - a serem realizada no software HagáQuê disponível nos computadores do laboratório de informática da escola. Foram apresentadas as ferramentas do aplicativo e passadas orientações de uso abrangentes para o coletivo. Ao longo do processo de criação das $\mathrm{HQ}$, foram feitas intervenções individuais, a fim de sanar as dificuldades mais específicas de cada aluno. Após, foram coletadas as histórias em quadrinhos produzidas pelos alunos no software HagáQuê. Por fim, as HQ foram devolvidas aos alunos de forma impressa.

\section{ANÁLISE DA EXPERIÊNCIA}

Expomos, aqui, apoiados no referencial teórico já delineado, a análise realizada sobre a experiência envolvendo construção de histórias em quadrinhos por alunos de $2^{\circ}$ ano em ambiente informatizado. A análise se desenvolve de forma a evidenciar as descobertas realizadas, bem como os sucessos e as dificuldades encontradas.

Tanto a proposição de leitura quanto a de produção de texto envolvendo HQ foram realizadas com o intuito de possibilitar experiência diversificada aos alunos, permitindo sua imersão na cultura escrita e levando-se em conta a importância de alfabetizar em contexto de letramento, o que vai além da aquisição do código escrito. Atividades de leitura e escrita, em geral, tendem a contribuir para a assimilação das funções da língua escrita pelos alunos, estando eles alfabetizados ou não.

A realização de leitura de HQ, tanto em suporte gibi quanto no computador, foi de grande importância como elemento motivador para o

\footnotetext{
${ }^{3}$ Disponível em: <http://www.monica.com.br/comics/seriadas.htm>.
} 
posterior início do processo de construção das HQ pelos alunos. Foi um momento que possibilitou a percepção sobre a apropriação que os educandos já tinham sobre o sistema de escrita. No entanto, mesmo os que não liam ainda ou não o faziam com fluência puderam expressar sua compreensão das histórias apoiados na interpretação do conteúdo visual das HQ. Entendemos esta como uma prática muito importante e rica para a aquisição da leitura e compreensão das funções do código escrito, uma vez que possibilita o contato e gera familiaridade dos educandos com suporte e gênero de texto, transcendendo, assim, os limites da mecânica da leitura e da escrita.

O envolvimento das crianças na produção de suas histórias nos mostrou que a dimensão lúdica de tal gênero textual tende a apoiar o processo de aprendizagem do código escrito, uma vez que os alunos podem se experimentar como autores, praticando a construção de narrativas.

Ao observarmos suas produções e o processo como um todo, ficou evidente que as crianças estavam em níveis de desenvolvimento diferentes, o que implicou intervenções diferenciadas. Algumas já conseguiam expressar na escrita suas ideias com autonomia, outras ainda não dominavam a mecânica da escrita, mas ainda assim conseguiam expressar-se, mesmo que necessitassem de auxílio para fazê-lo.

Mesmo compreendendo que a experiência vivida teve sua riqueza naquele contexto escolar, é importante admitir que a construção da narrativa propriamente dita foi uma das dificuldades encontradas nessa prática pedagógica, tanto pelos alunos quanto pelas professoras envolvidas. Ainda que percebamos o grande interesse dos alunos pelo gênero textual HQ, há de se considerar que são necessárias mais propostas atrativas e materiais potencialmente significativos que propiciem experiências diversas de imersão dos alunos na cultura escrita. Propor uma criação livre em um primeiro momento, em uma primeira experiência unindo HQ e informática, foi prazeroso para as crianças, mas talvez uma 
proposta mais dirigida e específica para o grupo pudesse ter proporcionado uma aprendizagem mais qualitativa por parte dos educandos sobre a estrutura de uma narrativa, além de contribuir para a melhor fluidez do processo de construção de HQ no ambiente informatizado.

Para uma proposta adequada a uma experiência envolvendo construção de narrativa em HQ, é muito importante a compreensão dos docentes envolvidos sobre esse tipo de narrativa. Isso é fundamental para que tenham mais elementos e possam fornecer instruções explícitas sobre a estrutura de tal gênero de texto, realizando intervenções significativas a fim de ajudar os alunos na produção de HQ bem elaboradas, sem intervir no processo de autoria, ou seja, no processo de expressão de ideias de cada um.

O material potencialmente significativo escolhido para a experiência aqui mencionada - o recurso tecnológico HagáQuê - mostrou-se apropriado para o contexto em questão e foi bem explorado pelos alunos para a autoria de suas HQ, mesmo com os contratempos ocasionados pelas dificuldades técnicas. No entanto, para uma proposta mais abrangente do que a lançada para os alunos, ou mesmo para uma proposta com temática mais restrita e específica, seria preciso enriquecer o acervo de imagens, de modo que os educandos tivessem mais opções a explorar na composição de sua narrativa.

É importante salientar que os alunos demandavam muita atenção, o que, somado às problemáticas com o HagáQuê e com os equipamentos em geral e ao pouco tempo para a realização da experiência, impactou no andamento do processo e, consequentemente, na disponibilidade das professoras para atendê-los de forma mais qualificada. Frente às problemáticas e aos imprevistos, percebemos a importância de os docentes se valerem de outras estratégias de modo a flexibilizar o que já está organizado e planejado. Alguns conhecimentos técnicos e uma maior intimidade do educador com as tecnologias também podem auxiliar muito no 
andamento das tarefas de aprendizagem com o computador, pois muitas dificuldades podem ser encontradas durante a realização de tais tarefas.

Independentemente das dificuldades e dos contratempos, acreditamos que a experiência tenha sido válida e significativa para todos, uma vez que possibilitou atividade de autoria na qual os alunos puderam refletir sobre a mecânica da escrita e as características das narrativas em histórias em quadrinhos. Exercitaram, assim, os conhecimentos já consolidados e os conhecimentos ainda em construção, ou seja, as estruturas mentais ainda em processo de amadurecimento. Dessa forma, as HQ se confirmaram como um potencial recurso pedagógico, atraindo os alunos e proporcionando acesso à cultura escrita através da produção de práticas de autoria de forma prazerosa, espontânea e criativa, como se deu com o grupo de alunos do $2^{\circ}$ ano.

Mesmo tendo sido a primeira experiência com recursos da tecnologia em ambiente escolar para todos os envolvidos, foi possível compreender a potencialidade e a importância das TIC como recurso pedagógico em prol de tarefas de aprendizagem inovadoras, desafiadoras, significativas. Nesse sentido, consideramos que o uso do ambiente informatizado da escola e de um software para construção de HQ não foi a finalidade da prática pedagógica, mas um meio com a ajuda do qual tal prática se fez significativa no contexto mencionado.

Dessa forma, acreditamos no potencial significativo da proposta realizada envolvendo produção de HQ em ambiente informatizado, já que privilegiou os conhecimentos prévios das crianças e possibilitou interações significativas, contando com material relevante, no caso a tecnologia, e com a disposição do aluno para o desenvolvimento de uma tarefa de autoria com sentido próprio para cada autor - tarefa de expressão de ideias. Essa disposição se converteu em satisfação no momento final, no qual puderam se apossar de suas produções, inclusive de forma impressa para guardarem consigo. Isso só faz reforçar a importância de 
investimento em tarefas que explorem a leitura e a produção textual com o computador como recurso, tarefas essas que podem proporcionar avanços significativos e qualitativos no processo de alfabetização e letramento.

\section{CONSIDERAÇÕES FINAIS}

Ao iniciar a produção do presente trabalho, tendo como foco principal as relações entre informática e educação, mais especificamente os processos de alfabetização e letramento apoiados por recursos de tecnologia, elaboramos a seguinte questão a ser respondida: Pode a prática pedagógica envolvendo o computador como recurso de aprendizagem contribuir para os processos de alfabetização e letramento dos alunos?

Ao longo da experiência vivida e da análise realizada, e com base nelas, foi possível delinear prováveis respostas a esta questão, começando pela nossa percepção de que se pode aliar o uso do computador aos processos de alfabetização e letramento, significando-os através de propostas atrativas e motivadoras para que os alunos se sintam participantes importantes no processo de construção do seu próprio conhecimento. Buscamos, assim, a expressão das ideias dos aprendizes em produções de sua autoria. Tornar uma experiência, envolvendo alfabetização e letramento e o computador como recurso de aprendizagem, prazerosa e significativa é um dever e, ao mesmo tempo, algo desafiador para o professor contemporâneo, mas torna-se possível na medida em que o docente abre mão de seus receios para encarar os desafios impostos, buscando conhecer e refletir sobre sua prática em prol de um processo de ensino de qualidade.

Ao longo do percurso, pudemos entender que é importante proporcionar diferentes formas de lidar com a leitura e a escrita e suas funções. As práticas pedagógicas que envolvem tais conhecimentos podem transcender os processos de aquisição do código, promovendo a imersão dos alunos na cultura escrita através de atividades de autoria. 
Nesse sentido, as HQ se afirmam como potencial recurso pedagógico para a construção do conhecimento sobre a escrita e suas funções e a utilização do software HagáQuê agregou muito à experiência.

As interações significativas tendem a auxiliar nos processos mentais dos alunos, sendo de suma importância para que as aprendizagens se efetivem, e, consequentemente, os alunos se desenvolvam. Considerando o ambiente escolar, tais interações devem contar com intervenções intencionais do docente com o intuito de propiciar aos educandos o amadurecimento de suas estruturas cognitivas e o avanço no processo de construção do conhecimento.

Foi possível, através da análise da experiência em questão, ter mais clareza sobre o papel e o potencial dos recursos tecnológicos em processos educativos no sentido de apoiar as mais diversas práticas pedagógicas. O computador deve ser utilizado como recurso, como instrumento potencialmente significativo para a promoção de aprendizagens, tendo em vista que o que tornará a prática significativa não será o recurso, mas o processo como um todo. As tecnologias por si só não têm o poder de significar o processo de aprendizagem, uma vez que não planejarão, não buscarão conhecer os alunos para saber o que sabem e como pensam, não procurarão tornar a experiência prazerosa e significativa para os educandos em seu respectivo contexto e não se preocuparão com o desenvolvimento integral dos sujeitos envolvidos. Contudo, a utilização dos recursos tecnológicos é um saber social importante de ser abarcado nos processos de ensino e aprendizagem. Dessa forma, sendo a proposta atrativa, a tarefa de aprendizagem e as interações significativas para os envolvidos e os recursos das TIC utilizados de modo adequado, provavelmente os resultados do processo vivenciado serão satisfatórios.

Através do contato com o software utilizado constatamos que a flexibilização do acervo de imagens, balões, sons e cenários é possível e pode 
proporcionar uma infinidade de propostas que explorem a criatividade dos educandos e promovam aprendizagens. No entanto, para que tal flexibilização ocorra, é preciso que o educador tenha certa intimidade com o recurso e não que se sinta intimidado ao lidar com ele. O professor precisa se permitir conhecer o recurso e explorá-lo, para poder oportunizar aos alunos experiências satisfatórias com a ferramenta.

Salientamos que o receio do uso das tecnologias não pode ser maior do que a importância de incluí-las nas práticas pedagógicas, pois, além de serem ferramentas importantes para a vivência social dos sujeitos envolvidos, podem propiciar experiências relevantes com relação aos processos de alfabetização e letramento e nas diversas áreas do conhecimento. Assim, percebemos que os educadores devem buscar conhecer o papel e o potencial dos recursos das TIC para utilizá-los para qualificar sua prática.

Enfatizamos também a importância de se regular o manuseio dos componentes do computador pelas crianças, tais como o teclado, por exemplo, no sentido de instruí-los sobre a forma adequada de digitação, o que certamente irá facilitar e aperfeiçoar as práticas envolvendo o uso desse recurso pelos educandos.

A experiência nos mostrou a importância das práticas de leitura e escrita mediadas pelo uso do computador como recurso, considerando que esse tipo de vivência pode proporcionar aprendizagens que são extremamente necessárias na contemporaneidade, se considerarmos o desenvolvimento integral dos sujeitos envolvidos. Assim como é fundamental a imersão dos educandos na cultura escrita, faz-se necessária sua imersão na cultura tecnológica que está presente na nossa sociedade.

Ressaltamos ainda que tal experiência nos possibilitou grandes reflexões e muitas aprendizagens. Nesse sentido, não desmerecendo o uso dos recursos tecnológicos, em absoluto, enaltecemos a importância 
e a responsabilidade do professor nos processos de construção do conhecimento. É preciso pensar em todos os elementos que envolverão o processo, considerando: os níveis de desenvolvimento dos educandos; os materiais potencialmente significativos, no caso os recursos a serem utilizados; a tarefa potencialmente significativa; e a meta a ser atingida. Ao mencionar "potencialmente significativo", entendemos que há uma possibilidade, não uma realidade. Entretanto, na medida em que os elementos se combinam, existe a possibilidade de tornar o processo realmente significativo, para que se efetivem aprendizagens e desenvolvimento.

Para concluir, enfatizamos a necessidade de que estratégias de ensino envolvendo práticas pedagógicas apoiadas pelos recursos tecnológicos sejam mais exploradas nos cursos de formação de professores, para que estes se apropriem cada vez mais desse saber social de forma a utilizá-lo para somar a suas práticas e qualificar os processos de ensino e aprendizagem.

\section{REFERENNCIAS}

AUSUBEL, D. P. A aprendizagem significativa: a teoria de David Ausubel. São Paulo: Moraes, 1982.

AUSUBEL, D. P.; NOVAK, J. D.; HANESIAN, H. Psicologia educacional. 2. ed. Rio de Janeiro: Interamericana, 1980.

BRASIL. Ministério da Educação. Secretaria de Educação Básica. Parâmetros curriculares nacionais $1^{a}$ a $4^{a}$ série, Brasília: MEC. 1997.

KLEIMAN, A. B. Modelos de letramento e as práticas de alfabetização na escola. In: KLEIMAN, A. B. (Org). Os significados do letramento: uma nova perspectiva sobre a prática social da escrita. 3. ed. Campinas: Mercado de Letras, 1995. p. 15-61.

MORAN, J. M.; MASSETTO, M. T.; BEHRENS, M. A. Novas tecnologias e mediação pedagógica. 10. ed. Campinas: Papirus, 2000. 
PICCOLI, L.; CAMINI, P. Práticas pedagógicas em alfabetização: espaço, tempo e corporeidade. Erechim: Edelbra, 2012.

SANTOS, J. C. F. Aprendizagem significativa - modalidades de aprendizagem e o papel do professor. Porto Alegre: Mediação, 2008.

SARMENTO, D. F. A teoria histórico-cultural de L. S. Vygotsky e suas contribuições para as práticas educativas. In: SARMENTO, D. F.; RAPOPORT, A.; FOSSATTI, P. (Org.). Psicologia e Educação: perspectivas teóricas e implicações educacionais. Canoas: Salles, 2008. p. 27-43.

SETTE, S. S. A tecnologia construindo uma escola cidadã. TV Escola - Salto para o futuro. [200-]. Disponível em: <http://moodle3.mec.gov.br/unir/file. php/1/A_tecnologia_contribuindo_para_uma_escola_cidada.pdf $>$. Acesso em: 13 mai. 2013.

SOARES, M. Alfabetização e letramento. 5. ed. São Paulo: Contexto, 2007.

VYGOTSKY, L. S. Formação social da mente: o desenvolvimento dos processos psicológicos superiores. 6. ed. São Paulo: Martins Fontes, 1998. 


\section{Leitura do jornal, leitura do mundo:} reflexões sobre uma prática de letramento numa turma de alfabetização de jovens $e$ adultos Bruna da Cunha Fagundes

O presente artigo retoma realidades e concepções analisadas em pesquisa qualitativa de caráter participante originada de minha experiência como estagiária em uma turma de alfabetização de jovens e adultos (EJA) de uma escola da rede municipal de Porto Alegre.

Nessa turma, realizei uma experiência de docência compartilhada com a professora titular, que propôs a realização de um projeto de letramento envolvendo o uso do jornal. As dinâmicas do projeto variavam de acordo com o propósito que se pretendia atingir: leitura individual e/ou coletiva, que possibilitava o desenvolvimento de estratégias de leitura; procura de palavras na capa do jornal, que permitia fazer relações entre o texto e o contexto; produção de manchetes a partir das reportagens, que evidenciava os saberes dos educandos sobre as funções da escrita e, ainda, instigava a reflexão crítica sobre o que liam. Para tanto, o jornal era entregue na íntegra para cada educando com o intuito de 
que se apoderassem do material escrito, explorando-o em sua totalidade, tanto em sala de aula quanto, e principalmente, no mundo.

O encantamento com as diferentes possibilidades de leitura do jornal e com os princípios teóricos embasados nos ensinamentos de Paulo Freire me motivaram a indagar: de que modo esse projeto de letramento escolar, envolvendo o uso do jornal, contribui para a apropriação da língua escrita, para a reflexão crítica sobre o mundo e para a ampliação das práticas sociais de leitura e escrita dos educandos jovens e adultos de uma turma de alfabetização? Para responder à questão, foi realizada uma análise do diário de classe, produzido durante o estágio, bem como do diário de campo, produzido posteriormente. Foram enfocados seis encontros nos quais utilizei a técnica de observação participante do mesmo grupo de alfabetizandos com que trabalhei durante o período de estágio.

Com o tempo, fui percebendo os sentidos da prática para aqueles educandos jovens e adultos. A partir de suas falas e atitudes, percebi o quanto eles se fortalecem como sujeitos e cidadãos ao se apropriarem de um símbolo da cultura escrita, fazendo uso do jornal que, a priori, não é produzido para aqueles que não dominam a leitura. Assim como Paulo Freire (2006), acredito que a partir da leitura os sujeitos devem ser capazes de refletir sobre o mundo em que vivem, para que este possa ser reescrito por eles, sendo o ato de ler e escrever, nessa perspectiva, uma forma de empoderamento ${ }^{1}$ dos sujeitos.

O conceito de letramento se refere aqui ao uso social que se faz da leitura e da escrita, aproximando-se dos princípios freireanos. Ambos

${ }^{1}$ Empoderamento é a tradução do termo empowerment discutido por Henry Giroux em "Alfabetização e a pedagogia do empowerment político", texto introdutório ao livro Alfabetização: leitura da palavra, leitura do mundo, de Paulo Freire e Donaldo Macedo (2011). Ele é entendido como a forma com que os sujeitos das classes populares se potencializam, individual e coletivamente, enquanto um grupo social específico, através da reflexão crítica de sua realidade, bem como da conscientização acerca dos mecanismos de exclusão e discriminação da sociedade. 
são capazes de transcender o ensino das habilidades técnicas do ler e escrever, o que considero de suma importância para a formação dos educandos que frequentam a EJA, pois urge a esses sujeitos participar das práticas de letramento disponibilizadas pela sociedade. Em diversos momentos durante o estágio, pude notar nos educandos essa necessidade de utilizar a leitura e a escrita. Tanto eu quanto a professora titular éramos procuradas para atender demandas cotidianas, como ler um encaminhamento dado pelo posto de saúde, no caso das idosas.

Para compreender a perspectiva de letramento inserida nesse projeto, foi necessário me debruçar sobre os estudos que tratam dessa temática. Apesar de recente no Brasil, ela vem sendo discutida por diversos autores sob óticas diferentes. Considerando a complexidade do termo e suas diferentes interpretações, passamos para um breve histórico sobre o tema, abordando também suas perspectivas e, por fim, sua relevância para as práticas de sala de aula em turmas de EJA.

\section{LETRAMENTO: SUAS VERTENTES $\varepsilon$ POSSIBILIDADES}

\section{NA ALFABETIZAÇÃO DE ADULTOS}

\section{um breve histórico sobre o letramento}

Os registros da palavra letramento no Brasil surgiram em meados dos anos 80. Segundo Soares (2010, p. 56), "Durante mais de 500 anos de existência deste país, nós nos satisfizemos com a palavra alfabetização: não existia em nosso léxico a palavra letramento". O surgimento dessa palavra se relaciona à falta de um termo que explicasse um fenômeno percebido naquele momento: a condição - para além do saber, ou não, ler e escrever - que compreendia a incorporação desses saberes no viver de cada sujeito.

Embora tenha emergido de uma demanda social, essa palavra não foi inventada por brasileiros, ela foi traduzida do termo inglês literacy. O termo chega ao Brasil como amparo teórico para se compreender 
um fenômeno cultural, os modos e as condições com que a sociedade brasileira lida com a escrita, mas também como sustentação metodológica para o ensino da leitura e da escrita. Soares (2010) afirma que aqui o termo surgiu em estreita relação com o conceito de alfabetização. É interessante que, ao mesmo tempo que a chegada do termo "letramento" anunciava o caráter político e ideológico da alfabetização e das práticas sociais de leitura e escrita, a alfabetização ganhava força, no seu caráter linguístico, quando unida ao letramento.

Os Novos Estudos sobre o Letramento (NLS, do inglês New Literacy Studies) articulados por Brian Street (2010) têm como perspectiva conceitual o modelo ideológico. Esse modelo, segundo Marinho (2010), tem exercido bastante influência no Brasil devido à sua aproximação com o pensamento de Paulo Freire, caracterizado por fundamentos políticos e sociais com relação à alfabetização, à leitura e à escrita.

Essa breve retomada evidencia a perspectiva educacional em relação aos estudos sobre o letramento no Brasil, assim como salienta sua íntima relação com a alfabetização e com os NLS. Essa indissociabilidade dos temas me motiva a visitar, na próxima subseção, algumas perspectivas teóricas acerca dos conceitos de letramento e alfabetização.

\section{Conceitos de letramento $e$}

\section{alfabetização: perspectivas teóricas}

Para melhor compreender os conceitos de letramento e alfabetização que permeiam este estudo, faço uma breve aproximação das perspectivas teóricas sobre alfabetização e letramento abordadas por Angela Kleiman e Leda Tfouni.

Para Kleiman (2012, p. 11), “[...] letramento é considerado um conjunto de práticas sociais, cujos modos específicos de funcionamento têm implicações importantes para as formas pelas quais os sujeitos envolvidos nessas práticas constroem relações de identidade e poder". 
Em outra obra, Kleiman (2007, p. 1) discorre sobre práticas de letramento na escola, abordando essas relações de identidade e poder: "O letramento tem como objeto de reflexão, de ensino ou de aprendizagem os aspectos sociais da língua escrita. Assumir como objetivo o letramento no contexto do ciclo escolar implica adotar na alfabetização uma concepção social da escrita [...]”. Assumir esse posicionamento implica, segundo a autora, proporcionar uma aprendizagem significativa, por meio de textos que sejam dotados de sentido para os educandos, considerando suas bagagens culturais, pois antes de chegarem à escola já participam de práticas sociais de leitura e escrita.

Na perspectiva de Leda Tfouni, em uma sociedade moderna, marcada pelo avanço científico e tecnológico, e onde a escrita está presente em todo o contexto social, é impossível afirmar que existem pessoas iletradas. Esse argumento está fundamentado numa visão sócio-histórica a partir da qual Tfouni (1995, p. 56) assinala que, “[...] em um mesmo momento histórico, não se pode afirmar que todas as pessoas estejam no mesmo nível de desenvolvimento. Do ponto de vista do letramento, pode se pensar em um eixo". Nesse eixo, nomeado de continuum, encontram-se, de um lado, os menos letrados, de outro, os mais letrados, os quais teriam também se apropriado do processo de alfabetização e mesmo o ultrapassado, em diferentes níveis. Essa proposta permite alternância e transformações nas várias gradações possíveis de letramento, dependendo do ponto de partida histórico e social em que os sujeitos se encontram, pois considera as desigualdades da sociedade.

Segundo a autora, "[...] letramento é apresentado como um fenômeno sócio-histórico e investigá-lo implica estudar as transformações que ocorrem em uma sociedade quando suas atividades passam a ser permeadas por um sistema de escrita cujo uso é generalizado" (Tfouni, 1995, p. 55). Em síntese, partimos do pressuposto de que não existem iletrados numa sociedade grafocêntrica e, ainda, de que há letramento antes da alfabetização e sem alfabetização. Para Tfouni (1995), a ideologia 
também é atrelada ao conceito de letramento, cuja discussão se engendra na distribuição social de sentidos produzidos nos discursos escritos. A autora busca relacionar o quanto esses discursos são "poderosos", uma vez que até a forma de um texto molda um leitor ao impedir livres interpretações, como, por exemplo, o uso das notas de rodapé, que direcionam a interpretação para onde o autor deseja. Tfouni (1995) aprofunda a reflexão relativamente ao lugar da ideologia nas práticas de letramento ao destacar o quanto esses discursos, espécie de porta-vozes do conhecimento das sociedades letradas, são distribuídos socialmente de forma desigual. Os pobres, os analfabetos, mesmo estando inseridos nessa sociedade e possuindo certo grau de letramento, são colocados à margem dessa distribuição de conhecimento.

A partir destas proposições, reporto-me à prática de letramento envolvendo a leitura do jornal e a reflexão em torno dele com educandos não alfabetizados, mas que estão em diferentes níveis de letramento. Parece-me que o jornal também representa essa distribuição social desigual tanto do conhecimento quanto das práticas sociais que excluem aqueles que não dominam a leitura e a escrita. Penso que seu uso em sala de aula possibilitou a inversão desse processo de exclusão, pois, com o tempo, os educandos foram se apropriando, tanto do seu discurso, o que foi possibilitado pelas reflexões críticas, quanto do objeto jornal, o que foi propiciado pela leitura da palavra.

A prática de leitura do jornal também ratifica a defesa de Kleiman dos projetos de letramento. $\mathrm{O}$ jornal, além de ser um material escrito de grande circulação na sociedade, possui informações que correspondem à realidade de vida dos educandos e, ainda, ajuda a romper com as relações de poder traduzidas pelo discurso e pelo próprio uso deste suporte de leitura, conforme podemos observar nas palavras de Kleiman (2010, p. 238) os projetos de letramento representam: 
[...] um conjunto de atividades que se origina de um interesse real na vida dos alunos e cuja realização envolve o uso da escrita, isto é, a leitura de textos que, de fato, circulam na sociedade e a produção de textos que serão lidos, em um trabalho coletivo de alunos e professor, cada um segundo sua capacidade.

As reflexões teórico-práticas acerca do tema letramento na EJA e de suas implicações para o processo de alfabetização desses educandos serão analisadas na sequência deste artigo.

\section{LEITURA DA PALAVRA, APROPRIAÇÃO DA LINGUA ESCRITA \& ESTRATÉGIAS DE LEITURA}

Essa subseção tratará diretamente da aprendizagem da língua escrita com o propósito de investigar de que forma a prática de letramento, envolvendo o uso do jornal, pode contribuir de modo a que ocorram avanços na apropriação da língua em função do trabalho com estratégias de leitura junto aos educandos da EJA. Para tanto, procuro elucidar aspectos da concepção sociopsicolinguística de leitura a partir dos estudos de Silvia Braggio (1992) e, posteriormente, tomo como ponto de partida as semelhanças entre esse modelo e os estudos de Martha Kohl de Oliveira $(1993 ; 2007)$ que relacionam a cultura aos modos de pensamento.

No modelo sociopsicolinguístico, a autora cita exemplos de estratégias cognitivas que os leitores desenvolvem com base em todos os conhecimentos possíveis para entender o texto e seus significados. A primeira estratégia seria a decisão de ler com determinada intenção. A segunda se refere ao mapeamento do input gráfico, ou seja, a seleção do que se quer ler no material escrito. A terceira estratégia é a inferência, isto é, a capacidade de compreender algo que não está explícito no texto. A quarta é a predição, habilidade de antecipar o que está vindo em seguida. Confirmar ou não confirmar é a quinta estratégia: o leitor verifica a consistência da nova informação com suas inferências e predições. A sexta 
estratégia se refere à correção, ou seja, é usada para reconstruir o texto e retomar o significado quando este não for confirmado. Por fim, a terminação, uma intenção de findar o ato de ler.

As estratégias operam dinamicamente na procura do significado e estão direcionadas para o entendimento do texto. Embora elas estejam continuamente disponíveis, algumas ocorrem mais comumente do que outras em certos pontos da leitura. Essa procura do significado é o que mobiliza o leitor a utilizar tais estratégias, sendo este um dos aspectos mais salientes desse modelo teórico.

É possível relacionar esses estudos à proposta pedagógica de leitura do jornal, pois esta permitiu aos educandos mobilizar diferentes estratégias de leitura. As primeiras observadas se referem à intenção e seleção da leitura, facilitadas pela forma gráfica oferecida pelo jornal, que se utiliza de uma disposição de imagens e linguagem própria. A seguir, a inferência é possível em função das figuras de linguagem características das manchetes. Já a predição é facilitada, pois as informações contidas no jornal fazem parte do cotidiano desses educandos. A confirmação e a não confirmação são consequências da capacidade de realizar predições, inferências e interpretações, assim como a correção.

Para Silvia Braggio (1992), o ato de ler é considerado um processo em que a língua escrita deve ser abordada pela busca de significado, pois a compreensão deste precede a identificação de letras e palavras. Isto é, o objetivo do leitor é sempre compreender o sentido do texto; não se concentrar nas palavras e nos seus significados isoladamente. Esta afirmação corrobora o pressuposto freireano segundo o qual a leitura de mundo precede a leitura da palavra.

Nesse sentido, Braggio (1992, p. 75) afirma que “[...] o texto tem potencial para evocar significado, mas não tem significado em si mesmo. O significado é o resultado do contato do leitor com o texto, num contexto específico". Essa afirmação encontra fundamentos no que a 
autora chama de visão de leitura "transacional": o contexto da linguagem opera sobre os esquemas cognitivos, os quais direcionam a utilização das estratégias de leitura que, por sua vez, mapeiam o contexto da linguagem como se fosse um ciclo que resulta no desempenho tanto do leitor como do escritor.

Ao me reportar aos estudos de Oliveira (1993) sobre a mente humana e suas relações com a cultura, percebi que o mesmo ocorre nas investigações desenvolvidas por Braggio, pois ambas as autoras atribuem à dinâmica cultural e aos aspectos históricos e sociais as diferenças entre comportamentos cognitivos, as quais apontam para competências cognitivas diferentes em práticas culturais desiguais. Ou seja, sujeitos pouco letrados têm, muitas vezes, modos de pensamento distintos dos mais letrados, voltando-se a um saber concreto ou prático, o que pode também ser um impeditivo para a plena inserção social. Daí a apropriação de determinados domínios culturais se mostrar fundamental para a inserção plena de pessoas e grupos sociais numa sociedade em que a leitura e a escrita são onipresentes.

Além disso, é a partir dessa disparidade que a autora atribui características aos modos de funcionamento intelectual dos sujeitos com maior e menor grau de letramento. Quanto aos primeiros, as pesquisas apontam para uma maior facilidade em operar com categorias abstratas, bem como apresentam um modo de pensamento independente de vivências pessoais concretas. O contrário ocorre com os membros de grupos menos letrados, pois sua elaboração cognitiva deriva de um comportamento dirigido pela percepção, pelo contexto concreto e pela experiência pessoal.

Encontrei, nessas constatações, embasamento teórico para compreender o comportamento cognitivo observado nos estudantes da EJA, pois, sendo eles membros de grupos culturais menos letrados, é coerente que tenha percebido, no funcionamento intelectual deles, características congêneres às elencadas nos estudos de Oliveira (1993). 
Retomando o objetivo do presente capítulo, passo a analisar de que forma o projeto de letramento envolvendo o uso de jornal pode contribuir com avanços na apropriação da língua escrita pelos educandos a partir dos referenciais teóricos apresentados.

Avaliando o ambiente estabelecido nesse projeto de letramento, percebo algumas possibilidades que, unidas, favorecem avanços nos processos cognitivos e na aquisição da escrita haja vista que o cenário que se consolida é o do respeito à cultura, à linguagem e ao meio social dos educandos, ao estabelecer um espaço de diálogo suscitado pelas informações trazidas pelo jornal. Além disso, a linguagem é trabalhada de uma forma integrada, incorporando aspectos grafofônicos, sintáticos e semânticos através do contexto das manchetes e reportagens, o que favorece a busca de sentido no texto. $\mathrm{O}$ alfabetizando tem a possibilidade de utilizar seus conhecimentos prévios sobre o mundo e sobre linguagem, realizando predições e inferências e discutindo criticamente sua realidade.

Conforme o modelo sociopsicolinguístico, são essas possibilidades, presentes no contexto da prática de letramento, que vão influenciar nos esquemas mentais em processamento pelos educandos e direcionar as estratégias de leitura, conforme veremos no exemplo:

Ao realizarem a leitura da reportagem "Rua da Praia clama por manutenção", as educandas empacam na palavra "praia”. A professora solicita que se reportem à imagem anexa à manchete e a contextualiza, informando que se trata de uma rua bem famosa de nossa cidade. A aluna (79) acompanha a leitura com o dedo e faz sua predição: "É Praia?". "Correto", responde a professora. Enquanto isso, a aluna (76) se remete à palavra no jornal e diz: "É praia porque tem o P e o A". A aluna (79) comenta 
que imaginava que era essa palavra, mas teve certeza quando a professora deu a dica. A professora questiona o significado da manchete, e a aluna (76) responde: "A manutenção deve ser os fios de luz que tá tudo ruim lá na rua”. E reclama "É porque tá tudo ruim mesmo". Novamente a professora intervém: “Mas a manutenção só se refere aos fios de luz?". A aluna (79) responde: "Não, às calçadas também". A professora esclarece o sentido da palavra "manutenção" e a diferença entre "clama" e "reclama", questionando-as: "Quem é que clama? É a rua que pede manutenção?”. As educandas respondem que "Não", que "É o responsável que cuida das ruas e calçadas". A aluna (76) diz que "É o delegado do orçamento participativo" (representante eleito pela população, para organizar as demandas e intermediá-las com o poder público). (Diário de campo, 27 de maio de 2013).

Nesse exemplo, verifica-se a utilização da predição e da confirmação. A primeira é percebida no momento em que a aluna (79) prediz a palavra "praia", revelando suspeitar da presença dessa palavra desde a tentativa inicial de leitura. A confirmação foi a estratégia utilizada pela aluna (76) ao direcionar sua atenção à palavra e confirmar a predição da colega pela correspondência letra/som. Outra evidência é a dificuldade das educandas em utilizar a inferência para compreender a manchete, pois precisavam inferir que a rua necessita de manutenção. Além disso, nota-se, nas explicações, um pensamento relacionado ao contexto, visto que a aluna (76) atribui a palavra "manutenção" aos fios de luz de sua rua, bem como associa a pessoa encarregada de solicitar a manutenção ao delegado do orçamento participativo. A aluna (79) também demonstra esse modo de pensar, quando relaciona a manutenção às calçadas do caminho da escola. 
Para fazer um contraponto com as dificuldades apresentadas pelas educandas, recordo-me de uma situação de aula em que o aluno (52) utiliza a estratégia da inferência para compreender um sentido que não estava explícito no texto, a partir da seguinte manchete: "1874, Moradores tentam recuperar um dos prédios mais antigos de Porto Alegre”. Ao ser questionado pela professora sobre o que significa o número 1874 naquele contexto, o aluno (52) responde: "É a data do prédio, em que ele foi construído, porque eles querem recuperar", diferente das colegas que acreditavam ser um número referente à localização do prédio na rua, ao seu endereço.

Podemos relacionar esse contraponto aos estudos de Oliveira (1993), corroborando que há modos de pensamento diferentes, mas isso não indica uma natureza diferente desses pensamentos. As alunas associaram o número ao endereço do prédio, conhecimento mais comum da experiência vivida. Mas isso não significa que elas não tenham capacidade de realizar inferências. Provavelmente, nos campos de suas experiências, elas realizem abstrações espontâneas.

O fato é que empregar estratégias de leitura contribui com avanços no processo de leitura e de escrita e ainda pode levar os educandos jovens e adultos à apropriação de estratégias mais elaboradas. Por fim, as análises indicam que é nesse ambiente de troca, de respeito à cultura, à linguagem e ao meio social dos educandos, que promovemos oportunidades de avanço na aquisição da língua escrita, conforme os exemplos das estratégias de leitura apresentados nesse artigo.

Cabe ressaltar que o processo de alfabetização e de leitura postulado aqui não se refere apenas a um bom leitor da palavra, mas também, e principalmente, ao leitor crítico. Assim, podemos afirmar, com Braggio (1992), que esse projeto apresenta aos estudantes uma noção de linguagem essencialmente funcional e que, ao se apoderarem dela 
criticamente, têm ao alcance uma ferramenta que, em nossa sociedade, atua como instrumento de poder.

\section{LEITURA DO JORNAL, LEITURA DO MUNDO}

Nesta subseção do capítulo, analiso como a prática de letramento, envolvendo a leitura do jornal, vai contribuir com o desenvolvimento de uma atitude na qual se percebe a reflexão crítica de mundo dos educandos da EJA. Os conceitos presentes nessa análise estão embasados nos estudos de Freire (2006) sobre a relevância da leitura na alfabetização de jovens e adultos, em Henry Giroux (2011) no que se refere à perspectiva do empoderamento e em Regina Hara (1992) quanto aos desafios e possibilidades na alfabetização de adultos.

Para Freire (2006, p. 8), "[...] a leitura da palavra é sempre precedida da leitura de mundo. E aprender a ler, a escrever, alfabetizar-se é, antes de mais nada, aprender a ler o mundo, compreender o seu contexto, não numa manipulação mecânica de palavras, mas numa relação dinâmica que vincula linguagem e realidade". Inicio a reflexão com essa citação de Freire, pois percebo nela vários elementos que se relacionam ao trabalho com o jornal, posto que, nesse cenário, os educandos em processo de alfabetização empenham-se em ler o mundo em contato com a palavra oferecida pelo jornal, numa linguagem contextualizada e vinculada com a realidade. $\mathrm{O}$ jornal é o objeto que permite ler o mundo de forma contextualizada e que emoldura sentidos à palavra escrita.

Mas o que é ler o mundo? Para o autor, a leitura de mundo vem da experiência existencial dos sujeitos, que se inicia na infância e se alonga na leitura da palavra. Não da palavra pura, mas da palavra-mundo, ou seja, palavra problematizada no mundo. Desse modo, julgar, indagar e refletir acerca da realidade são exercícios necessários para lê-la. Conforme Freire (2006) é neste movimento, no qual a palavra dita flui do mundo, através da leitura que dele fazemos, que se pode ir mais 
longe, não apenas fazendo essa leitura de mundo, mas reescrevendo-o através da prática consciente.

Para Giroux (2011), a alfabetização crítica deve ser direcionada em favor do empoderamento individual e social dos grupos oprimidos, ao dar-lhes voz e ao promover o conhecimento engajado nas necessidades sociais. O empoderamento deve servir tanto para dar forma à sociedade, ampliando as possibilidades de vida e de liberdade humanas, quanto para governá-la. O autor defende a alfabetização crítica como uma precondição para o empoderamento e salienta que este não é equivalente à emancipação, mas é um processo que potencializa a capacidade de conscientização das pessoas, ampliando a possibilidade de produzir transformações. Ou seja, à medida que os grupos populares tomam consciência da realidade de opressão e das relações de poder da sociedade, também vão se empoderando, aumentando a capacidade de intervenção social. Desse modo, as ações transformadoras são resultado do processo de empoderamento quando os sujeitos das classes populares ampliam sua conscientização acerca dos mecanismos de exclusão e discriminação que de algum modo os oprimem.

Para ilustrar a leitura de mundo e a reflexão crítica realizada a partir da leitura do jornal, segue um recorte de aula extraído do diário de classe:

Iniciamos a aula lendo a manchete principal do jornal, que tratava da paralisação dos planos de saúde, assunto que despertou interesse na turma. Analisamos que se tivéssemos saúde pública de qualidade, não precisaríamos pagar planos particulares, os quais, além de cobrarem altos valores, também não garantem tal qualidade, haja vista a manifestação relatada no jornal, sendo que a fiscalização da qualidade é dever do Estado. A aluna (77) comenta que sua filha paga caro o plano de saúde dela, e, quando precisa consultar 
com urgência, tem que pagar particular, porque no plano só tem vaga para um mês depois. Comentei com o grupo que a aluna (77), ao apelar por uma consulta particular, está pagando três vezes pelo atendimento. A sala ficou em silêncio, e logo a aluna (72) perguntou: "Como assim três vezes, professora, paga uma consulta só e consulta uma vez só!”. Expliquei: "Quando fazemos qualquer compra, pagamos impostos ao governo, os quais devem ser revertidos para saúde, segurança, educação etc., porém vocês acham que esse dinheiro arrecadado é revertido para essas áreas? Caso fossem convertidos em serviços públicos, não precisaríamos pagar planos de saúde, escolas particulares, segurança privada, não acham?”. Assim, compreenderam que os impostos são a primeira forma de pagamento. A segunda é o pagamento do plano de saúde que sequer garante uma consulta quando o usuário precisa. A aluna (77) comenta: “Agora, se pagar uma consulta particular, ligeirinho eles atendem, arrumam horário, quarto, tudo". A aluna (72) se surpreende: “Que horror, professora, três vezes a gente paga e nem se dá conta”. (Diário de classe, 3 de outubro de 2012).

Neste excerto, observa-se um momento de intensa reflexão crítica sobre a temática da saúde pública e privada que vem enfrentando grandes problemas em nosso país, conforme noticiado pelo jornal. Essa é uma problemática de bastante interesse da turma, tendo em vista que a maioria dos educandos são idosos e vivenciam essas dificuldades cotidianamente. Daí a relevância de uma reflexão crítica sobre o assunto para uma tomada de consciência pelos educandos.

Nesse sentido, Freire e Macedo (2011, p. 184) afirmam que “[...] os educadores devem desenvolver estruturas pedagógicas radicais que propiciem aos educandos a oportunidade de utilizar sua própria realidade como base para alfabetização". Segundo os autores, essa postura 
permite aos sujeitos expressarem seus anseios, suas necessidades, medos e aspirações, e isso os instrumentaliza para a luta por melhorias sociais. Este é o processo de empoderamento, o qual deve possibilitar que os educandos se apropriem daqueles aspectos da cultura dominante que lhes oferecerão base para transformá-la. Esse empoderamento é percebido no momento em que os educandos examinam a situação da saúde em nosso país e, através da reflexão crítica, tomam consciência do quanto estão sendo oprimidos pelos sistemas de saúde, pelo Estado. Ao unir a leitura da palavra à leitura do mundo, o uso do jornal permitiu a reflexão crítica sobre os problemas cotidianos, a ampliação da compreensão do mundo e da realidade e ainda o empoderamento individual e social dos sujeitos envolvidos.

Para concluir, entendo que a promoção de atitudes críticas e conscientes junto a sujeitos da EJA não vai transformar sozinha o status quo dessas pessoas, contudo, no decorrer do projeto, percebi que os educandos já utilizavam de forma bem mais autônoma os processos de reflexão crítica. Esse é um ato político e pedagógico que conduz à cidadania.

\section{AMPLIANDO $\varepsilon$ FORTALECENDO PRÁTICAS DE LETRAMENTO}

Partindo do pressuposto de que todos possuem um grau de letramento e de que o resgate da cidadania, no caso dos grupos pouco escolarizados, passa necessariamente pela transformação de práticas sociais que os excluem, é que busco analisar como esse projeto de letramento com o jornal interfere e/ou contribui para ampliação das práticas sociais de leitura e escrita dos alfabetizandos da EJA. No decorrer do projeto, foi possível perceber o conhecimento dos educandos em relação à escrita, assim como também ficaram evidentes singelas mudanças de postura em relação à leitura do jornal.

Nesse sentido, concordo com Hara (1992, p. 27) ao afirmar que “[...] é surpreendente a variedade de informações que os adultos não 
alfabetizados podem tirar de um texto escrito". Suas reflexões vão ao encontro do que pude evidenciar na prática de leitura com o jornal:

Uma manchete de jornal pode ser lida mesmo que a
pessoa não decodifique todas as palavras; pelo contexto
e pelas palavras que consegue ler ela pode tirar o sig-
nificado. E esse é um momento importante porque do
significado ela pode ou não confirmar as palavras que
intuiu observando as letras. Ao ser estimulado pelo
desafio, muitas informações vão sendo mobilizadas e
não dizem respeito apenas ao gráfico, mas têm muito a
ver com o significado, com o captado nas relações com
o mundo. (Hara, 1992, p. 26).

Essas proposições podem ser observadas nas falas das educandas ao se reportarem às tentativas de leitura que realizam fora da escola, nas quais pude perceber pequenas mudanças de comportamento em relação ao uso do jornal para além da escola. Algumas delas me disseram que levavam o jornal para "ler" em casa e mostrar aos familiares o que aprenderam em aula. A aluna (77) disse que, quando o leva para casa, sua filha pergunta o que está escrito e, como ela já viu em aula, consegue ler algumas coisas. Assim, a filha fica feliz ao vê-la lendo, e, segundo ela, o hábito de ler em aula ajuda bastante. Da mesma maneira, a aluna (79) relata que, em casa, seus filhos compram o jornal durante toda semana. Então, de vez em quando, ela tenta ler ou reconhecer algumas letras, e os filhos ficam intrigados para saber o que ela está vendo, então ela responde: "Ué, tô lendo o jornal".

Os exemplos ilustram o encorajamento das alunas em relação à leitura do jornal. Em casa e com o incentivo dos familiares, elas demonstram interesse na busca de compreender as notícias do jornal, o que corrobora a sugestão de Kleiman (2012): os projetos de letramento devem se originar de um interesse real na vida dos educandos, envolvendo textos que circulam na sociedade. 
Assim, entendo que a leitura do jornal em aula se configura como um projeto de letramento, tal como definido pela autora, sendo uma tentativa de inserção social nas práticas letradas dos sujeitos pouco escolarizados. Contudo, a inserção do sujeito em uma nova prática social é um processo mais amplo, demorado, que não depende apenas das práticas escolares, pois deve ocorrer e ser promovido também em outros ambientes, como vimos nos exemplos dos familiares.

O importante é que esse tipo de atividade tem o potencial de subsidiar múltiplos letramentos em contextos escolares e não escolares, ao favorecer a apropriação da língua escrita inserida na leitura do mundo. Conforme já analisado neste artigo, a prática de letramento com o jornal empodera os sujeitos em processo de alfabetização e contribui com a inserção deles no mundo letrado, pois está intimamente articulada aos avanços na aquisição da língua e à leitura crítica de mundo.

O encorajamento ainda pode ser percebido na fala de uma aluna em um momento de avaliação deste projeto, no final do semestre:

Eu acho bom, né, professora, porque antes eu achava que só aquelas pessoas que sabiam ler bem correto é que compravam o jornal. Eu tinha vergonha antes, porque se alguém me perguntasse eu não ia saber dizer o que está escrito. [Aluna (72)]

Nesse sentido, concordo com Kleiman (2012) quando a autora afirma que o projeto mostrará aos educandos - sem que eles percebam que estão aprendendo - a gramática, a textualidade, os gêneros, enfim, elementos que os possibilitem agir por meio da leitura e da produção textual. Por fim, entendo que o projeto de letramento com o jornal buscou romper com processos de exclusão sustentados pelas funções da linguagem que distinguem os grupos sociais e seus produtos simbólicos. Nessa análise, o projeto apresentado foi capaz de produzir 
aproximações entre os alfabetizandos e o jornal, um dos símbolos da cultura letrada, fortalecendo-os e encorajando-os para uma inserção social mais plena no mundo da escrita.

\section{CONSIDERAÇÕES FINAIS}

Ao final deste trabalho, retomo a questão que persegui no decorrer da pesquisa: De que modo esse projeto de letramento com o uso do jornal contribui para a apropriação da língua escrita, para a reflexão crítica sobre o mundo e para a ampliação das práticas sociais de leitura e escrita dos educandos de uma turma de alfabetização de jovens e adultos?

Para a apropriação da língua escrita, o projeto contribuiu inserindo plenamente a alfabetização no processo de letramento. Para a reflexão crítica de mundo, o projeto ofertou momentos de construção coletiva de sentidos e significados, conduzindo os sujeitos à cidadania. Para a ampliação das práticas sociais de leitura e escrita, o projeto promoveu o letramento social a partir do letramento escolar.

Ainda é importante salientar as potencialidades do jornal e refletir sobre o seu papel e sua relevância no projeto. Assim, se houve avanços na aquisição da língua escrita, é porque a linguagem completa, funcional e contextualizada oferecida pelo jornal permitiu. Se houve momentos de reflexão crítica da realidade, isso foi possibilitado pelos aspectos do cotidiano e do mundo apresentados nas páginas do jornal. Se houve ampliação da inserção dos alunos nas práticas sociais de leitura e escrita para além da escola, é também porque o material oferecido é próprio destas práticas, é real e completo; não é uma cópia de um texto ou parte de uma reportagem desligada do seu portador original. Portanto, todas essas oportunidades, que auxiliam o processo de alfabetização, tornaram-se possíveis pelo uso do jornal.

Acredito que essa "imitação" da realidade, promovida por meio da leitura do jornal na escola, é um exercício de letramento que só tem 
a contribuir com o desenvolvimento de novas práticas sociais de uso da leitura e da escrita. Esta seria a compreensão de Tfouni (1995) em relação ao letramento enquanto um continuum. Apesar do processo de letramento ter início desde o nascimento de um sujeito, quando imerso em um meio letrado, esse alcança níveis mais complexos. Em suma, as práticas pedagógicas que aproximam a leitura do mundo e da palavra podem trazer muito mais contribuições para inserção dos sujeitos em suas demandas cotidianas.

De forma geral, considerando as três dimensões analisadas, elas indicam o potencial do projeto para o empoderamento dos sujeitos perante a sociedade, entendido como uma potencialização, tanto para atuar como cidadãos críticos como para participar das práticas sociais letradas.

\section{REFERENNCIAS}

BRAGGIO, S. L. B. Leitura e alfabetização: da concepção mecanicista à sociopsicolinguística. Porto Alegre: Artes Médicas, 1992.

FREIRE, P. A importância do ato de ler: em três artigos que se completam. 47. ed. São Paulo: Cortez, 2006.

Pedagogia da autonomia: saberes necessários à prática educativa. 25. ed. São Paulo: Paz e Terra, 1996. Disponível em: <http://forumeja.org.br/ files/Autonomia.pdf>. Acesso em: 20 jun. 2013.

FREIRE, P.; MACEDO, D. Alfabetização: leitura da palavra, leitura do mundo. Rio de Janeiro: Paz e Terra, 2011.

GIROUX, H. A. Introdução: alfabetização e a pedagogia do empowerment político. In: FREIRE, P.; MACEDO, D. Alfabetização: leitura da palavra, leitura do mundo. Rio de Janeiro: Paz e Terra, 2011. p. 33-77.

HARA, R. Alfabetização de adultos: ainda um dasafio. 3. ed. São Paulo: CEDI, 1992. 
KLEIMAN, A. B. EJA e o ensino da língua materna: relevância dos projetos de letramento. Florianópolis: IFSC, 2012. Vol. 1. Disponível em: <http:// incubadora.periodicos.ifsc.edu.br/index.php/EJA/article/view/>. Acesso em: 29 abr. 2013.

. O processo de aculturação pela escrita: ensino da forma ou aprendizagem da função? In: KLEIMAN, A. B.; SIGNORINI, I. (Org.). O ensino e a formação do professor: alfabetização de jovens e adultos. Porto Alegre: Artmed, 2000, p. 223-243.

KLEIMAN, A. B. (Org.). Os significados do letramento: uma nova perspectiva sobre a prática social da escrita. 2. ed. Campinas: Mercado das Letras, 2007. MARINHO, M. Pequenas histórias sobre este livro e sobre o termo letramento. In: . (Org.). Cultura escrita e letramento. Belo Horizonte: Editora UFMG, 2010.

OLIVEIRA, M. K. Jovens e adultos como sujeitos de conhecimento e aprendizagem. In: FÁVERO, O.; IRELAND, T. D. (Org.). Educação como exercício de diversidade. Brasília: MEC, UNESCO, ANPed, 2007, p. 61-84.

. Letramento e transformações cognitivas. Reunião da ANPED/16, Caxambu, MG, 12 a 17 set. 1993. (Texto digitado.)

SOARES, M. Letramento e escolarização. In: RIBEIRO, V. M. (Org.). Letramento no Brasil: reflexões a partir do INAF 2001. São Paulo: Global, 2003. p. 89-113.

. Práticas de letramento e implicações para a pesquisa e para políticas de alfabetização e letramento. In: MARINHO, M.; CARVALHO, G. T. (Org.). Cultura escrita e letramento. Belo Horizonte, MG: Editora UFMG, 2010. p. 54-67.

STREET, B. V. Os novos estudos sobre o letramento: histórico e perspectivas. In: MARINHO, M.; CARVALHO, G. T. (Org.). Cultura escrita e letramento. Belo Horizonte: Editora UFMG, 2010. p. 33-53.

TFOUNI, L. V. A escrita - remédio ou veneno? In: PRADO, E.; AZEVEDO, M.; MARQUES, M. (Org.). Alfabetização hoje. São Paulo: Cortez, 1995. 


\section{"Caprichem nas folhinhas": infantilização das práticas pedagógicas \\ $e$ docência na EJA \\ Márjori Bez Reus}

\section{AS PRIMEIRAS PALAVRAS}

Abordar a temática da infantilização das práticas pedagógicas na Educação de Jovens e Adultos (EJA), problematizando teórica e reflexivamente os processos que motivam ou justificam tais práticas, deu-se em razão da trajetória docente percorrida durante o período do Estágio Curricular Obrigatório, que vivenciamos ${ }^{1}$ na sétima etapa do curso de Pedagogia na Universidade Federal do Rio Grande do Sul. Para a escolha do tema que seria o eixo a ser desenvolvido durante o período do estágio, pensamos em muitas possibilidades. Buscamos conhecer a realidade social e as expectativas dos estudantes que seriam os protagonistas desse planejamento.

As práticas realizadas pela professora titular da turma, vinculadas à leitura e à escrita, as quais despertaram o interesse dos educandos,

\footnotetext{
${ }^{1}$ Fazemos uso da primeira pessoa do plural na escrita desse artigo, por compreendermos que mesmo tratando-se de um estudo de caso, a problemática abordada refere-se a uma realidade presente em vários outros espaços, envolvendo vários outros agentes.
} 
acabaram por influenciar para que decidíssemos abordar o letramento como tema central na nossa prática docente. $\mathrm{O}$ objetivo foi, a partir do pensamento de Tfouni (2001), compreender o letramento como "[...] fenômeno sócio-histórico", considerando que "[...] investigá-lo implica estudar as transformações que ocorrem em uma sociedade quando suas atividades passam a ser permeadas por um sistema de escrita cujo uso é generalizado" (p. 55).

Nesse caso, fazer uso adequado do conceito de letramento estaria ligado a práticas relacionadas a ele. Para tal, seria necessário utilizar textos que estivessem presentes no cotidiano dos estudantes, de modo a propiciar, assim, uma aprendizagem útil para a vida deles, pois, como salienta Tfouni (2001, p. 57), “[...] as pessoas aprendem a ler informações que são necessárias para a organização de suas atividades”.

Partindo do que foi acima referido, percebemos hoje, com o distanciamento que o tempo permitiu, que a falta de entendimento da amplitude do conceito e das maneiras de colocá-lo em prática em sala de aula fizeram com que, na complexidade do ato de planejar, nós nos desviássemos de nossas concepções e princípios, do que entendemos como importante para a educação. Esse olhar crítico para práticas infantilizadoras em turmas de EJA foi motivado pelos estudos realizados durante a graduação. Com diálogos em sala de aula e leituras percebemos que, para abordar os conteúdos em uma sala de EJA, não era possível somente "adequar" as atividades propostas para crianças, adaptando-as aos jovens e adultos, uma vez que a proposta da EJA, como modalidade de ensino, não é simplesmente uma adaptação das práticas escolares com crianças e adolescentes. Era necessário rever a funcionalidade da aprendizagem de determinados conteúdos em detrimento de outros, passando a enxergar os educandos como membros ativos no seu processo de aprendizagem e elencar saberes que influenciassem no seu cotidiano, auxiliando-os em sua vida. 
No papel de aprendiz docente, fomos para a sala de aula certas de que faríamos uma boa prática, por estarmos convictas de que tínhamos bons fundamentos teóricos para eleger quais seriam as melhores propostas para aquele público. Havia grandes possibilidades de desenvolver um trabalho com viés progressista em relação ao letramento, mas era necessário que, ao planejar, compreendêssemos a relevância do uso social da escrita para os jovens e adultos, como salienta o documento da VI Conferência Internacional de Educação de Adultos (Confintea), de 2010, quando ressalta, na página 8 , que é importante

[...] desenvolver uma oferta de alfabetização rele-
vante e adaptada às necessidades dos educandos e que
conduza à obtenção de conhecimentos, capacidades e
competências funcionais e sustentáveis, [...] para que
continuem a aprender ao longo da vida [...].

Era necessário, portanto, rever o posicionamento que, mesmo de maneira aparentemente desproposital, foi adotado no planejamento e em nossa postura docente. Era importante perceber que "[...] a principal preocupação do trabalho pedagógico bem como dos processos de avaliação não deve ser o saber enciclopédico" (Oliveira, 2008, p. 28). Assim, o docente não deve se preocupar unicamente em "cumprir com os conteúdos" e fazer com que os estudantes aprendam. O esforço precisa ser concentrado primeiramente no questionamento a respeito de quais conteúdos realmente são importantes para a vida dos estudantes da EJA.

Faremos o aprofundamento do estudo a partir de alguns pressupostos pertinentes para essas reflexões. Um deles, o nosso próprio processo de escolarização, que foi calcado em uma visão de desconsideração do educando, sendo este visto como um sujeito que está presente apenas para receber o conhecimento. Esse pode ser considerado um dos fatores de maior influência para as escolhas feitas. A retomada da trajetória discente de uma maneira reflexiva, observando-a agora com a sensibilidade do olhar docente, é importante para a construção 
do objeto de estudo, à medida que auxilia na compreensão de nosso “desvio pedagógico". Isso porque a cultura escolar está arraigada no nosso entendimento do que seja a escola e as práticas que a constituem. O entendimento crítico da existência dessa cultura escolar conteudista faz compreender porque, no momento do retorno para esse mesmo ambiente, retomamos as práticas vividas na infância, como forma de validar o espaço escolar.

Por essas considerações, nosso interesse é compreender o quanto essas práticas estão presentes dentro das escolas com estudantes da EJA, nos anos iniciais, e o que motiva ou justifica a manutenção delas pelos docentes.

\section{PALAVRAS QUE CONTRIBUÍRAM PARA NOVAS REFLEXÕES}

Para aprofundar o estudo a respeito das práticas docentes infantilizadoras na EJA, fazem-se necessárias reflexões sobre alguns conceitos que enriquecem a discussão a respeito do tema abordado. Os conceitos serão explorados conjuntamente a fim de promover uma visão integrada da pesquisa desenvolvida. Cumpre destacar que, logo que nos interessamos pela temática da infantilização que ocorre no exercício da docência junto aos estudantes da EJA, pouco encontramos que se refere especificamente ao tema, apenas trabalhos que tangenciavam o estudo, trazendo, portanto, o currículo da EJA como foco - não especificamente a infantilização.

Grandes são os desafios no exercício da docência na educação de jovens e adultos. Afirmamos isso, pois, durante o período de Estágio Curricular Obrigatório, algumas dificuldades puderam ser sentidas e materializadas, através da observação minuciosa e de um olhar que foi provocado constantemente pela orientadora. Uma das dificuldades mais evidentes foi o processo avaliativo. Compreender as especificidades do aluno no momento da avaliação é fundamental. Já há algum 
tempo vem sendo debatida a questão: avaliar o aluno como parâmetro de si mesmo, analisando seu percurso, as evoluções realizadas por ele durante o período avaliativo. O que espantosamente ocorre em algumas turmas de EJA é a generalização dos alunos apontados com dificuldade de aprendizagem.

Nesses casos, devemos lançar um olhar de estranhamento frente a essas afirmações e questionar: em relação a que esses alunos possuem dificuldade? É importante pensar que esses mesmos sujeitos desempenham muitas tarefas que requerem a utilização do raciocínio com grande habilidade, em diversos momentos. Considerar esses fatores é ter a “[...] consciência de que estes homens e mulheres não são tábulas rasas, mas portam um sem-número de experiências sociais, culturais, afetivas que lhes permitem o acúmulo de saberes em diferentes campos epistemológicos" (Moll, 2004, p. 14).

Assim, as expectativas dos professores quanto à aprendizagem dos estudantes jovens e adultos e a compreensão do processo de aprendizagem e avaliação são fatores que se encontram, em muitos casos, distanciados de uma concepção que objetiva que estes sujeitos sejam participativos no processo de aprender. Educadores e educadoras também necessitam de um olhar diferenciado à medida que atuam com um público, por sua vez, diverso. Torna-se fundamental a "[...] postura para uma sensível escuta cotidiana como também para uma ampliação do olhar" (Moll, 2004, p. 14).

Faz-se necessário colocar em voga a discussão da infantilização do espaço, das atividades, das atitudes e posturas docentes junto aos alunos da EJA. Essas ações emergem de um pensamento que compreende os sujeitos pouco escolarizados como pessoas inferiores, incompletas, mesmo na perversidade de um discurso aparentemente acolhedor que os rotula como "excluídos”. Álvaro Vieira Pinto (2010, p. 90) considera que a “[...] concepção ingênua do processo de educação de adultos deriva do 
que se pode chamar de uma 'visão regressiva': considera o adulto analfabeto como uma criança que cessou de desenvolver-se culturalmente".

Essa visão precisa, conforme o pensamento desse autor, ser superada pelos docentes, pois ela traz consigo a desconsideração das aprendizagens anteriores dos sujeitos. O que se promove, nesses moldes, é uma "educação opressora", "bancária", como afirma Paulo Freire (1987). O aluno é concebido como sujeito passivo no processo de ensino e aprendizagem, e o professor, por sua vez, transmite conteúdos escolares desconectados da realidade, deixando de agregar novos sentidos para os estudantes.

Durante o processo de formação, o docente deve ter acesso a informações, textos e discussões que o façam compreender o quanto a abordagem pedagógica na EJA se faz necessariamente diferenciada. Além disso, o contato com materiais apropriados para a realização de um bom trabalho com o público que compõe a EJA é fundamental, bem como o vínculo que os conteúdos devem possuir com a vida cotidiana dos estudantes.

Também pretendemos problematizar a formação de professores, ou seja, buscar compreender nossa tarefa docente com o objetivo de possibilitar ao sujeito que aprende subsídios para que ele perceba a perversidade da opressão e da discriminação na sociedade em que está inserido e, a partir dessa percepção, partindo dos seus saberes, realize discussões acerca da sua condição social e de alternativas de mudança.

\section{METODOLOGIA: OS PASSOS PARA A PESQUISA}

A infantilização das práticas pedagógicas na educação de jovens e adultos foi o tema central dessa pesquisa, e, portanto, foi dele que emergiram os subtemas e tensionamentos que geraram as reflexões acerca da referida problemática. A fim de potencializar sua análise, julgamos necessário sair a campo e retornar à escola na qual realizamos o estágio, pois, durante o período de observação, que antecedeu o momento de prática, constatamos que a professora titular da turma 
também realizava práticas infantilizadoras. Sendo assim, esse poderia ser um espaço de reflexão importante e profícuo no que diz respeito à riqueza das análises e à possibilidade de contribuir com o trabalho da professora. Para o retorno, planejamos dialogar com essa profissional e fazer alguns questionamentos a respeito das propostas que ela traria para a turma, para verificar sob quais bases epistemológicas ela alicerça o planejamento das aulas e, a partir dessas conversas, buscar elementos para compreender os motivos que a levam a propor os conteúdos de maneira infantilizada para os alunos.

Tratando-se, portanto, de um estudo que se efetiva no campo da educação, a escolha metodológica foi a realização de uma pesquisa de cunho qualitativo, do tipo estudo de caso. A escolha pelo aprofundamento dos estudos direcionados à prática da professora se deu em razão do interesse em compreender como uma profissional que está em um momento relativamente inicial de sua carreira realiza práticas infantilizadoras com um olhar de pouca criticidade para a própria docência. Quanto ao interesse pela singularidade que percebemos no estudo de caso, Lüdke e André (1986, p. 17) salientam que

O estudo de caso é o estudo de um caso [...] o caso pode ser similar a outros, mas é ao mesmo tempo distinto, pois tem um interesse próprio, singular [...] o interesse, portanto, incide naquilo que ele tem de único, de particular, mesmo que posteriormente venham a ficar evidentes certas semelhanças com outros casos ou situações.

As preocupações metodológicas que tangenciam essa pesquisa, desde o seu início, aproximam-se das características que Godoy (1995, p. 62) elenca como essenciais para afirmar o que define uma pesquisa qualitativa:

Os estudos denominados qualitativos têm como preocupação fundamental o estudo e a análise do mundo 
empírico em seu ambiente natural. Nessa abordagem valoriza-se o contato direto e prolongado do pesquisador com o ambiente e a situação que está sendo estudada.

A nossa permanência na sala de aula, através da observação participante, vivenciando as práticas docentes da professora, tornou-se fundamental, como o referido por Godoy (1995), pois permitiu a observação de pontos importantíssimos para o desenvolvimento do tema central que em apenas uma entrevista com a professora poderiam ser negligenciados, tais como: a reação dos alunos em diferentes momentos, o clima da sala de aula, as circunstâncias nas quais as propostas foram realizadas.

Embora já estivesse familiarizada com o ambiente de pesquisa, retornamos com outro olhar, buscando novas perspectivas e procurando manter o distanciamento necessário que permitisse uma observação crítica. A riqueza com que a observação participante, como procedimento investigativo, contribui para a pesquisa é ressaltada por Gaskell (2002, p. 72):

Na observação participante, o pesquisador está aberto a uma maior amplitude e profundidade de informação, é capaz de triangular diferentes impressões e observações e consegue conferir discrepâncias emergentes do decurso do trabalho de campo.

A realização de estudo de caso que problematizou a prática da professora regente da turma, que nesses escritos será chamada de "Mistério", ${ }^{2}$ proporcionou elementos fundamentais para que pudéssemos alcançar os objetivos traçados. O tema esteve intimamente relacionado à formação de professores, uma vez que buscou compreender como os estudos e as constantes formações têm contribuído para a

${ }^{2}$ Para preservar a identidade da professora e do estudante que serão citados neste trabalho utilizamos pseudônimos que estão relacionados aos sentimentos que se tornaram mais evidentes durante o processo de pesquisa. 
mudança de suas práticas pedagógicas, visto que preservam uma cultura escolar tradicional, arraigada em conceitos que podem ter se consolidado ainda no período em que eram estudantes. Instigou-nos a buscar compreender o que leva alguns professores a adotar, em sua prática, recursos didáticos que desvalorizam os conhecimentos dos alunos e propõem o conhecimento como algo pronto, mesmo que sejam profissionais que se mantêm em constante formação.

Ao conviver com a turma e tendo contato com o trabalho da professora, percebemos que se trata de uma docente comprometida com seu trabalho e empenhada em realizar uma prática que contribua positivamente para a vida dos alunos. Dessa forma, a inadequação de sua prática adquire certa invisibilidade quanto à infantilização dos recursos disponibilizados aos alunos, assim como a maneira como os trata. Nesse aspecto nos aproximamos do que é vivido por esta professora, uma vez que essa impossibilidade de perceber esses equívocos também ocorreram conosco. Para tanto, ter a oportunidade de problematizar a prática docente da professora Mistério é como ter a possibilidade de compreender o que causa essa invisibilidade para nós e para outros colegas de profissão. Nesse ponto, é possível compreender que há a possibilidade de que este estudo não seja restrito apenas ao caso estudado.

Para estruturar a pesquisa e organizar nosso olhar frente ao espaço observado, criamos tópicos-guias que visaram a uma ampliação do olhar diante da realidade observada. Foram eles: inadequação dos materiais, falta de aprofundamento das temáticas abordadas na sala de aula e postura docente infantilizadora no que se refere ao tratamento destinado aos estudantes. Buscamos, através de cada um deles, compreender os motivos que levam a práticas infantilizadoras - ou que as justificam na Educação de Jovens e Adultos. Tal categorização foi necessária como forma de organizar nossos escritos e torná-los acessíveis aos leitores, mas de fato essas categorias estão intimamente ligadas, compondo uma rede. 
Observar quais eram os materiais disponibilizados aos alunos, a maneira como eles receberam as atividades e quais foram as dificuldades para realizá-las, qual a motivação - ou se houve falta dela durante a execução dos exercícios foi fundamental para compreender quais são as repercussões de práticas infantilizadoras com estudantes jovens e adultos. Observar o posicionamento da professora durante as conversas que tivemos, buscando conhecer se havia a subestimação da capacidade dos alunos, auxiliou no entendimento da infantilização das atividades. Foi importante perceber se a professora enxergava seus alunos pela ótica da ausência ou das potencialidades, tendo por princípio que este olhar docente é um grande influenciador nos momentos de planejamento.

O último tópico tratado foi o que se relaciona com a postura docente infantilizadora. Esse foi um dos fatores que permitiu a ampliação de nosso olhar frente à pesquisa realizada. Buscamos analisar, na fala e nos gestos da professora, sinais de infantilização com a turma, a fim de perceber se ela os colocava em uma situação semelhante ao que se tem feito com as crianças.

As escolhas sobre o percurso que foi traçado para a pesquisa ocorreram previamente e visando aos objetivos desta pesquisa, tendo por princípio o que salienta Duarte (2002, p. 141),

A definição de critérios segundo os quais serão selecionados os sujeitos que vão compor o universo de investigação é algo primordial, pois interfere diretamente na qualidade das informações a partir das quais será possível construir a análise e chegar à compreensão mais ampla do problema delineado.

Após a conclusão do trabalho de campo, os questionamentos a respeito das análises possíveis, no sentido de realizar uma leitura em profundidade do material de que dispusemos, também foi um grande 
desafio. Foram grandes os esforços empenhados para que a ida a campo realmente ocorresse como esperado. ${ }^{3}$

É muito gratificante perceber que o estudo desenvolvido poderá contribuir para o campo da educação e, mais especificamente, para o campo da Educação de Jovens e Adultos (EJA), no que diz respeito aos tensionamentos que propusemos e às propostas que pretendemos compartilhar com a professora Mistério e com outros profissionais da Educação.

\section{A INFANTILIZAÇÃO: A INVISIBILIDADE OU A IMPOSSIBILIDADE}

A provocação que buscamos realizar nesse título esteve presente durante toda a pesquisa e envolve compreender porque a infantilização se torna invisível para alguns docentes, enquanto, para outros, essa inadequação torna-se uma grande inquietação. Nessa nova oportunidade, quando retornamos ao mesmo lugar, podendo vivenciar o espaço com outro olhar, ficamos perplexas por perceber que a infantilização também estava invisível aos nossos olhos de uma maneira tal que, quando fomos postas a pensar sobre o tema, instigadas pela professora orientadora do estágio, ficamos impressionadas!

Mas a grande pergunta é: por que há essa impossibilidade de percebermos sozinhos? Pudemos compreender que uma das possíveis explicações para tais procedimentos está na cultura escolar conteudista, ou seja, na reprodução de um modo padronizado de propor as atividades, de valorizar os mesmos conteúdos repetidos a cada ano, como se fossem prontos e acabados. Referimos o termo adequação por entendermos que, ao propormos aos jovens e adultos da EJA as mesmas atividades que dispomos às crianças em fase de alfabetização, fazemos adequações que pouco contribuem para seus processos de emancipação.

\footnotetext{
${ }^{3}$ Cabe salientar que são vários os trâmites necessários para a realização de observação em escolas da rede municipal de Porto Alegre, bem como o fato de não estarmos isentos de outros impeditivos para que o trabalho de campo seja realizado como se espera.
} 
Sobre essa temática, consideramos relevante o que salientam Di Pierro, Joia e Ribeiro (2001, p. 70):

[...] os objetivos da formação de pessoas jovens e adultas não se restringem à compensação da educação básica não adquirida no passado, mas visam a responder às múltiplas necessidades formativas que os indivíduos têm no presente e terão no futuro.

Para tanto, é necessário compreender o currículo da EJA, de modo que os professores possam considerar que "a lista de conteúdos" precisa ser revista e, até mesmo, superada.

É notória a dificuldade que os educandos apresentaram de fazer conexões do que aprendem em sala de aula com o que vivem durante o dia em seus afazeres. Isso se evidencia em falas como a do estudante Cansaço:

"Tem coisas que a gente nem usa, mas aqui na escola a gente tem que aprender”. (fala do estudante durante uma aula observada).

\section{A inadequação das atividades: a atividade a serviço do conteúdo ou o conteúdo a serviço da atividade?}

Durante a busca de referências que auxiliassem nos estudos a respeito da infantilização dos materiais disponibilizados aos jovens e adultos da EJA, surpreendemo-nos ao verificar que a infantilização, objeto de estudo nesse trabalho, já ocorre há muito tempo, conforme salienta Fávero (s.d., p. 6) quando relata os exercícios de uma cartilha que circulava no país e servia como recurso fundamental para a alfabetização dos jovens e adultos.

A lição que introduz o $x$ é especialmente divertida. A figura apresenta um peixe com um xale tomando uma xícara de chá. É um bom exemplo da infantilização do 
material oferecido aos adultos. Utilizar este material para alfabetizar jovens e adultos do meio rural é, no mínimo, ridículo. Esse livro era fartamente distribuído em todo o Brasil.

A constatação de que textos da década de 1950 tenham muitas semelhanças aos encontrados ainda hoje nas turmas de EJA é preocupante. Já naquele momento histórico esses materiais eram motivo de críticas pelos estudiosos que percebiam o quanto as cartilhas abordavam de maneira errônea os conteúdos para os estudantes adultos e desconsideravam a importância dos conhecimentos prévios de cada sujeito.

Referindo-nos especificamente à prática da professora Mistério, o entendimento da alfabetização como apenas a aquisição da leitura e da escrita desconsidera o contexto e a importância social que o período da alfabetização como etapa da escolarização possui. Algumas das escolhas da professora Mistério para a elaboração de suas atividades estão vinculadas à concepção de alfabetização que ela possui. Isso se torna evidente quando analisamos a maneira como ela propôs a aprendizagem das letras do alfabeto, utilizando materiais que valorizam a existência de uma letra em específico, mas que, por vezes, não possuem sentido algum.

Uma atividade que de fato surpreendeu por sua complexidade foi a proposta de leitura do texto "Bicho Raro e Estranho" (Figura 1), uma vez que exigiu a retomada da leitura pelos estudantes e a intervenção da professora Mistério para explicar o sentido do texto a eles, visto que todos estão em período de alfabetização. Além de ser um tema de cunho infantil, não houve o aprofundamento da temática proposta no texto. Logo, a conversa voltou-se para a análise da pontuação utilizada pelo autor. Houve a exploração do uso do travessão e das vírgulas, após esse momento, a professora pediu que os estudantes individualmente relessem a história e adicionassem novos personagens com novas falas. Neste momento nos perguntamos: o que essa atividade de ampliação 
dos diálogos dos personagens do texto contribuirá de fato para a ampliação das aprendizagens dos educandos? Qual é a finalidade dessa proposta?

\section{BICHO RARO E ESTRANHO}

Foi o cachorro que cliegou correndo crias a língaa de fora e conton para o jayali:

- Descobri unl Bsta cscondido em cima de uma pedra, lá cmbaixo.

E for a coruja que ouvin o papo e perguncou:

- Voce tem certena? Olhe que nem semyre as lendas slio verdadeiras.

Fissocou naquele momento o decidiu:

- B melhor verifien. Afinal, algum deve meano cer aobrado.

I foi assim que os animais descenm a montan ha pana comprovara hisorón do cachorro.

- Gozado, me dell vontade de levar uma maçă pra qualquer emergencia.

Tis caresto passarinho falou:

- I ca estou que nä́o aglierito de medo de lovar uma pedrada.
No fim, o jacaré comontous

- Acho que vou chorar.

Cheganam.

O macaco cogon a barrija e comcntou:

- E verdade, Sobrou só um. Mesmo assim node ser perigoso, Quase acabou com minta familia. E olha que somos primos $\mathrm{cm}$ terceiro graz.

17. A ooca lambeu os beiços e acrescentots:

in - Fo sinico que mata sem ter fous.

A borbsleta ubriu as asas c concluiu:

- Mas o que fuzemos com cle?

Thios os bichou ficaram cm silencio olhundo o homern, upavorado, ollatando rumbem paru eles. Fim todas as cabccas passivam as lembrangas de bichos o plantas destruidos. S6 que não sabiam mesmo o que fazer com aquelo homem ali, sobrevivente como eles. Bsperangoso e assustado como cles. Hicho gomo oles.

a E foi o cúsudo que, chegando arrasado no local, resolveu a questlos

Arho gue com o tero täo bonitinho como esse nilo merece acabar. Vamos deixa-lo vivo.

Acho que com o tempo cle aruende com a gente uma maneira melhor de yiver.

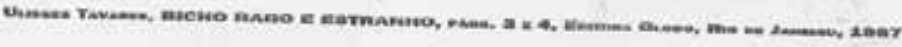

Figura 1 - Texto entregue aos estudantes pela professora Mistério

Essas perguntas fazem pensar sobre o que destaca Lopes (2008, p. 106):

O aluno espera que a educação escolar interaja com sua realidade de trabalho e de vida e que os conhecimentos construídos na escola sirvam de instrumentos de resolução de problemas, principalmente aqueles que impossibilitam encontrar meios de subsistência. 
Frente a esses argumentos, é preciso pensar: por que não abordar a pontuação de outra maneira? É possível perceber que esse tipo de texto pode colocar os educandos em uma posição constrangedora, a qual prevê uma leitura com dificuldades e a realização de atividades de escrita partindo de um referencial infantil? Buscamos dialogar com a professora sobre essas inquietações, e ela, por sua vez, salientou que desse jeito eles aprendem a utilizar de maneira adequada o travessão, como se houvesse obviedade nessa constatação.

É notório que, ao planejar, a professora Mistério coloca os temas a serviço do conteúdo, cristalizado nas atividades. Sendo assim, elenca qual atividade será realizada em aula e, de acordo com o que a atividade propõe, sugere temas a discutir. $\mathrm{O}$ mais apropriado é pensar na relação inversa: buscar temas a serem abordados, significativos para os estudantes e, após essa decisão, planejar a maneira pedagógica e os recursos que serão utilizados de forma a potencializar a aprendizagem, além, é claro, de considerar prioritariamente a qual público se destina essa intervenção, uma vez que

Refletir sobre como esses jovens e adultos pensam e aprendem envolve, portanto, transitar pelo menos por três campos que contribuem para a definição de seu lugar social: a condição de "não-crianças", a condição de excluídos da escola e a condição de membros de determinados grupos sociais. (Oliveira, 1999, p. 16).

É evidente que a professora Mistério desconsiderou estes campos apontados por Oliveira (1999) e não percebeu o quanto isso tornou-se visível através da dificuldade que os educandos demonstraram em compreender o sentido das atividades.

Assinalamos a invisibilidade da postura adotada pela professora Mistério, pois, quando propusemos à turma a leitura de textos com o mesmo teor infantil ("A barriga de H. Linha” de Sylvia Orthof, por exemplo), não pensávamos que esta "simples atividade", com o objetivo 
de verificação da capacidade que os estudantes possuíam de formar frases, traria consigo toda uma visão infantil dos jovens e adultos, indo de encontro à sua trajetória de vida e ao legado histórico da EJA.

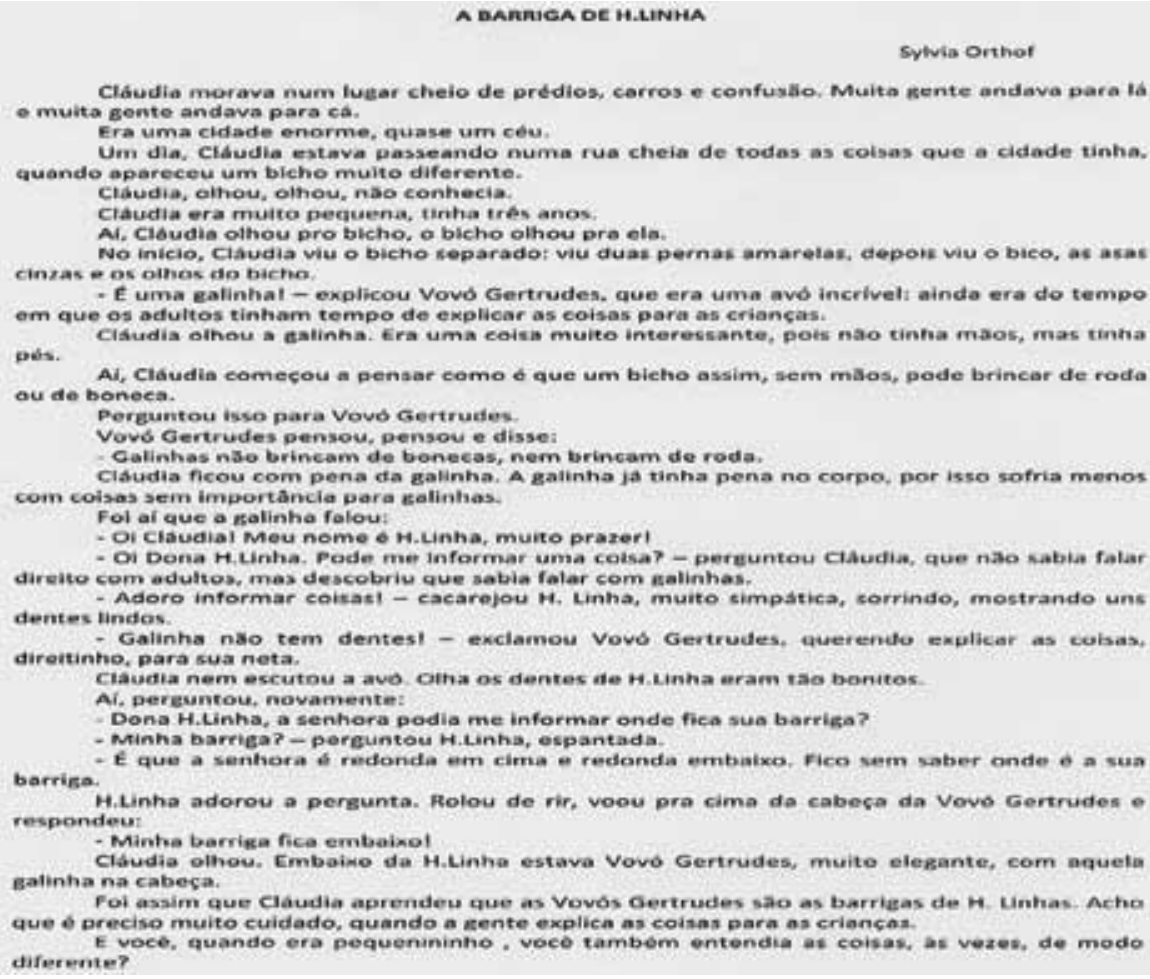

Figura 2 - Texto "A barriga de H. Linha" de Sylvia Orthof, entregue pela autora desse artigo em uma das aulas do Estágio Curricular Obrigatório em turma de EJA

Como se pode observar, seguimos a mesma lógica de planejamento que a professora Mistério, trazendo atividades de cunho infantilizado e puramente vinculadas a um conteúdo escolar tradicional. Notamos, nesse momento, a mesma dificuldade para a realização da atividade percebida na turma observada. Os estudantes, naquele episódio, demoraram muito tempo para formar as frases propostas através da distribuição de figuras que estavam relacionadas a um texto desconectado de suas realidades. 
Ao longo da conversa com a professora orientadora do estágio, após ela presenciar a proposta dessa atividade à turma, é que o olhar frente às atividades realmente foi mudando. Esse foi certamente um processo bastante dolorido, visto que romper com uma lógica de planejamento que estava de certa forma estruturada e rever o eixo que propunha as temáticas e a maneira de abordá-las foi um trabalho árduo. Hoje avaliamos que foi altamente positivo, já que, além de propiciar a discussão que ampliamos nesse trabalho, provocou uma mudança de concepção quanto à educação de jovens e adultos que afetou o nosso fazer docente.

\section{A formação docente, a infantilização \\ $e$ a $\varepsilon J A:$ no que se relacionam?}

Confundindo amorosidade com o "ser boazinha", um dos elementos que culmina em uma prática infantilizadora, por parte da professora Mistério, e no não questionamento dos estudantes sobre tais procedimentos, é a maneira como ela se relaciona com eles. Há, surpreendentemente, uma reciprocidade dos estudantes em relação a esse tratamento infantilizado que a professora manifesta em seu fazer. Talvez isto ocorra pelo fato de vivenciarem, agora, uma relação positiva com ela e, portanto, diferenciada em comparação com a vivida na escolarização na infância, que foi marcada pelo fracasso e, possivelmente, por lembranças negativas dos professores. Lopes (2008, p. 105), ao tratar desse tema destaca que:

[...] as razões que fazem, ainda hoje, alunos da EJA identificarem a professora como uma amiga, mãe e até psicóloga estão intrinsecamente relacionadas à compreensão distorcida, historicamente difundida, da profissionalização no magistério.

"Ser boazinha", nesse caso, remete a um modelo de professora que está sempre protegendo seus educandos como se eles fossem frágeis e 
necessitados; além disso, em vários momentos, há uma afirmação do seu "condicionamento de ser vocacionado" para o exercício da função (Lopes, 2008). Isso é diferente de uma relação entre professor e alunos pautada pela "amorosidade". Cleoni Fernandes (2008, p. 38) explica esse conceito com base na obra de Paulo Freire:

Amorosidade na visão freireana é vida, vida com pessoas, é qualidade que se torna substanciada ao longo de sua obra e de sua vida. Condição assentada na centralidade da possibilidade dialógica, que exige o amor e a confiança, em que o diálogo nunca está aprontado, é sempre um caminho.

De acordo com as palavras da autora, podemos considerar que a professora Mistério desconhece essa importante diferença. A partir disso, questionamos: qual será o motivo que leva o docente a agir dessa maneira, para além de um suposto sentimento maternal? Podemos encontrar algumas alternativas, ao pensar sobre sua trajetória de formação, uma vez que a professora Mistério, embora seja nomeada pela Prefeitura Municipal de Porto Alegre como professora da EJA, nunca participou, conforme seu relato, de propostas de formação continuada que se dedicassem aos estudos sobre a educação de jovens e adultos. Também relatou que, na universidade na qual realizou sua graduação, foram ausentes disciplinas destinadas à temática. Docente há mais de dez anos em turmas de EJA, Mistério aponta para uma grande lacuna formativa. Verificam-se, portanto, uma ausência de discussão das especificidades pedagógicas da EJA e o desconhecimento das lutas políticas vivenciadas para a implementação desta modalidade e da Educação Popular.

Ao analisar essa realidade formativa da professora, também pensamos sobre nossa formação. Mesmo com espaços para a discussão de dúvidas e incertezas, vivenciamos sérias dificuldades no momento do estágio docente para compreender tais questões, trazendo materiais 
destinados às crianças e reafirmando, em nossa prática, uma lógica da escolarização infantil. Sendo assim, podemos perceber como essas questões se potencializam no cotidiano da professora Mistério, que não teve as mesmas oportunidades de, coletivamente, realizar uma crítica ao seu trabalho, aprimorando-o.

Outro ponto relevante a destacar é a pouca abordagem dos temas referentes à educação de jovens e adultos nos cursos de licenciatura. Ainda são recorrentes falas como "adaptem aos jovens e adultos" conteúdos e materiais que são visivelmente destinados às crianças. Porém como adaptar materiais que contêm abelhinhas, sapinhos e personagens de desenhos infantis, além das histórias, todas com enredos fantasiosos e infantis, para estudantes jovens e adultos trabalhadores? A necessidade de distinção destes públicos em seus processos de escolarização evidencia-se nas palavras de Lopes (2008, p. 104): "Diante dessa especificidade, vai tornando-se cada vez mais claro que escolarizar jovens e adultos trabalhadores, independentemente da etapa em que esteja atuando o professor, não é reproduzir ou adaptar o ensino de crianças para adultos."

É evidente que, ao planejar, recorreremos ao nosso acervo didático, e se este não possuir materiais adequados, ou seja, pensados para a EJA (não meras adaptações), utilizaremos os materiais dos quais dispomos e faremos, assim, uma prática infantilizadora, que apenas reproduzirá a cultura escolar vigente. Como pessoas escolarizadas e docentes, facilmente recorreremos ao nosso processo de escolarização como base para desenvolver o nosso trabalho docente, mesmo questionando-o. A força dessa cultura está nas palavras de Julia (2001, p. 9):

A cultura escolar é descrita como um conjunto de normas que definem conhecimentos a ensinar e condutas a inculcar, e um conjunto de práticas que permitem a transmissão desses conhecimentos e a incorporação desses comportamentos. 
A cultura escolar conteudista está para além da memória do processo de escolarização do docente, ela se encontra presente nas escolas, instituindo regras e cristalizando ações, por vezes, pouco refletidas. Essa hipótese inicial da pesquisa corroborou-se a partir do momento em que presenciamos, durante as aulas ministradas pela professora Mistério, a realização de atividades que vivemos durante as séries iniciais do Ensino Fundamental. Além disso, nas palavras de Fávero (s.d), podemos perceber uma recorrência de processos infantilizadores há mais de sessenta anos.

Em razão disso, torna-se fundamental a discussão das práticas pedagógicas destinadas especificamente à EJA nos centros acadêmicos, de maneira que possibilitem, efetivamente, aos futuros docentes os subsídios necessários para a docência com jovens e adultos.

\section{CONSIDERAÇÕES FINAIS: INQUIETAÇÕES $\varepsilon$ DESCOBERTAS DO ESTUDO}

Esse estudo foi motivado a partir de um incômodo que sentimos no período de Estágio Curricular Obrigatório na sétima etapa do curso de Pedagogia, em razão da realização de uma prática inadequada que causou profunda reflexão e suscitou a busca por respostas a questões sobre o que motiva ou justifica a manutenção de práticas infantilizadoras pelos docentes da educação de jovens e adultos. Essa questão se fez tão relevante que instigou outras inquietações e, a partir disso, tornou-se primordial para a realização desse trabalho de pesquisa.

Para realizar o diálogo entre as nossas hipóteses iniciais e os referenciais teóricos escolhidos para embasar as reflexões, foi necessário ir à busca de outros elementos para a complementação dos estudos. Para tanto, retornamos à escola na qual fizemos nosso estágio e, através de observação participante, vivenciamos, agora com um olhar dirigido e crítico, uma nova oportunidade de presenciar os impactos que a realização de práticas pedagógicas infantilizadoras provocam no fazer docente e, também, no processo de escolarização dos educandos da EJA. 
Durante a análise dos dados, novas inquietações surgiram, sendo a mais relevante delas a impossibilidade docente de perceber a presença da infantilização e a força da cultura escolar no próprio planejamento, nas ações cotidianas da sala de aula, nos materiais disponibilizados pelo educador e em suas atitudes ao interagir com a turma.

Compreendemos que há uma acomodação que é causada, também, pela ausência de aprofundamento de temáticas pertinentes à EJA e de contato com materiais adequados ao público jovem e adulto nos cursos de graduação em Pedagogia e nas licenciaturas de maneira geral. Apesar de os licenciandos saírem da graduação habilitados para atuar com jovens e adultos, são raras as abordagens das particularidades dessa modalidade de Educação Básica ao longo de sua formação inicial.

Uma distorção de olhar refere-se à maneira como as dificuldades que os educandos possuem são vistas pelos professores, que em sua maioria os rotulam como incapacitados e/ou com dificuldade de aprendizagem. Precisamos problematizar, com os docentes, o fato de não questionarem o quanto o modo como eles propõem o aprendizado está distante da realidade dos educandos jovens e adultos, culminando na dificuldade que os estudantes apresentam para aprender.

Também cabe ressaltar a importância da autoavaliação da prática pedagógica e a necessidade de diálogos sobre a prática entre docentes. Esse tema é relevante e também permeou esse estudo. Pensamos que, na medida em que os docentes cotidianamente refletirem sobre seu próprio trabalho, haverá avanços significativos para a mudança desta cultura. 


\section{REFERÊNCIAS}

DI PIERRO, M. C.; JOIA, O.; RIBEIRO, V. M. Visões da educação de jovens e adultos no Brasil. Cadernos CEDES, Campinas, v. 21, n. 55, p. 58-77, nov. 2001. Disponível em: <http://dx.doi.org/10.1590/S0101-32622001000300005>. Acesso em: 6 maio 2013.

DUARTE, R. Pesquisa qualitativa: reflexões sobre o trabalho de campo. Cadernos de Pesquisa, n. 115, p. 139-154, mar. 2002.

FÁVERO, O. Memória das campanhas e movimentos de educação de jovens e adultos (1947-1966). Rio de Janeiro: UFF, s.d., p. 2-22.

FERNANDES, C. Amorosidade. In: STRECK, D.; REDIN, E.; ZITKOSKI, J. J. (Org.). Dicionário Paulo Freire. Belo Horizonte: Autêntica, 2008. p. 35-38.

FREIRE, P. Pedagogia do oprimido. 17. ed. Rio de Janeiro: Paz e Terra, 1987.

GASKELL, G. Entrevistas individuais e grupais. In: GASKELL, G.; BAUER, M. W. (Org.). Pesquisa qualitativa com texto, imagem e som: um manual prático. Rio de Janeiro: Vozes, 2002. p. 65-89.

GODOY, A. Introdução à pesquisa qualitativa e suas possibilidades. $R A E-$ Revista de Administração de Empresas. São Paulo, v. 35, n. 2, p. 57-63, 1995.

JULIA, D. A Cultura escolar como objeto histórico. 2001. Disponível em: <http://www.rbhe.sbhe.org.br/index.php/rbhe/article/view/273>. Acesso em: 19 jun. 2013.

LOPES, M. G. R. A. A especificidade do trabalho do professor de Educação de Jovens e Adultos. In: MOURA, T. M. M. (Org.). Educação de jovens e adultos: currículo, trabalho docente, práticas de alfabetização e letramento. Maceió: EDUFAL, 2008, p. 93-112.

LÜDKE, M.; ANDRÉ, M. E. D. Abordagens qualitativas de pesquisa: a pesquisa etnográfica e o estudo de caso. In: ___. Pesquisa em educação: abordagens qualitativas. São Paulo: EPU, 1986. p. 11-24.

MOLL, J. Alfabetização de adultos: desafios à razão e ao encantamento. In: MOLL, J. (Org.) Educação de jovens e adultos. Porto Alegre: Mediação, 2004. p. 11-16. 
OLIVEIRA, E. D. Educação de jovens e adultos: sob as marcas do preconceito em torno do fracasso escolar. In: MOURA, T. M. M. (Org.). Educação de jovens e adultos: currículo, trabalho docente, práticas de alfabetização e letramento. Maceió: EDUFAL, 2008, p. 143-155.

OLIVEIRA, I. B. Reflexões acerca da organização curricular e das práticas pedagógicas na EJA. In: MOURA, T. M. M. (Org.). Educação de jovens e adultos: currículo, trabalho docente, práticas de alfabetização e letramento. Maceió: EDUFAL, 2008. p. 13-30.

OLIVEIRA, M. K. Jovens e adultos como sujeitos de conhecimento e aprendizagem. Revista Brasileira de Educação, São Paulo, v. 1, n. 12, p. 15-43, dez. 1999.

ORGANIZAÇÃO DAS NAÇÕES UNIDAS PARA A EDUCAÇÃO, A CINÊNCIA E A CULTURA. Marco de ação de Belém. Conferência Internacional sobre a Educação de Adultos VI. Brasília: Unesco, MEC, 2010. PINTO, A. V. Sete lições sobre educação de adultos. São Paulo: Cortez, 2010. p. 86-101.

TFOUNI, L. V. A escrita - remédio ou veneno? In: AZEVEDO, M. A.; MARQUES, M. L. (Org.). Alfabetização hoje. São Paulo: Cortez, 2001. p. 53-60. 


\section{6}

\section{Relações de gênero nos sites de jogos infantis: entre a beleza e a força}

Cristiane Luiza Abbud Flores

Discursos aparentemente comuns e simples, como, "menino não chora" ou "menina é mais sensível", são pronunciados e constantemente repetidos em qualquer lugar: na rua, na escola, no supermercado, no rádio, no programa de televisão e também nos ambientes familiares. Esses discursos não necessitam estar contextualizados para que os seus significados sejam entendidos; não é preciso exemplificar situações em que eles podem surgir para que possam ser problematizados, pelo contrário, remetem a uma referência de gênero: racionalidade para o homem e sensibilidade para a mulher. Nesse sentido, ressalto que muitas representações acerca do "ser homem" e do "ser mulher" podem ser visualizadas e vivenciadas em nossa sociedade constantemente. Nos diferentes lugares e momentos, os sujeitos são regulados, controlados e idealizados pelos discursos normativos, os quais determinam (mesmo que implicitamente) um comportamento adequado ou um determinado padrão para viver a masculinidade e a feminilidade. 
A padronização de tais comportamentos foi atribuída a partir das características biológicas das pessoas, ou seja, de acordo com o sexo foram estabelecidas determinadas maneiras que distinguiam o homem da mulher. No entanto, com as mudanças sociais e históricas, surgiram grupos feministas e estudiosos que passaram a questionar essas distinções e desmistificar essa "naturalidade" imposta pela biologia. A partir disso, os estudos e argumentos mostraram que as diferenças entre homens e mulheres são uma construção da sociedade, do contexto histórico e da cultura, não uma imposição do sexo biológico. Como salienta Guacira Lopes Louro (1995, p. 103),

[...] os sujeitos se fazem homem e mulher num processo continuado, dinâmico (portanto não dado e acabado no momento do nascimento, mas sim construído através de práticas sociais masculinizantes e feminilizantes, em consonância com as diversas concepções de cada sociedade).

Nesse caso, a maneira como a criança irá viver sua masculinidade ou feminilidade, no decorrer de sua vida, não está prescrita desde o seu nascimento, pelo contrário, as representações são estabelecidas no meio social e histórico. Cabe ressaltar que cada sociedade está inserida numa determinada cultura e também produz essa cultura, que se dissemina através das interações, operando com diferentes significados para as atitudes, crenças, costumes e comportamentos, inclusive em relação às expectativas sobre o feminino e o masculino (Carvalho; Tortato, 2009). Portanto, “[...] o conceito [de gênero] passa a exigir que se pense de modo plural, acentuando que os projetos e as representações sobre mulheres e homens são diversos" (Louro, 2003, p. 23). Desde o nascimento, a criança está inserida em uma rede de representações de etnia, raça, classe, sexualidade e gênero. Representações que incorporam a vida da criança e que delimitam o seu estilo de vida, seja através dos discursos e práticas vivenciadas por ela como também 
pelos diferentes artefatos culturais. Com relação ao gênero, a descoberta do sexo do bebê motiva e determina as representações de feminilidade e masculinidade através da decoração do quarto, das roupas e brinquedos que farão parte da vida da criança, e a constituirão como menina ou menino na sociedade. Esses artefatos induzem e retomam os comportamentos e as expectativas futuras que devem ser dirigidas à criança. Conforme Marília Gomes de Carvalho e Cíntia de Souza Batista Tortato $(2009$, p. 23),

[...] essas expectativas, para a maioria das pessoas, traduzidas nas cores e brinquedos dos enxovais, na decoração do quarto, na escolha dos acessórios e até na forma como a mãe se comunica com o bebê em seu ventre, já carregam as formas de entender o que é ser homem e o que é ser mulher e consequentemente o que será ensinado ao novo ser.

Nesse aspecto, ressalto que a família emprega na criança um ideal de vida que está relacionado com as representações de gênero, como atitudes, modos de agir e vestir que são transferidos através das interações entre as pessoas. Dessa forma, retomo a questão de que essas condutas não são determinadas biologicamente, mas fazem parte de um minucioso e constante processo de construção social, histórico e cultural. As crianças não distinguem o que é de uso apenas do seu sexo sem as intervenções dos adultos, pelo contrário, elas

[...] brincam de qualquer coisa e com qualquer objeto que lhes pareça interessante, sem fazer distinção preconceituosa: isso é de menino, isso é de menina. São os adultos que costumam interditar brincadeiras e brinquedos, gostos, gestos, comportamentos, determinando o que deve ser de menino ou de menina, limitando assim as possibilidades e a criatividade das crianças. (Felipe, 2011, p. 79). 
Dessa forma, é por meio dos discursos e das relações sociais nos diferentes espaços - como família, escola, mídia, filmes e demais pedagogias culturais - que as representações de gênero formam, socializam, educam e constituem as crianças. São nesses espaços que as aprendizagens acontecem e consequentemente produzem "verdades", isto é, alguns locais educativos utilizam-se da diversão, da brincadeira e do entretenimento para afirmar e posicionar esses sujeitos nas "adequações" impostas pela sociedade. Os artefatos culturais possuem o poder de legitimar tais conhecimentos sem que sejam questionados e, até mesmo, reconhecidos como produtores de "verdades". Assim como na escola, esses artefatos podem silenciar outras representações de gênero e, também, outras identidades, encarregando-se de normatizá-las a partir de uma referência. Por isso, ressalto a importância de questionar e problematizar as formas pelas quais as masculinidades e feminilidades estão sendo representadas, pois elas produzem estilos de vida, modos de viver e ser na sociedade. Dessa forma, os ensinamentos voltados às crianças não devem estar pautados na unificação dos sujeitos, em apenas uma parte considerada dominante, que, por sua vez, determina um padrão a ser seguido, mas na pluralidade das identidades de gênero, raça, etnia, classe e sexualidade que constituem a sociedade.

Ao definir como objeto desta pesquisa os jogos disponibilizados nos sites Joguinhos de Menino e Joguinhos de Menina, ${ }^{1}$ parto do entendimento de que estes são artefatos culturais e não apenas entretenimento infantil, pois os considero como (re)produtores de uma determinada cultura. De acordo com Tomaz Tadeu da Silva (1999, p. 134), “[...] a cultura é um campo onde se define não apenas a forma que o mundo deve ter, mas também a forma como as pessoas e os grupos devem ser". Desse modo, podemos pensar os sites e jogos como artefatos que reforçam as representações consideradas pela sociedade e pela sua

${ }^{1}$ Esses sites estão disponibilizados nos seguintes endereços eletrônicos: <www.joguinhosdemenino.com.br $>\mathrm{e}<\mathrm{www}$.joguinhosdemenina.com.br $>$. 
cultura como "verdadeiras" e "naturais", impondo, através da diversão e do prazer, os modos pelos quais as pessoas devem ser e viver. Assim, os jogos virtuais, como artefatos culturais, consistem em espaços sociais que educam, veiculam modos de ser e de se comportar, através das suas imagens, textos e vídeos. São, portanto, pedagogias culturais, assim como a mídia, as revistas, os filmes, os programas de TV, a publicidade, entre outros (Steinberg, 1997). Compreendo a internet como um espaço de informação, entretenimento e produção de conhecimento, no qual o usuário/a criança interage com dados, programas e sites disponibilizados, encontrando outras formas de socializar e de se construir como sujeito (Dornelles, 2007). Além disso, pretendo evidenciar que a internet, assim como a mídia, a publicidade, os filmes e os jogos que pesquisei são produtores de identidades sexuais e de gênero e que, por isso, não podem ser considerados apenas entretenimento e diversão, pois compreendo que as suas informações não são neutras, já que promovem indiretamente um modelo ideal de ser homem, mulher e criança em nossa sociedade.

Retomo a questão de que as representações estabelecidas pela sociedade podem ser visualizadas na internet através de textos, vídeos e imagens. Nesse sentido, os sites e jogos difundem, através de uma linguagem compreensível, divertida e visual, os "modelos" reconhecidos como legítimos e ideais, enquanto as demais representações são desconsideradas e silenciadas, pois, assim como ocorre em outras pedagogias culturais, a internet e seus múltiplos sites estão imersos em relações de hierarquização e poder. Através do poder, são fixadas as "verdades" e as representações de gênero, sexualidade, raça e etnia consideradas "certas" e válidas, isto é,

Quando indivíduos, grupos, tradições descrevem ou explicam algo em uma narrativa ou discurso temos a linguagem produzindo uma "realidade", instituindo algo como existente de tal ou qual forma. Assim, quem 
tem o poder de narrar pessoas, coisas, eventos ou processos, expondo como estão constituídos, como funcionam, que atributos possuem, é quem dá as cartas da representação, ou seja, é quem estabelece o que tem ou não tem estatuto de "realidade." (Costa, 2005, p. 141).

Com relação aos sites pesquisados, destaco que os discursos acerca dos gêneros podem ser identificados através da linguagem textual e visual. Especialmente em relação às imagens, Susana Cunha (2008, p. 110) observa que elas "[...] atuam e ensinam valores, normas, comportamentos, modos de ver e de ser", educando e (re)produzindo significados acerca do mundo para as crianças. Desse modo, as imagens possuem caráter pedagógico, pois ensinam e, consequentemente, contribuem para a construção das identidades infantis. A mesma autora utiliza o termo "visualidade" para designar os modos pelos quais construímos os olhares sobre o mundo (Cunha, 2007; 2008). Através das interações sociais e culturais, atribuímos significados ao mundo visual, assim, entende-se que as imagens, quando inseridas em instâncias educativas, são constituídas como pedagogia da visualidade, pois “[...] formulam conhecimentos e saberes que não são ensinados e aprendidos explicitamente, mas que existem, circulam, são aceitos e produzem efeitos de sentido sobre as pessoas" (Cunha, 2007, p. 136).

Nesse sentido, as interações entre as crianças e determinadas imagens farão parte do seu repertório pessoal, ou seja, algumas imagens farão parte da memória, das lembranças e servirão como referência do mundo que as cerca. Diante disso, ressalto a importância de analisar as imagens dos jogos para compreender como estão sendo representadas as identidades de gênero, já que é a partir de um espaço denominado infantil e de entretenimento que podem ser reforçados os modos de ser homem e mulher. Ao interagir com os jogos e suas imagens, a criança internalizará as representações ali existentes, o que poderá servir de modelo para a sua vida. Assim, se uma menina visualizar e interagir 
com uma personagem descrita como "bonita, simpática e ideal” e seus traços enfatizam um corpo magro, esbelto, cabelos loiros e olhos azuis, a compreensão desta menina sobre o que significa, na nossa cultura, ser uma mulher "perfeita" será a partir deste modelo.

Tanto a mídia quanto a publicidade e a internet encarregam-se de utilizar abordagens que exemplificam os padrões sociais, estéticos, corporais e comportamentais, porém tais abordagens são tidas como imparciais e naturais por resultarem das relações de poder inseridas em cada cultura. Portanto, para analisar os sites e os jogos neste trabalho, tenho como base o que Cunha (2010, p. 105) evidencia sobre as imagens: "Muito além de uma 'neutralidade', as imagens modelam nossos modos de ver, narram o mundo a partir de determinados pontos de vista, territorializam tribos, constroem e disputam significados”. Assim sendo, as imagens desses jogos modelam e constroem significados considerados "legítimos" acerca de como devem ser vividas a masculinidade e a feminilidade.

\section{QUE OS SITES \& JOGOS ENSINAM}

A escolha dos sites ocorreu pela nomeação de ambos, já que, através do nome, nota-se uma separação explícita e uma declaração de quem deve ser o usuário do espaço, assim, deixando o "outro" de fora desse universo. Os sites Joguinhos de Menina e Joguinhos de Menino possuem características diferenciadas em comparação um com o outro. Enquanto o site das meninas apresenta um ambiente predominado pelos diferentes tons de rosa, branco e verde, por desenhos de estrelas e uma caracterização voltada para a delicadeza, afetividade e romantismo, o dos meninos é composto por tons de azul, um design mais moderno, com pouca decoração e com diferentes ícones que transparecem um ambiente mais ágil e tecnológico. O referido site apresenta um menu composto por doze categorias, sendo que cinco podem ser denominadas como marcadores 
de masculinidade. São eles: arcade, ${ }^{2}$ corrida, luta, raciocínio lógico ${ }^{3}$ e tiro. Com exceção do raciocínio lógico, o qual entendo como uma sugestão de que os meninos são mais inteligentes do que as meninas e conseguem finalizar o jogo, reforço a ideia de que tais categorias promovem representações de gênero fortemente segmentadas, que chamamos de oposições binárias. Nesse sentido, destaco que há visibilidade para atitudes caracterizadas como fortes, agressivas, dinâmicas e ativas atribuídas "[...] ao homem, como se houvesse uma essência da qual fosse impossível escapar" (Bello; Felipe, 2010, p. 177), isto é, esses comportamentos passam a ser considerados naturais.

Do mesmo modo que aparece um menu de categorias no site dos meninos, há uma lista específica no site das meninas. Ela possui nomes direcionados para o universo feminino, o que enfatiza os marcadores de gênero fortemente presentes nestes sites. No entanto, algumas categorias (ação, aventura, esportes e simulador) estão incluídas em ambos os sites, o que as diferem são os seus conteúdos (os jogos). No site das meninas, o menu é composto por dezoito categorias de jogos, sendo elas: ação, aventura, Barbie, bebês, Bratz, cenário, colorir e pintar, culinária, esportes, habilidade, maquiagem, moda, pet shop, Polly Pocket, salão de beleza, simulador, Sue e Winx. É possível observar que aproximadamente seis podem ser reconhecidas como funções e profissões do sexo feminino, como, por exemplo, bebês, culinária, maquiagem, moda, pet shop, salão de beleza, o que remete as mulheres ao ambiente doméstico, ao cuidado de crianças e animais e ao culto e embelezamento do corpo.

${ }^{2}$ A descrição "arcade" é conhecida como jogos no estilo videogame.

${ }^{3}$ De acordo com a comparação realizada entre os dois sites, pude observar que a categoria "raciocínio lógico" encontra-se apenas no espaço referente aos meninos. Com isso, entendo que há uma representação de que os homens são mais inteligentes, mais aptos para o raciocínio lógico-matemático, bem como para o raciocínio espacial. 
Para a escolha dos jogos de cada site, foram selecionadas categorias consideradas como marcadoras de atitudes, comportamentos e características de homens e mulheres - luta, corrida, tiro e moda. No entanto, a categoria habilidades, em Joguinhos de Menina, fora selecionada para que fossem verificados que tipos de habilidades estariam sendo propostos para as meninas por meio desses artefatos. A partir disso, foram elencados os jogos que se assemelhavam às temáticas e selecionados dois de cada site para exemplificar as propostas encontradas na maioria deles. São eles: "Meu lindo jardim" (categoria habilidades) e "Colegiais líderes de torcida" (categoria moda), "Mort II" (categoria tiro) e "Trolls rage - a vingança do gnomo" (categoria luta).

O jogo "Meu lindo jardim" tem como proposta o cuidado com as flores que estão dispostas em vasos. A jogadora deve escolher no menu uma semente e inseri-la individualmente em cada vaso. Durante o jogo, a menina/jogadora deve adubar e colher as plantas, caso queira, pode continuar plantando. As ações realizadas pela jogadora ficam centradas nos cliques do mouse, isto é, com apenas alguns cliques, o plantio das sementes e os cuidados com as plantas são realizados. Cabe mencionar que a personagem que aparece no jogo não interage com a jogadora, já que seus movimentos são automáticos e não possuem relação com os cliques do mouse. Além disso, não há obstáculos ou ações que exijam raciocínio e atenção, o que promove questionamentos acerca dos tipos de habilidades que estão sendo sugeridos nessa categoria. $\mathrm{O}$ cenário desse jogo traz elementos considerados femininos: flores, um jardim organizado, instrumentos de jardinagem com enfeites e a caracterização "adequada" da personagem, ou seja, simpatia, meiguice e alegria estampadas no rosto, assim como vestimentas delicadas e com cores consideradas "femininas". 

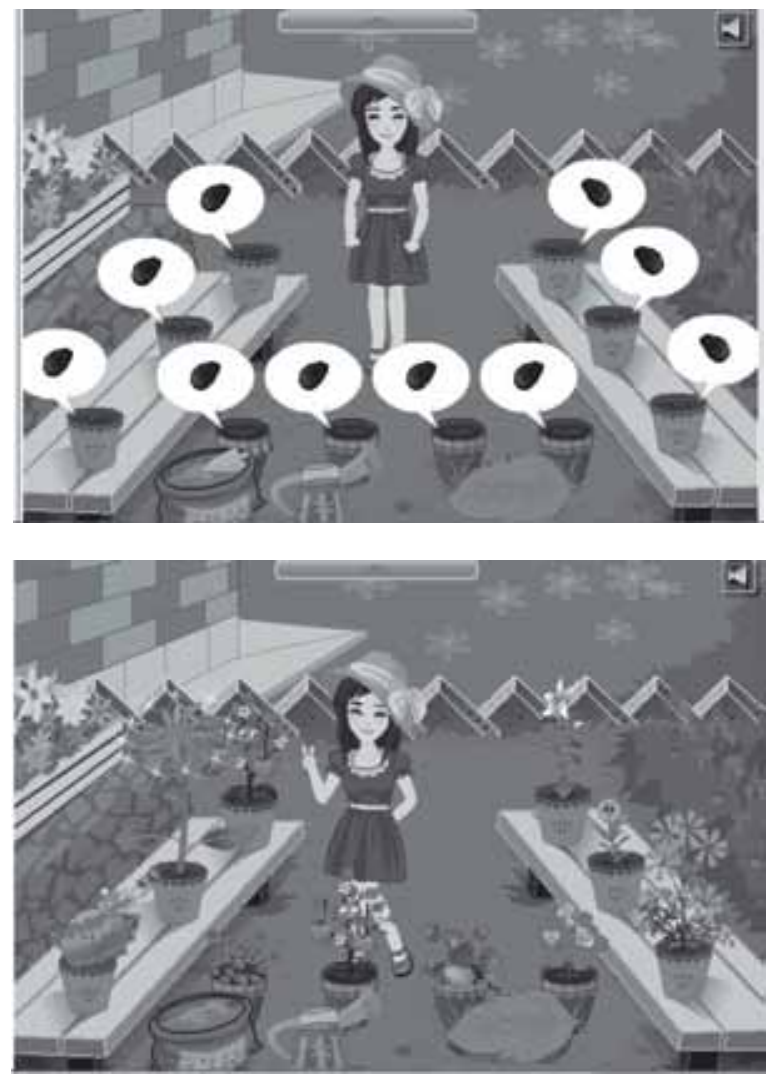

Figura 1 - Imagens do jogo "Meu lindo jardim" (plantio e colheita das flores - fim de jogo)

Com relação ao jogo "Colegiais líderes de torcida", a jogadora precisa escolher, dentre as inúmeras vestimentas disponibilizadas no armário (menu do jogo), uma para produzir a personagem escolhida. Ao final disso, esta personagem disputa a sua beleza e produção com outras duas líderes de torcida, sendo estabelecido um lugar no pódio (primeiro, segundo e terceiro lugar). Assim como "Meu lindo jardim", esse jogo não apresenta nenhum grau de dificuldade e exigência para as jogadoras. Pelo contrário, as escolhas e trocas de roupas e acessórios limitam-se apenas aos cliques do mouse, não promovendo a criatividade e a imaginação. Outros aspectos que destaco são a valorização do corpo 
magro, esbelto e atlético como referência para as crianças e, também, a competição voltada para a beleza e a popularidade. Ao referenciar este tipo de corpo, indiretamente está sendo estabelecido que este deve ser o padrão de beleza, fazendo com que as meninas apreciem e valorizem este modelo. Por outro lado, também aprendem que aquelas que não estão inseridas nesse padrão serão julgadas ou desvalorizadas.
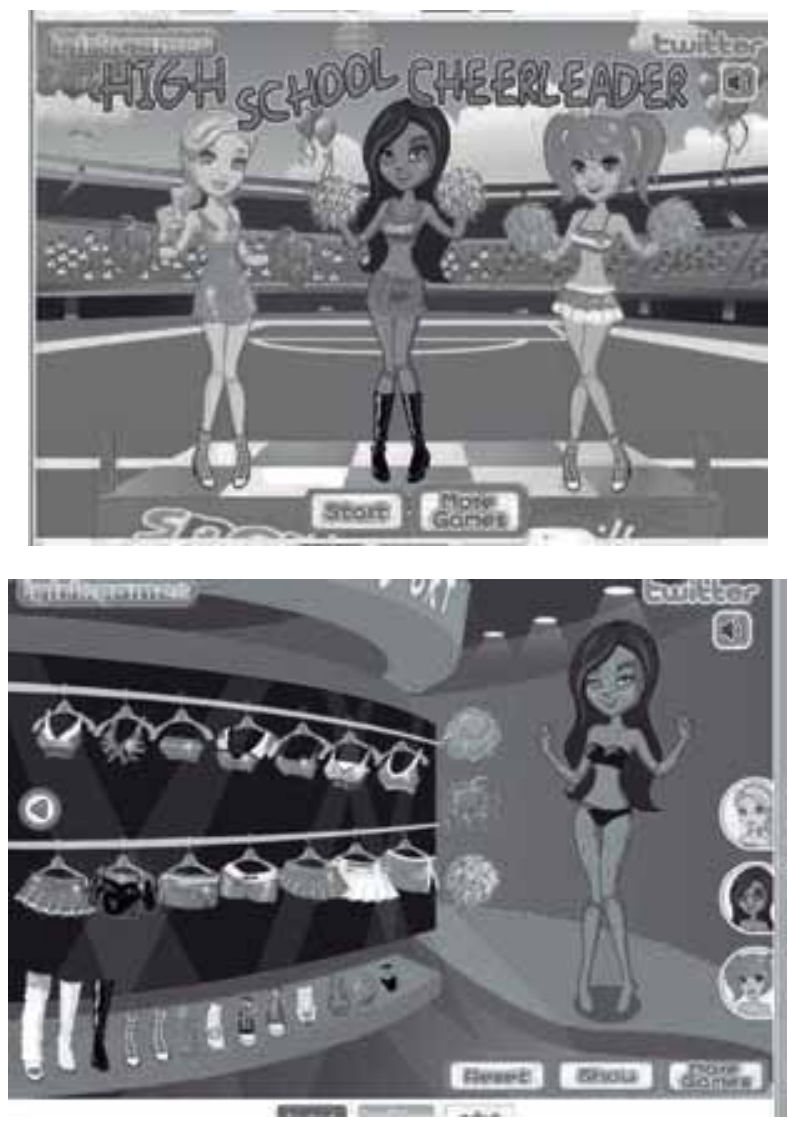

Figura 2 - Imagens do jogo "Colegiais líderes de torcida" (página inicial e escolha das vestimentas)

As representações de feminilidade observadas nesses jogos indicam, para as usuárias desse espaço, as características, os comportamentos e os valores adequados instituídos para as mulheres em nossa sociedade. Ao 
mostrar docilidade, meiguice, simpatia na caracterização das personagens, o cuidado com crianças, jardins e casa como objetivos, e a inserção de elementos românticos, como corações, estrelas e flores, nos cenários, esses jogos reforçam um modelo feminino de ser. Desse modo, essas representações e discursos, que descrevem as figuras femininas a partir de determinadas marcas sociais, "[...] constroem determinados significados e, assim, legitimam específicas identidades de gênero" (Rael, 2008, p. 167). A partir das interações que as crianças têm com tais jogos, imagens e discursos, vinculados nos diferentes artefatos culturais, é que são constituídas e afirmadas as identidades de gênero.

Outro aspecto importante a considerar se refere às representações de feminilidade que reforçam a posição social da mulher como cuidadora do lar e responsável pelas demais funções voltadas ao ambiente doméstico, o que é exposto no jogo "Meu lindo jardim”. Além de apresentar o cuidado com o jardim como uma atividade tipicamente feminina, este jogo indica possíveis profissões compatíveis com as mulheres, neste caso, há uma menção sobre o cuidado com a casa e com o jardim. Por meio disso, entendo que, mesmo que seja considerada e mencionada uma profissão para as mulheres, as questões domésticas estão sempre atreladas às suas vidas, isto é, as mulheres precisam conciliar profissão com afazeres domésticos e, quem sabe, escolher profissões que estejam vinculadas ao lar, como cozinheira, etc.

A partir de minhas análises, observei que os jogos "Meu lindo jardim" e "Colegiais líderes de torcida" retratam, ainda, duas representações corporais de mulheres. A primeira delas remete a uma figura feminina mais delicada, romântica e dócil, e as vestimentas dão continuidade a essas qualidades. Ao encontro disso, compartilho a ideia de Silvana Vilodre Goellner (2003) de que a feminização da mulher ocorre através da aparência e do uso de seu corpo, isto é, toda a sua composição corporal - incluindo a voz (ausência no caso do jogo), as atitudes, olhares, modos de se vestir - indica como deve ser essa feminilidade. 
Assim, essa imagem transmite para as meninas uma representação acerca de ser mulher e ser feminina perceptível na estrutura corporal da personagem, assim como nos seus olhos, roupas e gestos. Já com relação ao jogo "Colegiais líderes de torcida", há outro perfil de mulher demarcado, que pode ser considerado mais erótico e diz respeito ao excesso de preocupação com a aparência e com o embelezamento do corpo. Jane Felipe (2008) enfatiza que o corpo tornou-se o centro das atenções e passou a ser fabricado, esculpido e consumido pelas mulheres e meninas com a preocupação de se estar sempre bonita e atraente. No entanto, essa preocupação e “[...] o constante apelo à beleza [...] se expressa[m] através de um corpo magro e jovem [...]”, isto é, um modelo naturalizado de beleza e saúde (Felipe, 2008, p. 55). Mitificando a beleza, "Ser bela é ser atraente e sensual" e possuir um "corpo perfeito" (Goellner, 203, p. 49). Nesse jogo, a atividade ou profissão mencionada para as mulheres corresponde à de animadora de torcida, na qual prevalece a exposição do corpo. As personagens possuem corpos esbeltos, magros, de cintura fina; as roupas, acessórios e até mesmo o posicionamento do corpo e do olhar transmitem ousadia e sensualidade. Portanto, assim como ocorre em outras mídias, novelas e publicidade, esse jogo visibilizou um corpo juvenil de maneira erotizada, colocando-o como objeto de desejo e consumo por meio dos gestos, comportamentos e roupas (Felipe et al., 2012).

Dessa forma, entendo a importância de problematizar tais representações corporais, pois, indiretamente, as meninas que interagem com esses jogos e suas imagens internalizam esses perfis como sendo naturais. Além disso, essas "[...] imagens exercem poder sobre as mulheres e meninas porque ensinam como deve ser o seu corpo" e seus comportamentos (Nunes, 2010, p. 186). Assim como as representações de gênero, os corpos são produzidos através dos discursos e de práticas sociais, por meio de acessórios, inúmeros artefatos, gestos e atitudes, estabelecendo, assim, o que a sociedade considera normal, adequado (Louro, 2004). 
Portanto, é preciso pensar o corpo "[...] como um constructo cultural; [...] percebê-lo não apenas vinculado a sua natureza biológica, mas construído também na e pela cultura" (Figueira, 2008, p. 126).

Nesse sentido, entendo que as definições impostas, através das personagens, reforçam a ideia de que o corpo magro e esbelto é o adequado, principalmente ao referi-lo em um jogo de moda e competição. Além disso, os corpos que aparecem no jogo "Colegiais líderes de torcida" referem-se ao negro e ao branco, não aparecendo outro perfil (gordas, baixas, por exemplo) - o que reforça a ideia de que esse tipo de corpo caracteriza-se como "diferente" e pode ser ocultado/silenciado. De acordo com Guacira Lopes Louro (2001, p. 89) "[...] o silenciamento parece ter por fim 'eliminar' esses sujeitos [...]. A negação e a ausência aparecem, nesse caso, como uma espécie de garantia da 'norma'." Retomo a ideia de que esses jogos reforçam as características desejadas e esperadas para as mulheres, além de destacar a fragilidade e a docilidade como atributos exclusivamente femininos e de desconsiderar aspectos cognitivos.

Em contrapartida aos jogos selecionados no site das meninas, os jogos "Trolls rage - a vingança do gnomo" e "Mort II" possuem finalidades e dinâmicas opostas ao que foi observado nos anteriores. "Trolls rage - a vingança do gnomo" tem como personagem principal um gnomo gigante que matava os humanos para entregar aos goblins, ${ }^{4}$ no entanto, após ficar muito tempo preso, libertou-se e decidiu se vingar. Para continuar livre, ele precisa matar todos os goblins que aparecem em seu caminho. É possível perceber que o jogo se caracteriza pelas cores fortes e escuras e a fisionomia do personagem transmite raiva e ódio. Além disso, o machado que o gnomo utiliza para matar seus inimigos contém marcas de sangue; o cenário e os ataques executados pelo jogador configuram e reforçam a ideia de agressividade, seriedade e terrorismo. Ao longo do jogo, surgem mensagens na tela indicando o grau de violência cometido nos ataques. Por exemplo,

${ }^{4}$ Goblins: personagens criados através de lendas. São criaturas semelhantes aos duendes, no entanto fazem brincadeiras de mau gosto. 
quando o personagem apenas golpeia o seu "inimigo", o movimento é caracterizado como raivoso, porém, se o mata, é considerado destrutivo. Nesse sentido, entendo que o jogo transmite, mesmo que involuntariamente, a ideia de que a vingança e a força brutal podem ser consideradas como mecanismos de defesa e de resolução de problemas; outras maneiras de solucioná-los tornam-se secundários.
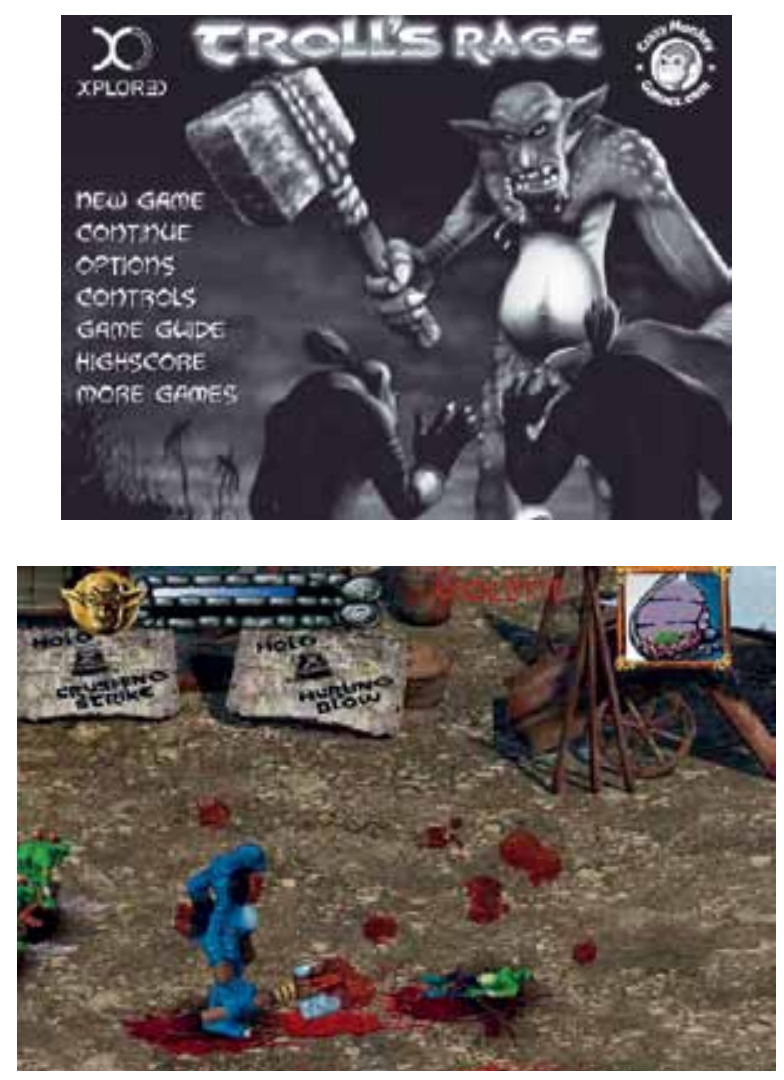

Figura 3 - Imagens do jogo "Troll's rage - a vingança do gnomo" (página inicial e golpes desenvolvidos ao longo do jogo)

Outro elemento a ser destacado corresponde às habilidades a serem desenvolvidas nesse jogo. Para que o objetivo seja cumprido, o jogador necessita de atenção e rapidez para executar os movimentos no momento correto. Dessa forma, compreendo que os jogos para os meninos 
exigem raciocínio e outras habilidades, pois permitem que eles criem estratégias e busquem as melhores ações para finalizá-lo - ao contrário dos critérios de habilidades exigidas das meninas.

Já o jogo "Mort II" possui como personagem principal um homem branco, forte e sério, cuja profissão é atirador de elite e que tem por objetivo eliminar as gangues da cidade e soltar os reféns. Após uma história introdutória, o jogador depara-se com a primeira gangue a ser eliminada e, para que não seja morto, ele precisa pensar em uma estratégia de ataque. A partir disso, retomo a questão de que a conclusão desse jogo baseia-se no raciocínio e na atenção do jogador, pois as suas ações devem ser pensadas e analisadas conforme a cena e a disposição dos personagens.
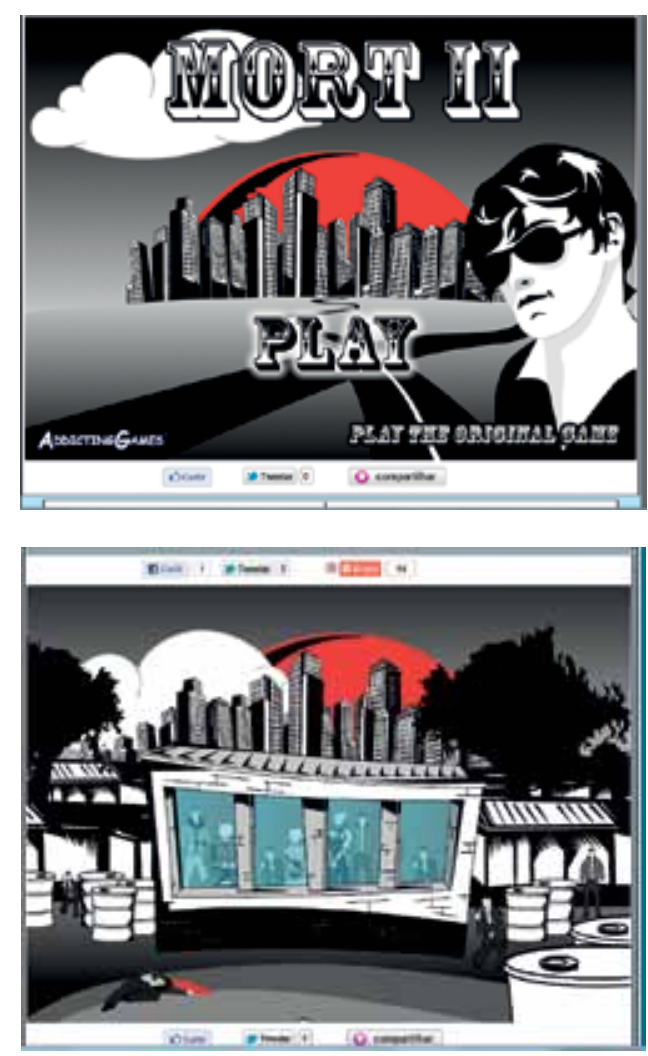

Figura 4 - Imagens do jogo "Mort II" (página inicial e ações desenvolvidas ao longo do jogo). 
O estilo desse jogo tem como características a seriedade e a neutralidade. Ao contrário do "Trolls rage - a vingança do gnomo", "Mort II" tem como composição um cenário urbano nas cores branca, preta e, para destacar o sangue dos inimigos, vermelho. Conforme é atingido o objetivo, o jogador transfere-se para outra fase e para outras exigências e dificuldades. Pude observar que as representações de masculinidade neste jogo destacam a violência como uma atitude aceitável para resolver os problemas. Além disso, vale também ressaltar que este jogo direciona, para meninos e homens, profissões consideradas dinâmicas, ágeis, intensas e que exijam raciocínio, inteligência, seriedade e habilidade.

Tais jogos instauram representações de masculinidade através de inúmeros elementos, como as cores neutras e fortes, os cenários radicais, os movimentos agressivos e intensos dos personagens e as estratégias a serem executadas e pensadas que visam ao raciocínio, à atenção e ao treino de habilidades motoras do jogador. Nesse sentido, entendo que esses elementos transmitem um modelo naturalizado de como um homem deve ser e viver no mundo, partindo da compreensão de que força, racionalidade, inteligência e seriedade são características biológicas desse sexo. Dessa forma, esses jogos priorizam uma representação como sendo legítima e excluem as demais maneiras de viver as masculinidades.

Assim como existem diferentes formas de ser mulher, existem diferentes formas de ser homem (Bello; Felipe, 2010). No entanto, há uma vigilância constante e reiterada em torno da masculinidade infantil como uma forma "[...] de garantia para a masculinidade adulta [...]" (Felipe; Guizzo, 2008, p. 34). Com isto, os meninos são educados para viver a masculinidade de uma determinada forma, já que as outras diferentes identidades são silenciadas e desvalorizadas. Através destes elementos e discursos encontrados nos diferentes artefatos culturais, as representações de masculinidade são constituídas e estabelecidas como padrão. 
Os jogos em análise neste artigo transmitem, por meio de suas imagens e enunciados, significados acerca do mundo, dos homens e das mulheres, das classes sociais, de raça e etnia, nos quais reforçam e regulam as identidades infantis. Cunha $(2008$, p. 110) ressalta que as imagens "[...] atuam e ensinam valores, normas, comportamentos, modos de ver e ser”, por isso, quando as crianças interagem com as imagens, estas fornecem modelos para serem seguidos e reproduzidos por aquelas. Portanto, assim como em outras pedagogias culturais, os sites e jogos voltados para o público infantil repassam os significados que foram construídos e legitimados ao longo do processo cultural e social, ilustrando as expectativas em torno das masculinidades e feminilidades.

\section{ALGUMAS CONSIDERAÇÕES...}

Como foi possível observar, os sites e jogos analisados compõem-se de imagens que seduzem os usuários pelas decorações, cenários atrativos, coloridos ou, até mesmo, com cores neutras. São imagens que podem passar despercebidas aos olhares das crianças e dos adultos, pelo simples fato de estarem inseridas em um ambiente infantil. No entanto, retomo a ideia de que esses artefatos não são neutros nem ingênuos, pois utilizam as decorações, ilustrações e personagens - inclusive conhecidos das crianças - para transmitir mensagens relacionadas às questões de gênero, como também de raça e etnia. Por se tratar de um espaço de entretenimento e diversão, essas mensagens são absorvidas pelo público infantil e tornam-se referências, tanto no aspecto estético como corporal e comportamental. Por meio dos personagens e de suas características marcantes, com gestos, comportamentos e aparência envolventes, determinados modelos de masculinidade e feminilidade são ensinados e reforçados.

A composição destes artefatos demonstra que as crianças estão imersas em espaços que se incubem de promover a normalização e a naturalização dos sexos e dos seus possíveis comportamentos. Dessa 
forma, remete-se à ideia de que a mulher deve ser feminina, simpática, emotiva e responsável pelos trabalhos domésticos, enquanto o homem deve ser mais racional, forte, ágil, entre outras características. Portanto, os modelos impostos nos jogos analisados aqui enfatizam pensamentos originados da biologia/natureza humana, sustentando a tese de que a mulher é o oposto em comparação ao homem. Ao encontro disso, Guacira Lopes Louro (2000b, p. 41) comenta:

[...] o género feminino é descrito pela sua diferença
em relação ao masculino. É frequente ouvir dizer-se
que as mulheres são mais fracas do que os homens [...]
"constata-se" que nós mulheres, somos diferentes
deles, os homens. [...] não importa de onde vêm as
argumentações (embora evidentemente tenham forças
argumentativas e efeitos sociais diversos), mas interes-
sa acentuar que a norma, o referente, a regra face à qual
se estabelece uma relação para "mais" ou para "menos"
é o género masculino.

Os comportamentos, as atitudes e os modos de ser e viver a feminilidade são delimitados a partir das considerações acerca da masculinidade, ou seja, tudo que for designado para os homens terá o seu oposto direcionado para as mulheres, já que "[...] o ideal feminino vai se constituir a partir da lógica binária do masculino/feminino, onde o primeiro termo é valorizado e se opõe ao segundo termo [...]" (Rael, 2008, p. 165). Assim, o site dos meninos evidencia uma decoração neutra, com poucos elementos e com jogos direcionados para ações mais agressivas, que exijam força dos seus personagens. Em contrapartida, o das meninas invoca um ambiente mais colorido, com elementos decorativos e com seus jogos centrados em atividades mais calmas, menos dinâmicas. Portanto, através de minhas análises, entendo que esses ambientes são distintos e, por se configurarem através de temáticas diferenciadas, reforçam a ideia de que homem e mulher são opostos e necessitam de brincadeiras e espaços separados. Assim, concordo com 
a afirmação de Felipe e Guizzo (2008, p. 34): “[...] meninos e meninas seguem suas vidas aprendendo que devem estar em mundos separados, que suas experiências não devem ser compartilhadas com o que consideram sexo oposto".

Desse modo, é através da escola, da família e das diferentes pedagogias culturais que as crianças constituem suas identidades sexuais e de gênero, raça, etnia, entre outras. Cabe ainda ressaltar que "[...] a constituição de cada pessoa deve ser pensada como um processo que se desenvolve ao longo de toda a vida em diferentes espaços e tempos" (Felipe; Guizzo, 2008, p. 33). Com isso, entendo que esses sites e jogos reforçam as representações estabelecidas cultural e socialmente; as crianças, por seu turno, ao interagirem com esses artefatos, internalizam tais representações, passando a considerá-las como naturais e legítimas. Por fim, destaco a importância de problematizar os diferentes artefatos, principalmente aqueles destinados ao público infantil, para que possam ser analisadas as representações de gênero instauradas através das imagens, textos, músicas, etc. Os sites e jogos infantis, assim como outras pedagogias culturais, utilizam-se do entretenimento para reforçar algumas práticas e características tidas como naturais. Assim, as crianças interagem não apenas com jogos divertidos, mas com jogos que educam indiretamente para serem homens e mulheres em nossa sociedade, de acordo com as expectativas construídas para cada um deles.

\section{REFERENNCIAS}

BELLO, A. T.; FELIPE, J. Delineando masculinidades desde a infância. Instrumento: Revista de Estudo e Pesquisa em Educação, Juiz de Fora, v. 12, n. 2, p. 175-182, jul./dez. 2010. Edição especial - Gênero, sexualidade e educação. 
CARVALHO, M. G.; TORTATO, C. S. B. Gênero: considerações sobre o conceito. In: LUZ, N. S.; CARVALHO, M. G.; CASAGRANDE, L. S. (Org.). Construindo a igualdade na diversidade: gênero e sexualidade na escola. Curitiba: UFPR, 2009. p. 21-32.

COSTA, M. V. Poder, discurso e política cultural: contribuições dos estudos culturais ao campo do currículo. In: LOPES, A. C.; MACEDO, E. (Org.). Currículo: debates contemporâneos. 2. ed. São Paulo: Cortez, 2005. p. 133-149.

CUNHA, S. R. V. Cultura visual e infância. In: ICLE, G. (Org.). Pedagogia da arte: entre-lugares da criação. Porto Alegre: Editora da UFRGS, 2010. p. 103-134.

. Entre Van Goghs, Monets e Mônicas: a infância educada através de imagens. Ciências e Letras: Revista da Faculdade de Educação Porto Alegrense, Porto Alegre, n. 43, p. 107-123, jan/jun. 2008.

. Pedagogias de imagens. In: DORNELLES, L. V. (Org.). Produzindo pedagogias interculturais na infância. Petrópolis: Vozes, 2007. p. 113-144.

DORNELLES, L. V. Apresentação: produzindo pedagogias interculturais na infância. In: DORNELLES, L. V. (Org.). Produzindo pedagogias interculturais na infância. Petrópolis: Vozes, 2007. p. 7-17

FELIPE, J. Erotização dos corpos infantis. In: LOURO, G. L.; FELIPE, J.; GOELLNER, S. V. (Org.). Corpo, gênero e sexualidade: um debate contemporâneo na educação. 4. ed. Petrópolis: Vozes, 2008. p. 53-65.

- Para discutir sexualidade e relações de gênero na infância. In: CÓRDULA, A.; BASTOS, A.; FELIPE, J. O educador como propositor e executor da política de educação infantil. Brasília: Gerdau, Fundação Sirotsky Sobrinho, 2011. p. 74-85. (Mesa educadora para a primeira infância).

FELIPE, J. et al. Erotização dos corpos infantis, pedofilia e pedofilização na contemporaneidade. In: Seminário GRUPECI, 3, 2012, Sergipe. Anais... Aracaju: Universidade Federal de Sergipe, 2012. CD ROM. 
FELIPE, J.; GUIZZO, B. S. Entre batons, esmaltes e fantasias. In: MEYER, D.; SOARES, R. (Org.). Corpo, gênero e sexualidade. 2. ed. Porto Alegre: Mediação, 2008. p. 31-40.

FIGUEIRA, M. L. M. A revista Capricho e a produção de corpos adolescentes femininos. In: LOURO, G. L.; FELIPE, J.; GOELLNER, S. V. (Org.). Corpo, gênero e sexualidade: um debate contemporâneo na educação. 4. ed. Petrópolis: Vozes, 2008. p. 124-135.

GOELLNER, S. V. Bela, maternal e feminina: imagens da mulher na revista Educação Phisica. Ijuí, Rio Grande do Sul: Unijuí, 2003. 152 p.

LOURO, G. L. Corpo, escola e identidade. Educação e Realidade, Porto Alegre, v. 25, n. 2, p. 59-76, jul./dez. 2000a.

. Currículo, género e sexualidade. Porto: Porto Editora, 2000b.

. Gênero, sexualidade e educação: uma perspectiva pós-estruturalista. 6. ed. Petrópolis: Vozes, 2003.

. O currículo e as diferenças sexuais e de gênero. In: COSTA, M. V. (Org.). O currículo nos limiares do contemporâneo. 3. ed. Rio de Janeiro: DP\&A, 2001. p. 85-92.

. Gênero, história e educação: construção e desconstrução. Educação e Realidade, Porto Alegre, v. 20, n. 2, p. 101-132, jul./dez. 1995.

. Marcas do corpo, marcas do poder. In: (Org.). Um corpo estranho: ensaios sobre a sexualidade e teoria queer. Belo Horizonte: Autêntica, 2004. p. 75-90.

NUNES, L. B. A cultura visual nas tramas escolares: a produção da feminilidade nas salas de aula. In: MARTINS, R.; TOURINHO, I. (Org.). Cultura visual e infância: quando as imagens invadem a escola... Santa Maria: UFSM, 2010. p. 165-190.

RAEL, C. C. Gênero e sexualidade nos desenhos da Disney. In: LOURO, G. L.; FELIPE, J.; GOELLNER, S. V. (Org.). Corpo, gênero e sexualidade: um debate contemporâneo na educação. 4. ed. Petrópolis: Vozes, 2008. p. 160-171. 
SILVA, T. T. Os estudos culturais e o currículo. In: Documentos de identidade: uma introdução às teorias do currículo. Belo Horizonte: Autêntica, 1999. p. 131-138.

STEINBERG, S. Kindercultura: a construção da infância pelas grandes corporações. In: SILVA, L. H.; AZEVEDO, J. C.; SANTOS, E. S. (Org.). Identidade social e a construção do conhecimento. Porto Alegre: Secretaria Municipal de Educação de Porto Alegre, 1997. p. 98-145. 


\section{"¿u não escuto nada, só vejo":}

narrativas sobre "ser surdo"

e a educação bilíngue

\section{Priscila de Abreu Bortoletti}

O presente texto é um recorte do meu Trabalho de Conclusão do Curso (TCC) de Pedagogia, no qual apresento análises de narrativas registradas em nove vídeos produzidos pelos acadêmicos do curso de Letras-Libras, turmas de 2010, na disciplina de Literatura Surda. É interessante enfatizar que o trecho de um dos vídeos que compõem o bloco analítico originou o título deste trabalho por seu caráter significativo de expressão da principal marca surda: a experiência visual.

É uma pesquisa qualitativa de vertente documental em que o objetivo, filiado ao campo dos Estudos Culturais em Educação e Estudos Surdos, foi investigar, nas produções culturais surdas, as narrativas sobre "ser surdo" e sua relação para a construção da educação bilíngue. A partir dessas produções literárias - que abrangem as seguintes narrativas: contos, poemas e fábulas em Língua Brasileira de Sinais (Libras) -, discuto: como estão narrados os modos de ser surdo nas produções culturais surdas e como podem contribuir para a construção da educação bilíngue para surdos? 
Para tanto, há três blocos analíticos, organizados a partir de duas unidades de análise: diferença e educação, que apresentam as discussões referentes à questão de pesquisa, visando ao alcance do objetivo do estudo. Esses blocos abrangem as narrativas selecionadas, em que foram analisados os modos de "ser surdo" narrados nesses vídeos, assim como os aspectos educacionais evidenciados neste material, que contribuíram para a construção da educação bilíngue que almejam.

Nesse sentido, destaca-se a ideia do sujeito surdo constituído pela experiência visual, com identidade e cultura envolvidas pela perspectiva da diferença. As narrativas contribuem para o pensamento de uma proposta educacional bilíngue que privilegie tais referências.

\section{CURSO DE LETRAS-LIBRAS: ESPAÇO \& SUJEITOS DA PESQUISA}

$O$ curso de Letras-Libras ${ }^{1}$ onde foram produzidos os vídeos analisados oferece duas modalidades: Licenciatura e Bacharelado. Esse curso é uma iniciativa da Universidade Federal de Santa Catarina (UFSC), responsável pela formação de profissionais na Língua Brasileira de Sinais para o ensino da Libras ou tradutores-intérpretes. Na modalidade de ensino a distância, as turmas iniciaram em 2008, tendo quinze polos institucionais no Brasil. Deste total, dez turmas disponibilizaram suas produções em vídeo para uso no projeto de pesquisa ${ }^{2}$ de que eu participava. Este curso tem um currículo marcado pela experiência visual, que proporciona a aproximação e a convivência com outros surdos, constituindo um sentimento de pertencimento à comunidade.

Este texto está situado em um espaço que envolve surdos e simpatizantes ouvintes, no caso, a maioria dos intérpretes, pertencentes à comunidade surda e envoltos por discursos da diferença. Minha intenção

\footnotetext{
${ }^{1}$ Mais informações sobre o curso podem ser obtidas em sua página na internet: $<$ http://www.libras.ufsc.br/>.

${ }^{2}$ Refiro-me à pesquisa "Produção, circulação e consumo da cultura surda brasileira", "Pró-cultura", a partir da qual pensei o objeto de estudo.
} 
não é generalizar, apontando que todos os surdos defendem a concepção que apresento ao longo desta escrita, sendo usuários da língua de sinais e tendo uma identidade surda, pois, como enfatiza Skliar (2010, p. 14),

\begin{abstract}
[...] Às vezes, ao falar dos "surdos" podemos, involuntariamente, descrever somente os surdos homens, brancos, de classe média, que frequentam as instituições escolares, que fazem parte dos movimentos de resistência, que lutam pelos seus direitos linguísticos e de cidadania, etc. [...] Seria um equívoco conceber os surdos como um grupo homogêneo, uniforme, dentro do qual sempre se estabelecem sólidos processos de identificação.
\end{abstract}

Há diferentes experiências de pessoas surdas: aquelas que preferem oralizar, aquelas que não frequentam as comunidades surdas, entre outras. Mas o recorte aqui feito é em um espaço de acadêmicos do curso de Letras-Libras, formados por surdos e ouvintes, usuários da Libras, que compartilham da mesma concepção com relação à educação e cultura surda e, na sua maioria, pertencem a comunidades e movimentos surdos.

Desse modo, os acadêmicos do curso de Letras-Libras, a partir da realização do trabalho final na disciplina de Literatura Surda, em 2010, construíram narrativas registradas em suporte digital (vídeos), potencializando a cultura surda através de artefatos que emergem de diferentes polos e regiões brasileiras. Desenvolvidas de forma individual ou em grupo, essas produções foram enviadas para a professora ${ }^{3}$ responsável da disciplina Literatura Surda e tabuladas em uma planilha, assim como os vídeos foram guardados em um arquivo, formando o banco de dados do Pró-cultura. Foi a partir deste banco de dados que selecionei o material empírico para desenvolvimento do estudo em questão.

\footnotetext{
${ }^{3}$ Coordenadora do grupo de pesquisa "Pró-cultura".
} 


\section{CONCEPÇÕES SOBRE A EDUCAÇÃO DE SURDOS}

A Educação de Surdos é fundamentada no campo dos Estudos Culturais em Educação, por entender a cultura como campo de luta em torno de significação social, e nos Estudos Surdos, por conceber a cultura surda como espaço de contestação e de constituição de identidades e diferenças que determinam a vida de indivíduos e de populações. Conforme Nídia de Sá (2002, p. 8), “[...] a educação de surdos continua sendo um território repleto de incompreensões, contradições e contrastes". Isso acontece devido às discussões geradas em torno do reconhecimento e valorização de sua língua, cultura, identidade e reivindicação de uma educação bilíngue para surdos, voltados para o viés da diferença. Esses discursos são próprios das comunidades que se sentem pertencentes a uma identidade diferenciada, sendo um deslocamento do olhar da deficiência - visão clínica - para um olhar mais cultural.

Tomei para esta escrita a concepção de surdez na perspectiva da diferença, conforme apresentada por Skliar (2010, p. 6), que entende a diferença como:

[...] significação política, é construída histórica e socialmente; é um processo e um produto de conflitos e movimentos sociais, de resistências às assimetrias de poder e de saber, de uma outra interpretação sobre a alteridade e sobre o significado dos outros no discurso dominante.

Assim, há um deslocamento do discurso da Educação Especial, viés focado na deficiência, "falta de algo", para uma visão cultural, presente na perspectiva educacional dos surdos.

Posso afirmar que, há não muito tempo, o surdo passou a ser compreendido como um sujeito linguística e culturalmente diferente, pelo uso de uma língua reconhecida na Lei no 10.436/02: a Língua Brasileira de Sinais - Libras. Essa lei reconhece a "[...] Libras como meio de 
comunicação e expressão [...]" (Brasil, 2008, p. 4). Dessa forma, o surdo passou a se constituir como um sujeito da experiência visual, que "fala com as mãos e ouve com os olhos", por essa ser, como ressalva Sá (2002), uma das formas de obter informação e compreensão do que acontece no seu entorno.

As lutas são contínuas pela valorização da língua e pelo reconhecimento da cultura surda, pois a língua é uma marca cultural. Nesse campo de estudo, cultura representa modos de vida na comunidade surda dentro de uma sociedade ouvinte. Essa cultura constitui a identidade surda, que é o modo de "ser surdo" e que vai além da forma de comunicação. Conforme Perlin (2004, p. 78): “A cultura surda é o lugar para o sujeito surdo construir sua subjetividade de forma a assegurar sua sobrevivência e a ter seu status quo diante das múltiplas culturas, múltiplas identidades".

Durante muitos anos, os surdos foram - e ainda são - submetidos a práticas oralistas, pertencentes ao modelo clínico, nas quais era defendida uma educação firmada pela integração dos surdos à sociedade ouvinte, através da oralização. Os movimentos surdos querem escolas bilíngues, que privilegiem o ensino por meio da língua de sinais. Como esses movimentos estão se fortalecendo, e, cada vez mais, suas reivindicações estão sendo amparadas pela lei, as escolas estão tendo que atender a questão do bilinguismo. O documento intitulado "Política nacional de Educação Especial na perspectiva da educação inclusiva” (2008), que cita o Decreto $n^{\circ} 5.626 / 05$, que regulamenta a Lei no $10.436 / 02$, afirma que sua aprovação visa ao acesso de alunos surdos à escola regular, por dispor sobre:

[...] a inclusão de Libras como disciplina curricular, a formação e a certificação de professor, instrutor e tradutor/intérprete de Libras, o ensino da Língua Portuguesa como segunda língua para alunos surdos e a organização da educação bilíngue no ensino regular. (Brasil, 2008, p. 4). 
Entretanto, para que haja uma educação bilíngue, não basta o uso da língua por meio do intérprete, pois a Libras é uma língua completa, que se difere da língua falada, no caso a Língua Portuguesa. A língua de sinais, ao ser produzida, basicamente pelas mãos, apresenta parâmetros, isto é, “[...] propriedades de configuração de mãos, movimentos, locações, orientações de mão e dos aspectos não manuais dessa língua” (Quadros; Karnopp, 2004, p. 50).

Assim, essa pedagogia da diferença envolve a valorização da língua, da cultura e, principalmente, da experiência visual, pois é dessa experiência que surge a cultura surda, "[...] representada pela língua de sinais, pelo modo diferente de ser, de se expressar, de conhecer o mundo, de entrar nas artes, no conhecimento científico e acadêmico." (Perlin; Miranda, 2003, p. 218). Este contexto visual constitui as identidades surdas, apontando para a questão de que elas "são construídas dentro das representações possíveis da cultura surda, elas moldam-se de acordo com a maior ou menor receptividade cultural assumida pelo sujeito" (Perlin, 2004, p. 77).

Destaco, novamente, que me refiro a um grupo específico, tendo um material de caráter instrucional que narra modos de "ser surdo", transmitidos através da literatura. Nas produções literárias em Libras analisadas, esses acadêmicos apontam suas críticas assim como os modos de "ser surdo" pelo olhar cultural e da diferença. Os objetos de estudos são vídeos em Libras, e as ferramentas de análise são as narrativas. 


\section{OS PASSOS DA PESQUISA:}

\section{TRABALHANDO COM O MATERIAL EMPÍRICO}

Para a etapa analítica, a partir dos 183 vídeos catalogados no banco de dados do Pró-cultura, foram selecionadas as narrativas sobre "ser surdo" ${ }^{4}$ e educação bilíngue na contemporaneidade. Para tanto, inicialmente, agucei meu olhar para as recorrências presentes nos títulos e, em seguida, detive minha atenção nas sinopses dessas produções culturais. A partir das recorrências encontradas, surgiram duas unidades analíticas: "diferença" e "educação", sendo selecionados nove vídeos. Suas narrativas se tornaram objetos de estudo e de representatividade de alguns ensinamentos e abordagens presentes e subjetivadas neles. Estes vídeos foram assistidos e traduzidos da Libras para a Língua Portuguesa.

Os conteúdos dos vídeos estão ligados às experiências históricas da educação dos surdos, bem como a reivindicações e resistências às imposições da contemporaneidade, ou seja, há a utilização da narrativa "[...] como testemunho da experiência vivida, e essa narrativa da experiência como legitimadora de uma determinada identidade [...]" (Silveira, 2005, p. 206). Com isso, é pertinente considerar que essas produções literárias estão carregadas de marcas culturais, devido às diferentes experiências vivenciadas pelos integrantes que as produziram, sendo interessante, então, ressaltar que há diferentes representações presentes nestes artefatos que subjetivam os modos de "ser surdo". Assim, foram desdobrados, de forma descritiva e analítica, os modos de "ser surdo" delineados nas narrativas destacadas.

\footnotetext{
${ }^{4}$ Tratado neste trabalho como um aspecto vivencial: "[...] ser surdo como um conceito fluido onde a epistemologia esgota o conhecimento presente na essencialidade da comunidade surda e não mais o conceito da deficiência, da clinicalização, da cura, da incapacidade [...]." (Perlin; Miranda, 2003, p. 218).
} 


\section{NARRATIVAS SURDAS - CAPTURANDO MODOS DE "SER SURDO"}

As narrativas analisadas apresentam reflexões acerca do "ser surdo", termo definido como uma "questão de vida", que significa ter uma experiência visual. Experiência que promove a comunicação por meio da visão e cria, assim, a cultura surda (Perlin, Miranda, 2003). Há histórias que contêm comparações entre surdos e ouvintes. Nelas é percebido que: "A distinção entre surdos e ouvintes envolve mais que uma questão de audiologia, é uma questão de significado: os conflitos e diferenças que surgem referem-se à forma de ser" (Sá, 2002, p. 49).

Ao assistir a essas narrativas contadas em Libras e selecioná-las do banco de dados do Pró-cultura, foi possível destacar, inicialmente, que as variações linguísticas presentes nas produções reafirmam a singularidade e as diferenças dialetais existentes em cada estado deste país. Isso demonstra que a Libras, “[...]como qualquer outra língua, está sujeita às variações regionais, adequando-se aos aspectos históricos, sociais e culturais das diferentes comunidades em que é utilizada" (Karnopp; Klein; Lunardi-Lazzarin, 2011, p. 21). Sendo assim, os vídeos por si só já apresentam a complexidade que envolve esta língua bem como as demais existentes no mundo, reafirmando sua legitimidade linguística. Além disso, é notável que a maioria dos acadêmicos do curso de Letras-Libras usou a literatura surda como uma maneira de apontar suas críticas e salientar os modos de ser surdo pelo olhar cultural e da diferença.

Nessa perspectiva, as narrativas em estudo são contos, fábulas e poemas imersos no contexto da surdez como diferença. Elas demonstram o pertencimento às comunidades surdas, que, insistentemente, lutam pela valorização dos seus aspectos linguísticos e culturais. Lutam por questões em comum, tendo recorrências políticas, culturais e educacionais nas produções literárias, que estão extremamente relacionadas com o contexto histórico que perpassa a contemporaneidade, comprovando a potencialidade do discurso surdo. 
Quando enfatizo a potencialidade do discurso surdo nessas produções literárias surdas, visivelmente notadas pela autorrepresentação, tenciono minha argumentação para a questão de que essas produções, “[...] para que tenham sentidos e significados, precisam ser expressas pelas práticas culturais de significação, pela linguagem, pelos discursos, por aquilo que afirma o que são ou deixam de ser, em que condições, com quais características" (Ratto, 2007, p. 31). Dessa maneira, é importante salientar que em todos os vídeos há o uso da sinalização em primeiro plano, que possibilita a visualização clara e performances em Libras, através do uso de expressões faciais e corporais, movimentos de mão e locações com efeitos estéticos e expressivos que se articulam às possibilidades artístico-literárias de uso da língua de sinais. A sinalização em Libras é, frequentemente, acompanhada de encenações, durante a contação, bem como da utilização de ilustrações, que corroboram a importância da experiência visual surda. $\mathrm{O}$ uso desses recursos visuais favorece o acesso e a construção de sentidos a partir dessas produções.

\section{Narrativas surdas: uma diferença linguística e cultural}

Ao debruçar-me sobre as produções culturais surdas foi possível perceber que as narrativas surdas, de forma geral, mostram a questão da diferença, marca existente, principalmente, no uso da Libras, a língua própria dos surdos. Para compor o estudo desta parte analítica foram selecionados cinco vídeos, os quais, no decorrer da leitura, terão seus títulos citados e suas narrativas contextualizadas.

Como os vídeos que contêm as narrativas surdas estão sendo tratados como artefato cultural, é possível observar “[...] a reivindicação da diferença surda através de práticas discursivas que ensinam um modo surdo de ser, regulando condutas por meio do circuito cultural" (Bortoletti; Müller, 2013, p. 8). Esta afirmação me faz recordar de inúmeras narrativas, entretanto saliento o conto "Peter Pan" (vídeo 1), 
o qual aborda a questão dos surdos usuários da Libras - representados por Peter Pan, Cininho e Capitão Gancho - e dos surdos oralizados - representados pela menina oralizada. Os surdos oralizados são narrados como o grupo que proíbe a língua de sinais, remetendo à história da educação dos surdos: os oralistas opunham-se à linguagem gestual, defendendo a "superioridade" da fala, o que foi oficializado no Congresso de Milão (1880), com a determinação de que todos devem oralizar, pela “[...] pureza 'natural' da palavra falada [...]” (Lulkin, 2010, p. 37). O vídeo mostra que o Capitão Gancho, personagem surdo que usa a língua de sinais, chegou a conviver com os surdos oralizados e, por este motivo, adquiriu um trauma, passando a não admitir surdos assim em suas terras. Este trauma é detalhado por Cininho no seguinte trecho do vídeo 1 (tradução minha):

"Há um tempo atrás, o capitão Gancho viveu com um grupo oralizado e era proibido sinalizar. Ele alegou não saber falar, e o grupo dizia que ele não podia usar sinais. O capitão Gancho desprezou o aviso do grupo e continuou sinalizando. Então, o grupo se uniu e amputou uma de suas mãos.”

Esse trecho mostra representações sobre a oralização, a revolta representada pelo capitão Gancho quanto à imposição da língua oral. Há um repúdio em volta dessa prática fortemente marcada pelo Congresso de Milão e que, ainda hoje, é usada, sendo enfatizada nas narrativas como resistência para a não regressão do que já foi conquistado.

Outro ponto do conto que merece realce é a importância da experimentação do "mundo sinalizado", porque, antes de conhecer Peter Pan, a menina - surda oralizada - vivia com pessoas ouvintes, mas, ao conhecer outros surdos, a língua de sinais e a cultura surda, essa menina assumiu a identidade surda. Como destaca Perlin (2010, p. 52), “A identidade é algo em questão, em construção, uma construção móvel 
que pode frequentemente ser transformada ou estar em movimento, e que empurra o sujeito em diferentes posições". Foi essa transformação que ocorreu com a menina. Como se a interação com outros surdos tivesse "aberto uma passagem" da visão clínica, como alguém que precisava ser corrigida - falar -, para a do reconhecimento de se autoafirmar como surda, usuária da Libras.

Essa importância da convivência com grupos surdos para constituição da identidade surda é reforçada no conto do vídeo 2 "Encontra em cidade puro o surdos" [sic]. É uma história em torno de um surdo que vivia sozinho e triste numa cidade de ouvintes até que resolve entrar em um navio e acaba encontrando uma cidade só de surdos. Nesse enredo, o mesmo surdo é narrado de duas formas: primeiro como sujeito excluído da sociedade, que sofre por não conseguir se comunicar com os ouvintes, como apresentado no trecho a seguir:

"Em 1700 um surdo com idade entre 65 e 66 anos vivia sozinho em uma sociedade em que, no geral, a maioria era ouvinte. Este surdo era pobre, não tinha os pais e, por ser surdo, sofria muito." (trecho do vídeo 2, tradução minha).

Nas palavras de Lopes e Veiga-Neto (2010, p. 120, grifo dos autores):

Na relação com o ouvinte, o surdo foi ensinado a olhar-se e a narrar-se como um deficiente auditivo. A marca da deficiência determinou, durante a história dos surdos e da surdez, a condição de submissão ao normal ouvinte.

Acredito que, na parte inicial, o conto retrata essa marca da submissão, o surdo narrado pelos discursos da deficiência, como alguém indesejado pela falta da audição. Isso inclusive é mostrado mais adiante, quando esse surdo entra em um restaurante e pede um pão, e uma pessoa ouvinte diz: 
"Não, sai! Você não fala, sai!" (trecho do vídeo 2, tradução minha).

Como se essa condição do não ouvir fosse algo contagioso para os que ouvem. A crítica trazida fica ainda mais evidente quando esse personagem, ao subir em um navio, é jogado em alto-mar por ter entrado escondido. Interessante ressaltar que, antes disso, ele enfatiza um dos marcadores culturais surdos, "o olhar", pois diz ao comandante do navio:

"Eu não escuto nada, só vejo." (trecho do vídeo 2, tradução minha).

Assim, ele demarca seu espaço social como um sujeito visual, que “ouve com os olhos". Conforme afirmam Lopes e Veiga-Neto (2010, p. 90, grifo dos autores):

O olhar, para o surdo, muito mais do que um sentido, é uma possibilidade de ser outra coisa e de ocupar outra posição na rede social. [...] Enfim, o olhar como marca é o que permite a construção de uma alteridade surda.

Dessa forma, antes de ser atirado do navio, o surdo afirma aos ouvintes ali presentes sua condição como pessoa culturalmente diferente, deixando de lado, ao menos neste momento, a visão submissa a uma "norma ouvinte".

Ao final dessa história, é enfatizada a questão da alegria sentida por este surdo por estar imerso em um espaço que lhe possibilita se comunicar, que contém uma cultura constituída pela experiência visual, mostrando que a cidade nada mais é do que a comunidade dos surdos, um espaço de resistência, que reforça os modos de ser surdo. Conforme Lopes (2010, p. 113): "Embora existam muitas barreiras sociais, políticas e culturais que dificultam a organização cultural dos 
surdos, estes conseguem resistir às imposições através da sua organização no grupo".

Ao seguir esta linha de representação e afirmação da identidade, língua, cultura e importância do convívio em grupos surdos, percebi, no poema "Menino surdo" (vídeo 3), os movimentos de resistência ao método oralista. Nessa narrativa, percebe-se um jogo com as letras e as cores, indicando três caminhos que o menino pode seguir: a porta $D$ é relacionada ao deficiente auditivo, com o uso do aparelho auditivo; a porta I apresenta um bebê com o implante coclear; enquanto a porta $\mathrm{S}$, com sua cor azul, representa o orgulho surdo, a porta da língua de sinais. É notável a ênfase dada à porta $S$, por ela ser a passagem para o mundo que se comunica pelas mãos. Assim, é transmitido ao "leitor" ${ }^{5}$ que o menino deve constituir-se como surdo, usuário da Libras e pertencente a uma cultura visual, assumindo sua identidade surda e dando valor à língua de sinais.

De acordo com Silveira ${ }^{6}$ (2000, p. 177), quando o surdo é visto com as lentes da perspectiva clínica "[...] definindo-se o surdo como um 'deficiente', o caminho para sua humanização, reabilitação, normalização, enfim, passa pela maximização de seus restos auditivos, pelo treino da leitura labial e pela sua oralização". Essa é a perspectiva presente nas duas primeiras portas, que guardam "recursos" dessas "práticas corretivas", criticadas pelos surdos. Essa forma de "corrigir a audição dos surdos" traz à tona a dominação ouvintista, que segue na tentativa de silenciar suas identidades e apagar sua cultura (Thoma, 2005). Por isso, o poema se mantém posicionando uma possibilidade de escolha, defendida pelo grupo, nos comentários, por ser visível que “[...] o surdo tem posicionamento, língua, cultura” (Bortoletti; Müller, 2013, p. 9).

\footnotetext{
${ }^{5}$ Leitor está entre aspas por ter sido o termo que escolhi para me referir ao público que assistiria a estas narrativas.

${ }^{6}$ Escrita da autora fundamentada em Skliar (1998).
} 
Considerando as lutas e os movimentos de resistência à dominação ouvintista, evidenciados nas narrativas, destaco a fábula "O papagaio e o macaco" (vídeo 4), que apresenta a diferença linguística como uma barreira de comunicação, sem que haja uma tentativa para que ela seja superada. Nessa história é mostrado o olhar de estranhamento do papagaio falante perante o macaco surdo que lhe cumprimenta, tentando iniciar uma conversa. Por usarem línguas diferentes - língua oral e língua de sinais, respectivamente - ambos seguiram por caminhos opostos. Um dos produtores deste vídeo, ao final da fábula, comentou:

"Falta respeito de ambos os lados para conversar". (trecho do vídeo 4, tradução minha).

Esse comentário fez com que refletisse sobre questões trazidas pela visão clínica, sobre a necessidade de oralização e de audição pelo sujeito surdo. Essa benevolência envolve tanto os surdos quanto os demais grupos linguística e culturalmente diferentes, devido às dificuldades criadas pela sociedade. De acordo com Skliar (2003, p. 4): “A questão não é respeitar as diferenças, mas perceber as diferenças como possibilidade. Não há como se despir das diferenças próprias para começar a respeitar outras diferenças”. Dessa forma, a sociedade precisa assumir que há variadas línguas e culturas presentes em nosso país. Essa narrativa e, principalmente, o comentário incluso nela conduzem o "leitor" a pensar que há a necessidade de comunicação entre surdos e ouvintes, então, essas possibilidades de contato e relação não devem ser negadas, por receio de apagamento de uma ou outra cultura; seriam uma maneira de fortalecer e propiciar o conhecimento de outro modo de ser e viver, um banhado pela experiência sonora, e outro, pela experiência visual.

Essa reflexão também é possível por meio do poema "A fase do desenvolvimento do surdo e do ouvinte" (vídeo 5), por apresentar uma comparação das vivências de um surdo e de um ouvinte, demonstrando 
que, nas mesmas fases de crescimento, tanto o surdo quando o ouvinte estão na mesma etapa de aprendizagem, devido a convivências e estímulos eficientes. Isso mostra que, por exemplo, se o ouvinte não estivesse em uma família que o estimulasse e acompanhasse seu desenvolvimento, não teria conseguido alcançar as metas apresentadas no poema. O mesmo se dá em relação ao surdo: se, desde pequeno, não estivesse imerso em uma cultura visual que lhe possibilitasse uma comunicação pelas mãos, não teria chegado aonde chegou. Assim, fica evidente a intenção de realçar que não é por ser surdo que os acontecimentos serão diferentes, mas as escolhas de narrá-lo como um deficiente ou como um sujeito cultural e linguisticamente distinto é que farão a diferença. Desse modo, compreende-se que "[...] toda educação para surdos deveria se afirmar num processo normal de aquisição da língua de sinais. Sem ela não há sujeito e não há diferença e, muito menos, haverá igualdade” (Skliar, 2003).

Por outro lado, essa necessidade de referenciar o ouvinte para narrar-se e se autorrepresentar como um sujeito cultural sob o olhar da diferença é enfatizado por Lopes e Veiga-Neto (2010, p. 123-124), que salientam o quanto este "[...] traço ouvinte presente nas narrativas surdas pode ser interpretado como um elemento estruturador de um tipo de identidade - um tipo de identidade combatente que necessita estar em luta para poder existir e ser reconhecida". Essa narrativa evidencia uma marca cultural da diferença surda, que é de comparação cultural e identitária entre surdos e ouvintes. Mostra, claramente, a importância visual presente nas experiências surdas e a importância sonora nas experiências dos ouvintes, sendo dois elementos diferentes que transformam os modos de ser e viver os mesmos acontecimentos. Como bem destacam Skliar e Quadros (2000, p. 43), os surdos são "pessoas que experienciam o mundo visualmente independente de sons". Entretanto, no comentário referente ao poema, um dos produtores ressalta a 
[...] "Importância da convivência e troca social entre as línguas para aprender e se desenvolver”. (trecho do vídeo 5 , tradução minha).

Com esse comentário, há a possibilidade de relação dos aspectos culturais e linguísticos, até então evidenciados, com as experiências bilíngues que essa diferença lhes proporciona, sendo colocado um "apelo" para que não apenas o surdo tenha que aprender a Língua Portuguesa em sua modalidade escrita para se comunicar com as pessoas ouvintes, mas também que o contrário aconteça para que, efetivamente, ocorram trocas sociais e experimentação de outras línguas e culturas.

\section{Narrativas surdas: contribuições culturais \\ para uma perspectiva de educação bilíngue}

Para compor este capítulo, trato de apontamentos presentes em quatro vídeos que teceram essas análises, possibilitando a construção de uma perspectiva de educação bilíngue. Da mesma forma, faço relações com os estudos analíticos das narrativas citadas anteriormente, destacando alguns trechos que também auxiliam na reflexão de uma perspectiva bilíngue.

As produções culturais surdas abordam, de forma literária, questões referentes às experiências de "ser surdo" e suas lutas, resistências e movimentos para que sua língua, cultura e educação sejam reconhecidas, respeitadas e atendidas. São direitos reivindicados por sujeitos usuários de uma língua oficialmente reconhecida pela Lei $\mathrm{n}^{\circ}$ 10.436/2002. Atualmente, lutam por uma educação bilíngue para surdos que vá além da imersão da língua no espaço educacional, pois:

Estas pessoas consideram-se essencialmente visuais, com uma linguagem visual, uma organização social, uma história e com valores morais que lhes são próprios, 
Com base nas narrativas e argumentações teóricas trazidas neste trabalho, é considerável afirmar que não é possível nomear uma escola de bilíngue quando há, em uma sala de aula, um único aluno surdo, usuário da língua de sinais, que, sem os amparos previstos na Política nacional de Educação Especial na perspectiva da Educação Inclusiva ${ }^{7}$ (2008), é obrigado a oralizar, como mostra o poema "Você precisa ser surdo para entender" (vídeo 6). Essa narrativa apresenta um surdo numa sala de aula com ouvintes. Nesse espaço, ele é obrigado a compreender o que está sendo ensinado sem ter auxílio, seja da professora ou dos colegas, não tendo também o uso da língua de sinais. Suas tentativas de oralizar e tentar compreender, através da leitura labial, foram frustrantes, sendo apontada a exclusão diante das ideias contemporâneas da inclusão. Isso me remete aos modelos educacionais de ensino para os surdos, dentre eles o oralismo, o qual, a partir de uma visão clínica, baseava-se na noção de que a fala era "[...] a única forma desejável de comunicação para o sujeito surdo [...]” (Perlin; Strobel, 2006, p. 12). Para tanto, esse sujeito era, praticamente, obrigado a fazer leitura labial, mais uma vez evidenciando as práticas corretivas. Nesse sentido,

[...] afirma-se que só o surdo consegue entender a dificuldade de estar em uma sala de aula comum, com professores e colegas ouvintes, em situações de não-comunicação, de estar sem acesso à informação, de receber castigo, de sentir-se sozinho e sem companhia, vítima das práticas de oralização ou da benevolência dos ouvintes. (Bortoletti; Müller, 2013, p. 4).

Contudo, o sujeito surdo é narrado como possuidor de uma diferença linguística, confirmando que esses métodos de oralização e práticas

${ }^{7}$ Orientações para o ingresso dos surdos em escolas comuns na página 15 deste documento. (Brasil, 2008). 
corretivas não possibilitam que compreenda o que está sendo dito, pois, como fica claro no depoimento a seguir:

"Como eu sou surdo e sozinho, experimento falar, mas ninguém me ajuda, e fazem conversas paralelas, e eu não consigo entender [...] e é difícil acompanhar". (trecho do vídeo 6 , tradução minha).

O surdo narrado traz à tona sua característica visual, com a qual não consegue acompanhar a discussão em aula. Assim demonstra, ao final desse poema, o alívio que sente por existir a língua de sinais, deixando transparecer que a inserção desses sujeitos visuais em espaços educacionais que menosprezam e não utilizam a língua de sinais ocasiona uma experiência de frustração e sofrimento.

É possível notar a tentativa de mostrar o jeito surdo de ser e os aspectos que uma escola bilíngue deve ter para melhor atendê-los, sendo esta focada, por exemplo, na aceitação da língua de sinais como meio de comunicação e convívio escolar dos surdos. O deslocamento da surdez para o campo da diferença considera que o surdo se constitui através de experiências visuais, tendo uma escola que valorize sua língua e a defenda como necessária para o ensino de qualidade. Essas resistências desprovidas da relação de poder entre a educação colonialista, presente na sociedade brasileira, e os grupos que utilizam outras línguas também ficam evidentes no poema "Bilinguismo junto com Libras" (vídeo 7). Essa narrativa aborda novamente o "apelo" para o reconhecimento da Libras e do bilinguismo. Aponta que é chegado o momento em que os ouvintes também devem se tornar bilíngues, desencadeamento que proporcionaria relações de trocas e convívios sociais, excluindo essa característica educacional e social de apenas os surdos serem obrigados a saber duas línguas, enquanto o 
monolinguismo ${ }^{8}$ ouvinte persiste (Karnopp, 2005). Romper com esse viés "colonialista" é a luta mais recente das comunidades surdas e, por isso, é notável, nessas narrativas, a persistência na defesa pelo reconhecimento de suas características e formas de "ser surdo", construindo uma educação bilíngue que responda a essas reivindicações e assuma uma abordagem com olhar cultural, que valorize as diferenças.

Esses grupos de acadêmicos tencionam escolas bilíngues para surdos, com professores surdos e ouvintes, usuários da Libras, sendo o ensino ministrado na primeira língua, tendo o ensino da leitura, escrita e tradução da língua portuguesa como segunda língua. Essas questões, da importância da docência surda para alunos surdos, estão no poema "O modelo do professor surdo" (vídeo 8). Essa narrativa mostra a surpresa de um professor surdo ao entrar na sala de aula e se deparar com crianças surdas fazendo gestos em vez de sinais. Isso o faz recordar de quando era criança e também usava gestos pela falta de contato com surdos, usuários da Libras. Ou seja, é destacada a pretensão de possibilitar um ensino desde cedo através dessa língua, coibindo repetições dessas histórias de sofrimento e dificuldades de comunicação, que muitos surdos enfrentaram durante as etapas de escolarização. É um poema que traz à tona a necessidade de o professor da comunidade surda - adulto surdo sinalizante - ser uma referência para esses surdos. No texto, identifico duas funcionalidades deste professor surdo: ser modelo - como incentivo para virem a ser futuros professores surdos e ser referência - pelas questões linguísticas e vivências semelhantes, pelos aspectos culturais.

De tal modo, adentro na fábula "Lua, a lobinha surda" (vídeo 9), que traz aspectos referentes à importância da Libras, do ensino bilíngue com convívio e contato entre os surdos, além das trocas entre surdos e ouvintes. O principal destaque nessa narrativa está no surdo como

\footnotetext{
${ }^{8}$ Refiro-me ao monolinguismo oral em relação ao uso da língua de sinais.
} 
alguém diferente e que necessita do contato com outros surdos para aquisição da sua língua e aprendizagem da língua onde vive, como segunda língua. Como é dito, num trecho da história,

"Todos aprenderam facilmente a se comunicarem com Lua, pois dona Águia [...] havia ensinado a língua de comunicação dos surdos, conhecida como a língua de sinais - muito usada na escola em que ela trabalha. Todos os dias a lobinha saía escondida do grande líder e ia para a escola bilíngue onde trabalha dona Águia. Lá aprendia na língua de sinais a língua da floresta, seus coleguinhas eram o elefante Joy, a girafa Pita e o ursinho Duk, também surdos". (trecho do vídeo 9, tradução minha).

Nessa escola, pelo contato com outros surdos e pela aprendizagem da sua língua viso-gestual, Lua, a lobinha surda, passou a constituir sua identidade surda. Nessa narrativa, o "[...] ser surdo pode ser compreendido como a possibilidade de ter uma existência construída sobre marcadores que afirmam a produtividade da diferença, a presença imperiosa do ser sobre si" (Lopes; Veiga-Neto, 2006, p. 91, grifo dos autores).

No desenrolar da história, a lobinha, através das suas características surdas de ser, salva o líder de seu grupo de ser atacado por uma cobra. Dessa forma, sua diferença passou a ser vista como vantagem pelo líder, que decide também aprender a se comunicar por sinais.

Enfim, o ensino, tanto nessa narrativa como nas demais, envolve os marcadores surdos e apresenta "vozes" sinalizadas que desejam cessar as tentativas de fazer o surdo falar, pois eles têm uma língua que deve ser utilizada. As narrativas consideram que os surdos estão em contato constante com duas línguas - Libras e Língua Portuguesa -, apontando para uma educação bilíngue vinculada às relações de trocas entre surdos e entre ouvintes e surdos, promovendo a aquisição dessas 
duas línguas - Libras como primeira língua e Língua Portuguesa como segunda língua, modalidade escrita. Por isso, as reivindicações permanecem principalmente questionando o "[...] quão natural uma língua pode se desenvolver sem que haja trocas entre pares, sem que ela seja vista como uma língua de igual potencial ao da língua portuguesa” (Mourão; Pokorski, 2013, p. 5). Tal excerto pode ser comparado ao poema "Você precisa ser surdo para entender" (vídeo 6), em que o surdo não tinha o contato com o outro, para se constituir como um ser diferente cultural e linguisticamente, sendo, num primeiro momento, apresentado nas características da deficiência, focada na falta da audição como consequência para a incompreensão do que estava sendo ensinado.

Logo, destaco a pedagogia surda que traz a questão da diferença e da defesa cultural "[...] Em que a educação dá-se no momento em que o surdo é colocado em contato com sua diferença para que aconteça a subjetivação e as trocas culturais" (Perlin; Strobel, 2006, p. 19). Esses aspectos dessa pedagogia estão relacionados com os apontamentos para uma educação bilíngue, presentes nessas narrativas, pois, segundo elas, essa educação deve ser construída a partir da perspectiva da surdez como diferença, considerando tanto os aspectos linguísticos quanto culturais, indo ao encontro de Lopes (2007, p. 69), que enfatiza uma proposta educacional de caráter bilíngue:

O caráter bilíngue de uma proposta educativa para surdos deve partir do reconhecimento da diferença cultural dos surdos, bem como do reconhecimento da língua de sinais como sendo própria da comunidade surda à qual o sujeito pertence.

Portanto, essa pedagogia surda bilíngue da diferença considera os aspectos quanto aos modos de ser surdo lançados nas narrativas: a língua, a cultura, a identidade surda e, principalmente, a experiência visual, pois esta constitui a cultura surda, que molda este sujeito. Esses aspectos, presentes nas produções, proporcionaram relações entre 
cultura e educação, pois além de enfatizar "as experiências de ser surdo" também assumem um caráter reivindicatório, modificando, através da literatura, os olhares perante a educação e a cultura surda.

\section{CONSIDERAÇÕES FINAIS}

A partir da investigação de narrativas sobre "ser surdo" e sua relação para a construção da educação bilíngue foi possível notar, nos estudos desdobrados, a evidência das características linguísticas e culturais referentes ao jeito de "ser surdo", guiando-me a pensar sobre a necessidade de uma educação bilíngue baseada na política da diferença. Política essa norteada por uma educação que perpasse as barreiras monolinguísticas, que dominam nossa sociedade, como pude vivenciar na escola para surdos na qual fiz meu estágio. Este ambiente segue a ideia defendida pelos surdos tanto nas narrativas como nos movimentos atuais de reivindicação por uma escola bilíngue, de uso da Libras como língua de instrução e convívio e o ensino da Língua Portuguesa em sua modalidade escrita.

É importante salientar que, no Curso de Letras-Libras - espaço de legitimação da língua, cultura e identidade surda -, a disciplina de Literatura Surda proporcionou a produção de narrativas. As evidências narradas se assemelhavam e se complementavam, demonstrando essa reafirmação em prol do reconhecimento do sujeito surdo, que tem vivências e modos de ser diferenciados da maioria da sociedade. Por isso, a necessidade de considerar, dentre outros aspectos, a identidade surda frente ao ensino de crianças surdas.

\section{REFERÊNCIAS}

BORTOLETTI, P. A.; MÜLLER, J. I. Produções culturais surdas no curso de Letras-Libras. In: 5o SEMINÁRIO BRASILEIRO DE ESTUDOS CULTURAIS E EDUCAÇÃO - 20 SEMINÁRIO INTERNACIONAL DE ESTUDOS CULTURAIS E EDUCAÇÃO: nas contingências do espaço-tempo. Canoas: Ulbra, 2013. CD-ROM. 
BRASIL. Ministério da Educação. Política nacional de educação especial na perspectiva da educação inclusiva. Brasília: MEC/SEESP, 2008. Disponível em: <http://portal.mec.gov.br/seesp/arquivos/pdf/politica.pdf >. Acesso em: 10 abr. 2013.

KARNOPP, L. B. Diálogos traduzidos: leitura e escrita em comunidades de surdos. In: SILVEIRA, R. M. H. (Org.). Cultura, poder e educação: um debate sobre estudos culturais em educação. Canoas: Ulbra, 2005. p. 225-240.

KARNOPP, L. B.; KLEIN, M.; LUNARDI-LAZZARIN, M. (Org.). Cultura surda na contemporaneidade: negociações, intercorrências e provocações. Canoas: Ulbra, 2011.

LANE, H. Representações do surdo: a deficiência e os modelos culturais. In: A máscara da benevolência: a comunidade surda amordaçada. Lisboa: Instituto Piaget, 1992. Coleção: Horizontes Pedagógicos. Tradução: Cristina Reis. p. 19-41.

LOPES, M. C. Surdez e educação. Belo Horizonte: Autêntica, 2007. . Relações de poderes no espaço multicultural da escola para surdos. In: SKLIAR, C. (Org.). A surdez: um olhar sobre a diferença. 4. ed. Porto Alegre: Mediação, 2010. p. 103-118.

LOPES, M. C.; VEIGA-NETO, A. Marcadores culturais surdos: quando eles se constituem no espaço escolar. Perspectiva: Revista do Centro de Ciências da Educação, Florianópolis, v. 24, número especial, p. 81-100, jul./dez. 2006. Disponível em: <http://www.perspectiva.ufsc.br>. Acesso em: 10 maio 2013. . Marcadores culturais surdos. In: VIEIRA-MACHADO, L. M.; LOPES, M. C. (Org.). Educação de surdos: políticas, língua de sinais, comunidade e cultura surda. Santa Cruz do Sul: EDUNISC, 2010. p. 116-137.

LULKIN, S. O discurso moderno na educação dos surdos: práticas de controle do corpo e a expressão cultural amordaçada. In: SKLIAR, C. (Org.). A surdez: um olhar sobre a diferença. 4. ed. Porto Alegre: Mediação, 2010. p. 33-49. 
MOURÃO, C. H. N.; POKORSKI, J. O. Arte surda: produto e produtora do movimento de resistência política dos surdos. In: 5० SEMINÁRIO BRASILEIRO DE ESTUDOS CULTURAIS E EDUCAÇÃO - $2^{\circ}$ SEMINÁRIO INTERNACIONAL DE ESTUDOS CULTURAIS E EDUCAÇÃO: nas contingências do espaço-tempo. Canoas: Ulbra, 2013. CD-ROM.

PERLIN, G. T. O lugar da cultura surda. In: THOMA, A. S.; LOPES, M. C. (Org.). A invenção da surdez: cultura, alteridade, identidade e diferença no campo da educação. Santa Cruz do Sul: EDUNISC, 2004. p. 73-82.

. Identidades surdas. In: SKLIAR, C. (Org.). A surdez: um olhar sobre a diferença. 4. ed. Porto Alegre: mediação, 2010. p. 51-73.

PERLIN, G. T.; MIRANDA, W. Tendências - surdos: o narrar e a política. Ponto de Vista: Revista de Educação e Processos Inclusivos, Florianópolis, n. 5, p. 217-226, 2003.

PERLIN, G. T.; STROBEL, K. Modelos educacionais na educação de surdos. In: . Fundamentos da educação de surdos. 2006. Disponível em: <http://www.libras.ufsc.br/hiperlab/avalibras/moodle/prelogin/adl/fb/ logs/Arquivos/textos/fundamentos/Fundamentos_da_Educ_Surdos.pdf $>$. Acesso em: 20 maio 2013.

QUADROS, R. M.; KARNOPP, L. B. Lingua de sinais brasileira: estudos linguísticos. Porto Alegre: Artmed, 2004.

RATTO, A. L. S. Livros de ocorrência: (in)disciplina, normalização e subjetivação. São Paulo: Cortez, 2007.

SÁ, N. R. L. Cultura, poder e educação de surdos. São Paulo: Paulinas, 2002.

SILVEIRA, R. H. Contando histórias sobre surdos(as) e surdez. In: COSTA. M. (Org.). Estudos culturais em educação. 2. ed. Porto Alegre: Editora UFRGS, 2000. p. 175-204.

Discurso, escola e cultura: breve roteiro para pensar narrativas que circundam e constituem a educação. In: . Cultura, poder e educação: um debate sobre estudos culturais em educação. Canoas: Ulbra, 2005. p. 197-209. 
SKLIAR, C. Diferenças: as armadilhas de um sistema de exclusão. Entrevista concedida. Folha dirigida, [s.l.], 2003.

SKLIAR, C. (Org.). A surdez: um olhar sobre as diferenças. Porto Alegre: Mediação, 1998.

4. ed. Porto Alegre: Mediação, 2010.

SKLIAR, C.; QUADROS, R. Invertendo epistemologicamente o problema da inclusão: os ouvintes no mundo dos surdos. Estilos da Clínica: Revista do Instituto de Psicologia da USP, São Paulo, v. 5, n. 9, p. 32-51, 2000.

THOMA, A. S. A inversão epistemológica da anormalidade surda na pedagogia do cinema. In: THOMA, A. S.; LOPES, M. C. (Org.). A invenção da surdez: cultura, alteridade, identidade e diferença no campo da educação. Santa Cruz do Sul: EDUNISC, 2004. p. 56-69. 


\title{
Sentidos da escola para os jovens $e$ adultos surdos
}

simone de Brum

\begin{abstract}
"Uma língua só pode ser utilizada em contato com outros sujeitos, portanto, em comunidade. Em comunidade, valores e experiências são compartilhados e vão engendrando modos de ser e estar no mundo, e esses valores e experiências constituem aquilo que chamamos de cultura."

Adriana da Silva Thoma
\end{abstract}

Este artigo problematiza alguns sentidos da escola para determinados jovens e adultos surdos, na perspectiva da cultura e comunidade surda. Realizei entrevistas semiestruturadas com três alunos surdos de turmas de educação de jovens e adultos (EJA), de uma escola pública municipal de Porto Alegre, e, por fim, analisei as respostas obtidas, com o intuito de compreender o que buscam esses alunos ao frequentarem a escola. Partindo de algumas problemáticas percebidas no decorrer desse trabalho, realizei a análise das entrevistas, agrupei-as por sentidos/ respostas similares e, então, interpretei-as com embasamento teórico, utilizando as ideias de Zigmunt Bauman (2003) para sustentar a compreensão adotada sobre o conceito de comunidade ao escrever que "A 
'comunidade', cujos usos principais são confirmar, pelo poder do número, a propriedade da escolha e emprestar parte de sua gravidade à identidade a que confere 'aprovação social', deve possuir os mesmos traços" (p. 62). Além disso, baseei-me em pesquisadores do campo dos Estudos Surdos, como Adriana da Silva Thoma (2011), Maura Corcini Lopes (2007) e Liliane Ferrari Giordani (2003) em relação aos conceitos de "comunidade" e "cultura surda".

Conforme realizava leituras acerca da temática, ia percebendo o quanto os conceitos comunidade e cultura surda são importantes na constituição do sujeito surdo. Giordani (2003, p. 18) explica que

O conceito de cultura que marca a escolha do referencial (Hall, 1997a; 1997b; 1999) ${ }^{1}$ fundamenta-se no entendimento de cultura como um processo, um conjunto de práticas com a produção e o intercâmbio de significados entre os membros de um grupo e, para este trabalho, o grupo é representado pela comunidade surda. Neste sentido, compreende-se os significados culturais como organizadores e reguladores das práticas sociais, influenciando nossas condutas e consequentemente tendo efeitos práticos no cotidiano.

A condição de jovens ou adultos retomando os estudos já mostra que um dia eles tiveram que deixar de estudar por algum motivo, seja por ciúmes do cônjuge, por ter que cuidar da casa, por ter que trabalhar para ajudar ou sustentar a família. Enfim, tantas são as histórias que escutei que esta retomada me pareceu, em muitos momentos, uma luta muito grande para poderem estar na escola novamente. Jovens e adultos que vêm fazer neste espaço mais uma tentativa, entre tantas

${ }^{1}$ Hall, Stuart. A centralidade da cultura: notas sobre as revoluções culturais do nosso tempo. Educação e Realidade, Porto Alegre, v. 22, n. 2, p. 15-46, 1997a.

. The work of representation. In: (Org.). Representation: cultu-

ral representations and signifying practices. London, Sage, 1997b. . A identidade cultural na pós-modernidade. Rio de Janeiro: DP\&A, 1999. 
já experimentadas, de viver, em um lugar, sua própria língua, a cultura de sua comunidade, e que acreditam que, talvez, desta vez seja possível (Giordani, 2003, p. 21).

Existe um sentimento de proteção e acolhimento que muitas vezes estes alunos não percebem fora do espaço escolar. Percebi que os sujeitos surdos sentem falta da relação com outros surdos. Lopes (2007, p. 10) relata:

Sigo a escrita buscando referenciais que me possibilitem narrar os surdos como sujeitos culturais que, por não nascerem territorialmente próximos (Wrigley, 1996), necessitam ser aproximados uns dos outros. Tal aproximação tem se dado, geralmente, nas escolas e, mais recentemente, nas associações de surdos.

Isso nos faz perceber o quão importante é a educação de jovens e adultos surdos, pois é na escola que aprendem, trocam experiências, ajudam os colegas, vivem em comunidade e se identificam com a cultura surda, criando suas próprias identidades de sujeitos surdos.

Difícil definir a cultura ou comunidade surda, pois não é única, ou seria possível definir a cultura ou comunidade ouvinte? Comunidade surda e cultura surda andam juntas, uma completa a outra, e são fundamentais para os jovens e adultos surdos que buscam na escola a troca de experiências, vivências, costumes e, principalmente, língua. Giordani (2003, p. 49) afirma:

Para que se torne possível partilhar códigos culturais, é preciso que os membros de um grupo, de uma comunidade venham a partilhar conceitos, imagens, ideias, possibilitando que pensem e sintam o mundo, interpretando-o de maneira mais ou menos parecida. Neste sentido, pensar e sentir constituem sistemas de representação e, para que se possa comunicar estes significados a outras pessoas, é preciso compartilhar 
de um mesmo código linguístico. Na escola de educação de surdos, assim como nas escolas que atendem classes populares, meninos e meninas em situação de rua, jovens e adultos com histórico de marginalização social, observa-se um deslocamento entre o texto do professor e as histórias de vida de seus alunos.

O sentimento de pertencer a um grupo de semelhantes nos tranquiliza, faz com que nos sintamos parte de algo; é um lugar de onde não somos excluídos, pois formamos uma comunidade e temos cultura própria. Analisando as falas dos entrevistados, tentei compreender os sentidos da escola para estes alunos sem esquecer a importância substantiva desse sentimento, desse pertencimento, interpretando as longas conversas que foram transcritas e categorizando-as conforme apresento a seguir.

\section{TROCANDO EXPERIÊNCIAS $\varepsilon$ VIVÊNCIAS}

Os sentidos da escola, para os entrevistados, apontam a busca de seus semelhantes, querendo participar, aprender a ler, escrever, sinalizar. Esta foi a característica com maior incidência: os surdos compreendem a escola como espaço de convivência, de ter com quem compartilhar as experiências de vida e, principalmente, de conhecer outros surdos. Ângela ${ }^{2}$ deixa isso claro ao ser questionada em relação às mudanças observadas em sua vida ao retornar para a escola:

Agora a minha vida tá boa, porque antes era eu e a Catarina (colega) e mais um outro menino, um outro amigo surdo, só nós três, e eu quero conhecer mais, né, mas tem que ter paciência, tem que estudar bastante; antes, lá no centro em que eu estudava, tinha muitas pessoas, uma sala grande, agora é uma sala pequena, são poucos alunos, são só três.

${ }^{2}$ Os nomes serão fictícios para preservar a identidade dos entrevistados. 
Ser surdo exclui estes alunos de uma suposta normalidade com que estamos acostumados a conviver, e, tendo em vista que a comunidade ouvinte é grande maioria, pensa-se que ser diferente os torna menos capazes de algo.

No decorrer das entrevistas, percebi que a evasão escolar destes alunos em momentos anteriores de suas vidas tem relação com o tipo de ensino que recebiam: eles eram ensinados da mesma forma que os ouvintes e sofriam com isso, pois não escutavam as professoras e, como consequência, não aprendiam. Catarina esclarece minha percepção ao dizer que:

...quando eu era pequena, nunca estudei com surdos... minha mãe nunca me colocou em uma escola de surdos... e a professora falava, e eu surda não entendia nada, eu só copiava, não entendia nada. Agora, depois que eu cresci, quando era nova, parei de estudar, e agora, eu já com idade avançada voltei a estudar. Eu vi que tem bastantes surdos, crianças surdas, e eu vejo, ai que lindo! Aí eu me lembro que a minha mãe nunca me colocou em uma escola, e eu queria muito antigamente ir a uma escola de surdos que nem os pequenos que eu vejo, pra aprender, pra ver, e eu me lembro isso quando eu vejo, né, e a minha mãe nunca me ajudou nisso.

Os três alunos entrevistados estudaram em escolas de ouvintes na sua infância. A fala da Catarina reforça ainda mais minha ideia de que isto foi causa de grande desestímulo, comprometendo a sua permanência na escola.

\section{DIA A DIA \& O FUTURO}

O futuro é outro sentido comum ao público da EJA. Embora encontrado em menor incidência nas respostas obtidas, se comparado com o sentido anterior, ele é significativo, pois remete às práticas adotadas pelos professores destes alunos em sala de aula. Ângela fala sobre isso: 
Tem que estudar, pra crescer, aprender, é muito bom, precisa. Sempre aprender mais. Daí eu vou aprendendo matemática, pra mexer com dinheiro, porque eu não sei muito, matemática eu não sei muito, então precisa... Pro futuro, pra eu ir pra quarta série eu preciso aprender, não posso ter preguiça... eu tenho que participar, vir sempre nas aulas e estudar bastante, toda semana.

Nos relatos, percebi grande dificuldade de locomoção dos alunos pela cidade de Porto Alegre. Eles tiveram que decorar o nome do ônibus que pegam para ir até a escola, ou até outro local, pois não sabem ler. Foi necessário aprender e encontrar uma forma diferente de identificar o transporte.

\section{OUTRAS PERCEPÇÕES}

Por fim, um agrupamento que abrange diversos sentidos, pois foram percebidos com menor frequência. Como é o caso do Bento, que, em muitas respostas, cita a alimentação disponível na escola:

Lá na outra escola não era muito bom, aqui a comida é melhor, o arroz é bom, eu gosto daqui, aqui é muito bom, eu como tudo aqui, o leite é muito bom, o leite... a banana eu não gosto, mas tem que estudar sempre, é bom estudar.

A impressão que tive em relação à insistência desse assunto, em suas respostas, é que ele pode ter passado por dificuldades financeiras, tendo como consequência a falta de comida em casa. Perguntei a ele o que o fazia ir à escola, e ele respondeu: 
"De noite às 6 horas, daí eu venho aqui e como, descanso um pouco e sinalizo um pouco."

Isso reafirma o meu pensamento.

Outra característica que me chamou muito a atenção foi a declaração da Ângela quando explicita:

"Eu queria ouvir, eu queria falar, eu não gosto, mas com aparelho eu consigo falar um pouco, eu queria falar. Mas eu não ouço, eu queria ouvir, quando batessem palma, quando abrissem a porta, quando me chamassem e eu estivesse dormindo. A minha filha vem no quarto e diz: 'tu não ouviu eu te chamar?' E eu digo, 'Desculpa, eu não ouvi'. E ela diz: 'É verdade?' Mas eu tô sem aparelho, mas eu sou surda, e ela ouve bem."

Mesmo que o meu trabalho seja com ênfase na cultura e comunidade surda e na importância destes conceitos para a educação de jovens e adultos surdos, acredito que seja relevante apresentar esta fala, que me demonstrou um incômodo em ser surda. Mas essa aluna também, e ao mesmo tempo, mostra interesse na troca de experiências e convivência com os demais colegas surdos ao relatar que retomou os estudos:

"Pra me estimular, pra aprender, pra ter educação, pra aprender bastante, eu preciso, isso é bom, pro meu futuro também, pra ir pra terceira série. Antes eu parei e eu não estudei nada, há muito tempo atrás, há muito tempo atrás, daí eu tive 3 filhos, nasceu os filhos, eu sofri muito, tinha fome, me separei, me ajudavam, diziam vai pra escola estudar; daí eu fui pra escola, e agora vim para esta escola. 
E tá bom. Eu tenho que ser esforçada, não tenho que ter preguiça, eu tenho que abrir o conhecimento, tenho que ficar feliz, estudar bastante. Eu gosto de vir, de passear pra vir pra aula, eu gosto muito, gosto de aprender e estudar, matemática é difícil, mas no meu futuro, pra ir pra quarta série, daí precisa também.”

É possível que outros sentidos tenham passado despercebidos pela minha leitura e análise. Mas acredito que as características mais significativas tenham sido vistas, questionadas e teorizadas dentro das minhas possibilidades.

\section{CONCLUSÕES}

Os sentidos da escola para os entrevistados apontam para a busca de seus semelhantes, querendo participar e aprender a ler, escrever, sinalizar. Concluo, então, que o sentido principal do retorno à escola se refere ao compartilhamento da cultura surda, embora outros sentidos comuns ao público da EJA também tenham sido identificados.

A compreensão do sentido que a escola tem para estes alunos pode ajudar a entender a importância da comunidade e da cultura para os sujeitos surdos. Acredito que esse entendimento pode auxiliar no desenvolvimento de práticas significativas para esses sujeitos. Por isso penso que é nas escolas que as lutas dos movimentos surdos devem iniciar, é nelas que nós, como docentes, devemos incentivar e estimular a comunidade surda a lutar pelos seus direitos. Perlin (2004, p. 79) esclarece que

Para o surdo, não é "tudo é cultura", mas o que tem significado essencial para a constituição da existência tem a sua dimensão cultural, um significado, uma política. Isso porque a cultura é uma parte constitutiva do político, que, por sua vez, impõe os limites culturais. 
Existe a necessidade da troca, do compartilhamento de ideias e pensamentos, da convivência com os iguais, de sentir-se parte de uma comunidade onde as pessoas ao seu redor tenham características semelhantes às suas. Isso tudo facilita a aprendizagem, a vontade de frequentar a escola.

\section{REFEREิNCIAS}

BAUMAN, Z. Comunidade: a busca por segurança no mundo atual. Rio de Janeiro: Jorge Zahar Editor, 2003.

GIORDANI, L. F. “Quero escrever o que está escrito nas ruas”: representações culturais da escrita de jovens e adultos surdos. Tese de Doutorado Faculdade de Educação, Universidade Federal do Rio Grande do Sul, Porto Alegre, 2003.

LOPES, M. C. Surdez e educação. Belo Horizonte: Autêntica, 2007.

PERLIN, G. O lugar da cultura surda. In: THOMA, A. S.; LOPES, M. C. (Org.). A invenção da surdez: cultura, alteridade, identidade e diferença no campo da educação de surdos. Santa Cruz do Sul: UNISC, 2004.

THOMA, A. S. Representações sobre os surdos, comunidades, cultura e movimento surdo. In: Lopes, M. C. (Org.). Cultura surda e libras. São Leopoldo: Editora Unisinos, 2012, p. 87-100.

. Educação bilíngue para surdos no contexto da educação inclusiva. In: MORAES, S. C. de (Org.). Educação inclusiva: diferentes significados. Porto Alegre: Editora Evangraf, 2011. p. 129-139. 
PARTE 2

PROPOSTAS CURRICULARES EM FOCO 


\section{Práticas avaliativas e progressão continuada na rede municipal de Eldorado do sul/RS:}

a ênfase está nas aprendizagens dos alunos?

Juliana Hass Massena

Este capítulo apresenta análises e considerações produzidas em estudo referente ao nexo entre progressão continuada-aprendizagempráticas avaliativas nos anos iniciais do ensino fundamental nas escolas da rede municipal de Eldorado do Sul (Rio Grande do Sul), tendo como base a orientação do Ministério da Educação quanto à não retenção das crianças no primeiro ciclo do ensino fundamental e a adesão do município ao Pacto Nacional pela Alfabetização na Idade Certa (PNAIC) ${ }^{1}$. Tal exercício de pesquisa justifica-se pela necessidade

\footnotetext{
${ }^{1}$ O Pacto Nacional pela Alfabetização na Idade Certa (PNAIC) é um compromisso formal assumido pelos governos federal, do Distrito Federal, dos estados e municípios de assegurar que todas as crianças estejam alfabetizadas até os 8 anos de idade, ao final do $3^{\circ}$ ano do ensino fundamental. Ao aderir ao Pacto, os entes governamentais se comprometem a: alfabetizar todas as crianças em língua portuguesa e em matemática; realizar avaliações anuais universais, aplicadas pelo INEP, junto aos concluintes do $3^{\circ}$ ano do ensino fundamental; no caso dos estados, apoiar os municípios que tenham aderido às Ações do Pacto, para sua efetiva implementação. (Portaria no 867, de 4 de julho de 2012).
} 
de nós, professores da rede municipal de Eldorado do Sul, irmos a campo e discutirmos criticamente as possibilidades, os limites e os desafios institucionais nos processos de gestão escolar. Cabe mencionar que obtive autorização da Secretaria Municipal de Educação de Eldorado do Sul para realizar esta pesquisa, dando publicidade aos meus achados.

A escolha desse tema de pesquisa foi sendo constituída com a minha trajetória profissional docente. Em 2008 fui nomeada professora de séries iniciais no município de Eldorado do Sul, e, desde a minha inserção na rede municipal de ensino da cidade, muitos questionamentos estiveram presentes, fazendo com que o meu olhar se desacomodasse, transformando-se em um olhar pesquisador e, como tal, atento, observador, curioso, problematizador. Ao me deparar com a proposta de progressão continuada da rede municipal de Eldorado do Sul, implementada no município em 2006, desenvolvi um interesse em melhor estudá-la em seus efeitos sobre as aprendizagens dos alunos. Nesse sentido, acredito na importância desse estudo, com a clareza de que a prática da progressão continuada envolve uma mudança na concepção de ensino, aprendizagem e avaliação, pois penso que respeitar os ritmos individuais de aprendizagem de cada aluno, garantir uma vida escolar de sucessos e formar um cidadão consciente e confiante em sua capacidade são os principais objetivos dessa proposta.

Todavia não posso negligenciar que o princípio da não retenção, no âmbito da rede pesquisada, não consegue desfazer, por si mesmo, os nós imbricados no sistema de ensino e reverter o quadro de exclusão que ainda persiste. Os professores, os pais e mesmo os alunos têm questionado o fato de os alunos estarem passando de ano sem os conhecimentos e competências exigidos pela sociedade contemporânea. Assim, aqueles que anteriormente eram excluídos por não terem acesso ou possibilidades de permanência na escola seriam excluídos hoje pelo não domínio das competências escolares. 
Ao considerar essas razões para o estudo, estabeleci os seguintes objetivos: analisar as concepções dos professores da rede municipal de Eldorado do Sul sobre o papel e as finalidades dos anos iniciais do ensino fundamental na sociedade brasileira contemporânea e o significado do processo de aprendizagem de seus alunos para traçar um panorama significativo sobre como as práticas de avaliação vêm sendo desenvolvidas.

A ideia de progressão continuada insere-se numa perspectiva de educação escolar voltada para a formação humana. Ao pretender a realização da educação para todos, a escola deve buscar formas de superar os mecanismos políticos e pedagógicos que contribuem para perpetuar a exclusão. Argumentos como "os alunos não querem aprender", "não têm vontade", "não se dedicam", "não têm capacidade", "não têm apoio da família", "só querem saber de brincar e conversar", muitas vezes usados para justificar a pouca aprendizagem dos alunos e legitimar a reprovação, precisam ser ressignificados na perspectiva da educação como direito. De acordo com Perrenoud (2004, p. 13), a diferenciação passa a incidir "[...] sobre o modo e a intensidade do acompanhamento pedagógico, o que leva a uma diversificação dos percursos de formação". Dessa forma, embora o tempo para realizar a educação obrigatória seja igual para todos, os percursos podem ser diferentes.

\section{PROCEDIMENTOS METODOLÓGICOS DO ESTUDO}

Minha pesquisa configura-se como uma pesquisa qualitativa, visto que foi pensada e realizada na perspectiva do exercício pedagógico, buscando contribuir para a qualificação das práticas avaliativas no cotidiano das escolas do município de Eldorado do Sul. Ainda, minha escolha contempla o estudo de caso de cunho etnográfico. Segundo Menga Lüdke e Marli E. D. A. André (1986), entre as características do estudo de caso, destacam-se: a descoberta; a "interpretação em contexto"; uma variedade de fontes de informação; experiência vicária; diferentes e às vezes conflitantes pontos de vista; uma linguagem e 
uma forma mais acessível do que outros relatórios de pesquisa. Lüdke e André (1986) ressaltam, também, que a etnografia como "ciência da descrição cultural" envolve pressupostos específicos sobre a realidade e formas particulares de coleta e apresentação. Todavia utilizei ferramentas etnográficas, combinando técnicas de observação, entrevistas e análise de documentos.

Realizei, inicialmente, rastreamento (em repositórios digitais) dos trabalhos publicados acerca da temática por mim escolhida. Na sequência, imersa na revisão de literatura, identifiquei pontos de convergência nas obras de Vasconcellos (2003), Perrenoud (1999 e 2004) e Hoffmann (1991, 1993, 2001 e 2007). Tais autores me permitiram pensar sobre o processo de avaliação e estabelecer relações significativas com os achados da minha pesquisa.

Ressalto a importância do uso da entrevista nesta pesquisa, tendo em vista que as pessoas se motivam mais para falar do que para escrever, constituindo-se, também, numa forma de interação entre pesquisado e pesquisador. Optei pela entrevista semiestruturada, ${ }^{2}$ com perguntas previamente determinadas. No entanto, quando necessário (dependendo das respostas dos entrevistados), acrescentei questões não previstas que

${ }^{2}$ Roteiro das entrevistas: Qual é a tua formação?; Há quanto tempo trabalhas na rede municipal de Eldorado do Sul?; Com quais classes/níveis de ensino atuaste ou estás atuando (ano 2013)?; No teu entender, como uma professora pode perceber indícios de aprendizagem dos alunos?; Tu te apoias em algum referencial específico para essas práticas? Quais? Por que essa escolha?; Utilizas estratégias diferenciadas para possibilitar os avanços dos alunos? Quais?; No teu entender, as tuas práticas avaliativas têm contribuído para a construção da autonomia dos alunos? Justifica tua resposta.; O que entendes por progressão continuada? Pra ti, há diferença entre progressão continuada e aprovação automática? No teu entender, qual o objetivo desta proposta (progressão automática)?; As professoras da rede municipal receberam orientações para a implementação da progressão continuada nos anos iniciais? Se afirmativa a resposta: Quais e como foram dadas as orientações? Se negativa a resposta: Como te sentiste como professora da rede sem as orientações? Na ocasião, como atuaste para dar conta dessa implementação?; Qual tua opinião sobre a proposta de progressão continuada? E sobre a não 
buscaram garantir a fluidez do diálogo e o rigor quanto ao problema de pesquisa. Realizei entrevistas individuais com cinco professoras da rede municipal de Eldorado do Sul, três delas dos anos iniciais e duas dos anos finais do ensino fundamental. É importante destacar que as professoras convidadas a participar da pesquisa assinaram Termo de Consentimento Informado, estando suas identidades preservadas.

P1 ${ }^{3}$ cursou Magistério, é graduada em Pedagogia com habilitação para Anos Iniciais e especialista em Alfabetização, atua na rede há sete anos com turmas do ciclo de alfabetização. P2 cursou Magistério, é graduada em Pedagogia com ênfase em Orientação e Supervisão Escolar e especialista em Psicopedagogia, trabalha na rede há 22 anos e em 2013 é titular de turmas de $4^{\circ}$ e $5^{\circ}$ ano. P3 é graduada em Pedagogia e atua na rede há dois anos, é titular de uma turma de $1^{\circ}$ ano. P4 possui Licenciatura Plena em Biologia, trabalha na rede há sete anos com turmas de $6^{\circ}$ ano à $8^{\text {a }}$ série. P5 cursou Magistério e possui Licenciatura Plena em Matemática, é docente da rede há 22 anos, já foi diretora de escola e trabalha com turmas dos anos finais do ensino fundamental e, no turno da tarde, no laboratório de aprendizagem.

A escolha das professoras entrevistadas obedeceu aos seguintes critérios: ser professora efetiva na referida rede pelo tempo mínimo de um ano; ter trabalhado em, no mínimo, duas escolas da rede. Após a realização das entrevistas, fiz a transcrição dos arquivos de áudio para analisar as informações obtidas e organizá-las em categorias.

\footnotetext{
${ }^{2}$ retenção nos anos iniciais?; No teu entender, a não retenção nos anos iniciais é um procedimento que favorece os processos de aprendizagem dos alunos? Justifica tua resposta.; Na tua opinião, o planejamento das professoras dos anos iniciais e suas práticas avaliativas, na proposta de progressão continuada, estão voltados para as necessidades dos alunos? Justifica tua resposta.; Qual tua opinião sobre as possíveis relações entre progressão continuada e o aproveitamento dos alunos?

${ }^{3}$ As entrevistadas são denominadas, neste trabalho, com a seguinte convenção: P1, P2, P3, P4 e P5.
} 
Nesta pesquisa utilizei, também, documentos orientadores e normativos emitidos pelo Conselho Nacional de Educação, Conselho Estadual de Educação e Conselho Municipal de Educação, bem como legislação educacional vigente em âmbito nacional. Para a análise de tais documentos, elaborei um quadro-roteiro que me ajudou a localizar informações relevantes em meio ao conjunto extenso e amplo de informações. A partir da leitura e tabulação dos dados, foi possível construir uma síntese dos textos dos documentos, contemplando as práticas avaliativas e a progressão continuada.

No decorrer da investigação, mediante a realização das entrevistas, e das análises dos documentos, em constante diálogo com os autores que constituíram o aporte teórico deste trabalho, dediquei-me à busca de respostas, ainda que provisórias, para as questões orientadoras do estudo e problema de pesquisa.

\section{GESTÃO DA APRENDIZAGEM: AVALIAR PARA ENSINAR MELHOR}

Entendo que a ênfase do trabalho pedagógico está no aprender, assim, acredito que se torna indispensável uma mudança em quase todos os níveis educacionais: currículo, gestão escolar, organização da sala de aula, tipos de atividade e formas de avaliar. Nesse sentido, a avaliação formativa prevê que os estudantes possuam ritmos e processos de aprendizagem diferentes. Para Hoffmann (1991), a ação avaliativa, enquanto uma das mediações pela qual se encorajaria a reorganização do saber, implica ação, movimento, provocação, na tentativa de reciprocidade intelectual entre os elementos da ação educativa. Professor e aluno buscam coordenar seus pontos de vista, trocando ideias, reorganizando-as.

\section{Ciclos de Aprendizagem}

No campo pedagógico, Perrenoud é um dos principais autores que tem fundamentado os Ciclos de Aprendizagem nos países europeus e 
no Brasil. Segundo Perrenoud (2004), a organização da escolaridade em Ciclos de Aprendizagem é uma alternativa para enfrentar o fracasso escolar que garantiria a aprendizagem dos alunos, por meio da progressão das suas aprendizagens. Dessa forma, a implantação de Ciclos de Aprendizagem em uma rede de ensino constitui-se em uma oportunidade de construir um novo tipo de escola, baseada na lógica da aprendizagem e não na mera classificação e reprovação de alunos. $\mathrm{O}$ autor apresenta aspectos necessários a essa implantação:

a) implica mudanças na organização e gestão da escola; b) exige que os objetivos de final de ciclo sejam claramente definidos para professores e alunos; c) pressupõe o emprego de dispositivos da pedagogia diferenciada, da avaliação formativa e o trabalho coletivo de professores; d) demanda uma formação contínua dos professores, o apoio institucional e o acompanhamento adequado "para construir novas competências". (Perrenoud, 2004, p. 52).

Os ciclos de formação e outras formas de regimes ciclados enfrentam muitas resistências de professores para aceitar e efetivar a mudança, pois o regime anterior, com testes finais e apresentação de resultados burocráticos, permeia o dia a dia da escola. Outra dificuldade que as escolas enfrentam é a efetivação de um trabalho pedagógico que dê conta das diferenças dos alunos, pois os professores continuam a desenvolver as mesmas práticas do regime seriado, presos a currículos, não sabendo como lidar com os alunos que não acompanham suas propostas ou o ritmo da maioria.

Desde a década de 1960, a grande crítica são os estragos da prática classificatória e excludente: os elevadíssimos índices de reprovação e evasão, aliados a um baixíssimo nível da qualidade da educação escolar, em termos de apropriação do conhecimento ou de formação de uma cidadania ativa e crítica. Nos anos 2000, a avaliação está também em pauta como decorrência das várias iniciativas tomadas 
por mantenedoras, públicas ou privadas, no sentido de reverter este quadro de fracasso escolar.

Segundo Vasconcellos (2003), avaliar aprendizagens é um sério problema educacional há muito tempo. De acordo com o autor, a prática de avaliar pode ser dividida em quatro categorias: conteúdo, forma de avaliar, relações que a avaliação estabelece na prática de ensino e intencionalidade. Para ele, a mais importante é a intencionalidade: mudanças nos outros aspectos sem mudar a intenção com a qual se avalia não se efetivam.

Acredito que é preciso recuperar o direito ao conhecimento como eixo estruturante do currículo e da docência, reorientando os processos e critérios de avaliação, o que implica, necessariamente, reorientar a organização curricular.

\section{PROGRESSÃO CONTINUADA}

Durante longos anos no Brasil, o direito à educação significou, restritamente, matrícula para ingresso em alguma escola. A partir da Constituição Federal de 1988, paulatinamente, o significado do direito à educação se amplia ao dar ênfase ao aprendizado. A escola brasileira organizada inicialmente para educar e formar a elite nacional -, desde a Lei de Diretrizes e Bases da Educação Nacional (LDBEN) n 9394/96, vem ampliando o atendimento à população. Entretanto, ainda não foi realizada a construção de um sistema de ensino cuja finalidade proclamada é garantir a apropriação da cultura às novas gerações. Mesmo com os avanços quanto à democratização do acesso à escola, a organização do processo de ensino-aprendizagem vem mantendo características da escola tradicional seletiva. Entre elas, pode-se destacar a distribuição dos conteúdos por anos e a utilização de metodologias, tempos e avaliações uniformes.

Em certo sentido, a diversificação dos modos e dos tempos de aprendizagem, característica dos demais espaços sociais, foi substituída na 
escola por tempos e conteúdos preestabelecidos para cada faixa etária de acordo com padrões historicamente determinados. Assim, todos os elementos que compõem a atividade educativa escolar são pensados e organizados em função da média de um quantum que se pode aprender numa determinada idade que corresponde a um ano escolar.

Essa forma de organizar o ensino produziu um grave problema às instituições escolares: o que fazer com os alunos - em maior ou menor número, de acordo com o contexto histórico-social - que não têm desempenho escolar adequado? A solução historicamente legitimada pela escola foi a reprovação. A reprovação tende a responsabilizar de forma unilateral os alunos e os pais, especialmente os das classes populares, pelo desempenho escolar, transformando um problema que é social e educacional em questões individuais vinculadas à capacidade ou ao empenho de cada um.

Diante das dificuldades da instituição escolar e dos professores em mobilizarem nos alunos o desejo e os recursos necessários à aprendizagem, a ameaça da reprovação passou a ser o principal instrumento de pressão para garantir disciplina, realização de tarefas e estudos, principalmente em épocas de provas, ou seja, uma forma de submissão dos alunos a uma organização escolar incapaz ou impossibilitada de cumprir sua principal tarefa: educar.

É preciso considerar que a ausência de reprovação não escamoteia a falta de aprendizagem, pelo contrário, a progressão continuada tem contribuído para denunciar a pouca aprendizagem de muitos alunos, que antes era encoberta pela reprovação. Assim, a permanência dos alunos na escola, mesmo daqueles com baixo desempenho, tem produzido um profundo mal-estar em relação às condições de ensino e de aprendizagem, tanto entre os atores educacionais quanto na sociedade. Pode-se dizer que a escola básica brasileira encontra-se 
diante da difícil tarefa de democratizar o atendimento e garantir um ensino de qualidade à população.

Acredito que progressão continuada, como medida político-pedagógica, não tem a função de garantir, impedir ou dificultar a aprendizagem dos alunos, mas o objetivo de romper com o processo de seleção e exclusão operado pela reprovação. Sua incidência na aprendizagem ocorre à medida que contribui para os alunos permanecerem na escola e terem outras oportunidades. Entretanto, somente a permanência na escola não é suficiente para aprender: é necessário um conjunto de medidas que favoreçam a aprendizagem.

A progressão continuada, desprovida de medidas pedagógicas fundamentais ao processo ensino-aprendizagem - como tempos e metodologias diferenciados, reorganização dos conteúdos, número reduzido de alunos por sala de aula, atendimento em pequenos grupos fora do horário de aula para os alunos, com atraso ou dificuldades de aprendizagem (segundo os professores) -, embora mantenha o aluno na escola e permita-lhe uma progressão mais ou menos de acordo com o grupo de sua idade, não resolve o problema da aprendizagem.

\section{Legislação educacional: para que(m) serve a progressão continuada?}

Para que possamos discutir sobre a questão da progressão continuada, é importante buscar informações sobre o tema nos documentos oficiais. Desde o ano de 2005, com a alteração do ensino fundamental, conforme Lei Federal no 11.114/05, as escolas estaduais, municipais e privadas estão em um processo de reconfiguração baseado em um "novo" ensino: o ensino fundamental de nove anos.

A educação básica atual é marcada pela flexibilidade introduzida pela LDBEN n 9394/96, descentralizando as decisões, dando autonomia aos órgãos escolares através do exercício da democracia, levando em 
consideração a região e o local onde a escola ou instituição de ensino está inserida. Aos estabelecimentos de ensino é dada autonomia para a elaboração de seus regimentos, disciplinando sua organização curricular, pedagógica e administrativa, no que diz respeito à reorganização da escola como primeiro passo para a construção de um sistema educacional que tem como foco central a qualidade no ensino, como forma de preparar os jovens para as necessidades atuais e futuras da sociedade.

Como mudança maior dessa lei, a seriação deixa de ser o foco da organização curricular da escola tradicional. Ao repensar a educação, a LDBEN no 9394/96 resgata o respeito pelo ser humano na construção do conhecimento, assim, a mudança mais profunda que podemos perceber é a substituição da ênfase da repetência pela do sucesso.

Neste estudo contemplo também as orientações legais constantes nos documentos do Ministério da Educação (MEC), como forma de sistematizar e compreender as orientações do processo de implementação do ensino de nove anos. Tais documentos são: Ensino fundamental de nove anos: orientações gerais (2004); Ensino fundamental de nove anos: passo a passo do processo de implementação (2009); e os pareceres do Conselho Nacional de Educação (CNE) para a educação básica, do ano de 2008 e 2010.

Os documentos que orientam sobre o ensino de nove anos destacam que a criança, ao iniciar a escolarização aos 6 anos, terá mais tempo para se alfabetizar, então este um ano é um acréscimo no tempo de alfabetização. Assim, os documentos oficiais sugerem que $1^{\circ}, 2^{\circ}$ e $3^{\circ}$ ano do ensino fundamental compõem um "bloco de alfabetização".

O Pacto Nacional pela Alfabetização na Idade Certa, instituído pela Portaria $n^{\circ}$ 867/2012, é um compromisso formal assumido pelos governos federal, do Distrito Federal, dos estados e municípios para assegurar que todas as crianças estejam alfabetizadas até os 8 anos de idade, ao final do $3^{\circ}$ ano do ensino fundamental, legitimando o "bloco 
de alfabetização" enquanto um "espaço de tempo" reservado para alfabetização e letramento.

\section{Rede municipal de Eldorado do Sul/RS: a vida escolar em tempos de progressão continuada}

A Lei Federal $n^{\circ} 11.114 / 05$ alterou os artigos $6^{\circ}, 32^{\circ}$ e $87^{\circ}$ da LDBEN $\mathrm{n}^{\circ} 9394 / 96$, garantindo o ensino fundamental, obrigatório e gratuito, na escola pública a partir dos 6 anos. Com a implantação do ensino fundamental de nove anos, o Estado objetivou oferecer maiores oportunidades de aprendizagem, fazendo com que as crianças prossigam nos estudos, alcançando maior nível de escolaridade.

Ainda em 2005, o Conselho Estadual de Educação do Rio Grande do Sul (CEEd/RS) manifestou-se, através do Parecer no 752, sobre o ingresso obrigatório a partir dos 6 anos no ensino fundamental de nove anos, determinando procedimentos a serem adotados. Sobre a avaliação nos anos iniciais, o CEEd/RS estabelece que:

O $1^{\circ}$ ano do ensino fundamental de nove anos deverá ser desenvolvido como processo de aprendizagem de forma lúdica, respeitando a faixa etária das crianças, sua unicidade e sua lógica. A escola deve disponibilizar espaços, brinquedos, materiais didáticos e equipamentos que configurem o ambiente alfabetizador [...]. A avaliação deve ser diagnóstica, voltada para o acompanhamento do desenvolvimento da criança em seu processo de alfabetização de forma contínua e sistemática, expressa em parecer descritivo, sem a retenção do aluno. (CEEd/RS, Parecer $n^{\circ}$ 752/2005).

Diante das orientações legais, o Município de Eldorado do Sul, a partir do ano letivo de 2006 iniciou, de forma progressiva, a implantação do ensino fundamental de nove anos. Desde então, não há retenção da passagem do $1^{\circ}$ ao $2^{\circ}$ ano do ensino fundamental. 
No meu entendimento, tal medida constituiu-se como meramente administrativa, tendo em vista que não houve discussão e sequer proposta de formação continuada para os professores da rede municipal. Assim, as escolas organizadas pela estrutura seriada transformaram esse novo ano em mais uma série, com as características e a natureza ora da educação infantil, ora da $1^{\text {a }}$ série.

Quando da minha inserção na rede municipal de ensino, no ano de 2008, o alto índice de reprovação nas turmas de $2^{\circ}$ ano chamava atenção: dos 96 alunos matriculados, 31 reprovaram (Escola Municipal de Ensino Fundamental La Hire Guerra, 2010). Também ganhavam destaque as narrativas que equalizavam as propostas pedagógicas da educação infantil e do $1^{\circ}$ ano do ensino fundamental, assim como práticas avaliativas inadequadas, como se não houvesse compromisso com a aprendizagem das crianças de 6 anos.

No início do ano de 2013, o município aderiu ao Pacto Nacional pela Alfabetização na Idade Certa (PNAIC), adotando a progressão continuada no ciclo de alfabetização (do $1^{\circ}$ ao $3^{\circ}$ Ano). O PNAIC é uma ação que conta com a participação articulada do governo federal e dos governos estaduais e municipais, com o objetivo de mobilizar recursos e proporcionar materiais didáticos de qualidade, implementando sistemas adequados de avaliação, gestão e monitoramento para assegurar que todas as crianças estejam alfabetizadas até os 8 anos de idade.

A partir da adesão ao PNAIC, os professores que atuam no ciclo de alfabetização são inscritos em um programa de formação continuada, com o objetivo de apoiá-los a planejarem as aulas e a usarem de modo articulado os materiais e as referências curriculares e pedagógicas ofertados pelo MEC. No ano de 2013, os professores do ciclo de alfabetização da rede municipal de Eldorado do Sul participaram do referido programa com ênfase nas práticas de alfabetização e letramento. Em 2014, de acordo com o previsto pela Secretaria Municipal de Educação 
de Eldorado do Sul, deu-se início à formação com ênfase na alfabetização matemática. Cada professor alfabetizador recebe bolsa de estudo no valor de duzentos reais mensais.

É importante explicar que o ciclo de alfabetização nos anos iniciais do ensino fundamental é um tempo sequencial de três anos (600 dias letivos), sem interrupções, dedicados à inserção do aluno na cultura escolar, à aprendizagem da leitura e da escrita, à ampliação das capacidades de produção e compreensão de textos orais em situações familiares e não familiares e à ampliação do universo de suas referências culturais nas diferentes áreas do conhecimento. Nesse sentido, mesmo quando o sistema de ensino ou escola, no uso de sua autonomia, fizer opção pelo regime anual, será necessário considerar os três anos iniciais do ensino fundamental como um bloco pedagógico ou um ciclo sequencial não passível de interrupção, voltado a ampliar a todos os alunos as oportunidades de sistematização e aprofundamento das aprendizagens básicas, imprescindíveis para o prosseguimento dos estudos.

É evidente que a maior aprendizagem não depende do aumento do tempo de permanência na escola, mas sim do emprego mais eficaz do tempo. No entanto, a associação de ambos deve contribuir significativamente para que os educandos aprendam mais. Assim, o Ministério da Educação orienta que, nos seus projetos político-pedagógicos, sejam previstas estratégias que possibilitarão maior flexibilidade dos seus tempos, com menos cortes e descontinuidades (Brasil, 2004). Essas estratégias devem contribuir para o desenvolvimento do aluno, possibilitando-lhe, efetivamente, uma ampliação qualitativa do seu tempo na escola.

Contudo, o município tem grandes desafios a enfrentar. Muitos alunos concluem o ciclo destinado à sua alfabetização sem estarem plenamente alfabetizados. 


\section{"Vai passar mesmo!": problemas \\ de aprendizagem ou de ensinagem?}

Realizei entrevistas com professoras da rede municipal com a finalidade de complementar minhas análises sobre a implantação da progressão continuada em Eldorado do Sul e as práticas avaliativas dos docentes em exercício.

A falta de participação dos educadores no processo de formulação e implementação da proposta é um aspecto apontado em todas as entrevistas analisadas nesse estudo. As professoras registraram não terem tido uma preparação e/ou orientação sobre a progressão continuada e a não retenção nos anos iniciais do ensino fundamental, e quando isto ocorreu foi insuficiente. De acordo com P1,

[...] não houve orientação. $\mathrm{O}$ que houve ano passado (2012) foi que o Conselho Municipal de Educação encaminhou para as escolas uma orientação solicitando, por escrito, a opinião dos professores. [...] Pelo jeito esse material não foi lido, porque a maioria dos professores (aqueles que conheço/trabalho) não conheciam a questão da progressão continuada e/ou não eram a favor desta prática, justamente pelo município não ter esse suporte para oferecer. Quando da implantação do ensino fundamental de nove anos, com progressão continuada do $1^{\circ}$ para o $2^{\circ}$ ano, eu era professora do $2^{\circ}$ ano, e as crianças vinham com muitas dificuldades, com grande defasagem. Daí se dizia que haveria encontros com os professores alfabetizadores. No ano seguinte eu passei a trabalhar com $1^{\circ}$ ano (trabalhei os dois anos seguintes) e nunca mais ninguém tocou no assunto. Eu me senti bem perdida. [...].

Ainda de acordo com as professoras, as equipes gestoras das escolas não priorizaram a discussão sobre a progressão continuada, proporcionando pouca reflexão em torno da ruptura com a seriação e da necessidade de mudança na concepção de avaliação. 
Diante desse contexto, é possível compreender porque a discussão da reorganização do tempo e do espaço no âmbito escolar não ganha centralidade nas falas das professoras, registradas nesses estudos. $\mathrm{O}$ que se destaca é a preocupação com a restrição da possibilidade de reprovação dos alunos, associando a progressão continuada à promoção automática, em destaque na fala da $\mathrm{P} 1$, quando perguntada sobre seu posicionamento frente a esta proposta:

Eu acho que não é uma boa. Muitos vão passar sem ter o conhecimento necessário. [...] É igual a aprovação automática, sabe ou não sabe, vai igual. [...] É muito ruim eles não terem o conhecimento no $2^{\circ} \mathrm{e}$ no $3^{\circ}$ ano e serem aprovados. Eu já tive experiência, antes de acontecer essa não retenção, com alunos no $5^{\circ}$ ano que não sabiam ler... Chegavam no $5^{\circ}$ ano sem saber nada... Imagina agora.

Na apreciação das professoras, o objetivo da Secretaria Municipal de Educação de Eldorado do Sul é reduzir os índices de evasão e reprovação e economizar recursos. É importante destacar, ainda, que as educadoras, durante as entrevistas, consideraram as estatísticas um "faz de conta", expressando uma nova forma de exclusão dos alunos. P2 argumenta:

Eu vejo a não repetência pela não repetência. A progressão continuada não tem sentido pedagógico, serve para elevar os índices [IDEB]. [...].

Tal posicionamento também é evidenciado pelas demais professoras entrevistadas.

A análise de entrevistas com as professoras indicou que, apesar de reconhecerem os efeitos prejudiciais da reprovação, elas defendem esse 
mecanismo como instrumento que permite controlar a disciplina dos alunos e desenvolver neles a consciência da necessidade de estudar.

Ao abordar, nas entrevistas, a avaliação da aprendizagem, percebi que as professoras, ao considerarem que os alunos serão "aprovados automaticamente", julgam que a avaliação da aprendizagem "perdeu seu sentido". P2 enfatiza que

[...] têm professores que pensam que, como o aluno tem até $\mathrm{o} 3^{\circ}$ ano pra ler, não precisam se preocupar. E, assim, vão empurrando o aluno e deixando para a professora do ano seguinte. Só que daí, chega no $4^{\circ}$ [ano], e mal sabe ler e já tem muitos conteúdos a vencer.[...] Daí, no $4^{\circ}$ [ano], eu tenho que dar conta de uma lista de conteúdos e ainda ensinar o aluno a ler mais fluente.

Em suas narrativas, as professoras expressam a importância da avaliação contínua e do replanejamento do trabalho a partir de seus resultados, no entanto, a prática avaliativa sofreu pouca ou nenhuma influência com a implantação da progressão continuada. Para P5,

[..] muitos professores não se preocupam com a aprendizagem, dizem: "Vai passar mesmo...". Nem com a avaliação. Eu penso que deveria ter um apoio, que os alunos precisariam de algum acompanhamento... De alguém que os ajudasse a avançar, a aprender.

Acredito que essas circunstâncias e o caráter autoritário de implantação, sem discussão prévia com a comunidade escolar, são fatores determinantes da resistência dos professores da rede municipal de ensino de Eldorado do Sul. 
Nas opiniões das professoras, cabe destacar a solicitação de participação na formulação das políticas a serem implantadas, a garantia do trabalho coletivo entre os professores, o apoio às escolas pelos órgãos centrais das redes de ensino e atendimento mais adequado dos alunos com dificuldade de aprendizagem, visto que consideram insatisfatórias as atuais ações de recuperação e reforço devido, entre outros aspectos, a turmas numerosas, falta de espaço físico e escassez de docentes. P3, na entrevista, compartilhou sua angústia: "E tu sabe, na minha sala é complicado, eu tenho 31 alunos e mais a inclusão que acaba dificultando, [...]”. P4 é a favor da não retenção nos anos iniciais do ensino fundamental e da progressão continuada,

[...] desde que tenha suporte e número reduzido de alunos em sala de aula. Até acho que essa é a ideia do governo. Ter sala de recurso, ter avaliação diagnóstica, fazer todo um trabalho com aqueles que mais necessitam. A não retenção, assim como é aqui em Eldorado, que não tem atendimento especializado, não é o que acredito.

Os profissionais da educação na rede municipal de Eldorado do Sul têm vivenciado uma dicotomia no cotidiano escolar: reconhecem os efeitos prejudiciais da reprovação e a importância da ressignificação da avaliação da aprendizagem; contudo, a falta de espaço para discussão e a ausência de subsídios e condições que possibilitem a progressão escolar dos alunos com aprendizagem condizente dificultam a construção de uma organização democrática que garanta educação de qualidade para todos.

Como destaca Andrea Steinvascher (2003), a implantação da progressão continuada sem o acompanhamento de estratégias e subsídios para o enfrentamento da cultura e prática escolar dominante pode resultar numa desestabilização da dinâmica escolar que se pautava na 
decisão de aprovação/reprovação dos alunos; no entanto, novas regras poderão ser criadas dentro da mesma lógica seletiva e excludente.

\section{CONSIDERAÇÕES FINAIS}

Ao realizar este estudo, pude perceber que a proposta de progressão continuada nos Anos Iniciais, implantada na rede municipal de Eldorado do Sul, está fortemente permeada pela ideia da etapa anual e da retenção.

Destaco que, na organização da escola em regime de progressão continuada, não houve rupturas com a organização escolar seriada e também com a reprovação, pois essa aparece como "elemento" marcante. A reprovação é concebida, ainda, pelos professores como capaz de proporcionar melhora significativa da aprendizagem. Assim, ela passa a ser fator articulador para o sucesso da proposta.

É preciso considerar, também, que, se a escola não ensina, consequentemente o aluno não aprende. A questão central não é o "permanecer" na escola e sim possibilitar a aprendizagem ao aluno. Quando se critica e se nega a organização da escola em ciclos, tendo como justificativa que o aluno "passa de ano" sem saber conteúdos básicos, paralelamente aparecem fortes argumentos em favor dos ciclos, que não culpam o aluno pela repetência, mas colocam em questão a escola que não proporciona condições favoráveis de aprendizagem.

Embora a rede de ensino pesquisada adote oficialmente a progressão continuada no ciclo de alfabetização - três primeiros anos do ensino fundamental -, as tramas do seu cotidiano estão envoltas na organização seriada, com defesa da homogeneização das turmas, processo de avaliação centrado em notas e, consequentemente, classificações dos educandos, que reforçam elementos da avaliação informal que permeia todo o sistema.

Assim, as representações dos professores mostraram que a organização ciclada da rede municipal de ensino encontra-se apenas como 
medida paliativa que atende ao objetivo de regularizar o fluxo de alunos e a distorção idade/série. Portanto, é fundamental que os docentes se envolvam e reflitam sobre impasses e valores ideológicos que permeiam suas práticas e se percebam enquanto parte do processo de implantação de novas propostas. O caminho é sinuoso, mas é preciso seguir, significando assim resistência contra a exclusão escolar e, paralelamente, social.

\section{REFERÊNCIAS}

BRASIL. Lei $n^{\circ}$ 9.394, de 20 de dezembro de 1996. Estabelece as diretrizes e bases da educação nacional. Brasília, 1996.

. Lei $n^{\circ} 11.274$, de 6 de fevereiro de 2006. Altera a redação dos artigos 29, 30, 32 e 87 da Lei $n^{\circ}$ 9.394, de 20 de dezembro de 1996, que estabelece as diretrizes e bases da educação nacional, dispondo sobre a duração de 09 (nove) anos para o ensino fundamental, com matrícula obrigatória a partir dos 06 (seis) anos de idade. Brasília, 2006.

. Ministério da Educação. Conselho Nacional de Educação. Resolução $C N E / C E B n^{\circ} 2$, de 30 de janeiro de 2012. Define diretrizes curriculares nacionais para o ensino médio. Brasília, 2012.

. Ministério da Educação. Conselho Nacional de Educação. Resolução $C N E / C E B n^{\circ} 4$, de 13 de julho de 2010. Define diretrizes curriculares gerais para a educação básica. Brasília, 2010.

. Ministério da Educação. Conselho Nacional de Educação. Resolução $C N E / C E B n^{\circ} 7$, de 14 de dezembro de 2010. Fixa diretrizes curriculares nacionais para o ensino fundamental de 9 (nove) anos.

Ministério da Educação. Portaria no 867, de 4 de julho de 2012. Institui o pacto nacional pela alfabetização na idade certa e as ações do pacto e define suas diretrizes gerais. Diário Oficial da União. Brasília, DF, 5 jul. 2012. Seção 1, p. 22. 
BRASIL. Ministério da Educação. Secretaria de Educação Básica. Ensino fundamental de nove anos: orientações gerais. Brasília, 2004.

- Ministério da Educação. Secretaria de Educação Básica. Ensino fundamental de nove anos: passo a passo do processo de implantação. 2. ed. Brasília, set. 2009.

ESCOLA MUNICIPAL DE ENSINO FUNDAMENTAL LA HIRE GUERRA. Projeto político-pedagógico. Eldorado do Sul, 2010. 67 p. (impresso)

HOFFMANN, J. Avaliação mediadora: uma prática em construção da pré-escola à universidade. 4. ed. Porto Alegre: Educação e Realidade, 1993.

. Avaliação: mito e desafio - uma perspectiva construtivista. Porto Alegre: Mediação, 1991.

Avaliar para promover: as setas do caminho. Porto Alegre: Mediação, 2001.

. Pontos e contrapontos: do pensar ao agir em avaliação. Porto Alegre: Mediação, 2007.

LÜDKE, M.; ANDRÉ, M. E. D. A. Pesquisa em educação: abordagens qualitativas. São Paulo: EPU, 1986.

PERRENOUD, P. Avaliação: da excelência à regulação das aprendizagens entre duas lógicas. Porto Alegre: Artmed, 1999.

. Os ciclos de aprendizagem: um caminho para combater o fracasso escolar. Porto Alegre: Artmed, 2004.

. Ensinar: agir na urgência e decidir na incerteza. Porto Alegre: Artes Médicas, 1991.

STEINVASCHER, A. A implantação da progressão continuada no estado de São Paulo: um caminho para a democratização do ensino? Dissertação de Mestrado, Faculdade de Educação, Universidade de São Paulo, São Paulo, 2003.

VASCONCELLOS, C. S. Avaliação da aprendizagem - práticas de mudança: por uma práxis transformadora. São Paulo: Libertad, 2003. 


\section{(Re)Conhecendo o povo Mbya Guarani: um olhar para os Kyringue Andréia Rosa da Silva Kurroschi}

Em consonância com o que estabelece a Lei $n^{\circ} 11.645 / 2008$, que institui como obrigatório o estudo da história e da cultura afro-brasileira e indígena nos níveis fundamental e médio da educação básica, este capítulo apresenta a temática indígena através do olhar direcionado para as crianças do povo indígena ${ }^{1}$ Mbya Guarani residentes na Tekoa ${ }^{2}$ Anhetengua, no bairro Lomba do Pinheiro, zona leste do município de Porto Alegre.

Os objetivos da pesquisa são: descrever as crianças Mbya Guarani e suas relações com a escola; compreender seus processos de

\footnotetext{
${ }^{1}$ Em concordância com Medeiros apud Oit (2012) “[...] utilizo o conceito povos indígenas conforme entendido pela Convenção no 169 da Organização Internacional do Trabalho sobre Povos Indígenas e Tribais de 1989, ratificada pelo estado brasileiro em 2004 por meio do Decreto n 5051 e pela Declaração das Nações Unidas sobre os Povos Indígenas, aprovada em Assembleia Geral em 2007. De acordo com esses documentos, o termo povos 'caracteriza segmentos nacionais com identidade e organização próprias, cosmovisão específica e relação especial com a terra que habitam'." (p. 13).

${ }^{2}$ Em Mbya Guarani, a palavra Tekoa significa aldeia.
} 


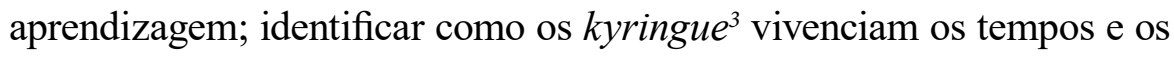
espaços dentro da escola específica e diferenciada e na comunidade. Os rumos do trabalho são balizados pelas questões de pesquisa: quem são as crianças Mbya Guarani da Tekoa Anhetengua? Com o que se ocupam? O que fazem e o que mais gostam de fazer? Como é sua relação com a escola?

Para dar conta dessas demandas, mantive o olhar voltado para a turma do professor Jair ${ }^{4}$ : um grupo de oito crianças, entre 10 e 14 anos, que formam o $3^{\circ}$ e $4^{\circ}$ anos do ensino fundamental de nove anos. Esses alunos foram reunidos em uma única turma, e as aulas ocorrem no turno da manhã.

Não são as idades que identificam em que ano escolar os alunos devem estar, e sim se eles apresentam condições para seguirem adiante. Em conversa com o professor Jair, ele me disse que quando o docente sente que o aluno está preparado para avançar, isso acontece automaticamente, em qualquer etapa do ano, independentemente da idade. No meu entender, isso evidencia que há um respeito profundo com o tempo de cada um, com um olhar atento às suas aprendizagens, seu jeito de ser e estar na escola e, também, fora dela, sem uma preocupação com a idade cronológica, e sim com as etapas da vida que devem ser contempladas.

Para descrever os modos de vida desses grupos, fiz da convivência na escola e na comunidade elementos essenciais para o trabalho de campo, já que "[...] sem um contato intenso e prolongado com a cultura ou grupo em estudo será impossível ao pesquisador descobrir como seu sistema de significados culturais está organizado, como se desenvolveu e influencia o comportamento grupal" (Godoy, 1995, p. 28).

\footnotetext{
${ }^{3}$ Em Mbya Guarani, a palavra kyringue significa crianças, criançada.

${ }^{4}$ Os nomes utilizados no trabalho são fictícios, conforme explicitado no decorrer do texto.
} 
Desse modo, busquei um contato direto e prolongado com o ambiente que compreende a escola, mas também com o seu entorno (Lüdke; André, 1986), sendo esse um dos aspectos da pesquisa qualitativa de cunho etnográfico a que esse trabalho se propõe.

Ao escolher a Tekoa Anhetengua para compartilhar da convivência dos Mbya Guarani, também procurei ter em meu diário de campo um instrumento inevitável e imperativo (Fonseca, 1999) para registrar minhas vivências, meus estranhamentos e encantamentos nesse "estar-junto", pois, "sem um planejamento fechado do que fazer, elegi como importante, para observar na vida Guarani, todas as pequenas coisas, os detalhes, os silêncios, os olhares, a intensidade da vida diária e seus pequenos nadas" (Bergamaschi, 2005a, p. 48), relacionando as questões pertinentes da pesquisa aos objetivos elencados. E foi exatamente dessa forma que se deu a minha primeira incursão no ano de 2013 na Tekoa com o início efetivo da investigação.

Minha primeira ida a Tekoá Anhetengua no ano de 2013. Um friozinho na barriga e a inquietação de ser justamente um dia chuvoso. Sei que a chuva é necessária, mas além de atrapalhar o deslocamento até a aldeia, já que Porto Alegre fica toda alagada, faz com que o Povo Guarani fique mais recolhido. [...] Eu comecei a ficar incomodada em estar toda molhada esperando o ônibus que, aliás, demorou bastante. Finalmente depois de muito tempo estávamos nos encaminhando para a Lomba. (Diário de campo, 20/03/2013).

A chuva é um elemento relevante a se destacar, visto que faz com que os Guarani permaneçam mais introspectivos, pois são dias

\footnotetext{
${ }^{5}$ Essa expressão foi utilizada na tese Nhembo'e: enquanto o encanto permanece! Processos e práticas de escolarização nas aldeias Guarani, de Maria Aparecida Bergamaschi inspirada nos estudos de Michel Maffesoli.
} 
de recolhimento em que não há disposição para receberem os jurua ${ }^{6}$ tampouco ter aula na escola. Esse é o modo de ser Mbya Guarani, ou seja, o Nhande Reko, em que o tempo para viver a sua cultura é respeitado (Bergamaschi, 2005a), sendo também um indicativo da escola específica e diferenciada que eles se propõem a ter, já que esse item decisão de ter ou não aula em dias de chuva - consta no Regulamento da Escola Estadual Anhetengua, aliás, mesmo nome que recebe a Tekoa.

Cheguei, e a Tekoa estava muito silenciosa, com pouco movimento. Fui recebida pelo professor Heleno que logo me informou que, pela manhã, havia ocorrido uma limpeza na aldeia com a participação de todos e que, naquele momento, a maioria estava descansando. Quando vi a escola fechada, resolvi perguntar se haveria aula, talvez para confirmar com ele, na prática, o que sabia somente na teoria. Ele, muito paciente, explicou que as crianças participaram da coleta de lixo pela manhã, segundo suas palavras, "um outro modo de aprender" e que, por isso, foi decidido que naquele dia não teria aula. (Diário de campo, 20/03/2013).

Essas questões relativas ao tempo ainda me desacomodam, já que fazem emergir em mim a dificuldade em compreender a escola específica e diferenciada que os indígenas querem ter em suas comunidades.

${ }^{6}$ Jurua significa todas as pessoas não indígenas, bem como sua língua e seu modo de ser não índio. 
Tenho prazos que não se encaixam no tempo vivido na aldeia, e então vêm os questionamentos: estou no caminho certo? Vou conseguir material empírico para o meu trabalho? Será que conseguirei assistir a uma aula na escola? E conhecer as crianças? Porém minha determinação é maior do que as dúvidas! (Diário de campo, 27/03/2013).

É nesse caminho que busco, em meus estudos e em minhas reflexões, modos de compreender como é a temporalidade da vida Mbya Guarani, pois percebo que há uma conexão entre os aprendizados ditos escolares, em que se ensina o português e a matemática, e o modo de ser Guarani, o Nhande Reko, numa convivência presente em todos os espaços da Tekoa, em especial no convívio com os irmãos e as irmãs mais velhos/velhas. A partir dessas pausas de leitura específica sobre a temática é que vão se acomodando minhas angústias e ansiedades e dando ainda mais sentido ao meu estar entre os Mbya.

A sensação de chegar à aldeia e ver a escola com as crianças do terceiro e quarto anos encheu meu coração de alegria. Primeira oportunidade de ver uma aula acontecendo. Será? O olhar viciado pelo etnocentrismo por alguns instantes fez com que eu acreditasse que a educação acontece apenas naquele espaço diminuto em que se localiza a Escola Estadual Anhetengua da Lomba do Pinheiro. É nessa escola bilíngue, em que convivem o idioma Mbya Guarani e o Português, que os indígenas tomam conhecimento do "mundo dos brancos" através de sua instituição essencialmente homogeneizadora, mas que, nesse espaço da Tekoa, não encontra terra fértil, pois cada pessoa Guarani é respeitada em suas singularidades.

Antes de finalizar a aula, o professor me concedeu a palavra para que eu pudesse conversar com as crianças. Após a apresentação, fiz a entrega de blocos de desenhos, previamente confeccionados, solicitando, em 
seguida, que levassem um para casa e desenhassem o que mais gostavam de brincar e me devolvessem na semana seguinte. Esse artefato tinha espaço para a colocação do nome e da idade, fazendo com que eu pudesse nominar aqueles que seriam meus companheiros pelos próximos meses. Posteriormente percebi que essa combinação de "levar para casa e trazer depois" não funcionaria como eu imaginava, visto que os blocos não retornaram no encontro seguinte, pois eles haviam esquecido em casa. Refleti, e, conversando com o professor, decidimos que esse tipo de atividade seria realizado no período da aula, na escola.

Além dos desenhos, as fotografias feitas por mim e também pelos alunos se constituíram em materiais relevantes na metodologia de pesquisa, essenciais para as posteriores análises e reflexões sobre as questões orientadoras desse trabalho.

Para fins da pesquisa, precisei eleger nomes fictícios para os professores e alunos descritos e, em um primeiro momento, conversei com o professor Jair a respeito do assunto, pensando que eles mesmos poderiam escolher como gostariam de ser chamados. Para os Mbya seus nomes em português cumprem uma exigência legal para a emissão de documentos, uma vez que têm na nomeação recebida pelo Karai ou Kunha Karai, em ritual que ocorre quando a criança tem aproximadamente entre oito meses e um ano de vida, a palavra-nome revelada, ou seja, esse líder espiritual da aldeia é um mediador que recebe das divindades a missão de batizar os kyringue afirmando ou atribuindo características individuais (Bergamaschi; Menezes, 2009). Entendendo essas particularidades, relembrando "que a palavra para o Guarani é poder” (Bergamaschi; Menezes, 2009, p. 63) e, a partir das colocações do professor Jair, decidi eu mesma nomeá-los.

Para cumprir essa etapa, resolvi utilizar nomes de jogadores de futebol por ser esse um esporte bastante apreciado e praticado na aldeia. A partir da primeira letra de cada nome original, fiz a correspondência 
com os nomes de atletas de equipes importantes, algumas das quais os Mbya são torcedores, inclusive manifestando essas preferências ao utilizarem camisetas ou outros símbolos de seus times.

O curso de extensão de ensino da língua Mbya Guarani me proporcionou a oportunidade de um aprendizado mais amplo do que apenas as palavras do idioma predominantemente falado pelas crianças na Tekoa. Através dessas aulas, venho entendendo o uso de expressões em seus contextos específicos, o que faz com que eu possa me sentir mais inserida no teko, ou seja, na vida Guarani.

\section{OS MBYA GUARANI}

Superando a concepção generalizadora dos povos ameríndios, que, em muitas situações, são apresentados sem um reconhecimento das singularidades étnico-culturais, apresento os Mbya, uma das parcialidades Guarani, que, juntamente com os Nhandeva e Kaiowa, habitam um “[...] território que se estende por Paraguai, Brasil e Argentina, com um caráter transfronteiriço que os Estados desses países têm muita dificuldade em reconhecer" (Meliá, 2010, p. 37).

O povo Mbya Guarani soma-se às mais de 240 etnias formadoras da multiplicidade de povos indígenas existentes em nosso país. Com suas aproximadamente 180 línguas (Bergamaschi, 2010), ele contrasta com a denominação genérica de "índio" presente no senso comum e que desconsidera "[...] a diversidade das formas de vida, as trajetórias e apropriações que cada grupo fez nas relações de contato" quando da chegada dos europeus à América até os dias de hoje (Bergamaschi, 2005b, p. 402).

Em um processo de afirmação étnica e com o intuito de viver o Nhande reko, os Mbya preservam a sua língua, denominada de Mbya Guarani. Predominantemente falada entre as crianças com as quais convivi durante o tempo da pesquisa, o idioma também está presente nos diálogos entre os adultos e dos professores com seus alunos, 
ficando o português restrito à comunicação com os jurua e ao ensino ocorrido no ambiente escolar.

Os Mbya Guarani organizam-se em aldeias denominadas de Tekoa, ou seja, um espaço apropriado para que seus moradores possam viver o teko. De acordo com Meliá (apud Mouzer, 2011, p. 20, grifos do autor),

A Tekoa não pode reduzir-se à propriedade privada de um pedaço de terra; a Tekoa é a terra manejada segundo o teko. O fundamental evidentemente é o teko, ou seja, os costumes, os valores, as referências éticas e obrigações sociais de um conjunto de famílias unidas pela mesma linguagem.

Os Mbya Guarani estão estabelecidos na Tekoa Anhetengua, aldeia que possui aproximadamente dez hectares, com uma população de cerca de oitenta pessoas, boa parte ligada por algum grau de parentesco, fato comum nas comunidades Guarani. Na entrada da aldeia podemos visualizar um pátio circundado pela escola, tendo o Posto de Saúde logo atrás e a casa provisória do cacique bem à frente. Essa construção está projetada para ser o futuro Centro Cultural da Tekoa. Atravessando uma pequena estrada, com algumas residências, pode-se ver outro pátio onde fica a $O p y,{ }^{7}$ a casa de reza dos Mbya.

$\mathrm{Na}$ concepção indígena, Tekoa Anhetengua significa Aldeia da Verdade, conforme relato dos professores com os quais conversei. De fato existe uma sintonia, um bem-estar, uma conexão, algo talvez inexplicável com palavras escritas, mas dotado de sentimentos muito verdadeiros sempre quando me aproximo do portão de entrada da Tekoa. Mesmo que ela tenha construções bastante modestas e precárias do nosso ponto de vista, esteja muito próxima a uma estrada movimentada, com intenso fluxo de ônibus, carros e caminhões, e cercada por

${ }^{7}$ Casa tradicional de reza. Lugar sagrado do estar juntos espacial e temporal do povo Guarani. 
uma vizinhança não indígena, tudo isso se dilui pelo espírito de liberdade que habita aquele lugar.

\section{A $\varepsilon S C O L A \&$ AS CRIANÇAS MBYA}

A Escola Estadual Indígena de Ensino Fundamental Anhetengua fica no centro da Tekoa. Além de mesas, cadeiras e quadro-negro, a construção de madeira abriga uma cozinha improvisada, em que é preparada a merenda escolar, e um espaço com computadores, provocando um entulhamento no ambiente. Existe uma reivindicação antiga da comunidade para a ampliação do prédio, com um espaço mais digno e que atenda às especificidades do povo Mbya Guarani, porém isso ainda não foi providenciado pelo governo estadual, seu responsável direto.

A escola é um lugar de encontros, reuniões e decisões da comunidade e, portanto, bastante frequentada. Por ser um espaço único, sem divisões de salas, precisou se adequar para dar conta das pessoas que nela estudam do $1^{\circ}$ ao $7^{\circ}$ ano do ensino fundamental, além da turma de educação de jovens e adultos (EJA). Sendo assim, as turmas ficam agrupadas para serem contempladas na utilização do espaço escolar. Conforme relato dos professores e também do cacique, à noite não tem aula, como comumente vemos ocorrer na modalidade da EJA, pois esse período é reservado para a ida a $O p y$, assim como para momentos de reunião das famílias com o intuito de estarem juntos.

Desde a Constituição de 1988, existe legislação ${ }^{8}$ que permite aos indígenas terem uma escola específica e diferenciada em suas comunidades. Assemelha-se ao modelo ocidental de escola quando observamos a disposição das classes, as paredes cobertas de cartazes, contendo algarismos e o alfabeto, a presença do quadro verde e o professor como figura central do processo de ensino-aprendizagem, porém as diferenças são

\footnotetext{
${ }^{8}$ Para aprofundamento, sugiro a leitura do artigo de Iara Tatiana Bonin - "Educação escolar indígena e docência: princípios e normas na legislação em vigor” - constante no livro Povos indígenas \& educação, de 2012.
} 
muitas, dentre elas o bilinguismo. O idioma de origem é ensinado concomitantemente à língua portuguesa e os preceitos do modo de vida Mbya Guarani, que são pautados pelo respeito ao tempo de cada um na formação da pessoa Guarani, aspecto esse ressaltado pelas palavras do professor Jerônimo, conforme Bergamaschi (2012, p. 12):

$\mathrm{Na}$ escola tem que falar com calma, com suavidade com as crianças. Isso é a escola diferenciada para o Guarani. Parece igual, mas a diferença está na dimensão espiritual, que respeita cada criança, sua vontade. Não pode falar alto, tem que ter delicadeza com a criança.

A escola, tida por Silva (2002) como "instituição homogeneizadora por excelência”, é um direito dos povos indígenas, entretanto, sua presença nas comunidades é opcional, ou seja, em algumas aldeias, ela não é constituída. Um dos objetivos de ter escolas na aldeia é "o domínio de conhecimentos e tecnologias específicos que elas podem favorecer", assim como a aprendizagem da língua portuguesa (Silva, 2002, p. 57).

Esse modo de ser da escola faz com que a escolha do professor seja realizada pela comunidade, o que, na escola Anhetengua, consta em seu Regulamento Interno. Diante disso, o professor Jair, que tem 30 anos de idade e uma experiência de três anos como docente, foi designado para compor o trio de educadores indígenas dessa comunidade, juntamente com os professores Jardel e Heleno.

O trecho que segue do meu diário de campo aborda algumas questões centrais da relação das crianças Mbya Guarani com a escola: o tom de voz, o silêncio, a atenção, o envolvimento e a curiosidade - elementos que nos fazem compreender como acontecem seus processos de aprendizagem e como elas vivenciam os tempos e espaços escolares. 
Com as falas em Guarani, professor e alunos se comunicaram em um tom baixo e respeitoso. $\mathrm{O}$ professor tem autoridade sem precisar levantar a voz, mesmo com a sua filha, a quem o Jair se dirigia algumas vezes quando ela queria conversar com as meninas. Isso foi interessante: a presença da menina não distraía os alunos. Eles pareciam determinados a concluir a tarefa, mesmo com o pouco repertório que o único jornal presente na aula oferecia. $\mathrm{O}$ silêncio. Inquietante companheiro de uma jurua sedenta de respostas, mas reconfortante ao me dar conta de que esses alunos querem muito aprender e, por isso, se concentram. Ou será que o silêncio na aula é uma marca constante da importância que as palavras têm para os $M b y a$ ? Provavelmente, a afirmação e a pergunta se completam num exercício de encantamento em que o conhecimento e a contemplação sejam elementos que vão formar a pessoa Guarani. (Diário de campo, 02/04/2013).

Quando o professor se encaminha para a escola, com o intuito de iniciar sua aula, automaticamente é seguido por seus alunos que, em silêncio, entram no prédio e ocupam seus lugares, geralmente sentando-se em duplas ou em trios. Após os cumprimentos em sua língua nativa, o professor começa a escrever no quadro a tarefa do dia, e, com isso, rapidamente os cadernos são abertos, e todos começam a copiar. Entre explicações e perguntas, o tom de voz baixo e respeitoso, assim como o silêncio, vindos tanto do professor quanto dos alunos, propicia um envolvimento com a tarefa proposta no quadro. A presença de crianças menores e, mesmo, de pequenos animais não é motivo para a distração dos alunos, demonstrando, como constatei em minhas anotações, que as crianças fazem da escola um espaço prazeroso e que lá permanecem pela curiosidade que mostram com o aprender. 


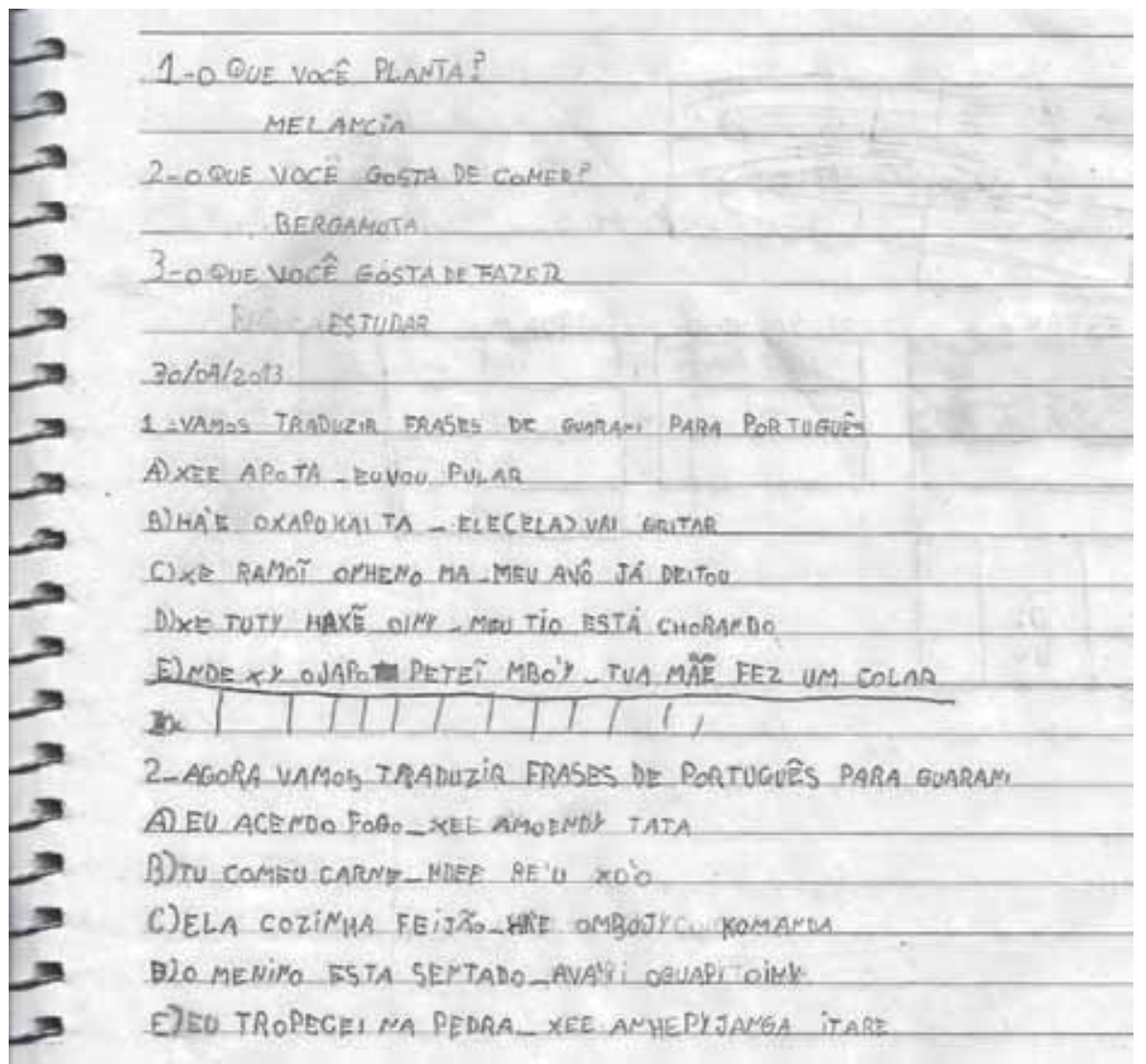

Caderno da Leah, 11 anos.

Esse fragmento do caderno da Leah, de 11 anos, com frases nos dois idiomas, confirma o aprendizado bilíngue ocorrido na escola Anhetengua. Ao ler o conteúdo das frases, relembrei algumas aulas que tive durante minha formação acadêmica em Pedagogia, quando os professores frisavam a importância de um aprendizado que valoriza a realidade dos alunos. 
Entreguei a cada um o bloco de desenho, pedi que escrevessem o nome e a idade e desenhassem alguma coisa bem bonita para me mostrar. Foi rápida a mobilização. Em silêncio todos se concentraram em seus desenhos. Achei bem interessante a atitude da Leah, pois, quando comecei a passar entre as crianças para ver seus desenhos, perguntei o que era e pedi que escrevessem ao lado o nome de algum animal desenhado. Atenta, quando cheguei perto dela e vi seu desenho, percebi que ela havia nomeado tudo: pássaros, casa, flor, árvore, nuvem e sol. Impressionante a riqueza de detalhes, demonstrando bem que essa contemplação que eles têm se manifesta em suas produções. O Falcão fez um desenho lindo com várias casas e, quando indaguei que lugar era aquele, ele disse que tinha visto em sonho. (Diário de campo, 09/04/2013).

Duas das características predominantes entre os Mbya Guarani, que encontra eco entre os A'uw ẽ-Xavante (Silva, 2002), é a atenção e os sonhos como formas de aprendizagem (Bergamaschi, 2005a). Quando a menina Leah nomeou todos os elementos que compunha seu desenho, depois de ouvir uma conversa minha com outro aluno, em que sugeri que ele escrevesse o nome do animal desenhado, ela demonstrou estar atenta ao que acontecia à sua volta. Já o menino Falcão, 14 anos, quando indagado sobre sua produção, disse que aquele lugar desenhado tinha sido visto por ele em um sonho, fazendo com que eu entendesse que existe "[...] um acervo de conhecimentos, nomes pessoais, rituais, danças e cantos [...] nessa outra dimensão existencial” (Silva, 2002, p. 45), o que pode ser conflituoso com a nossa forma tão distinta de conceber o aprendizado escolar. 
Assim que o professor falou com a turma em Guarani e começou a escrever no quadro, a sala ficou totalmente em silêncio. Todos copiando os desenhos e as primeiras letras de cada fruta para depois completarem. Algumas perguntas, em Guarani, foram feitas pelos alunos, e o professor ia explicando para toda a turma. Foi uma atividade rápida, todos fizeram. É importante salientar que o professor não estipula um tempo para as tarefas. Ele simplesmente passa no quadro e vai respondendo as eventuais perguntas. Quando percebe que todos terminaram, inicia a correção no quadro. Aliás, eles adoram escrever no quadro. Ninguém se esquiva de escrever suas respostas e, para isso, levam o caderno para copiarem. Não há a pressa comum em nossas escolas, até porque não existe uma ansiedade em passar conteúdos, mas sim uma vontade de que todos copiem, entendam, aprendam. Uma prática comum é a leitura coletiva depois da correção no quadro. (Diário de campo, 09/04/2013).

A temporalidade é um aspecto muito interessante de se entender nessa escola específica e diferenciada, pois não há uma imposição para o término das tarefas. Esta é uma atitude recorrente por parte do professor Jair e, também, percebida durante as aulas do professor Jardel: a falta de pressa. Muitas vezes um único exercício é realizado durante todo o período de aula. Diante disso, constatei que os Mbya Guarani são pessoas que vivem o presente, sem ansiedade em relação ao que está por vir. Isso foi evidenciado muito em função da relação entre os tempos vividos na escola, a forma como as tarefas são solicitadas e a maneira como são realizadas. De acordo com o que Bergamaschi (2005a, p. 229) nos coloca,

[...] cada criança faz sua atividade em seu tempo, pois não há, por parte do professor, nenhuma imposição de regras temporais, como nos habituamos em nossas escolas, cujas 
atividades são planejadas para determinado período de execução, tempo esse explicitado e treinado junto aos alunos e que, por vezes, funciona como ameaça: "tem mais dez minutos para concluir o trabalho!"

A frequência dos alunos é um fator de estranhamento perante o nosso pragmatismo que determina os tempos escolares das escolas não indígenas. É difícil compreender que não há uma obrigação em ir para a escola, pois há um respeito pela vontade de cada pessoa. Conforme palavras do professor Jair, "eles vêm quando sentem vontade". As meninas são respeitadas durante o seu período menstrual, tido como momento de recolhimento, e, portanto, não precisam comparecer às aulas. O tempo nas comunidades indígenas não é linear como aquele com que nos habituamos a conviver. Mesmo em suas narrativas, é comum percebemos um vaivém de fatos e histórias, como um tempo circular, uma teia que estabelece conexões de acordo com o que os índios privilegiam como mais importante a ser revelado.

Durante as aulas, há uma sistematização que consiste em copiarem do quadro, realizarem as atividades, corrigirem coletivamente e, depois, fazerem a leitura em voz alta, expressando, assim, a oralidade, uma das características dos povos ameríndios. Quando o professor Jair propõe uma tarefa, ele costuma colocar um exemplo para que seus alunos compreendam como devem dar continuidade ao exercício. Essa repetição, somada aos constantes exemplos, pode soar como monótona ou, até mesmo, ser vista como tradicional se comparada a uma escola não indígena, porém faz parte da aprendizagem do povo Mbya Guarani. E isso não é somente na escola, mas parece ter relação com todo o aprendizado para ser uma pessoa Guarani.

A educação é toda a vida Guarani! Essa frase parece ser uma constante durante esse tempo da pesquisa, e, embora as crianças tenham uma interação muito atenciosa com a escola, esse é apenas um dos espaços em que elas aprendem e se relacionam. A ausência de temas 
de casa é um aspecto que marca o tempo escolar: enquanto permanecem na aula há o encantamento, o envolvimento e a atenção respeitosa; quando ela encerra, outro período de aprendizagem se descortina.

Ao rememorar as minhas visitas à aldeia, destaco um dia que não teve aula no período da manhã, pois a escola estava ocupada com uma reunião entre as lideranças da Tekoa Anhetengua e representantes do poder público. Quando, por volta do meio-dia, fiquei sozinha em frente à escola, tive a impressão de que o dia estava "perdido": a reunião havia acabado, as pessoas retornaram para suas casas, e eu permaneci tentando entender o que poderia aproveitar daquela convivência entre os Guarani que estavam envolvidos em suas atividades rotineiras.

De repente entra o caminhão das frutas e verduras. Eu já havia presenciado anteriormente essa cena. Quando o caminhão entra na aldeia, surgem mulheres e crianças para comprarem os alimentos. Aproveitei e comprei bergamota. Era um dia frio e ensolarado, e pensei que seria uma forma de me aproximar das crianças. Acertei "na mosca". Assim que eu abri o saco de bergamotas e comecei a comer, algumas crianças que estavam em volta do caminhão me olharam. Ofereci para elas, que rapidamente aceitaram a minha oferta, e, em seguida, o saco estava vazio. Importante registrar que normalmente as pessoas da aldeia comem as frutas e jogam as cascas ao chão. É uma prática comum e que, conforme conversei com a Cida há algum tempo, demonstra que, para eles, tudo o que a terra te dá ela absorve, portanto não é falta de educação nem desleixo. Porém eu tenho o hábito de utilizar a sacola plástica e dela fazer a minha lixeira. E foi assim que procedi: à medida que ia descascando as bergamotas, colocava as cascas em uma sacola plástica próxima a mim, assim como as sementes. Achei incrível que, sem eu dizer uma só palavra, as crianças fizeram exatamente a mesma coisa. É 
uma percepção rápida, um movimento que não se traduz com palavras, e sim com observação e imitação. Eu tenho percebido que isso acontece muito com as crianças: elas são muito observadoras e aprendem constantemente com os mais velhos, sejam eles os irmãos, pais e mães. (Diário de campo, 06/05/2013).

As crianças têm uma predisposição para aprenderem e se relacionarem entre si e com os jurua. Mesmo com a falta de um entendimento mais eficaz com os menores, já que eles não frequentam a escola e, portanto, não falam o português, isso não foi um empecilho para nossa comunicação acontecer por meio de outras linguagens. De repente me deparei convivendo e participando de brincadeiras que, até então, não havia presenciado. Uma delas ocorreu pela interação com duas meninas com idade próxima aos dois anos. As duas vieram ao meu encontro, comeram bergamota e, depois, retornaram, carregando suas bonecas e sacolas com alguns pertences de "suas filhas". Fiquei observando a delicadeza dos gestos. As bonecas, certamente doadas, pois já estavam com os rostos e corpos riscados com caneta esferográfica, eram cuidadosamente carregadas, colocadas no banco ao meu lado e tinham suas roupas trocadas conforme as meninas iam tirando alguns panos de dentro das sacolas. Depois de um tempo, elas me entregaram as bonecas para eu segurar, mas logo em seguida as pegaram de volta e continuaram seu passeio pela aldeia. Foi a primeira vez que vi uma brincadeira diferente do habitual jogo de bola e foi oportuno perceber a semelhança com relatos de brincadeiras de casinha das crianças A’uwẽ-Xavante, assim como das que ocorrem entre crianças não indígenas, evidenciando que esse modelo de brincar acontece envolto na mesma atmosfera em vários outros lugares (Nunes, 2002), mesmo que em circunstâncias e culturas tão distintas. 
Quanto à atitude das crianças perante o descarte das cascas de bergamota, concordo com a constatação de Bergamaschi (2005a, p. 155), que descreve: “[...] a pessoa é, desde pequena, uma observadora da natureza, da qual se sente parte, e a tem como fonte inspiradora de vida e de educação, mas é também uma observadora dos comportamentos de outras pessoas”. A observação e a repetição não são exclusividade do ambiente escolar, já referido anteriormente, mas uma constante na educação Mbya Guarani, assim como em outras etnias indígenas, pois, a cada repetição,

[...] elas tentam novas possibilidades, enfrentam novos desafios, afirmam um novo saber. Além do mais, o fato de se empenharem em tanta repetição, não obstante a isso não estejam obrigadas, ou seja, o fazem espontaneamente, indica que a criança tem, conscientemente ou não, e ainda que circunscrito a breves momentos, interesse pelo que está fazendo. A insistência na repetição cria, portanto, oportunidades para melhorar a performance, permite a tranquilidade de sair de uma base segura e ser audacioso, abre caminho para a invenção. (Nunes, 2002, p. 82-83).

A reciprocidade é um aspecto encantador presente no modo de vida Guarani, pois busca acolher as pessoas, geralmente oferecendo-lhes produtos provenientes da terra. Além disso, é um modo de entender e respeitar a individualidade de cada pessoa ao mesmo tempo em que a insere como parte integrante do coletivo da aldeia. E foi assim que me senti quando recebi de forma tão carinhosa as frutas colhidas pelas crianças em retribuição ao alimento que juntas compartilhamos. É um gesto de puro sentimento, que demonstra a generosidade desse povo para com aqueles que convivem e respeitam sua forma de estar no mundo.

O convívio afetuoso das crianças com seus irmãos é um destaque nos espaços de convivência da aldeia. Os irmãos maiores, além de serem imitados, são os que permanecem a maior parte do tempo com 
os menores, brincando, ensinando e protegendo. Isso não significa que as mães sejam relapsas no cuidado com seus filhos, porém elas, muitas vezes, estão confeccionando artesanato, cuidando e organizando suas casas e contam, assim, com o auxílio dos filhos, que, inclusive, incorporam os pequenos às suas brincadeiras (Nunes, 2002).

O futebol e as brincadeiras de correr e de pegar são o entretenimento preferido das crianças da Tekoa Anhetengua, prevalecendo o coletivo, pois dificilmente percebi alguma criança brincando sozinha e separada do grupo. Elas povoam a aldeia com seus risos e conversas e "[...] essa constante presença das crianças não atrapalha o trabalho dos adultos. Pelo contrário, é-lhes de muita utilidade e parece que gostam que as crianças participem” (Nunes, 2002, p. 76). Essa constatação verificada entre os A’uwẽ-Xavante é corroborada pelas inúmeras cenas que presenciei durante meu convívio com as crianças da aldeia Mbya Guarani.

As brincadeiras de correr e de utilização do corpo para movimentos, como rodopiar, também são constantes na aldeia, assim como a formação de pirâmides de crianças, em que elas vão subindo uma em cima das outras e, depois, todas caem no chão. Quando isso acontece, riem muito e saem rolando na grama que reveste parte do campo de futebol. Entretanto, de todos os divertimentos que observei, destaco o jogo de bola.

O campo de futebol é o lugar de maior aglomeração das crianças da Tekoa Anhetengua. É nele que acontece a maioria das brincadeiras e onde prevalecem os chutes a gol, demonstrando uma grande habilidade dos kiringue com a bola. As preferências futebolísticas são visíveis através de suas falas e também das roupas que identificam seus times de preferência, destacando a dupla Gre-nal, ${ }^{9}$ mas também com menções a equipes europeias, confirmando que os indígenas estão conectados,

\footnotetext{
${ }^{9}$ Nome que identifica o maior clássico de futebol do Rio Grande do Sul, disputado entre as equipes do Grêmio Football Porto Alegrense e do Sport Clube Internacional.
} 
preparados e já vivenciando essa relação intercultural, sem que, com isso, percam a essência de sua cultura e de seu modo de vida.

\section{CONSIDERAÇÕES}

Após o convívio mais intenso com os kyringue da Tekoa Anhetengua e tendo por base as análises que identificam o modo de ser Mbya Guarani, percebo o quanto é relevante, para o professor, ter um olhar atento e questionador para as questões relativas à educação e à alteridade. Não basta saber identificar a diversidade dos povos indígenas que habitam nosso país, tampouco segregar algumas informações descontextualizadas em períodos isolados do calendário escolar. Entendo que o importante é oportunizar o diálogo e as trocas entre os diferentes, para que, a partir desse contato, possam se estabelecer relações de entendimento e respeito, que, infelizmente, ainda temos dificuldade em compreender.

Ao querer saber quem são essas crianças Mbya Guarani, com o que se ocupam, o que fazem e o que mais gostam de fazer e como se estabelece sua relação com a escola, percebi que ainda existem muitas incompreensões que não se resolvem apenas com leituras e estudos sobre a temática. Somente quando agreguei esses dois aspectos à sensibilidade em sair do meu lugar de conforto para dar a devida importância a pequenos gestos, atitudes, a um modo de vida muito diverso daquele em que estou imersa, pude perceber as semelhanças e diferenças de ser criança entre o povo Guarani e na sociedade não indígena.

Antes de serem crianças, entre os Mbya prevalece o entendimento da pessoa em sua totalidade no coletivo, mas que também possui particularidades que são respeitadas e entendidas. Ao se ocuparem das atividades da escola, dos afazeres domésticos, das brincadeiras no campo de futebol, mas também fora dele, e do cuidado afetuoso com os irmãos menores, percebe-se alegria, fazendo com que os kyringue povoem a aldeia e façam dela um lugar de aprendizados constantes, que 
têm no lado espiritual um elemento carregado de significados, muitas vezes, inexplicáveis apenas com palavras.

\section{REFERÊNCIAS}

BERGAMASCHI, M. A. Nhembo'e: enquanto o encanto permanece!: processos e práticas de escolarização nas aldeias Guarani. Tese (Doutorado em Educação) - Faculdade de Educação, Universidade Federal do Rio Grande do Sul, Porto Alegre, 2005a.

A formação da pessoa indígena: processos próprios de aprendizagem das crianças guarani e kaingang. Conferência realizada no Seminário de Educação - SEMIEDU, Universidade Federal do Mato Grosso, Cuiabá, 2012.

. Educação escolar indígena no século XX: da escola para os índios à escola específica e diferenciada. In. STEPHANOU, M.; BASTOS, M. H. C. (Org.). Histórias e memórias da educação no Brasil: século XX. Petrópolis, RJ: Vozes, 2005b. v. III, p. 401-415.

. Povos indígenas e ensino de História: a lei no 11645/2008 como caminho para a interculturalidade. In. BARROSO, V. L. M. et al. (Org.). Ensino de História: desafios contemporâneos. Porto Alegre: EST, Exclamação, ANPUH/RS, 2010. p. 151-166.

BERGAMASCHI, M. A.; MENEZES, A. L. T. Educação ameríndia: a dança e a escola Guarani. Santa Cruz do Sul, RS: EDUNISC, 2009.

BONIN, I. Educação escolar indígena e docência: princípios e normas na legislação em vigor. In: BERGAMASCHI, M. A. (Org.). Povos indígenas \& Educação. 2. ed. Porto Alegre: Mediação, 2012. p. 33-48.

BRASIL. Lei no 11.645/2008, de 10 de março de 2008. Disponível em: <http:// www.planalto.gov.br/ccivil_03/_ato2007-2010/2008/lei/111645.htm>. Acesso em: 20 dez. 2016.

FONSECA, C. Quando cada caso não é um caso - pesquisa etnográfica e educação. Revista Brasileira de Educação, n. 10, p. 58-78, 1999. 
GODOY, A. S. Características da pesquisa qualitativa: tipos fundamentais. Revista de Administração de Empresas, São Paulo, vol. 35, p. 20-29, maio/ jun. 1995.

KURROSCHI, A. R. S. Diário de campo sobre a Tekoa Anhetengua. Porto Alegre, 2012-2013, 31 p., não publicado.

LÜDKE, M.; ANDRÉ, M. Pesquisa em educação: abordagens qualitativas. São Paulo: EPU, 1986.

MEDEIROS, J. S. Escola indígena e ensino de História: um estudo em uma escola Kaingang da terra indígena Guarita/RS. Dissertação (Mestrado em Educação) - Faculdade de Educação, Universidade Federal do Rio Grande do Sul, Porto Alegre, 2012.

MELIÁ, B. Educação Guarani segundo os Guarani. In. STRECK, D. R. (Org.). Fontes da Pedagogia latino-americana. Belo Horizonte: Autêntica, 2010. p. 37-53.

MOUZER, M. V. S. Cartilha agroflorestal Mbya Guarani - saberes Yvàa. Trabalho de Conclusão de Curso em Ciências Biológicas, Instituto de Biociências, Universidade Federal do Rio Grande do Sul, Porto Alegre, 2011. NUNES, Â. No tempo e no espaço: brincadeiras das crianças A’uwẽ-Xavante. In: SILVA, A. L.; MACEDO, A. V. L. S.; NUNES, Â. (Org.). Crianças indígenas: ensaios antropológicos. São Paulo: Global, 2002. p. 64-99.

SILVA, A. L. Pequenos “xamãs": crianças indígenas, corporalidade e escolarização. In. SILVA, A. L.; MACEDO, A. V. L. S.; NUNES, A. (Org.). Crianças indígenas: ensaios antropológicos. São Paulo: Global, 2002. p. 37-63. 


\section{Capoeira Angola na escola:}

uma alternativa à formação integral dos estudantes

Viviane Malheiro Barbosa

O presente artigo propõe-se a apresentar questões referentes à dimensão educativa da Capoeira Angola e suas possibilidades no ambiente escolar com o intuito de contribuir na implementação da Lei $n^{\circ}$ 10.639/03. Pretendo articular a tradição afrodescendente e o espaço escolar a partir da visão de três mestres da Capoeira Angola entrevistados para este estudo, agregando tais conhecimentos ao meu olhar como educadora de capoeira, aluna e pedagoga. Nesse contexto, o que pretendo é expor contribuições que corroborem a importância da prática e o estudo da Capoeira Angola na escola, como possibilidade emancipatória para crianças, jovens e adultos.

A partir da minha vivência, com dezoito anos de inserção na prática da Capoeira Angola, procurei destacar a potência pedagógica dessa prática na escola e sua contribuição para o desenvolvimento do ser humano e, ainda, para a transformação e o aprimoramento de conhecimentos e de tantos outros elementos fundamentais para uma educação mais democrática, com um espaço de maior participação dos sujeitos. Para isso, tenho como fundamentos meu estudo e minha experiência 
na capoeira como também a crença de que a Capoeira Angola, como bem cultural, é rica em elementos que podem contribuir para escola e agregar-se a ela.

Realizei entrevistas ${ }^{1}$ com três mestres da arte. Minha intenção foi saber o que os mestres pensavam sobre a Capoeira Angola na escola e formas de contribuição dela para a educação dos sujeitos como um todo, discutindo brevemente sobre maneiras prováveis de acontecer essa interação. Também, pensando em sua inserção na escola, questionei que efeitos seriam produzidos na arte, já que alguns pressupostos da capoeira, como a mandinga e a malandragem, ainda hoje são vistos de forma pejorativa.

Considerar as percepções dos mestres neste estudo se apresenta como fundamental, já que são eles que possuem maior experiência e saberes sobre a capoeira. Ainda a isso se atrelam minha experiência com a Capoeira Angola e os estudos no curso de Pedagogia.

Os sujeitos escolhidos para as entrevistas foram dois mestres e uma mestra da arte da Capoeira Angola. Fiz a escolha desses entrevistados baseada no meu convívio com eles, por respeitá-los, admirá-los e por conhecer suas trajetórias e sabedoria na arte. Dois dos entrevistados foram meus mestres: a Mestra Lua foi com quem eu me iniciei na arte, e o Mestre Longevidade foi mestre da minha mestra. Optei por chamá-la de Mestra Lua pela relação que pude estabelecer com as letras do seu nome, e ao mestre, chamei-o de Longevidade, porque, além de representar

\footnotetext{
${ }^{1}$ Perguntas para os mestres: O que você reconhece como educativo na Capoeira Angola? Que fundamentos/elementos da Capoeira Angola poderiam ser importantes para a educação como um todo? Sugestões para uma articulação entre Capoeira Angola e escola. Há possibilidades? Se a capoeira entrasse na escola, fizesse parte do currículo, por exemplo, capoeira como uma disciplina, como isso seria possível? Quais possibilidades e limites da Capoeira Angola realizada no espaço escolar? Se a capoeira fosse inserida de fato na escola, ela seria descaracterizada? O que você acha da contribuição da capoeira como uma educação para a vida? O que pensa sobre isso?
} 
uma linhagem (já que foi o mestre de minha mestra), abordou várias vezes este tema durante a entrevista. Os dois têm grande influência naquilo que eu tenho como referência no meu modo de ser na capoeira.

O terceiro entrevistado, denominado aqui Mestre Tambor, conheci durante minha trajetória na capoeira em Porto Alegre. Esse Mestre também realiza trabalho com adolescentes e crianças, confeccionando tambores artesanalmente, por isso a escolha do nome.

A Capoeira Angola pode oferecer uma gama de possibilidades aos sujeitos que a praticam, por meio da musicalidade e da vivência de uma ancestralidade de matriz africana, reinventada no contexto brasileiro.

As vivências e os trabalhos que tive a oportunidade de realizar em espaços escolares me permitiram perceber que alguns praticantes que apresentavam dificuldades de aprendizagem, ao vivenciarem a capoeira, demonstravam um potencial fantástico para disponibilidade corporal, através das músicas, dos movimentos sincronizados, incluindo o entendimento mais aguçado de ser solidário ao ajudar nas tarefas e de respeito aos mais velhos, por exemplo. Isso aumentava a autoestima e a confiança desses estudantes, proporcionando ainda um ambiente de socialização. Nessa perspectiva, a Capoeira Angola adentra o ambiente escolar como uma possibilidade de transmitir aos alunos aquilo que é aprendido nesta arte de forma prática, vivenciando um conteúdo que já está na Lei $\mathrm{n}^{\circ} 10.639 / 03$, mas ainda não faz parte do cotidiano das escolas.

Trata-se da problematização de uma cultura negra de resistência que, nos currículos escolares, não existe, vivenciando uma ancestralidade africana para que os praticantes conheçam e valorizem sua história e levem esse conhecimento para sua vida.

A capoeira inserida nos currículos da escola é uma grande oportunidade de transformar o contexto escolar em benefício dos alunos e da comunidade. Essa arte traz consigo uma memória que ainda não tem voz e vez nos livros didáticos ou na sala de aula. Aliás, capoeira não 
se ensina através dos livros, contudo, dada sua história e relevância, já poderia ocupar um espaço que lhe é de direito nesses locais de aprendizagem. Em 2008, a capoeira tornou-se patrimônio cultural. Onde ela aparece na escola?

Com o objetivo de conhecer o que vem sendo produzido sobre esta temática nos anos de 2010 a 2012, realizou-se uma busca através do Lume, ${ }^{2}$ conforme consta na Tabela 1 . Ao observar a tabela, é possível verificar que apenas um (1) trabalho está vinculado ao curso de Pedagogia.

${ }^{2}$ Repositório Digital da Universidade Federal do Rio Grande do Sul. 


\begin{tabular}{|c|c|c|c|c|c|c|}
\hline$\stackrel{\circ}{\stackrel{2}{二}}$ & 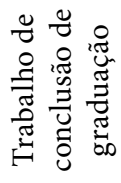 & 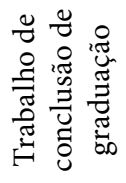 & 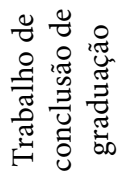 & $\stackrel{\mathscr{D}}{\mathscr{H}}$ & 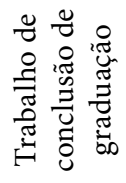 & 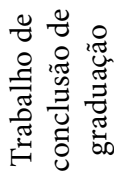 \\
\hline 是 & $\stackrel{\circ}{\stackrel{0}{0}}$ & 응 & 음 & $\stackrel{\circ}{\stackrel{i}{(}}$ & $\overline{\vec{\nu}}$ & $\stackrel{\sim}{\stackrel{\sim}{\sim}}$ \\
\hline 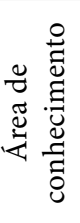 & 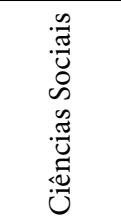 & 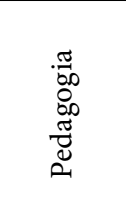 & 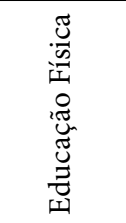 & 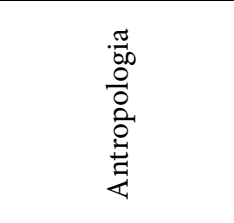 & 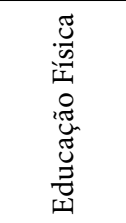 & $\underset{\Xi}{\stackrel{\Xi}{ \pm 灬}}$ \\
\hline 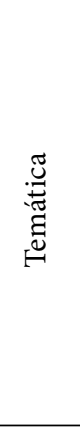 & 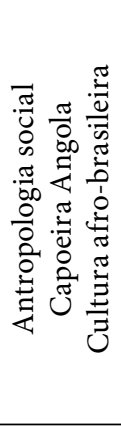 & 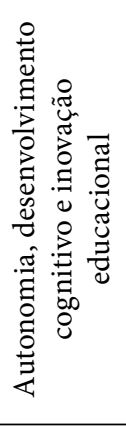 & 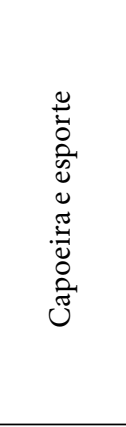 & 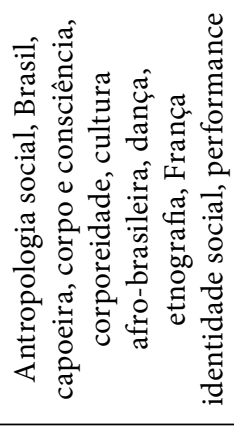 & 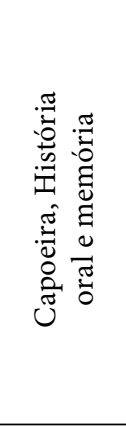 & 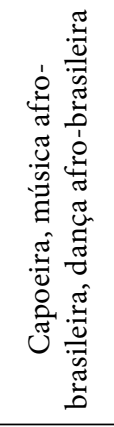 \\
\hline$\stackrel{\stackrel{0}{0}}{\stackrel{3}{Z}}$ & 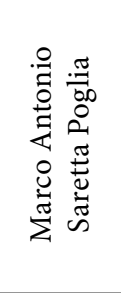 & 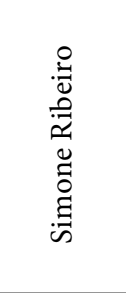 & 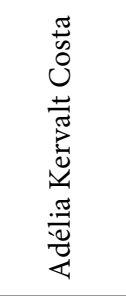 & 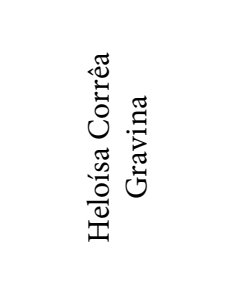 & 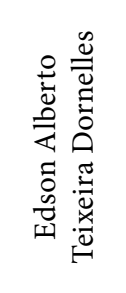 & 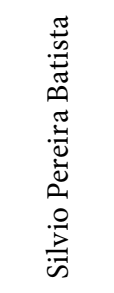 \\
\hline$\underset{\text { 诘 }}{\stackrel{O}{Z}}$ & 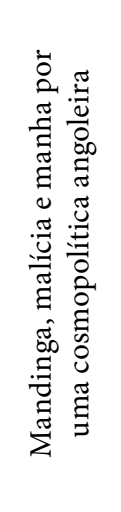 & 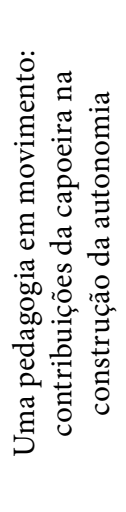 & 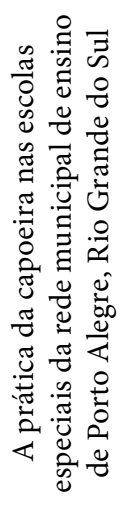 & 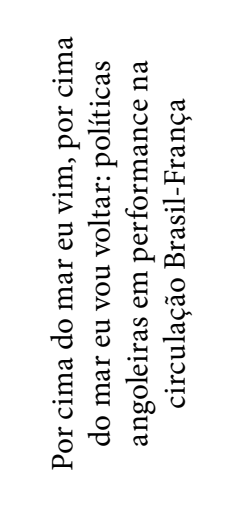 & 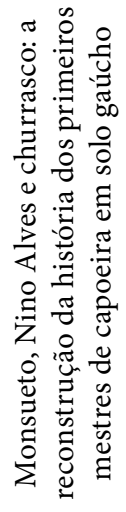 & 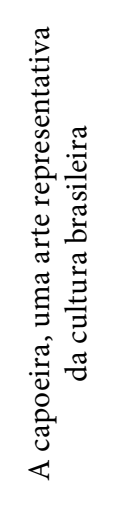 \\
\hline
\end{tabular}


Os trabalhos pesquisados possuem assuntos bastante pertinentes à valorização da capoeira, através dos diferentes olhares. Contudo, é importante mencionar que ainda necessitamos de pesquisas sobre a Capoeira Angola como aporte para o cumprimento da Lei $\mathrm{n}^{\circ}$ 10.639/03 no ambiente escolar. Isso pode indicar a pouca associação da capoeira com as abordagens educacionais.

Em linhas gerais, tal levantamento se traduz no mote de realização deste estudo, onde se pretendeu constituir argumentos sobre as possíveis colaborações da capoeira na formação integral dos sujeitos que se escolarizam, vinculando este conhecimento escolar ao da arte da capoeira, para além de uma perspectiva esportivista.

\section{CAPOEIRA ANGOLA: ALGUMAS CONSIDERAÇÕES SOBRE ESTE BEM CULTURAL \& A LEI NO 10.639/03}

A apropriação da cultura, através da Capoeira Angola, acontece por meio das histórias, dos cânticos e dos fundamentos transmitidos oralmente, dos movimentos corporais típicos da capoeira, da execução de instrumentos musicais de percussão, dos diferentes ritmos e do ritual da roda que possibilita o contato direto dos alunos com a vivência e preservação de uma arte ancestral criada pela ânsia de liberdade surgida no Brasil, por meio das lutas de trabalhadores negros escravizados. As metodologias mais conhecidas, nos grupos, consideram que, primeiramente, é importante aprender a base da ginga, depois os movimentos de defesa e, em seguida, a resposta: $o$ ataque. Nesse processo de aprendizagens, a ginga vai se construindo à medida que o jogador vai conhecendo seu corpo, descobrindo a sua dança num jogo de perguntas e respostas. Na Capoeira Angola, cada jogador tem seu jeito próprio de demonstrá-la. A malandragem vem acompanhada de um movimento que o jogador vai absorvendo conforme sua necessidade. Não depende somente da habilidade corporal, mas do entendimento aprofundado dos fundamentos e rituais da capoeira. É uma forma de brincar com o 
outro, é um “faz que vai e não vai”, é dosar bem a coragem, lidar com a opressão sem ser oprimido ou se deixar oprimir, ser aquilo que se é, sem ser manipulado, driblar situações de opressão com graça, coragem e malícia, tornando o jogo lúdico.

A capoeira ensina as pessoas a estarem atentas, de prontidão, preparadas para as dificuldades do cotidiano. $O$ capoeirista precisa procurar ter um jogo estratégico, buscando a liberdade do corpo e da expressão através da brincadeira. O ritual, a tradição, os valores e os fundamentos da capoeira nos remetem, ao contrário do que pode supor o senso comum, a uma ética de não violência, pois, ao praticar essa arte, aprendemos a respeitar o oponente partindo desse princípio. O corpo é visto como um lugar sagrado que precisa ser protegido, portanto, a Capoeira Angola sugere vê-lo de outra maneira em relação ao que propõe o senso comum, o que envolve manifestar sentimentos, estabelecer um diálogo com o mundo e expressar aquilo que se quer dizer.

Percebo que existe algo que não pode deixar de ser mencionado, além do que já foi descrito, que denomino como "espírito da capoeira": ela é viva para os que a praticam. Por mais que o capoeirista tenha domínio da arte e experiência, se ele for para o "pé do berimbau" sem respeitar seu oponente, poderá haver consequências; se o seu ego for maior que tudo que está pulsando na roda, com certeza a capoeira irá lhe ensinar uma lição. Nesse contexto, a ideia de humildade não significa submissão, mas sim amorosidade e respeito pelo outro. $\mathrm{O}$ jogo deve se desenvolver "com" o outro e não "contra" ele. Outro ritual que permeia este pensamento é o pedido de proteção ao ingressar na roda. Estamos sempre aprendendo com ela.

A capoeira tem "verdades", ao mesmo tempo em que é um jogo de "enganação". Para ser praticada, antigamente, precisava estar camuflada por meio da dança, da picardia, da molecagem e da brincadeira. Não poderia ser uma luta declarada para aqueles que a praticavam sob 
o olhar da polícia, por exemplo. Pelos estudos realizados no Dossiê do Instituto do Patrimônio Histórico e Artístico Nacional (IPHAN) ${ }^{3}$ e nos escritos de Vieira (1998), foi observado que as principais fontes dos historiadores e estudiosos da capoeira estão relacionadas aos registros nos arquivos policiais, devido à marginalização e à criminalização sofridas por aqueles que a praticavam.

Com o fim da escravidão, a capoeira é inserida no Código Penal em 1890. A partir daí, os praticantes são reprimidos com extrema violência. Os capoeiras, mesmo sendo considerados criminosos, conforme o Dossiê do IPHAN (2007, p. 17-18), “[...] tiveram uma recuperação social promovida pela 'vertente nacionalista da belle époque', que buscava defender a capoeira como ginástica brasileira". Penso que, a partir daí, inicia-se um tímido processo de reconhecimento desta arte como cultura de um povo, mas voltada para uma prática esportiva. Apesar disso, a imagem do capoeirista ainda sofria com o estigma de seus praticantes tidos como vadios e vagabundos.

No documento do IPHAN (2007, p. 23-24), há uma menção a este assunto, lembrando que

Os estudos revelam que os capoeiras não eram um
bando de vadios e vagabundos, como escreviam os jor-
nais da época, sendo grande parte deles trabalhadores.
Contudo, assim como a maioria da população sotero-
politana, os capoeiras eram trabalhadores de rua, vi-
viam de ocupações esporádicas intermitentes. Ou seja,
tinham um ritmo de trabalho bastante irregular, o que
lhes proporcionava períodos de ociosidade, entreme-

${ }^{3}$ Neste trabalho, para fins de referência, utilizei o Dossiê do IPHAN. Trata-se de um Inventário para Registro e Salvaguarda da Capoeira como Patrimônio Cultural do Brasil. É um relatório técnico, elaborado em 2007, para a instrução do processo de registro da capoeira como patrimônio cultural brasileiro. Este dossiê foi elaborado por uma equipe técnica composta por profissionais de diferentes áreas, dentre eles alguns capoeiristas. 
ados por momentos de diversão. Mesmo sendo trabalhadores, os capoeiras também podiam ser desordeiros, uma vez que muitos deles simplesmente viviam no mundo das ruas, batiam tambor, jogavam capoeira e algumas vezes até matavam. Em síntese, transgrediam os padrões e as regras da ordem pública.

É importante mencionar que as formas como a capoeira era desenvolvida não envolviam somente crimes (brigas e ataques) como relatavam as notícias dos jornais. Elas apareciam também como forma de lazer, brincadeira de rua praticada nos largos, nas praças e festas, um divertimento popular.

Em 1937 inicia-se o processo de descriminalização da capoeira. Nesse ano, Mestre Bimba recebe autorização para o funcionamento de uma escola de capoeira regional. Ele fez uma adaptação da capoeira, inserindo golpes de outras lutas, fazendo desta arte uma luta de combate direto.

Mestre Pastinha, entre outros, buscava preservar as antigas tradições, rituais e valores da Capoeira Angola, afirmando sua ancestralidade africana e dando visibilidade a essa prática. Esse mestre tornou-se, assim, um dos principais representantes de uma luta pela preservação dos rituais da Capoeira de Angola, deixando um legado que mantém viva a tradição dessa arte até os dias atuais.

A Capoeira Angola diferencia-se da regional em vários aspectos. É possível notar a diferença pelos movimentos e golpes, pela musicalidade e pelo ritual, mas principalmente pelos objetivos que cada uma delas se propõe a cumprir. A Capoeira Angola procura preservar valores culturais e históricos, voltados para uma tradição ancestral identificada com a cosmovisão africana.

Atualmente, na maioria das vezes, a capoeira tem ocupado espaços escolares apenas como atividade extraclasse, seja nas oficinas realizadas 
pelo projeto Escola Aberta $^{4}$ ou em datas comemorativas como a Semana da Consciência Negra, ${ }^{5}$ sob a forma de apresentações pontuais. Ainda é possível, portanto, vermos a folclorização dessa arte, o que a restringe às festividades. A instituição escolar demonstra não ter rompido com essa visão, talvez porque os valores histórico, social e político contidos na Capoeira Angola ainda sejam negligenciados, sem compreender essa arte como possível recurso pedagógico para a vivência de uma ancestralidade africana, própria do contexto brasileiro. A capoeira, assim como outros elementos da história e da presença negra no Brasil, foi invisibilizada em favor de uma cultura eurocêntrica.

Foi-nos apresentada uma história única que beneficiava o colonizador, que explorou a força do povo negro, estigmatizou sua imagem e ainda negou-lhe o protagonismo na história do nosso país. Isso é demonstrado claramente nos livros didáticos, com a história do negro contada do ponto de vista da escravidão, ocultando a força de um povo que lutou e que é possuidor de uma cultura que compõe as raízes do povo brasileiro.

O diálogo entre Capoeira Angola e escola vai ao encontro daquilo que está previsto nas Diretrizes curriculares nacionais para a educação das relações étnico-raciais e para o ensino da história e cultura afro-brasileira e africana e presente na Lei $\mathrm{n}^{\circ} 10.639 / 03$. A tão falada autonomia, o conhecimento da história, resgatando uma memória coletiva, e o reconhecimento dos valores das tradições culturais de nosso país podem ser vivenciados e contemplados através de um pensar mais profundo da capoeira na escola, para além do folclore e do espetáculo.

${ }^{4}$ O Programa Escola Aberta apoia a abertura, nos finais de semana, de escolas públicas localizadas em territórios de vulnerabilidade social. Viabiliza a aproximação entre escola e comunidade com atividades educativas, culturais, esportivas, de formação inicial para o trabalho aos estudantes e à população do entorno.

5 O Dia Nacional da Consciência Negra é celebrado em 20 de novembro no Brasil e é dedicado à reflexão sobre a inserção do negro na sociedade brasileira. A semana dentro da qual está esse dia recebe o nome de Semana da Consciência Negra. 
A capoeira, por ser um bem cultural, pode contribuir para que os sujeitos compreendam a cultura de resistência na história do povo negro, atuando em favor de uma memória coletiva dessa luta social. Pode contribuir também para a compreensão de valores ligados à ética, solidariedade, coletividade, humildade, sagacidade e autonomia.

A capoeira é uma valiosa expressão da cultura afro-brasileira, tanto no Brasil como no exterior. Seu registro como Patrimônio Cultural brasileiro pelo IPHAN data de 15 de julho de 2008 sob duas formas: a roda de capoeira no Livro das formas de expressão e o ofício de mestre de capoeira no Livro dos saberes. No entanto, pouco espaço foi reservado na mídia para uma discussão aprofundada a respeito desse tema. Como mencionam Oliveira e Leal (2009, p. 44), “[...] sequer foi possível conhecer, salvo de modo panorâmico, o percurso de luta que seus praticantes vivenciaram para atingir o tão aclamado reconhecimento da arte-luta como patrimônio cultural brasileiro".

Ao mesmo tempo em que é reconhecida como patrimônio, existe um paradoxo que se refere à história dos capoeiras, como mencionado anteriormente: eles sempre foram tidos como marginais e vagabundos. Cabe ressaltar que, mesmo com esse estigma, foi possível que a capoeira obtivesse reconhecimento, tornando-se um símbolo da cultura brasileira, dada a resistência que as comunidades negras puderam empreender.

A criminalização da capoeira no passado fazia parte de um conjunto de ações de desvalorização da cultura negra, pretendendo manter sua subalternidade, mas a capoeira foi uma forma que os escravizados encontraram de libertação do sistema opressor. Por isso, ainda hoje, precisa ser ocultada da história ou compreendida de forma restrita. Ela pode ser importante subsídio de libertação, não só do corpo, mas também de outras dimensões da existência. 
Há saberes relacionados com esse bem cultural que não estão apenas associados à agilidade, mas a algo que é mais profundamente vinculado à constituição do ser humano, da vivência em grupo e da história de um povo. Isso agrega diversas aprendizagens e trocas de saberes entre educandos e educadores de diferentes gerações.

Assinalo que a História do Brasil precisa ser contada de forma diferente, a fim de que se conheça outra versão dos fatos, dando valor e reconhecimento às contribuições de homens e mulheres, negros e negras. Pelo que pude observar, durante minha trajetória de Estágio Docente e em outras inserções em escolas, é notável a falta da abordagem de conteúdos relacionados ao tema nos currículos escolares. Reconhecida a necessidade de que a escola passe por reestruturação curricular, compreendo que conhecer mais profundamente a Capoeira Angola como bem cultural pode contribuir nesse processo.

A presença do racismo é evidente através da história não contada, da invisibilidade das histórias nos livros didáticos, da história única e eurocêntrica, do esquecimento relacionado à trajetória e contribuição do povo negro. A temática que ainda está ausente nas discussões, nos currículos e na sociedade brasileira surge em vários casos de forma limitada e tendenciosa. Os livros didáticos apresentam os heróis negros como figuras exóticas, distantes de qualquer realidade conhecida (a exemplo de Zumbi e Ganga Zumba), ou seja, figuras folclóricas.

\section{OS SABERES DOS MESTRES \& A CAPOEIRA ANGOLA NAS PROPOSTAS CURRICULARES: 0 CARÁTER EDUCATIVO}

Para tratar do caráter educativo da Capoeira Angola, Mestre Longevidade declara:

Eu reconheço a Capoeira Angola como educativa a partir do que antecede para que a roda aconteça, 
[...] o que antecede a roda exige que nós tenhamos uma enorme gama de saberes bem inseridos. [...] Isso é a história, a geografia, a matemática e a fisiologia que estão contidas nela. Além da musicalidade, a teatralidade, o instrumental, o cântico. [...] Pra mim [...] a experiência na capoeiragem não é só ver a questão educativa, terapêutica, e sim curativa. Então, a partir da minha trajetória, eu me curei e continuo me curando e hoje eu defendo a capoeira pra me manter aprendendo a aprender sempre. (Mestre Longevidade - trecho da entrevista realizada em maio de 2013).

Mestre Longevidade enfatiza que a capoeira é uma prática curativa, que possibilita "aprender a aprender", compreendendo isso como base fundamental. Depois aponta:

A minha preocupação começa porque ela está deixando de ser um jogo por conta de um item só de fundamento chamado finalização que não é bonito, é feio porque lesa, humilha e pode até matar. [...] É necessário que a gente estude muito e venha repetir muito as coisas e tudo que a gente repete muito dentro da capoeira é o que a gente precisa lapidar. A capoeira é um jogo, porque é necessário que a gente tenha enorme gama de saberes que temos armazenados dentro de nós. (Mestre Longevidade - trecho da entrevista realizada em maio 2013).

É possível perceber que, quando o mestre Longevidade fala sobre uma "gama de saberes", ele está se referindo a todo um aprendizado necessário ao capoeirista, o qual necessita tempo e conhecimentos pertinentes para o desenvolvimento e a participação na roda de capoeira, entendendo seu sentido. Em sua fala, ele reafirma que a capoeira é também um jogo. Ainda, evidencia que, dependendo do que 
se quer com a capoeira, no caso, utilizando um único fundamento - a "finalização" -, pode-se provocar efeitos de ordem contrária aos fundamentos da ética dessa arte, que tem como princípio a não violência.

Destaco, também, o fato de o Mestre Longevidade ter mencionado, como princípio pedagógico, a repetição necessária na prática da arte, mas vista como prática escolar tradicional e desconectada. No caso da Capoeira Angola, aponta para outra questão: o aprendente deve "repetir muito as coisas", porque existe sentido e para aprimorá-las. Sendo assim, precisa ter seu corpo manejado, treinado, freado, pois há um cuidado com o outro e respeito. O capoeirista, para atingir certo nível de destreza, necessita repetir, memorizar alguns movimentos; não somente pela repetição, mas para aprimorá-los, envoltos em um ritual e no motivo para cada situação.

Mestra Lua traz, em sua fala, a transmissão do conhecimento através da oralidade, ensinando cada aluno e respeitando suas diferenças e seu ritmo. A oralidade, como forma de ensinar, é característica da pedagogia africana. Outro destaque da fala da mestra é a importância de contar aos educandos uma nova versão da História, trazendo uma nova ótica a fim de fortalecer a "[...] autoestima e a identidade cultural do indivíduo que pratica a Capoeira Angola” (Mestra Lua - trecho do questionário realizado por e-mail em maio de 2013).

De acordo com Mestre Tambor,

[...] a gente aprende dentro da capoeira, dentro dessas coisas da tradição e busca do ser humano, que é outra coisa: o respeito, a ética, os valores que são necessários para uma relação em grupo". (Mestre Tambor - trecho da entrevista realizada em maio de 2013). 
Da mesma forma, Mestra Lua enfatiza a relevância dos valores necessários para o exercício do praticante, também voltados para a ideia do aprendizado em grupo:

A coletividade onde se pratica a (com)vivência em grupo, o fazer juntos, o aprender juntos, o cuidado com o outro, a troca de saberes, o ritmo onde cada ser tem o seu, vindo a ter tolerância às diferenças e ao tempo próprio de cada indivíduo. (Mestra Lua trecho do questionário realizado, por e-mail, em maio de 2013).

Nesse primeiro momento, já é possível perceber que os mestres são unânimes em apresentar que uma das possíveis contribuições da Capoeira Angola e seus princípios, como bem cultural, é o tensionamento na escola de uma perspectiva competitiva, antidialógica e arraigada em valores que privilegiam o individualismo, por meio da aprendizagem em roda que respeita os diferentes ritmos e formas de ser.

\section{Articulação entre Capoeira Angola e escola}

Mestre Longevidade sugere uma nova forma de ver o mundo no fazer capoeirista. Na prática da Capoeira Angola, podemos inverter a maneira de ver o mundo: de cabeça para baixo, buscando outro ângulo. Mestre Longevidade critica o fato de que professores estão deixando de aproveitar o potencial dos educandos para além do esporte, com atividades sem sentido.

Não se nega a questão da capoeira como prática física, do esporte na capoeira, dos ganhos para saúde física, e isso está presente na fala de Mestre Longevidade, mas ele salienta que não é somente isso que se precisa considerar. Sugere um olhar sobre a questão cultural, histórica e simbólica que a capoeira pode trazer e que a escola poderia 
aproveitar como potencial para enriquecer suas práticas. Para Mestre Longevidade, é de suma importância a capoeira dentro da escola.

Mestre Tambor, em sua fala, recupera uma categoria interessante: o porquê, o para quê e o como, ou seja, a não neutralidade da educação. Encontro, aqui, elementos para ressaltar também que a capoeira pode estar na escola como espetáculo ou violência, tomando um rumo que se distancia de seu sentido educativo. Sendo assim, evidenciamos a não neutralidade da capoeira.

Segundo Mestre Tambor, quem deseja se inserir nesse universo da capoeira precisa conhecer bem os mestres, as pessoas que ensinam, pois não há neutralidade nessa prática. Em seu depoimento, afirma: "Eu vejo a necessidade para saber bem o que se quer com a capoeira, o que se quer com a educação", ou seja, aponta para sua não neutralidade. E ainda complementa que é importante destacar "o que se quer passar para o jovem" e que alguns mestres buscam e potencializam a violência. Ele questiona a própria generalização que faço na pergunta envolvendo a relação entre Capoeira Angola e a escola, dizendo-me que essa relação depende do mestre, depende do quê e como, depende do porquê e para quê - sem ignorar o fato de que a capoeira não deixa de ser uma luta.

Mestra Lua considera que, para existir articulação entre Capoeira Angola e escola, é necessário que

Haja uma mudança estrutural na escola, para que ocorra uma transformação no método de ensino, visando educar o indivíduo no seu intelecto e no seu corporal, sem dicotomia. Mas de forma integral, formando seres seguros, afetivos, cidadãos conscientes e autônomos. (Mestra Lua - trecho do questionário realizado, por e-mail, em maio de 2013). 
A mestra refere-se à dicotomia corpo-mente, proveniente da lógica de produção capitalista, que está presente na escola. Por isso, não basta considerar a capoeira em sua teorização ou a capoeira apenas no corpo, mas a integralidade disso. Sendo assim, a capoeira poderia contribuir para uma visão de formação integral do sujeito, interessante na escola para a superação de uma lógica dicotômica.

\section{Capoeira e currículo escolar: possibilidades e limites da capoeira na escola e descaracterização ou não da prática no ambiente escolar}

Mestre Longevidade inicia sua fala expondo que a escola deveria aceitar a capoeira como parte do currículo, por ser um patrimônio imaterial. A arte deveria entrar na escola como um jogo, em todos os seus fundamentos. Mestre Tambor também destaca que, para a capoeira adentrar na escola, é preciso que os professores compreendam seus fundamentos, o que implica não somente trabalhar o corpo, os movimentos, mas sim entender a capoeira como forma de educação, transformação e busca de valores. Tais escolhas envolvem que esta construção se dê junto à comunidade e ao espaço escolar, mas a prática da capoeira não deve ser obrigatória.

Mestra Lua evidencia que uma maneira de a prática entrar na escola seria através da Lei $n^{\circ} 10.639 / 03$, percebida em sua pedagogia própria. Ela faz uma consideração que, nos depoimentos dos outros entrevistados, não é tão clara: ela espera que a lei contribua para que se percebam os fundamentos da cultura e da cosmovisão africanas presentes na Capoeira Angola de tal modo que esses valores e conhecimentos venham para a escola para modificar a prática educativa.

No tocante às possibilidades e aos limites, o Mestre Longevidade menciona que a capoeira já tem espaço em algumas escolas, porém 
destaca que ainda existe algum preconceito por causa da cultura racista. $\mathrm{O}$ sistema educacional deveria ter mais cuidado e apreço pela capoeira, e isso seria demonstrado se a capoeira entrasse para o currículo das escolas.

Novamente um dos mestres destaca que não deve ser somente uma prática esportiva, que deve estar associada ao jogo. Mestre Tambor relata que não podemos fazer da capoeira um espetáculo, que isso a restringiria significativamente haja vista que a considera aquém da sua possibilidade histórica e política. Ele fala que essa capoeira de espetáculo não corresponde àquilo que seria o cumprimento da Lei ${ }^{0} 10.639 / 03$. A apresentação é uma consequência, não pode ser o objetivo principal.

Mestra Lua acredita ser difícil uma reestruturação do ensino formal de modo que ele atenda a pedagogia africana, que é a pedagogia da Capoeira Angola. O limite está em compreender a escola para além da grade curricular. As possibilidades seriam o intercâmbio entre escola e capoeira, pensando de maneira interdisciplinar. Fica a questão: se a Capoeira Angola fosse inserida na escola, ela seria descaracterizada? Mestre Longevidade diz que, se a capoeira fosse tida somente como esporte, competição e espetáculo, poderia ser descaracterizada; se for assim é melhor que a capoeira não vá para o ambiente escolar. Também tratando de outros temas, igualmente sugere o "aprender a aprender".

Mestre Tambor destaca que a capoeira não deveria estar na escola "para acalmar criança rebelde". A capoeira precisa, conforme os mestres, ser vista pela escola em sua cosmovisão, em seus fundamentos e para a análise das estruturas rígidas.

Mestra Lua aponta questões que os outros mestres também abordaram, dizendo que, se a capoeira 
[...] não for trabalhada como esporte competitivo, se não estimular a violência, se o educador tiver tido um mestre e for comprometido em repassar seus saberes, se mantiver os fundamentos, a musicalidade, o jogo, a ética, a teatralidade, criatividade, enfim se a escola estiver aberta e atenta para que a pedagogia [da capoeira] seja mantida, não será descaracterizada. (Mestra Lua - trecho do questionário realizado, por e-mail, em maio de 2013).

\section{ESCOLA, CURRÍCULO $\varepsilon$ MANDINGA}

A mandinga é um componente muito importante para o capoeirista, pois é um dos elementos fundamentais para o jogo da roda de capoeira e para a roda da vida, compreendendo mais amplamente.

No contexto da capoeira, o termo mandinga designa tanto a malícia do capoeirista durante o jogo, fazendo fintas, fingindo golpes e iludindo o adversário, preparando-o para o ataque certeiro, quanto também uma certa dimensão sagrada, um vínculo do jogador da capoeira com o Axé, uma espécie de energia vital e cósmica nas religiões afro-brasileiras. (Vieira, 1998, p. 111-112).

A mandinga se opõe ao jogo violento, ela aparece como "[...] estruturante central, o componente que atribui a verdadeira identidade ao jogo da capoeira" (Vieira, 1998, p. 111). A mandinga é o tempero do jogo, a criatividade, a brincadeira, o aprender a "sorrir para o inimigo e apertar a sua mão". ${ }^{6}$ É uma maneira criativa que o capoeirista tem de lidar com as adversidades. Conforme Rego (1968 apud Vieira, 1998, p. 112),

\footnotetext{
${ }^{6}$ Trecho da música Uma vez, de autoria de Mestre Toni Vargas. Disponível em: <http:// parande.forgottenlance.com/index.php?option $=$ com_content $\&$ view=article\&id=149: uma-vez-mestre-toni-vargas $\&$ catid=30:ladainha-sarki-sozleri\&Itemid=44>. Acesso em: 25 abr. 2013.
} 
No início do século era comum o envolvimento dos capoeiristas com rituais religiosos afro-brasileiros. O substantivo "mandinga" deriva possivelmente da palavra que designa a região Mandinga na África Ocidental, banhada pelos rios Níger, Senegal e Gâmbia, uma vez que entre os africanos trazidos para o Brasil havia a concepção de que naquela região existiam excelentes feiticeiros.

Ser mandingueiro, no ambiente escolar, possibilitaria que o aluno fizesse escolhas em benefício do bem coletivo e de si próprio. Poderia, com isso, descobrir formas de aprender, de tratar os demais, percebendo que o confronto direto não é a saída para situações de conflito. A mandinga é, aqui, compreendida como forma de manifestação da inteligência e da criatividade das pessoas.

Ser malandro é ser esperto e sagaz. Aqui, o sentido não é o da trapaça, mas da criação autônoma, entendendo que isso contribuiria para o desenvolvimento do estudante integralmente. Parto do princípio de que se ele não estiver atento, presente, não irá apreender o que se desenvolve no ambiente escolar e fora dele. A esperteza não é vista, nesse contexto, como algo pejorativo, mas como recurso para o próprio crescimento do sujeito, tendo um entendimento crítico do que o cerca. $\mathrm{O}$ aluno criaria sua própria estratégia, na hora de aprender a matemática, por exemplo, sem uma forma única de fazer aquilo que é proposto. Sendo mandingueiro, ele próprio traça uma estratégia para poder realizar as tarefas.

A cultura da escola, ao longo da história dessa instituição, tem sido marcada pela dicotomia entre corpo e mente. Na compreensão presente, nas rodas de Capoeira Angola, por exemplo, no que diz respeito ao que se considera matriz africana, corpo e mente são inseparáveis. Um ponto importante diz respeito à avaliação fragmentada existente na escola, que também se fundamenta sobre bases dicotômicas que se estabelecem a partir de critérios que definem o certo e o errado, setorizando conhecimentos. 
Todos os alunos são avaliados diante de um determinado conhecimento de uma mesma forma. Há mais uma tendência à homogeneização, e, por muito, a avaliação escolar ainda é fragmentada e pontual.

$\mathrm{O}$ aprendizado da capoeira tem princípio, mas não tem fim. Essa ideia se aproxima da concepção antropológica de Paulo Freire que “[...] é marcada pela ideia que o ser humano é um ser inacabado, [...] um ser no mundo e com os outros envolvidos num processo contínuo de desenvolvimento intelectual, moral, afetivo" (Trombetta; Trombetta, 2010, p. 228). A aprendizagem não cessa em nenhum momento da vida. Perceber a relação da capoeira com o inacabamento sugere que o sujeito continue ativo diante da realidade e busque alternativas para a sua sobrevivência, não só econômica, mas política e social. Vivências que proporcionem alimento ao espírito também.

\section{Ancestralidade: presente e passado vivenciados}

Certa vez, eu estava participando de um evento de capoeira, logo que meu grupo de origem N'Zambi havia findado em Porto Alegre. A oficina era de um mestre vindo de Salvador (Bahia). Fui escolhida por ele para tocar berimbau na sua oficina, depois me aproximei e agradeci a oportunidade de ter sido chamada para compor a bateria da sua oficina. O mestre respondeu: "Não fui eu que lhe escolhi, foram os ancestrais".

Ao refletir sobre a fala do mestre e tendo algum tempo como praticante e educadora, é possível perceber que, na Capoeira Angola, os rituais estão diretamente ligados aos nossos ancestrais. "A ancestralidade, de maneira geral, é considerada relativa aos antepassados, aos antecessores, aos que passaram e aos que se encontram presentes" (Castro, 2004, p. 149). Uma mescla de valores, como pertencimento, valorização da herança histórica, tradição, oralidade, fundamentos e afirmação cultural, é vivenciada no processo educativo da Capoeira Angola, preparando as futuras gerações para manter viva a tradição e a arte da cultura da capoeira. 


\section{Roda de capoeira: lugar de tradição e aprendizagem}

A roda de capoeira é local sagrado, cercado de tradição, regras e fundamentos. É onde recebemos a energia dos nossos ancestrais, onde o capoeirista percebe o seu jogo, a sua mandinga, sua inteireza. A roda é o reflexo da vida. No jogo do capoeirista, é possível perceber como ele encara seus desafios. O errar e aprender com esse erro, o ter humildade, respeito, sabedoria, destreza, sagacidade, coragem e principalmente amorosidade.

A roda de capoeira tensiona as práticas tradicionais da escola através da circularidade, da livre expressão, da autonomia, da decisão de estabelecer um diálogo lúdico, respeitoso e guerreiro. Para a roda acontecer a contento, não pode faltar o axé, a alegria, a força vital dos capoeiristas que a compõem. A resposta do coro deve ser animada, empolgante, e o cantador deve passar sentimento, expressão daquilo que é cantado por ele. $\mathrm{O}$ jogo deve ser harmônico, conversado através de movimentos, gestos, expressões e muito "mandingado".

Na roda da capoeira, se aprende olhando também, é preciso estar atento a tudo que se passa. A postura dos mais velhos, os fundamentos, as regras existentes na roda são indicações de como o ritual acontece. É o momento de louvar aos ancestrais em que se mantém viva a tradição da capoeira no aprender e no ensinar através da brincadeira, do diálogo, da interação entre passado e presente.

\section{CONSIDERAÇÕES FINAIS}

Através da minha vivência na Capoeira Angola, dos estudos realizados durante o curso de Pedagogia e do que os mestres falaram, considero importante que a Capoeira Angola esteja no ambiente escolar. Porém é imprescindível um diálogo entre os mestres e os professores sobre os fundamentos, valores e rituais da capoeira, sendo respeitada e valorizada como tal desde uma capacidade de olhar dos professores para os mestres, reconhecendo o conhecimento que estes trazem. 
O tensionamento existente envolve entender tanto a Lei ${ }^{\circ} 10.639 / 03$ quanto o fato de que a capoeira é um dos fundamentos para a compreensão da lei. Essa tensão pode existir em razão do que a escola quer da capoeira: elemento disciplinador, de contenção. Isso é criticado pelos mestres durante as entrevistas. Também avançaríamos se a malandragem e a mandinga, fundamentos da Capoeira Angola, fossem vistas como valores a serem preservados, pois, no contexto da capoeira, esses valores são tomados como manifestação da inteligência e como forma criativa de lidar com as adversidades.

$\mathrm{O}$ que a arte se propõe com relação à autonomia, malandragem, diversificação implicará uma nova compreensão da escola. Assim, a capoeira como patrimônio está ausente da escola. E não só neste ambiente, mas fora das discussões, da mídia. Quando é mostrada, reduz-se às datas comemorativas, como espetáculo. Se pensarmos nela como bem patrimonial cultural, é de suma importância que tenhamos outro olhar, ou melhor, visibilidade, valor e reconhecimento da arte. Os mestres consideram que ainda não temos um caminho traçado para entender o verdadeiro valor da capoeira. Não adianta a capoeira ir para a escola sem manter todos os seus fundamentos, ou ser ensinada com propósitos competitivos ou violentos.

Ainda não sabemos como ocorreria a entrada da capoeira na escola, nos currículos, e se a escola estaria preparada para alterar seus métodos e receber os mestres da arte para ensinarem naquele espaço. O que supomos é que a prática da Capoeira Angola é um instrumento pedagógico muito rico para a formação das pessoas; entretanto, como a escola irá acolher a arte da capoeira é outra questão. 


\section{REFERÊNCIAS}

BRASIL. Ministério da Cultura. Dossiê inventário para registro e salvaguarda da capoeira como Patrimônio Cultural do Brasil. Brasília, DF: IPHAN, 2007. Disponível em: <http://portal.iphan.gov.br/uploads/ckfinder/arquivos/ Dossi\%C3\%AA_capoeira.pdf>. Acesso em: 6 mar. 2017. . Lei $\mathrm{n}^{\circ} 10.639$, de 9 de janeiro de 2003. Altera a Lei no 9.394, de 20 de dezembro de 1996, que estabelece as diretrizes e bases da educação nacional, para incluir no currículo oficial da rede de ensino a obrigatoriedade da temática "História e Cultura Afro-Brasileira" e dá outras providências. Diário Oficial da União, Poder Legislativo, Brasília, DF, 10 jan. 2013. Seção 1, p. 1.

CASTRO, L. V. J. Capoeira Angola: olhares e toques cruzados entre historicidade e ancestralidade. Revista Brasileira de Ciências do Esporte. Campinas, v. 25, n. 2, p. 143-158, jan. 2004. Disponível em: <http://www.rbceonline.org. br/revista/index.php/RBCE/article/view/232/234>. Acesso em: 4 mar. 2017.

OLIVEIRA, J. P.; LEAL, L. A. P. Capoeira, identidade e gênero: ensaios sobre a história social da capoeira no Brasil. Salvador: EDUFBA, 2009. Disponível em: <https://repositorio.ufba.br/ri/bitstream/ufba/126/3/Capoeira\%20identidade\%20e\%20genero.pdf >. Acesso em: 5 mar. 2017.

TROMBETTA, S.; TROMBETTA, L. C. Inacabamento. In.: STRECK, D. R.; REDIN, E.; ZITKOSKI, J. (Org.). Dicionário Paulo Freire. Belo Horizonte: Autêntica, 2010. p. 228-229.

VIEIRA, L. R. O jogo da capoeira: corpo e cultura popular no Brasil. 2. ed. Rio de Janeiro: Sprint, 1998. 
PARTE 3

FORMAÇÃO DOCENTE EM FOCO 


\section{1 \\ Pedagogia de Projetos: depoimentos de estagiárias de Pedagogia}

\section{Catarine Machado Costa}

A pesquisa realizada teve por objetivo evidenciar a compreensão das estagiárias do curso de Pedagogia da Universidade Federal do Rio Grande do Sul (UFRGS) relativamente à Pedagogia de Projetos. Seu foco central está expresso na questão: como foi vivenciada a prática de trabalho a partir da Pedagogia de Projetos por alunas-estagiárias do curso de graduação em Pedagogia da UFRGS?

A proposta foi motivada por minhas inquietações durante o Estágio Docente Obrigatório em uma escola estadual de Porto Alegre. Em certos momentos, vi-me com algumas dificuldades de colocar em prática o que aprendi durante a graduação, sobretudo no que se refere ao desenvolvimento de um trabalho interdisciplinar no qual os alunos atuem como protagonistas daquilo que estão vivenciando na sala de aula. Um trabalho em que o conteúdo aprendido pelos alunos faça sentido para eles. E é na Pedagogia de Projetos que se percebe um grande potencial para esse tipo de ensino. Ao refletir sobre tais dificuldades, questionei-me: será que essas foram dificuldades apenas minhas? Será 
que outras colegas também não passaram por isso? Tais inquietações me impulsionaram a realizar este trabalho investigativo: um estudo de caso qualitativo realizado a partir de entrevistas semiestruturadas com alunas do curso de Pedagogia da UFRGS que, assim como eu, realizaram seus estágios no segundo semestre de 2012 em escolas da rede pública de Porto Alegre.

Durante minha trajetória acadêmica, principalmente no quinto semestre do curso de Pedagogia, muitos textos foram lidos, muitas discussões foram feitas acerca do tema Pedagogia de Projetos. Ideias de autores como Josette Jolibert, em seu livro Formando crianças leitoras (1994), e Fernando Hernández, em Transgressão e mudança na educação: os projetos de trabalho (1998), colaboraram com meu trabalho e influenciaram minha concepção sobre o ensinar na sala de aula.

Baseada nos referenciais acima citados, iniciei meu estágio, procurando focar em um projeto interdisciplinar que proporcionasse uma aprendizagem significativa para quem aprende, pois penso que, quando propomos um trabalho, devemos procurar conhecer e levar em conta o contexto em que os alunos estão inseridos, elaborando um currículo que privilegie essas novas concepções de infância que hoje nos são apresentadas. De acordo com os Parâmetros curriculares nacionais (Brasil, 1997, p. 38),

O conceito de aprendizagem significativa, central na perspectiva construtivista, implica, necessariamente, $o$ trabalho simbólico de "significar" a parcela da realidade que se conhece. As aprendizagens que os alunos realizam na escola serão significativas à medida que conseguirem estabelecer relações substantivas e não arbitrárias entre os conteúdos escolares e os conhecimentos previamente construídos por eles, num processo de articulação de novos significados. 
Desenvolvi, portanto, atividades que pudessem ajudar no desenvolvimento, na socialização e numa maior integração entre a turma e o contexto social em que as crianças estavam inseridas, pois entendo ser essa uma forma de o aluno participar mais ativamente no proposto. Segundo Xavier (2001, p. 9), “[...] o estudante encontraria um propósito nos projetos de trabalho escolar, visando transformar a escola de um 'auditório' num 'laboratório', desartificializando as atividades escolares". Acredito que essa é uma estratégia muito importante em todo o processo de ensino/aprendizagem, porque, na medida em que participa da escolha do tema estudado, definindo como será realizada a pesquisa, quais materiais a turma usará, quais são as melhores estratégias, o aluno se vê como parte do trabalho, e isso torna o projeto mais interessante para ele.

As crianças têm acesso a muitas informações e não se contentam em apenas ouvir e participar de forma passiva das aulas. Elas precisam fazer parte daquilo que estão aprendendo, assim como o que elas estão aprendendo precisa fazer parte do mundo delas. Não há mais espaço para uma escola baseada apenas na transmissão de conteúdos fragmentados e descontextualizados do mundo dos alunos.

No entanto, mesmo com meus referenciais e meus conhecimentos acadêmicos sobre a Pedagogia de Projetos, enfrentei grandes dificuldades para adaptar o projeto que realizei durante meu estágio ao método tradicional de ensino da escola na qual estagiei. Muitas vezes sofria exigências que envolviam trabalhar diversos conteúdos que estavam na grade curricular da escola para serem cumpridos durante o terceiro e o quarto bimestres da turma naquele ano. Em alguns momentos, me vi perdida, sem saber como inserir um ou outro conteúdo no projeto que estávamos desenvolvendo, como, por exemplo, integrar as expressões numéricas a um trabalho sobre política e cidadania. Dificuldades como essas me fizeram trabalhar alguns conteúdos de forma paralela ao projeto e não de forma integrada, como eu gostaria. Talvez a quantidade 
de provas possa ter dificultado um pouco o trabalho, pois, na pressa de concluir os conteúdos para aplicar as provas nas datas exigidas, eu acabava desfocando, por alguns momentos, do projeto de trabalho.

Incomodou-me bastante o fato de, algumas vezes, ter que deixar o projeto de lado para ensinar os conteúdos das disciplinas exigidos pela escola, porque, em certos momentos, não consegui estabelecer relação entre eles e a temática do projeto. Talvez tal incômodo tenha sido gerado por eu pensar, inicialmente, que deveria e conseguiria introduzir todos os conteúdos da grade curricular da escola no meu projeto. A minha experiência de estágio me fez pensar nos desafios que encontrei com relação ao uso da Pedagogia de Projetos numa escola que não trabalhava dessa forma. A partir dessas inquietações, surge este trabalho de pesquisa.

\section{O CONCEITO DE PEDAGOGIA DE PROJETOS}

Aqui abordo conceitos de Pedagogia de Projetos a partir da perspectiva de autores como John Dewey (2002), Josette Jolibert (1994) e Fernando Hernández (1998), além de considerar também contribuições de Maria Luisa Xavier (2001), que me ajudaram a compreender um pouco mais sobre o tema.

Este trabalho busca compreender as possibilidades de efetivação da proposta da Pedagogia de Projetos em uma escola tradicional, a partir das dificuldades e soluções encontradas pelas professoras-estagiárias do curso de Pedagogia da Universidade Federal do Rio Grande do Sul. Para abordar tal tema, é fundamental trazer, nesta seção, as ideias de John Dewey (1859-1952), considerado o pai da Pedagogia de Projetos. Suas convicções surgiram com o movimento chamado "Escola Nova", que foi uma oposição à escola mais tradicional, baseada na transmissão pura e simples de conteúdos. Para Dewey (2002), o processo educativo deveria estar ligado à prática e não apenas à teoria. A escola deve ser um meio de socialização dos alunos, precisando estar alicerçada no real: 
A escola deve assumir a feição de uma comunidade em miniatura, ensinando situações de comunicação de umas a outras pessoas, de cooperação entre elas, e ainda, estar conectada com a vida social em geral, com o trabalho de todas as demais instituições: a família, os centros de recreação e trabalho, as organizações da vida cívica, religiosa, econômica, política. (Dewey, 2002, p. 8)

Ele aponta a educação escolar como algo que deve refletir a vida cotidiana dos alunos, uma vez que a escola também faz parte da vida dos discentes.

Nessa mesma perspectiva, Xavier (2001) assinala que a Pedagogia de Projetos tem como objetivo uma educação globalizada que leva em conta os saberes não escolares do aluno, os seus interesses, e é capaz de abarcar as disciplinas, dando um significado para elas. Afirma, ainda, que a Pedagogia de Projetos é uma forma tradicional de integração curricular, que busca estabelecer relações entre as diversas áreas do conhecimento e dessas áreas de conhecimento com o cotidiano de quem aprende, tornando a educação mais significativa, pois o aluno consegue ver sentido naquilo que está aprendendo.

Segundo Hernández (1998), os Projetos de Trabalho são uma proposta que visa a estabelecer relações entre os conhecimentos científicos da escola e os saberes de fora da sala de aula, tornando os alunos protagonistas de sua aprendizagem, tendo o professor como um mediador, e não o centro do processo. $\mathrm{O}$ autor ainda argumenta:

É possível organizar um currículo escolar não por disciplinas acadêmicas, mas por temas e problemas nos quais os estudantes se sentissem envolvidos, aprendessem a pesquisar para depois aprender a selecioná-las, ordená-las, interpretá-las e tornar público o processo seguido. (Hernández, 1998, p. 19). 
Hernández entende que o processo educativo deve ampliar os horizontes de conhecimentos de quem aprende. Não basta apenas desenvolver um projeto baseado no contexto do aluno, é necessário trazer o novo, o desconhecido para a sala de aula. $\mathrm{O}$ autor refere-se da seguinte forma ao trabalho que parte somente do interesse e do contexto dos alunos: "Seguir esse caminho ao pé da letra significaria reduzir suas possibilidades como apêndices, limitar suas aprendizagens do que 'não sabem' que lhes possa interessar [...]" (Hernández, 1998, p. 27). Para ele, a escola precisa ir além do mundo com que os alunos estão acostumados. Ainda sobre a ampliação dos conhecimentos dos alunos, o autor aponta uma nova organização da escola, um intercâmbio escolar, que não tenha apenas um professor como fonte de informação. Desse modo, propõe:

Os Projetos de Trabalho e a visão educativa à qual se vinculam convidam a repensar a natureza da Escola e do trabalho escolar, pois requerem uma organização da classe mais complexa, uma maior compreensão das matérias e dos temas em que os alunos trabalham, o que faz com que o docente atue mais como guia do que como autoridade. (Hernández, 1998, p. 73)

Nessa direção, Hernández (1998, p. 23-24) afirma ainda que “[...] a função da escola não é encher a cabeça dos alunos de conteúdos, mas contribuir para formá-los para a cidadania e oferecer-lhes, como já se indicou, elementos para que tenham possibilidades de construir sua própria história".

Ao se referir à Pedagogia de Projetos, Josette Jolibert (1994) indica a importância da autonomia do aluno dentro do projeto desenvolvido, pois ele precisa estar envolvido e engajado durante o processo. Para a autora,

Na maior parte do tempo, a pedagogia tradicional, e até a pedagogia dita renovada, envolve o ensino: a atividade essencial é realizada pelo professor, e às crianças só 
cabe "entender", "responder" ou "executar" as tarefas imaginadas por ele. Nenhuma exigência ligada a uma situação real: estamos no campo do fazer de conta, ou em atividades nas quais aprender é a meta e não o meio. (Jolibert, 1994, p. 25).

Jolibert utiliza o termo "cooperativa" quando se refere à organização do trabalho em sala de aula, onde as tarefas e o andamento das atividades são geradas pelos próprios alunos. "É vivendo em um meio sobre o qual podemos agir que são criadas condições favoráveis ao aprendizado" (Jolibert, 1994, p. 12). A Pedagogia de Projetos propõe uma concepção na qual o aluno atua como agente ativo do processo educativo e o professor, como um facilitador desse mesmo processo.

O trabalho com projetos vai muito além de partir do contexto dos alunos e do que eles têm como interesse. É necessário oferecer um ambiente escolar que estimule o aluno a compreender o novo, a instigar suas curiosidades, a elaborar projetos que partam de situações-problema. É função do professor oferecer possibilidades novas, às quais, muitas vezes, os estudantes não teriam acesso fora da escola.

Outra questão fundamental é que os projetos não precisam dar conta de todos os conteúdos escolares. Não podemos, em busca de um ensino globalizado, ficar presos aos conteúdos, porque eles estão à disposição do grupo e entram no projeto conforme sua relação com o tema proposto. Alguns conteúdos, quando exigidos pela grade curricular da escola, podem aparecer em projetos paralelos ou até em atividades pontuais.

Nesse âmbito, Jolibert (1994) aponta que, dentro da mesma sala de aula, pode haver mais de um projeto andando paralelamente, o que mostra que o planejamento dentro da Pedagogia de Projetos é algo bastante flexível e não precisa dar conta de todos os conteúdos ao mesmo tempo. Ao refletir sobre esse caráter flexível referido pela autora, deparo-me com o que vivenciei durante o meu estágio docente e que me levou a esta pesquisa, que foi o fato de não conseguir "encaixar" 
algum conteúdo exigido pela escola dentro do meu projeto, o que me deixou bastante frustrada em alguns momentos.

Penso que desenvolver mais de um projeto possa facilitar no que diz respeito a dar conta dos variados interesses da turma, conseguir articular mais conteúdos com a temática a ser desenvolvida, tornando o ensino o mais interdisciplinar possível e, assim, não correr o risco de tornar o projeto algo maçante, cansativo não só para os alunos, mas também para o professor.

Percebi que, durante o estágio, me mantive presa a uma interpretação equivocada e fixa de Pedagogia de Projetos, preocupada em "encaixar" todos os conteúdos no projeto que desenvolvi. Acredito que eu possa atribuir isso à minha falta de experiência em sala de aula e ao pouco conhecimento teórico sobre a Pedagogia de Projetos.

\section{QUE ENTENDEM AS ESTAGIÁRIAS ENTREVISTADAS SOBRE A PEDAGOGIA DE PROJETOS}

Tratarei, aqui, sobre o que as alunas-estagiárias que foram por mim entrevistadas entendem por Pedagogia de Projetos. Essa análise se deu a partir do que elas apontaram, durante as entrevistas, a respeito do conceito da proposta de ensino acima citada e de como foram as escolhas das temáticas desenvolvidas em seus planejamentos pedagógicos durante o período de estágio. Seleciono, para esta seção, duas respostas acerca do tema Pedagogia de Projetos. Vale lembrar que os nomes das entrevistadas são fictícios.

Mirela: Pelas leituras e poucas experiências que eu tive, a Pedagogia de Projetos, tenta integrar o interesse da turma e o objetivo com aquela turma. Agregar todos esses interesses a um ensino, uma aprendizagem para além do conteúdo. (11/4/2013, grifos meus). 
Uma questão importante que aparece no relato da estagiária é "uma aprendizagem para além do conteúdo". Tal relato mostra certa insatisfação com um ensino fragmentado, alicerçado apenas nos conteúdos curriculares. Nesse sentido, Mirela aponta a Pedagogia de Projetos como algo capaz de dar conta dos ensinos disciplinares científicos e, como ela mesma menciona, capaz de ir além desses ensinamentos, tornando o aprendizado mais ligado ao real. Quando menciono a expressão "ligado ao real", refiro-me ao fato de os conteúdos estarem relacionados com as práticas do dia a dia, como trazer questões matemáticas com o objetivo de solucionar assuntos que surjam de dúvidas reais dos alunos, por exemplo.

A outra estagiária entrevistada, Valéria, também entende o trabalho com projetos como algo que vem de um interesse do aluno, mas enfatiza a interdisciplinaridade como algo fundamental para tal metodologia.

Na minha opinião, significa, primeiramente... Eu não consigo pensar em Pedagogia de Projetos sem pensar em interdisciplinaridade, a primeira coisa que me vem à cabeça é a integração das disciplinas, é a não fragmentação dos conteúdos. (18/4/2013, grifos meus).

Valéria ainda salienta:

Eu também acredito que é importante trabalhar os conteúdos tradicionais, mas pra mim, na Pedagogia de Projetos, é possível aliar essas duas coisas, trabalhar os conteúdos da escola, que são necessários, são necessários pra vida, pro mundo, mas também trabalhar os interesses dos alunos e os conteúdos de modo contextualizado, contemplando, assim, os interesses deles assim como os interesses do currículo da escola. (18/4/2013, grifos meus). 
Concordo com Valéria quando fala que os conteúdos curriculares são importantes e que a Pedagogia de Projetos alia o ensino desses conteúdos do currículo da escola com os conteúdos que não fazem parte de uma grade curricular. Mas compreendo que o sistema de ensino que se apresenta em grande parte das escolas dificulta o ensino interdisciplinar, uma vez que todo o currículo é separado por disciplinas, cada uma tendo seu dia e horário preestabelecidos.

Ao fazer uma análise do que dizem as estagiárias sobre suas representações acerca da Pedagogia de Projetos, infiro que todas as entrevistadas entendem essa concepção de ensino como uma proposta que se dá a partir de uma educação alicerçada no cotidiano dos alunos, naquilo que se apresenta como sendo algo que surja das vontades de quem está aprendendo, mas sem deixar de considerar os interesses do professor e os objetivos que este tem para determinada turma. Dessa forma se dá um ensino que promove a autonomia dos alunos, fazendo-os participantes ativos no processo educativo.

Entretanto a atuação ativa do aluno na perspectiva do trabalho com projetos não se limita à escolha do tema que será pesquisado. Tornar ativa a participação do estudante é também torná-lo pesquisador do que se busca descobrir, incentivá-lo a definir quais estratégias serão usadas, os materiais utilizados. Enfim, envolvê-lo do início ao fim do processo.

Outra questão apresentada pelas estagiárias é o fato de a interdisciplinaridade estar relacionada à Pedagogia de Projetos. Percebeu-se, com as respostas, uma certa crítica a um sistema de ensino focado nas disciplinas que não se relacionam entre si e à grande lista de conteúdos das escolas. 


\section{OS MAIORES DESAFIOS DAS ENTREVISTADAS}

\section{AO IMPLEMENTAR O TRABALHO COM A PEDAGOGIA \\ DE PROJETOS DURANTE SEUS ESTÁGIOS}

Nesta seção, apresentarei o que as entrevistadas relataram quando foram questionadas sobre suas experiências ao realizar seu trabalho com a Pedagogia de Projetos nas escolas em que fizeram seus estágios docentes obrigatórios. Uma questão bastante recorrente em todas as entrevistas foi a dificuldade de articular os conteúdos presentes nas grades curriculares das escolas com os projetos que elas desenvolveram.

Questionei as alunas sobre suas vivências nas práticas da Pedagogia de Projetos em seus estágios obrigatórios, se tiveram dificuldades e quais foram estas dificuldades. Mirela, que estagiou em uma turma de quinto ano do Ensino Fundamental, expôs que seu maior desafio foi fazer os alunos compreenderem sua proposta de trabalho, na qual os conteúdos não eram desenvolvidos de maneira separada, cada um dentro de sua disciplina correspondente, mas de maneira articulada com as diversas áreas do conhecimento.

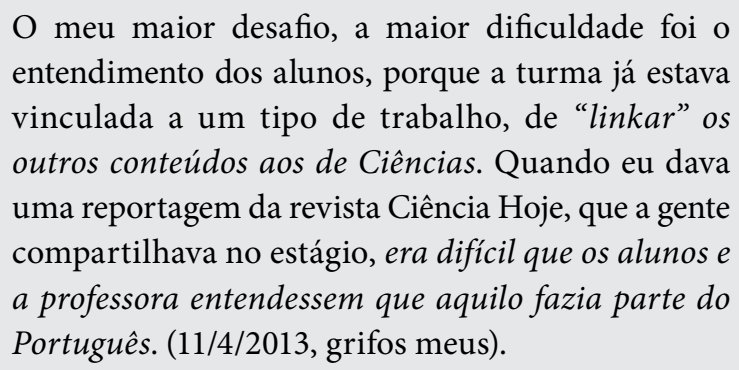

Já Aline, que fez seus estágio na Educação de Jovens e Adultos (EJA), comenta que: 
No início foi bem complicado, porque eu sabia o que ia trabalhar com elas, só que eu não conseguia articular outras áreas do conhecimento com aquilo ali, sabe? Principalmente a Matemática. (4/4/2013).

Se a grande dificuldade de Mirela foi fazer com que os alunos compreendessem e aceitassem a Pedagogia de Projetos como uma proposta mais integradora, interdisciplinar, Aline indica que seu maior desafio foi articular os conteúdos que a escola exigia ao seu projeto. Esta estagiária ainda aponta o fato de os conteúdos matemáticos terem sido aqueles em que ela encontrou maiores dificuldades. Ela atribuiu esse obstáculo à sua falta de experiência e apontou que o apoio da professora titular foi muito importante, pois ambas realizavam o planejamentos juntas, e ela podia contar com a ajuda de uma professora mais experiente.

Valéria, que estagiou em uma turma de $5^{\circ}$ ano, com relação às suas dificuldades, trouxe o seguinte relato:

A minha maior dificuldade foi exatamente essa, achar conexões de alguns conteúdos das diversas áreas do conhecimento com o meu projeto. Penso também que alguns projetos facilitam mais essa adaptação do que outros. (18/4/2013).

Creio que é natural que uma disciplina seja mais fácil ou mais difícil de encaixar nos projetos desenvolvidos. Acredito que isso depende de diferentes fatores: do tema do projeto escolhido, do domínio do conteúdo, da experiência em organizar as atividades pedagógicas, da criatividade, etc. Por isso, considero importante quando Jolibert (1994) fala que é possível desenvolver trabalhos paralelos na sala de aula. E foi o que Aline e Mirela fizeram. Isso possibilita que se contemplem as mais variadas disciplinas e seus conteúdos dentro das variadas propostas de trabalho. 
As falas das estagiárias, ao demonstrarem incômodo em não conseguir incluir as diversas áreas do conhecimento dentro dos seus projetos, evidenciam uma forma de ver o uso de projetos e um ensino interdisciplinar como uma camisa de força, devendo sempre usar os conteúdos dentro dos temas que estão desenvolvendo.

\section{MINHAS CONSIDERAÇÕES SOBRE 0 ESTUDO}

Ao trazer as considerações finais deste estudo, retomo o problema de pesquisa: como foi vivenciada a prática de trabalho a partir da Pedagogia de Projetos por alunas-estagiárias do curso de graduação em Pedagogia (UFRGS)? O estudo mostrou que as estagiárias entendem a Pedagogia de Projetos como uma estratégia interdisciplinar, em que os conteúdos devem ser estudados dentro dos projetos que estão sendo desenvolvidos, além de os temas surgirem dos interesses dos alunos e partirem de suas realidades.

Tais concepções ficaram claras ao analisar como se deram seus planejamentos pedagógicos: seus temas de projetos foram escolhidos a partir do que o aluno gostaria de aprender, daquilo que estava fazendo parte do dia a dia deles. Além disso, revelaram sua preocupação em elaborar projetos que contemplassem os diversos conteúdos da grade curricular da escola. Percebe-se que até aí não há nada de novo, as alunas repetiram aquilo que se tem dito e ouvido em muitas experiências com a proposta.

Como consequência desse entendimento das estagiárias, elas apontam como a maior dificuldade o fato de não terem conseguido dar conta de todos os conteúdos dentro de um mesmo projeto de trabalho, pois, de acordo com elas, trabalhar com a Pedagogia de Projetos pressupõe um trabalho interdisciplinar globalizado e que todos os conteúdos precisam ser adaptados ao tema que está sendo desenvolvido. 
Ao refletir sobre essa pesquisa e os estudos para poder realizá-la, percebi o quanto eu também estava equivocada quanto ao conceito de Pedagogia de Projetos, uma vez que minhas opiniões eram semelhantes às opiniões das alunas entrevistadas. Acreditava que deveríamos partir apenas dos interesses dos alunos, do ambiente em que eles estavam inseridos e que todos os conteúdos deveriam ser estudados dentro de um único projeto.

Hoje entendo que a Pedagogia de Projetos não exclui os conteúdos escolares, pois estes são importantes para o desenvolvimento de aprendizagens específicas e, para alguns grupos sociais, só são possíveis no espaço da escola. A proposta pedagógica traz uma concepção de ensino que agrega esses ensinamentos científicos aos conhecimentos que os alunos já trazem consigo, valorizando seus saberes, tornando a aprendizagem algo mais interessante. Um projeto deve considerar o contexto em que $\mathrm{o}$ aluno vive e aquilo que ele conhece, mas a professora tem a função de também trazer para dentro da sala de aula oportunidades para que ele conheça coisas novas e, principalmente, aprofunde os conhecimentos que acredita ter e invista neles. Uma professora engajada busca oferecer acesso a temáticas, materiais e conteúdos a que, muitas vezes, os alunos não podem ter acesso, cabendo à escola oferecer essa oportunidade. Os conhecimentos de âmbito social, cultural e político favorecem a formação de sujeitos socialmente mais engajados, mais críticos. Além disso, os projetos não podem se transformar em armadilhas pedagógicas na busca de um currículo mais globalizado.

Entendo que um projeto é carregado de intencionalidades, deve ter objetivos claros. A Pedagogia de Projetos tira o aluno da passividade, fazendo-o participar de forma mais ativa do processo educativo. Além disso, o tema não deve ser definido apenas pelos alunos, mas junto com eles, em forma de um problema de pesquisa em torno do qual tudo o grupo participe, a fim de buscar respostas possíveis, o que envolve participação dos estudantes, dos professores e dos gestores da escola. 
Se um tema de projeto for definido apenas pelo professor, o aluno não estará participando de um projeto dentro da perspectiva teórica aqui defendida; estará apenas realizando tarefas predeterminadas pelo professor em torno de um tema comum.

Se considerarmos os conceitos de Pedagogia de Projetos apontados neste trabalho, nem eu, nem as estagiárias por mim entrevistadas realizamos um trabalho que estivesse alicerçado de fato ou inteiramente na Pedagogia de Projetos, como pensava inicialmente. Afinal, tal estratégia pedagógica prevê um trabalho flexível, ao qual os professores não se sintam presos, um trabalho que possibilite novas experiências para seus alunos, não apenas focando no que eles já vivem ou conhecem. Além disso, supõe a elaboração de uma pergunta/problema que todo o grupo busca resolver e a participação dos alunos de forma ativa.

É importante destacar que essa participação ativa é entendida como a possibilidade de o aluno pensar pedagogicamente, trazendo sugestão de materiais, atividades, visitas, leituras, sites de pesquisa, organizando o cantinho do projeto. Mediante a participação pela Pedagogia de Projetos, é possível cumprir a função escolar de formar cidadãos críticos, participativos, cooperativos e engajados.

\section{REFERENNCIAS}

ALMEIDA, M. E. B. Como se trabalha com projetos (Entrevista). Revista TV Escola, Brasília, n. 22, mar./abr. 2002. Disponível em: <http://www.virtual. ufc.br/cursouca/modulo_4_projetos/conteudo/unidade_1/Eixo1-Texto14. pdf >. Acesso em: 6 mar. 2017.

BRASIL. Ministério da Educação e do Desporto. Secretaria de Educação Fundamental. Parâmetros curriculares nacionais: introdução. Brasília: MEC, 1997. v. 1.

DEWEY, J. Vida e educação. São Paulo: Melhoramentos, 2002. 
HERNÁNDEZ, F. Transgressão e mudança na educação: os projetos de trabalho. Porto Alegre: Artmed, 1998.

JOLIBERT, J. Formando crianças leitoras. Porto Alegre: Artes Médicas, 1994. XAVIER, M. L. M. Planejamento do ensino na escolarização inicial: globalização, interdisciplinaridade e integração curricular. In: XAVIER, M. L. M.; DALLA ZEN, M. I. H. (Org.). Planejamento em destaque: análises menos convencionais. Porto Alegre: Mediação, 2001. p. 1-13. (Caderno de Educação Básica, 5). 


\section{0 que ensinam os Estágios de Docência?} A formação docente no Curso de Pedagogia da UFRGS

Lidiane da Silva Machado

Este artigo constituiu-se a partir de uma pesquisa sobre os Estágios de Docência do Curso de Pedagogia da Universidade Federal do Rio Grande do Sul (UFRGS). O Estágio de Docência do Curso de Pedagogia é uma etapa relevante na formação acadêmica, é o encontro efetivo com a prática, é quando a aluna ${ }^{1}$ se percebe aluna-estagiária-professora. Durante este período, é possível sentir-se professora e, com isso, aprender com e na prática, buscar, retomar e utilizar os conhecimentos teóricos que foram constituídos até o momento. Para mim, o Estágio de Docência foi um momento de aprendizagem, mas também de muitas dúvidas. Esse momento me suscitou investigar sobre a formação que estamos recebendo no curso. O que será que minhas colegas sentiram? Quais necessidades práticas e/ou teóricas tiveram?

\footnotetext{
${ }^{1}$ Neste texto, será usada a palavra aluna em função da predominância do sexo feminino no curso de pedagogia.
} 
A partir dessas inquietações, elegi as seguintes questões investigativas: como as alunas da oitava etapa do curso de Pedagogia da UFRGS percebem o Estágio de Docência na sua formação? Quais as aprendizagens produzidas? Quais as dificuldades enfrentadas? Como estas alunas analisam as propostas de funcionamento das disciplinas de Seminário da Prática Docente oferecidas na sétima etapa e vinculadas ao Estágio de Docência? Como se posicionam sobre a proposta de funcionamento dos Estágios de Docência? Ao considerar essas questões, o presente estudo teve como objetivo problematizar a formação docente para a Educação Infantil e Anos Iniciais do Ensino Fundamental (crianças, jovens e adultos) ao analisar as propostas dos Estágios de Docência oferecidas na sétima etapa do curso.

Este trabalho, de caráter qualitativo, envolveu análise de conteúdo ${ }^{2}$ de relatórios de estágio de quatro alunas do curso de Pedagogia, que realizaram seus estágios nas diferentes modalidades oferecidas. ${ }^{3}$ Ainda tratei como dado relevante a formação pregressa ao curso de Pedagogia dessas alunas. Faço, aqui, uma breve apresentação das quatro alunas que colaboraram neste estudo. A1-EI ${ }^{4}$ iniciou o curso de Pedagogia na UFRGS no segundo semestre de 2009, realizou o Estágio de Docência na mesma escola e turma em que atuava no momento, uma turma de Jardim (com crianças de 4 a 6 anos). A2-EI também iniciou o curso de Pedagogia da UFRGS no segundo semestre de 2009, realizou seu Estágio de Docência em uma turma de Jardim,

${ }^{2}$ Conforme Lüdke e André (1986).

${ }^{3} \mathrm{Na}$ sétima etapa do curso de Pedagogia, há possibilidade de optar por uma das seguintes modalidades de estágio: Estágio de Docência 0 a 3 anos; Estágio de Docência 4 a 7 anos; Estágio de Docência 6 a 10 anos; e Estágio de Docência em Educação de Jovens e Adultos (EJA).

${ }^{4}$ Para manter o sigilo, adoto A1, A2, A3 e A4 ao me referir às entrevistadas. Também, acrescento as iniciais do nível de ensino afim ao estágio realizado pela aluna, ou seja, EI se refere à Educação Infantil, AI se refere aos Anos Iniciais do Ensino Fundamental e EJA, à Educação de Jovens e Adultos. Por exemplo, A1-EI significa que a entrevistada realizou seu Estágio de Docência em uma classe de Educação Infantil. 
em uma escola indicada pela sua orientadora. A3-AI iniciou o curso de Pedagogia em outra universidade em 2002, mas não o concluiu; no segundo semestre de 2007, iniciou a Pedagogia na UFRGS e, posteriormente, realizou seu Estágio de Docência na turma em que atuava em uma escola municipal, naquele momento era professora de um $3^{\circ}$ ano. A4-EJA iniciou o curso de Pedagogia na UFRGS no primeiro semestre de 2008 e realizou seu Estágio de Docência em uma turma dos Anos Iniciais da EJA, em uma escola municipal.

Além da análise dos documentos, foram necessárias entrevistas semiestruturadas com as autoras dos relatórios para complementação dos dados, esclarecendo as dúvidas surgidas durante a leitura do material. Todas as quatro alunas assinaram o termo de consentimento informado, autorizando, dessa forma, o uso de trechos dos relatórios e das entrevistas neste trabalho.

Para a realização da pesquisa, precisei analisar documentos do curso para melhor entender como foi elaborada a alteração curricular que resultou na proposta em vigência desde 2007, e, em especial, a proposta das modalidades de Estágio de Docência em um grupo de disciplinas alternativas obrigatórias oferecidas na sétima etapa do Curso. Foram consultados documentos legais, como a Lei de Diretrizes e Bases da Educação Nacional no 9.394, de 1996, e a Resolução do Conselho Nacional de Educação (CNE/CP) no 1, de 15 de maio de 2006, que institui as diretrizes curriculares nacionais para o curso de graduação em Pedagogia, licenciatura.

Para os referenciais de análise recorri às posições de Philippe Perrenoud (2002a) que me auxiliaram a compreender que a formação deve antecipar as transformações, ou seja, "[...] para fazer as práticas evoluírem, é importante descrever as condições e as limitações do trabalho real dos professores” (p. 17). Para o autor, a formação exige, além do simples “domínio de saberes”, o domínio de competências, para que 
os professores consigam trabalhar diante das dificuldades encontradas em sala de aula. Ele defende, ainda, a importância da articulação entre teoria e prática, para isso se faz necessário que os próprios formadores realizem esta articulação e, também, que haja uma alternância entre os períodos de aula e de estágio. Perrenoud (2002a) acredita que, com isso, poderiam ser criadas as "unidades de formação", as quais seriam concebidas especificamente para esta articulação entre teoria e prática.

As proposições de Maurice Tardif (2007) auxiliaram-me nas análises referentes aos saberes docentes, os quais o autor explicita e diferencia: os saberes da formação profissional, que são os transmitidos nas instituições de formação superior, também chamados de saberes pedagógicos; os saberes disciplinares, que são aqueles "saberes sociais definidos e selecionados pela instituição universitária” (Tardif, 2007, p. 38); os saberes curriculares, que são aqueles selecionados pelos programas escolares, os planos de ensino; e os saberes experienciais, que são adquiridos e desenvolvidos pelos professores no seu trabalho cotidiano. Essas categorias ajudaram-me a analisar os dados coletados nas entrevistas e nos relatórios de estágio.

\section{FORMAÇÃO DOCENTE}

A formação docente mobiliza diferentes tipos de saberes. A aluna em formação depara-se com teorias que, em sua maioria, já estão constituídas há algum tempo e demandam compreensão. A meu ver, esta é uma parte importante da formação. Tardif (2007, p. 36) classifica esses saberes como saberes da formação profissional, "o conjunto de saberes transmitidos pelas instituições de formação de professores", e os saberes disciplinares, que "são saberes que correspondem aos diversos campos do conhecimento, aos saberes de que dispõe a nossa sociedade, tais como se encontram hoje integrados nas universidades, sob a forma de disciplinas" (Tardif, 2007, p. 38). Além desses saberes, a aluna em formação deve relacionar os saberes teóricos com os práticos. Concordo com 
Perrenoud (2002a) quando defende que esta articulação entre teoria e prática deva partir também dos próprios formadores, não dependendo apenas das habilidades e capacidades das alunas em formação.

Acredito que a formação supõe algo maior do que o domínio de saberes, ou seja, é necessário o saber, mas também, o saber ensinar. Perrenoud (2002a) aborda o domínio de competências, para que os professores consigam trabalhar diante das dificuldades encontradas em sala de aula. Afim a esta posição, Tardif (2007) entende que, através do enfrentamento das dificuldades práticas, as/os professoras/es constituem saberes próprios, os saberes experienciais que são adquiridos e desenvolvidos durante o trabalho cotidiano. Nesse sentido, corroboro com Perrenoud (2002b, p. 17) quando aborda que

[...] a formação de bons principiantes tem a ver, acima de tudo, com a formação de pessoas capazes de evoluir, de aprender de acordo com a experiência, refletindo sobre o que gostariam de fazer, sobre o que realmente fizeram e sobre os resultados de tudo isso.

As Práticas de Ensino e o Estágio de Docência do Curso de Pedagogia proporcionam que as alunas adentrem no ambiente escolar, demandando que realizem a conexão entre o que aprenderam durante o curso e os seus objetivos pedagógicos, de acordo com o contexto escolar em que se inseriram. Além disso, é comum que as alunas estagiárias sintam insegurança e, também, receio de apostar em determinadas propostas didáticas. Partilho da opinião de Perrenoud (2002b, p. 19), que explicita as características de professores principiantes:

O estresse, a angústia, diversos medos e mesmo os momentos de pânico assumem enorme importância, mas eles diminuirão com a experiência e com a confiança. $\mathrm{O}$ principiante precisa de muita energia, de muito tempo e de muita concentração para resolver problemas que o profissional experiente soluciona de forma rotineira [...]. 
Penso que, em função dessas angústias, as experiências de práticas docentes deveriam ser distribuídas e mais intensas ao longo do curso, oportunizando às estudantes a prática reflexiva, relevante à autoformação. Perrenoud (2002b, p. 20) explica que "A reflexão sobre os problemas profissionais só pode ser treinada caso refira-se constantemente às práticas. Se elas constituem um futuro longínquo e abstrato, como podem se transformar na matéria-prima do trabalho de formação?”.

\section{Atuação docente: orientações no Estágio de Docência}

Nas modalidades de Estágio de Docência, coordenadas por professoras orientadoras, há mais de uma professora para atendimento das alunas estagiárias. São formados grupos de orientações, sendo o número de alunas por grupo variável, conforme o número de matriculadas. A professora orientadora acompanha o grupo de alunas estagiárias durante todo o período do estágio, orientando seus planejamentos e realizando visitas às salas de aula, locais da prática docente. As orientações de estágio ocorrem nas disciplinas denominadas Seminário da Prática Docente.

No Quadro 1 constam informações relativas ao segundo semestre de 2012, período em que as alunas entrevistadas realizaram seus Estágios de Docência.

Quadro 1 - Estágios de Docência no 2º semestre de 2012

\begin{tabular}{|c|c|c|}
\hline Disciplinas & $\begin{array}{c}\text { Professoras } \\
\text { orientadoras }\end{array}$ & $\begin{array}{c}\text { Alunas } \\
\text { estagiárias }\end{array}$ \\
\hline $\begin{array}{c}\text { Seminário de Prática } \\
\text { Docente - 0 a 7 anos }\end{array}$ & 02 & 04 \\
\hline $\begin{array}{c}\text { Seminário de Prática } \\
\text { Docente - 6 a 10 anos }\end{array}$ & 03 & 05 \\
\hline $\begin{array}{c}\text { Seminário de Prática } \\
\text { Docente em EJA }\end{array}$ & 01 & 26 \\
\hline Total & 06 & 17 \\
\hline
\end{tabular}

Fonte - Dados fornecidos pelas professoras orientadoras das disciplinas 
As entrevistadas manifestaram suas impressões sobre os procedimentos destas disciplinas de Seminário, instigadas pelas perguntas: Como foi a tua relação com a professora orientadora? De que forma aconteciam os encontros de assessoramento? Ficavas satisfeita com os assessoramentos e as orientações? Destaca alguns pontos positivos e negativos. As entrevistadas, de maneira geral, sentiram-se satisfeitas com o acompanhamento das professoras orientadoras. Nas disciplinas de Seminário, segundo elas, as professoras orientadoras costumavam trocar e-mails, uma vez que as alunas enviavam o plano semanal por via eletrônica, e a professora orientadora retornava com sugestões. Todas as respondentes disseram que os assessoramentos por e-mail funcionaram bem, já que complementavam os assessoramentos presenciais. Para a aluna A3-AI,

O trabalho em grupo pouco me ajudou, os assessoramentos coletivos [...]. Não tinha tempo para ouvir todas e atender todas nas suas especificidades. Aí como tinham meninas que era a primeira experiência em sala, necessitavam nesse momento de um pouco mais de atenção, então eu via que assim como eu, outras colegas do grupo também não eram atendidas, mas por questão de tempo. Não dava tempo para todo mundo falar das suas ansiedades, das suas necessidades e pensar alternativas para as dificuldades de cada uma. Mas a orientadora foi bem parceira, funcionaram bem os assessoramentos por $e$-mail, sempre que eu solicitei tive um retorno.

Pude perceber, pelos depoimentos das alunas, que as visitas aos locais de estágio não ocorrem a partir de um número definido previamente pelas professoras orientadoras. A3-AI, em sua entrevista, relatou que a orientadora a visitou em seu local de estágio três vezes, 
enquanto a entrevistada A1-EI relatou que sua orientadora visitou-a cinco vezes. Segundo a entrevistada,

Ela visitava a gente uma vez por semana ou a cada 15 dias no máximo. [...] A gente trocava muito material por e-mail, "olha, pensei em fazer isso, isso e isso", e ela dava retorno "olha, quem sabe tu muda isso, porque eu vi na tua sala que tinha isso", porque como ela tava muito presente nas nossas salas, ela conseguia acompanhar bem e dizer "isso de repente não, acho que isso vai fluir melhor do que aquilo".

Observo que a presença contínua da professora orientadora foi um ponto de destaque positivo referido pelas respondentes. Parece ter sido relevante nas tomadas de decisões no planejamento e na atuação docente das alunas. Ainda, ao ouvir as alunas e considerando as informações do Quadro 1, percebo que o número de orientandas para cada orientadora é um fato importante e, quem sabe, determinante para que as sugestões e interlocuções das professoras orientadoras sejam condizentes e adequadas aos acontecimentos das salas de aula das alunas estagiárias. Faço esse registro associado ao número de visitas que cada professora orientadora conseguiu realizar. A professora orientadora da aluna A3-AI realizou três visitas à sala de aula. A orientadora da aluna A1-EI realizou cinco visitas à sala de aula. Outro aspecto diz respeito ao número de alunas sob responsabilidade de cada professora orientadora. Cada professora orientadora da disciplina Seminário da Prática Docente - 6 a 10 anos se responsabilizou por cinco ou seis alunas. No entanto, na disciplina Seminário de Prática Docente - 0 a 7 anos atuaram duas professoras, que, conforme o relato das alunas entrevistadas, dividiram suas atribuições, uma ficou responsável por orientações mais teóricas e uma realizava as visitas às salas de aula e acompanhava os planejamentos, portanto, uma professora orientadora ficou responsável por quatro alunas. 
A aluna A4-EJA deu detalhes sobre as orientações:

[...] eram em grupos, eram cinco orientandas [...]. Ela [professora orientadora] sempre foi muito atenciosa, sempre me ajudou bastante, então, não sei te dizer uma coisa negativa. [...] Nas aulas a gente buscava discutir os textos, que, pra mim, me ajudaram bastante na prática do estágio.

A mesma aluna relatou que sua professora orientadora visitou-a apenas uma vez, porém ela mantinha contato com a professora titular.

Penso que a atuação das professoras orientadoras auxiliou as alunas a refletirem sobre suas práticas, pois, ao lerem os planejamentos e questionarem certas proposições, provocaram nas alunas o (re)pensar, além de ajudá-las no exercício do saber-analisar. Concordo com Perrenoud (2002b, p. 67) quando diz:

Formadores de campo devem estar envolvidos no processo de ensino. Em uma formação como esta pede-se que sejam profissionais reflexivos mais que professores exemplares e que aceitem compartilhar suas interrogações e dúvidas, bem como suas convicções e suas certezas, com os estagiários.

\section{0 curso de Pedagogia e a "retradução" dos saberes}

Conforme Tardif (2007, p. 53), nas experiências de atuação docente no caso deste estudo, o Estágio de Docência - é possível confrontar e repensar os saberes adquiridos durante a graduação, pois “[...] a prática cotidiana da profissão não favorece apenas o desenvolvimento de certezas 'experienciais', mas permite também uma avaliação dos outros saberes, através da sua retradução em função das condições limitadoras da experiência" (p. 53). Nesse sentido, percebi nas falas das entrevistadas algumas retraduções sobre estudos realizados no curso. 
A aluna A3-AI, ao relatar dificuldades em abordar tópicos matemáticos numa turma de $3^{\circ}$ ano e também em encontrar materiais facilitadores para o ensino, deu o seguinte depoimento:

Eu sempre sabia o que não fazer, as práticas que eu não queria ter, mas o que colocar no lugar, principalmente no que se referia ao ensino da Matemática assim, foi o grande desafio [...]. Nesse sentido o curso de Pedagogia ajudou pouco, em termos de instrumentos, de metodologias de sala de aula.

A aluna A4-EJA também fez uma retradução de seus estudos referentes ao ensino de tópicos específicos das áreas de conhecimento:

Aqui na faculdade eu vejo que a gente é bem focado, não sei assim, posso estar enganada, usando a palavra errada, mas bem politicamente, estão nos formando bem politicamente, bem o que é ser um professor ou como ser um bom professor e não mais específico nessas áreas.

Questionei as entrevistadas sobre os estudos e orientações referentes às áreas de conhecimento: Português, Matemática, Ciências, Geografia, História, Educação Física e Artes no curso. ${ }^{5}$ Cada uma dessas áreas possui um amplo campo de conhecimentos específicos, e o curso habilita a docência para atuar com turmas de $1^{\circ}$ ano a $5^{\circ}$ ano do Ensino Fundamental, isso sugere pensar: como capacitar as alunas para constituírem intervenções didático-pedagógicas pertinentes às especificidades de conhecimentos? Por exemplo, no curso de Pedagogia são oferecidas as disciplinas EDU02053 Linguagem e Educação I, EDU02057 Linguagem e Educação II e EDU02060 Linguagem e Educação III, que

${ }^{5}$ Conforme as DCNs para o curso de graduação em Pedagogia. 
abordam fundamentos sobre as linguagens verbais e não verbais, desenvolvimento da linguagem, alfabetização, letramento, conceitos básicos para o ensino da linguagem nos Anos Inicias e sugerem algumas metodologias. Essas disciplinas foram indicadas pelas alunas entrevistadas como importantes para a seleção de conteúdos e a elaboração de atividades para o ensino da Língua Portuguesa, como se observa na manifestação da A3-AI:

\begin{abstract}
A linguagem foi a área que a UFRGS mais especificamente mais contribuiu, em termos de fundamentos do trabalho com a linguagem, em termos de situações didáticas, de estratégias, de tu saber como fazer e como intervir, pra mim foi o grande destaque dessa graduação, foi a área da linguagem.
\end{abstract}

Observo que essas disciplinas totalizam uma carga horária de 165 horas-aula. Além disso, é oferecida, na primeira etapa do curso, a disciplina EDU02051 Análise e Produção do Texto Acadêmico, com carga horária de 30 horas-aula, ministrada pelas professoras da área de Linguagem.

Ao analisar as manifestações das alunas, percebi uma insistência em dar destaque à distribuição da carga horária para as disciplinas que tratam de abordagens específicas das áreas de conhecimento e como isso se relaciona com o preparo docente. A tomada de decisões de A1-EI relacionadas às especificidades dos conhecimentos se dá com base nos seus estudos e orientações recebidas no curso de Magistério - nível médio:

Nesse sentido eu não fico com tanto medo, porque se for me dar um currículo, eu tenho mais ou menos uma base de onde procurar, por causa do Magistério. Porque aqui [na UFRGS] eu senti muita falta disso, a gente não tem cadeiras específicas que se voltem para isso. 
Para ela, as disciplinas EDU02059 Educação Matemática I e EDU02065 Educação Matemática II, EDU03055 Ação Pedagógica de 0 a 10 anos, EDU02053 Linguagem e Educação I, EDU02057 Linguagem e Educação II e EDU02060 Linguagem e Educação III foram as mais colaborativas no sentido de agregar conhecimentos específicos. A aluna A2-EI explicita a situação de oferta da disciplina EDU02064 Ciências Sócio-Históricas na sexta etapa do curso. Vale observar o texto extenso da súmula da referida disciplina e o fato de que são muitas abordagens previstas para uma carga horária de 75 horas-aula! Na súmula disciplina consta o seguinte:

Ampliação e significação das experiências sociais das crianças, jovens e adultos, e construção de conhecimentos diversificados a respeito do meio cultural em que estão inseridas. Compreensão da importância do conhecimento dos fenômenos sociais e das práticas culturais do entorno das crianças, jovens e adultos pelo educador para sua presença na educação infantil e nos anos iniciais do Ensino Fundamental: diversidade das vivências socioculturais, das histórias familiares e comunitárias, dos modos de vida e de trabalho, dos lugares e suas paisagens, das relações com o tempo. Exploração da pluralidade de fenômenos e acontecimentos geográficos, históricos e culturais pelos estudantes, através da criação de momentos de aprendizagens significativas, da construção de conceitos, do desenvolvimento de estratégias pedagógicas voltadas às questões culturais e da articulação com outras áreas do conhecimento.

Para atendimento de suas abordagens, dois professores dividem a carga horária: um dá ênfase aos estudos afins à História, e outro aborda os estudos relacionados à Geografia. Segundo essa aluna: 
Sem dúvida eu vou ter que buscar [mais conhecimentos] porque tem disciplinas que a gente teve que eram muito curtas, créditos pequenos pro tamanho da demanda que a gente precisa ter, conhecer. Tipo a de História e Geografia era dividida um semestre para as duas, é ridículo, porque não conseguia aprofundar as coisas, tirar tuas dúvidas todas [...] Artes foi uma cadeira muito boa, eu gostei muito, achei que acrescenta bastante, faz a gente pensar muito, em termos de materiais e em como utilizar, apesar de ser muito curta, ela acrescentou muito.

A aluna A3-AI traz, em suas respostas, posições semelhantes às da colega A2-EI:

Em Matemática a gente teve brevemente fundamentos e um e outro conteúdo. Não vi, não sei de situações didáticas que nós tenhamos pensado nas aulas de Matemática, de ensino da Matemática. Então acho que a Matemática deixou a desejar. E acho que Ciências Naturais e Ciências Sócio-Históricas pra mim é como se elas não tivessem existido, porque a carga horária delas são mínimas no curso. Cada professor que trabalhou estas duas disciplinas, eles acabam dando conta muito mais dos seus estudos, das pesquisas que os professores já desenvolvem, do que propriamente a nossa necessidade de intervenção pedagógica e de conhecimento. [...] O que ficou pra mim foram falas sucintas, exemplos sucintos, nada mais concreto, mais complexo, de como a gente vai trabalhar isso em sala de aula. E na questão da Educação Física [...] não vejo que nós tivemos algum conteúdo, algum trabalho mais consistente 
com a metodologia de Educação Física, nem de como essa aula tem que ser pensada, em termos de atividades propostas, em termos de habilidades e de aprendizagens físicas, não vejo. [...] A de Artes, acho que ela foi bem interessante, embora uma disciplina com pouca carga horária, acho que foi bem válida, acho que ajudou e contribuiu na minha formação [...]. Achei que a disciplina de Música foi muito focada na Educação Infantil, que a gente viu nada de EJA e viu muito pouco aplicado aos Anos Iniciais.

É recorrente a referência à falta de conexão entre os estudos das disciplinas EDU02064 Ciências Sócio-Históricas e EDU02066 Educação em Ciências Naturais com as necessidades reais de uma sala de aula. As alunas reconhecem que essas disciplinas possuem pouca carga horária na proposta curricular do curso de Pedagogia e que, portanto, pouco dão conta de orientações metodológicas específicas. Duas alunas mencionaram a disciplina EDU02061 Educação e Artes Visuais, oferecida na quinta etapa do curso, como colaborativa na capacitação da docência. Chamou-me atenção que, em suas falas, não houve reivindicação de carga horária ampliada para essa disciplina. Quais os prováveis motivos? Poderia ser a pouca valorização desta área de conhecimento nas propostas curriculares, estando as alunas em formação mais preocupadas com áreas de conhecimento que predominam nos currículos escolares, como Matemática? Ainda com relação às áreas específicas do conhecimento, questionei as alunas com relação ao ensino das intervenções didático-pedagógicas da Educação Física. Essa área me pareceu um pouco negligenciada. Durante as entrevistas, como resposta, primeiro eu recebia um silêncio, como se as alunas estivessem tentando lembrar em que momento aprenderam sobre isso no curso. Concordo com o que a aluna A3-AI expressa: 
[...] não vejo que nós tivemos algum conteúdo, algum trabalho mais consistente com a metodologia de Educação Física, nem de como essa aula tem que ser pensada, em termos de atividades propostas, em termos de habilidades e de aprendizagens físicas.

A aluna A2-EI, quando questionada sobre a área da Educação Física, demorou para responder. Refletiu por um tempo e lembrou-se da disciplina EDU01049 Jogo e Educação, mas não soube expressar com clareza a sua opinião. Na súmula dessa disciplina consta o seguinte: "Estudo teórico-prático do jogo, do brinquedo e da brincadeira nas diversas fases do ciclo evolutivo e suas relações com a pesquisa e as práticas educacionais". Talvez por sugerir uma ideia de movimento, a aluna tenha estabelecido relação com estudos afins à Educação Física.

Acho preocupantes essas constatações! Com essas falas, recordo-me de alguns momentos em que realizei observação em uma Prática Pedagógica e, também, durante as observações do Estágio de Docência em que os períodos de Educação Física se resumiam a disponibilizar uma bola e uma corda para a turma. Tais discursos me fazem refletir sobre o que compete à formação inicial com relação aos conhecimentos básicos que devem ser adquiridos em uma graduação. E o que compete aos próprios professores na busca de mais conhecimentos? Há como definir um limite entre um e outro?

Há uma percepção das alunas sobre as limitações de preparo docente do curso, em suas respostas elas admitem que a busca "por mais" se faz necessária. A aluna A4-EJA falou: 
Eu acho que eu tenho que estudar, eu tive que estudar essas coisas pra eu poder passar pros alunos. [...] Acho que faz parte da profissão do professor, tu tem que estar sempre estudando. [...] A gente só teve uma cadeira de Ciências, duas de Matemática, então isso é pouco pra dar conta de $1^{\mathrm{a}}$ a $5^{\mathrm{a}}$ série [...]. A gente vai ter que estudar muito mais, mas acho também que faz parte, porque o currículo não pode dar conta de tudo, né?

Acredito que essa fala expressa um conceito presente na profissão docente, que é o da "incompletude". Saímos da graduação em Pedagogia com uma certeza: de que não estamos completas! Acho necessário analisar este conceito com mais profundidade, pois existe sim, na profissão docente, a necessidade de renovação constante, a busca por novas metodologias e também por mais capacitação durante a atuação docente, porém penso que esta renovação não significa o mesmo que buscar um conhecimento que deveria ser básico para uma Pedagoga. Com isso, percebo que, talvez, o problema resida na amplitude do curso de Pedagogia, pois ele possibilita um grande campo de atuação - da Educação Infantil aos Anos Iniciais, crianças, jovens e adultos (EJA) - e possivelmente o tempo de duração de quatro anos não seja suficiente para oportunizar tantas aprendizagens. Ao encontro dessas reflexões, Tardif (2007, p. 241) escreve:

Na formação de professores, ensinam-se teorias sociológicas, docimológicas, psicológicas, didáticas, filosóficas, históricas, pedagógicas, etc., que foram concebidas, a maioria das vezes, sem nenhum tipo de relação com o ensino nem com as realidades cotidianas do ofício de professor. Além do mais, essas teorias são muitas vezes pregadas por professores que nunca colocaram os pés numa escola ou, o que é ainda pior, que não demonstram interesse pelas realidades escolares e pedagógicas, as quais consideram demasiado triviais ou demasiado técnicas. 
Ao fazer esta crítica, o autor propõe que o desafio, nos cursos de formação, "[...] será o de abrir um espaço maior para os conhecimentos dos práticos dentro do próprio currículo" (Tardif, 2007, p. 241).

\section{A atuação docente pós-formação}

$\mathrm{Na}$ sétima etapa do curso de Pedagogia, as alunas optam por uma das modalidades de Estágio de Docência - 0 a 3 anos ou 4 a 7 anos ou 6 a 10 anos ou EJA-, realizando 300 horas/aula no mesmo local/turma. Ao considerar essa opção curricular, eu formulei a seguinte questão: "Tu te sentes preparada para atuar como professora em turmas/faixas etárias não contempladas pelo Estágio de Docência realizado por ti?”. A aluna A3-AI respondeu que não se sente preparada

[...] no sentido de saber tudo. [...] Na universidade eu vejo pouco espaço para discutir as questões de planejamento de sala de aula, então a gente tem uma carga horária significativa dos fundamentos da educação e depois tu parte para a reflexão, me parece que a questão que fala do planejamento, no dia a dia, das intervenções pedagógicas, eu acho que a universidade deixa a desejar. Mas ao mesmo tempo me sinto preparada entre aspas, no sentido de que tô disponível para aprender, para ir atrás das coisas, mas despreparada no sentido da universidade; não acho que a universidade me preparou, se não fosse essa minha experiência que eu tenho fora da universidade e a minha disposição para buscar fora. Eu acho que a universidade não deu conta dessa preparação.

Destaco dois aspectos da fala dessa entrevistada. O primeiro se refere à preparação docente que está sendo oferecida pelo curso, pois, segundo ela, é pouco efetiva no que se refere às questões práticas do dia a dia de uma professora. Outro aspecto se refere à sua própria 
vontade de buscar aperfeiçoamento. Ela afirmou não se sentir preparada para a atuação em classes de Educação Infantil e/ou de EJA, uma vez que realizou o Estágio de Docência em uma classe de $3^{\circ}$ ano do Ensino Fundamental. Entretanto, eu percebi, durante a entrevista, que essa aluna apresentava desenvoltura ao se referir às rotinas em classes de Anos Iniciais, e tal constatação me faz pensar que essa aluna pode constituir "saberes experienciais", conforme Tardif (2007) propõe. Ainda, ao se dispor "para aprender, para ir atrás das coisas", a aluna se mostra em condições de exercer essa busca com autonomia. Isso me parece ser um indício de que ela está preparada, talvez não percebendo sua postura aberta e disponível para essa busca como uma competência constituída no curso.

Sem discordar da posição da aluna sobre a necessidade de aprimoramento da proposta do curso de Pedagogia, dando mais ênfase às orientações metodológicas mais específicas, percebo que a ideia de "incompletude" parece deixar as alunas ansiosas, ou seja, não é mencionada a possibilidade de formação em serviço, e a proposta do curso de graduação - uma formação inicial - adquire um sentido de formação final.

A colega A4-EJA deu o seguinte depoimento:

Olha, eu acho que preparada a gente nunca tá $100 \%$ preparada, né? Pra Educação Infantil eu me sentiria à vontade pra sair agora da Faculdade e trabalhar, porque eu fiz Minipráticas lá e eu acho que foram boas, tive um bom retorno. Como eu nunca fiz Miniprática nos Anos Iniciais eu não sei te dizer, já não me sinto tão à vontade. Eu acho que a Faculdade dá uma boa ideia das Séries Iniciais e da Educação Infantil, mas acho que não é uma coisa fácil. Eu acho que tenho que me aprofundar mais [...]. Eu acho que pra uma turma de Séries Iniciais, com crianças, não me sinto preparada, eu teria que 
estudar, sei lá, fazer uma Pós ou eu mesma pegar e estudar. Também não acho uma missão impossível, né?

As ditas minipráticas são coordenadas pela disciplina Seminário das quarta, quinta e sexta etapas do curso. Na quarta etapa, obrigatoriamente, a faixa etária para a prática varia de 0 a 4 anos, correspondendo a classes de Educação Infantil. Entretanto, na quinta etapa, a obrigatoriedade da faixa etária para a prática, ao variar entre 4 a 7 anos, permite a escolha pelas alunas entre classes de Educação Infantil e Anos Iniciais do Ensino Fundamental. Também, na sexta etapa, a obrigatoriedade da faixa etária para a prática, ao variar entre 6 a 10 anos ou EJA, permite às alunas a escolha por classes com crianças ou jovens e adultos. Faço essa ressalva, pois observo que a aluna, ao ter intensificado suas experiências práticas nas classes de Educação Infantil, fez isso por escolha. Na fala da colega, percebo a ideia de incompletude do "ser professor" e também a disposição para buscar por mais conhecimentos, o que, no meu entender, pode ser uma disposição para a formação continuada, ao referir uma "pós-graduação".

A disposição para a continuidade de estudos irá depender da necessidade individual, apresenta-se como uma busca subjetiva. Uma egressa do curso de Pedagogia, apenas com essa formação inicial, pode se sentir à vontade para atuar em classes dos níveis de ensino para os quais o curso habilita o magistério - Educação Infantil e Anos Iniciais do Ensino Fundamental (crianças, jovens e adultos), enquanto outra egressa, mesmo habilitada, não se sente preparada. Portanto, os saberes da formação profissional e os saberes disciplinares (Tardif, 2007) são adquiridos e apropriados pelas alunas em formação de diferentes maneiras, não sendo possível estabelecer um padrão de aprendizagens. 


\section{CONSIDERAÇÕES FINAIS}

Através deste estudo pude perceber o quanto a formação docente está imbricada na realização do Estágio de Docência para as alunas do curso de Pedagogia. Para as alunas, o Estágio de Docência proporciona a constituição de aprendizagens para um manejo pedagógico, principalmente quando acontecem imprevistos. Um achado deste estudo foram os depoimentos das alunas sobre a experiência no Estágio de Docência referente à docência compartilhada, uma prática que as ajudou a planejar e, também, a atuar em sala de aula.

Destaco os dados obtidos nas entrevistas com relação às disciplinas vinculadas mais diretamente aos saberes das áreas de conhecimento. As áreas de História, Geografia, Matemática, Ciências e Educação Física foram as mais citadas como "incompletas" em função de o curso, na opinião das respondentes, não ter oportunizado aprendizagem específica de metodologias.

Ainda, um achado que considero merecedor de mais estudos se refere ao conceito de "incompletude" docente. As entrevistadas demonstraram e reconhecem que, para a atuação docente, é necessário uma formação continuada, e isso se faz pela busca de mais conhecimentos. Embora reconheçam falta de aprendizagens mais específicas no curso, não esperam estar completamente formadas ao fim dele.

Nesse sentido, a reflexão que faço é: como determinar o que deve competir à formação inicial e o que será atribuído à formação continuada? Por onde se devem balizar os conhecimentos essenciais e necessários à formação da/o pedagoga/o? Afinal, a busca por mais conhecimentos, após a conclusão da graduação, será algo subjetivo, dependerá da necessidade individual, como, por exemplo, nível de ensino em que irá atuar, especificidades metodológicas afins à escola em que irá trabalhar, etc. Isso fortalece a ideia de que a "incompletude" é transitória, dependerá 
da área, do momento, do contexto em que nós, pedagogas, estivermos inseridas, assim como tem relação com a busca do que nos falta.

Estas análises me fizeram refletir sobre o tempo de duração - quatro anos - do curso de graduação em Pedagogia. Serão esses anos suficientes para dar conta das especificidades pedagógicas e curriculares exigidas pelas Diretrizes Curriculares Nacionais e das quais o curso se propõe - magistério na Educação Infantil e Anos Iniciais (crianças, jovens e adultos)? Além dessa reflexão, estudar sobre o Estágio de Docência e o curso de Pedagogia modificou minha visão e opinião sobre a formação docente. Penso, agora, que a qualidade da formação não está no número de cursos realizados, e sim na postura assumida pela aluna diante dos conhecimentos. Acredito que, ao longo do curso de Pedagogia, faz-se necessária uma mudança na postura discente, passando de estudante à professora. Ao assumir o "lugar" docente e as responsabilidades da profissão docente, a aluna está constituindo sua formação. Quero dizer que a maneira como nós, alunas em formação, interagimos com os conhecimentos e nos apropriamos deles pode repercutir em maior ou menor qualidade em nossa formação.

Portanto, com esse estudo, pude compreender que o curso de Pedagogia pode um dia passar por uma mudança curricular - na duração, nas abordagens das disciplinas, etc. -, porém isso não será suficiente, pois a formação docente se constitui, ela não é "dada” e depende, em grande parte, da postura assumida pelos alunos-estagiários-professores. Talvez a questão que ainda suscita um estudo posterior seja: qual o papel assumido pelo aluno na formação docente?

\section{REFEREิNCIAS}

BRASIL. Lei $n^{\circ}$ 9.394, de 20 de dezembro de 1996. Estabelece as diretrizes e bases da educação nacional. Brasília, 2006. Disponível em: <http://www. planalto.gov.br/ccivil_03/leis/19394.htm>. Acesso em: 3 mar. 2017. 
BRASIL. Ministério da Educação. Conselho Nacional de Educação. Conselho Pleno. Resolução CNE/CP no 1, de 15 de maio de 2006. Institui diretrizes curriculares nacionais para o curso de graduação em Pedagogia, licenciatura. Diário Oficial da União, Brasília, DF, 16 maio 2006. Seção 1, p. 11-12.

. Ministério da Educação. Conselho Nacional de Educação. Conselho Pleno. Resolução $C N E / C P n^{\circ}$ 2, de 19 de fevereiro de 2002. Institui a duração e a carga horária dos cursos de licenciatura, de graduação plena, de formação de professores da Educação Básica em nível superior. Disponível em: $<$ http:// portal.mec.gov.br/cne/arquivos/pdf/CP022002.pdf>. Acesso em: 6 mar. 2017.

LÜDKE, M.; ANDRÉ, M. E. Pesquisa em educação: abordagens qualitativas. São Paulo: EPU, 1986.

PERRENOUD, P. As competências para ensinar no século XXI: a formação dos professores e o desafio da avaliação. Tradução de Cláudia Schilling e Fátima Murad. Porto Alegre: Artmed, 2002a.

PERRENOUD, P. A prática reflexiva no ofício de professor: profissionalização e razão pedagógica. Tradução de Cláudia Schilling. Porto Alegre: Artmed, 2002b.

SANTOMÉ, J. T. Globalização e interdisciplinariedade: o currículo integrado. Porto Alegre: Artes Médicas, 1998.

TARDIF, M. Saberes docentes e formação profissional. Petrópolis, RJ: Vozes, 2007.

UNIVERSIDADE FEDERAL DO RIO GRANDE DO SUL. Conselho de Ensino, Pesquisa e Extensão. Resolução no 4, de 28 de janeiro de 2004. Regulamenta as diretrizes para o plano pedagógico das licenciaturas da UFRGS. Porto Alegre, 2004. Disponível em: <http://www.ufrgs.br/cepe/ legislacao/resolucoes-normativas/resolucao-no-04-2004-de-28-01-2004>. Acesso em: 3 mar. 2017.

. Faculdade de Educação. Comissão de Graduação. Projeto pedagógico do curso de Pedagogia. Disponível em: <http://www.ufrgs.br/faced/comissoes/comgrad/Projeto\%20Pedag\%C3\%B3gico\%20Certificado.pdf>. Acesso em: 6 mar. 2017. 


\section{Memórias da formação: aprendendo a conhecer e a ser aquela que ensina $e$ aprende}

Isaura Teresinha Silva Barbieri

\section{PRIMEIRAS PALAVRAS}

Tendo realizado investigação e análise da realidade escolar no primeiro semestre do ano de 2013, ao (re)pensar meu próprio fazer pedagógico, enquanto trabalhadora em Educação, assumo-me como sujeito crítico que, comprometido com estratégias reflexivas e práticas educativas concebidas, na maioria das vezes, sob uma perspectiva política, defende uma prática pedagógica emancipadora e transformadora. Nesse sentido, a escrita de si, assumida como modo de pesquisa, configura-se como gênero discursivo privilegiado para nós, educadores. A partir dela, podemos escrever nossas histórias, comunicando saberes e conhecimentos. Nesse processo formativo e reflexivo que cada pessoa faz de si mesma, nesse relato que envolve apropriação de seu próprio patrimônio existencial, poderá ocorrer a compreensão do processo de formação pessoal e profissional.

O Memorial Formativo é uma narrativa reflexiva, uma possibilidade interessante e estimulante à análise sobre a escola e seus contextos de aprendizagens. Instrumento importante para a reflexão sobre como 
nos tornamos o que somos, ou seja, do porquê e do modo pelo qual nos tornamos educadores e, para além, o Memorial de Formação se traduz como um texto sobre esses acontecimentos, não apenas uma narrativa deles. Nesse sentido, posso dizer que o exercício dessa escrita autobiográfica é uma tarefa que, além de implicar o registro da própria trajetória, faz com que cada autor reflita a respeito do que viveu (o que nem sempre é prazeroso e habitual), mobilizando conhecimentos, saberes, crenças, emoções e o estabelecimento de relações não necessariamente percebidas até então.

Essa perspectiva pressupõe um sujeito protagonista de seu percurso de formação e dos diálogos que se estabelecem em sua atuação profissional. Compreendendo que a vida não pode ser separada do modo pelo qual podemos capturar a nós mesmos, lembro Benjamin (1994), pois, ao narrar histórias, efetivamente, estarei configurando a construção da minha identidade. E assim, permanente e sucessivamente, (re) inventando-me.

O Memorial Formativo, devido à sua natureza reflexiva, segundo Josso (apud Buogo; Castro, 2012), torna visíveis diferentes aprendizagens tanto na dimensão individual quanto na coletiva. É uma escrita que não se esgota em si mesma, transcende fronteiras e se apropria da compreensão retrospectiva que cada pessoa faz de si, num exercício de produção de memórias que provoque cada professor em formação a re(vi)ver seu percurso. Re(vi)ver a trajetória escolar e refletir sobre o desenvolvimento profissional, porque somos profissionais na e da escola ou outros espaços de formação, permite que aquele que escreve reconheça o seu "saber que sabe" a partir da percepção crítica de suas possibilidades, limites, implicações e compromissos.

Esse reconhecimento acontece na religação desses saberes, na compreensão desses mesmos processos formativos, os quais foram potencializados no conhecimento de si e do outro, da sua própria vida e do 
seu trabalho. O sujeito, pois, efetiva essa escrita no registro dessas lembranças e reminiscências de ontem com a possibilidade de significação de hoje, (re)inaugura um novo sentido dessa trajetória na concretude e experimentação, enquanto aprendente e educador.

\section{UM SUJEITO CONSTITUIDDO: CAMINHOS PERCORRIDOS}

A relação intrínseca entre o passado e o presente, através da compreensão das vivências e das representações que foram constituídas entre os sujeitos, é que deu subsídios para as escolhas didáticas e metodológicas dos educadores e para o seu posicionamento frente à realidade e à diversidade dos alunos. Como assinala Soares (1991), esse encontro é sempre do pensamento atual, recuperando o passado, pois o presente projeta-se sobre o passado. Dessa forma, é necessário considerar que a identidade docente é constituída pela totalidade das experiências do educador, assim como por aquelas marcas deixadas pelos nossos professores que, nem sempre prazerosas, também nos influenciaram para mais ou para menos nessa jornada.

Fomos alunas e sabemos que, se imobilizados com atividades repetitivas e monótonas, os alunos se cansam e se desmotivam na ação de aprender. É necessário estímulo e motivação para o percurso educacional. Como educadores, percebemos que, muito embora tenham mudado o perfil e a identidade dos alunos, a principal função da educação ainda é a da acolhida do outro, porque cuidar da condição humana é primordial na nossa profissão! Efetivamente, a escola produz identidades, ao produzir subjetividades, que se repetem, se reproduzem, mesmo diferentes, contribuindo para a construção da identidade dos sujeitos, na medida em que considera a heterogeneidade deles, sem menosprezar suas diferenças.

Através da rememoração da minha história, busquei uma metodologia que abrangesse aspectos cognitivos e afetivos envolvidos nessa pesquisa-formação, no conhecimento de si, do outro e do mundo. Nesse 
sentido, a minha história de vida, em grande parte, foi aquela das minhas aprendizagens e da relação biográfica com o saber e o aprender (Buogo; Castro, 2012).

\section{CAMINHOS SENDO PERCORRIDOS, SABERES SENDO CONSTRUIDOS}

Como o indivíduo, histórica e ontologicamente, não é um ser para adaptações, e sim, indiscutivelmente, de transformações, o resgate das minhas memórias do vivido poderá proporcionar a reflexão crítica sobre o processo de compreensão iluminado por autores que tratam da complexidade da condição humana e de suas implicações na docência, na capacidade humana de sentir o outro, a si mesmo e ao meio, nas múltiplas relações e inter-relações da realidade da comunidade educativa.

Por ser um indivíduo, portanto um ser social, na rica totalidade de determinações e relações entre os envolvidos neste processo de aprendizagens, é que venho pensar minha atual posição no sistema educativo. Nessa ação-reflexão, é que dou sentido à minha vida. Ao registrar esse exercício, indo além das questões que os educandos colocam, sujeitos históricos de seu tempo, venho buscar intimidade na prática da minha sala de aula, na construção desse processo coletivo de aprendizagens, no qual "todos aprendemos juntos".

Embasada no princípio de que minha ação pedagógica deva vir carregada de intencionalidades, numa análise da complexidade da condição humana e suas implicações na docência, fui capaz de capturar emoções, sentimentos e significações dessas experiências vivenciadas, significadas e ressignificadas na contextualidade presente. Trilhando esse caminho da não homogeneização na produção histórica das identidades humanas, encontrei-me numa (re)leitura inquietante, não assegurada, desassossegada, vinculada a um viés libertário e emancipador (a plena essência da educação) que urge na educação do presente. Mesmo porque, nessa (re)leitura inquietante, não só me ocupo 
com o aqui e o agora, mas, principalmente, com a convivência de grupo no reconhecimento e entendimento do outro, na transformação daquilo que somos e queremos ser.

Mais uma vez, creio e reafirmo que é na resolução de conflitos, na realidade diária da escola, que se pode intermediar negociações no grupo, a troca de experiências e a valorização dos modos de ser, fazer e viver a cultura das crianças, efetivamente no reconhecimento de seus saberes. Para tanto, há de se educar com o coração, no acolhimento, para a inteireza do ser, interrogando-se sobre o planeta Terra, o homem e o próprio conhecimento, viabilizando o estabelecimento da lucidez e das incertezas. Ou seja, numa humanização do atendimento, posto que signifique lutar por mudanças de atitudes e de culturas, nas quais se fortaleçam ideais humanísticos coletivos e institucionais, através da ética e da cidadania como forma de valorização da vida - bem maior da nossa existência. Efetivamente, num trabalho diário de construção de um mundo melhor, mais fraterno, justo, saudável, feliz e, sobretudo, mais pleno do humano. Nessa prática, pode-se rejeitar a violência ativa em todas as suas formas (físicas, sociais, sexual, psicológica, econômica) contra os mais vulneráveis e menos favorecidos, como nossas crianças e adolescentes, no âmbito escolar e fora dele. No campo educativo, essa postura ressignifica o espaço escolar, exigindo a construção de diferentes redes de apoio, com processos inclusivos e integração de estratégias associadas à intervenção precoce por meio de ações e metas que deem visibilidade aos conflitos, possibilitando sua identificação, através da leitura de informações do contexto. Então, faz-se necessário que, para a transformação de uma cultura de violência em uma cultura de convivência, mudemos nossa maneira de pensar, contrapondo-nos a uma cultura de indiferença, desvalorização, individualismo e preconceito exacerbado.

Assim, meu compromisso social, como educadora, assenta-se em vínculos afetivos entre os sujeitos educativos, na possibilidade de uma aprendizagem significativa, no prazer da cooperação, do compartilhamento, 
da solidariedade, de crianças e jovens felizes e de adultos dignos de confiança deles, nos outros e em si mesmos.

\section{(IN) $\varepsilon X C L U S \tilde{\varepsilon S ~}$}

Esta escrita autobiográfica, como dispositivo de formação, revelou meu momento de sujeito, enquanto "objeto da pesquisa", ao narrar minha evolução, configurando uma forma de história autorreferente, portanto, plena de significados, em que me vejo e me desvelo, tanto para mim mesma quanto para os demais. Por isso mesmo, foi a memória, elemento-chave deste trabalho de pesquisa autonarrativa, ressignificada ao longo do processo reflexivo e de interiorização. Na maior parte das vezes, lembrando e não revivendo, mas refazendo, reconstruindo, repensando, com imagens e ideias de hoje, as experiências do passado.

Concordo com Morin (2003) quando assinala que o conhecimento humano não é nato, mas se configura como construção do sujeito, através da ação sobre o objeto, numa interação perceptiva ou reflexiva sobre este. Portanto, cheia de saberes perdidos no espaço-tempo, que o sujeito, com paciência histórica, tenta contextualizá-los para adquirirem uma dimensão auto-organizante, reparativa, educativa e evolutiva da singularidade humana na sua diversidade e complexidade.

São esses mesmos indivíduos que, através de seus traços biológicos, psicológicos, intelectuais, culturais e sociais, carregam suas particularidades, singularidades e subjetividades nos modos de "viver" e "enxergar" o mundo em que habitam e convivem. Na complexa realidade cotidiana escolar atual, ainda há de se pensar no compromisso social da educação, que inspire iniciativas de exercícios e práticas significativas para a efetiva transformação que se quer ver no mundo, de tal modo a tornar possível uma cultura colaborativa. Nesse caminho de me (re)descobrir na solidariedade da condição humana, no fortalecimento das relações de confiança, é que se torna imprescindível essa mudança, a qual já posso perceber na convivialidade com meus alunos 
em sala de aula. Com essa prática cotidiana, vislumbro essa metamorfose através de pequenos hábitos, como uma atitude, uma palavra, na demonstração das próprias aprendizagens escolares, nesse lugar de conscientização e compreensão do outro.

A educadora, para além de seus aportes teórico-práticos, necessita estar ciente de sua responsabilidade (social, ética, afetiva, cognitiva e política) na humanização de suas crianças e seus adolescentes, priorizando a formação de cidadãos críticos e engajados no contexto da atualidade. Trata-se de se perceber e ao mundo real e de reconhecer as potencialidades e possibilidades de mudança dessa mesma realidade. Efetivamente, trata-se de formar alunos no seu desenvolvimento permanente, atuante, observador e crítico do mundo à sua volta.

Durante minha formação, os conhecimentos adquiridos na trajetória estudantil foram ressignificados e sofreram adaptações, tal qual os dos meus alunos irão se transformar. Assim, direi que a identidade estudantil, em qualquer faixa etária, funciona como num ciclo: uma vez exposta, faz com que façamos novas escolhas, acomodando, em constante processo de identificação, construindo e (re)construindo nossas ações e práticas educativas. Esta não é automática, exige uma posição pessoal, politizada, ativa, coletiva, subjetiva, instável, objetiva, institucional, estrutural e social: uma identificação. Essa vivência acontece através de escolhas de cada um, de suas práticas, interações e intervenções, efetivamente, de suas ações.

A identidade docente também é coletiva, sendo constituída nos diferentes espaços de atuação deste profissional, num exercício de troca, partilha, conquistas, dúvidas, ansiedades, sonhos, ideais, crenças, valores e aprendizagens pessoais. Nesse estudo, pude aperceber-me de que as imagens e representações que construímos em nossas vivências anteriores irão influenciar as nossas escolhas metodológicas, a nossa postura frente 
ao alunado, aos docentes e à comunidade escolar, nas relações interpessoais - o que poderá ser mudado, de acordo com o público que atendemos.

Este processo de reflexão sobre o saber prévio e o saber adquirido em cada aula deve se dar no contexto diário da formação de um professor. Assim, a prática reflexiva é um exercício necessário para que haja sempre o amadurecimento do profissional. $\mathrm{O}$ educador necessita ter consciência do que faz, para quem faz, por que faz seus planejamentos, confrontando a situação passada com a atual e, assim, aperfeiçoando o seu fazer pedagógico.

Nesse sentido, refletir sobre a ação é aperfeiçoar a prática, reorganizando a ação de acordo com os saberes e as necessidades do alunado, pois, ao refletir sobre minha ação pedagógica, estarei atuando como uma pesquisadora da própria sala de aula. Dessa forma, deixo de seguir cegamente as prescrições impostas pela gestão escolar e pelo sistema de ensino, ou pelos esquemas preestabelecidos nos livros didáticos, não dependendo de regras, técnicas, guia de estratégias e receitas decorrentes de uma teoria proposta/imposta de fora, tornando-me uma produtora de conhecimento, profissional e pedagógico, juntamente com meus alunos. Uma educadora que, ao ensinar, também aprende.

Nessa prática reflexiva, o intuito é tornar a professora produtora de seu próprio fazer e saber pedagógico, estabelecendo suas próprias prioridades e formas de ação docente, sem ficar atrelada aos paradigmas tradicionais da educação, às imposições externas ou a representações negativas.

\section{CONCLUSÕES POSSIVEIS}

Com a certeza de que não há como findar o estudo sobre assuntos complexos como este em apenas um artigo desta proporção, ansiei por circunscrevê-lo na problematização desta temática. Assim, ao elaborar este trabalho, percebi que o processo de identificação com a profissionalização ocorreu desde o princípio da escolaridade, estendendo-se até os dias 
atuais da prática docente, diariamente, significando determinados saberes e constituindo outros. Nesse processo, a influência da didática pedagógica de cada professor(a) e, concomitantemente, a aprendizagem de seus alunos configuram, novamente, um processo cíclico, mediado pelas suas próprias representações e vivências de seus alunos. Assim, nossa identidade tem relação com nossas vivências, e dessa forma, enquanto professora, fui norteada pelas imagens que construí desde a idade escolar, perpassando a formação inicial, estendendo-se até a minha prática docente cotidiana.

Diante dessa perspectiva, as principais representações que foram registradas pelas nossas professoras são inerentes à nossa atuação profissional, seja de forma implícita ou explícita, as quais percebemos quando refletimos sobre nosso fazer pedagógico, fazendo um elo com o que vivenciamos - enquanto alunas da educação básica - e o vivido na atualidade.

Ser professora, hoje, faz-me pensar em que docente fui constituída e, ao refletir sobre esta prática, ao relembrar o ontem, enquanto aluna, faz com que eu valorize ainda mais o papel da professora. Daquela que ensina, mas que também aprende com as experiências dos alunos: que sabe escutá-los, que identifica no olhar e, com um gesto de carinho e na aproximação, consegue confortá-los, fazer com que desabafem, nem sempre em palavras, mas com outro olhar, aquilo que sentem e o que precisam. Percebo-me, ao refletir sobre meu fazer pedagógico, uma pessoa mais atenciosa e afetiva com os alunos, conhecendo e conseguindo identificar cada aluno que compõe a instituição, suas dificuldades, seus comportamentos, sabendo da importância que têm o olhar e a escuta da professora. Com isso, esta pesquisa proporcionou um olhar mais aprofundado de meu passado, enquanto aluna, fator que me possibilitou a percepção das representações que construíram minha identidade docente, as problematizações e discussões acerca de 
minha vivência educacional, a troca de experiências, mais uma vez, do passado se fazendo presente nos dias de hoje.

Contar, compor e escrever minha história e trajetória, formatar, colorir e textualizar as lembranças destas experiências estudantis, profissionais e acadêmicas, como exercício estético e reflexivo indispensável exigido num Memorial de Formação, rememorando o vivido e refletindo a compreensão do vivenciado, sobretudo, na reinvenção da educação do presente: do aqui e do agora. Essas são as verdadeiras possibilidades deste trabalho, que envolveu reviver meus itinerários de professora, construí-los e reconstruí-los com as marcas do presente, a partir dessa relação entre passado, presente e futuro.

\section{REFERÊNCIAS}

BENJAMIN, W. Magia e técnica, arte e política: ensaios sobre literatura e história da cultura. 2. ed. São Paulo: Editora Brasiliense, 1994. (Obras escolhidas, v. 1).

BUOGO, M.; CASTRO, G. Memorial de formação: um dispositivo de aprendizagem reflexiva para o cuidado em saúde. Trabalho, Educação e Saúde, Rio de Janeiro, v. 11, n. 2, p. 431-449, maio/ago. 2012.

MORIN, E. A cabeça bem-feita: repensar a reforma, reformar o pensamento. Tradução Eloá Jacobina. 8. ed. Rio de Janeiro: Bertrand Brasil, 2003.

SOARES, M. Metamemórias, memórias: travessia de uma educadora. São Paulo: Cortez, 1991. 


\section{AS AUTORAS}

\section{Andréia Rosa da Silva Kurroschi}

Licenciada em Pedagogia pela Universidade Federal do Rio Grande do Sul. Atua como professora em uma escola da rede particular de Porto Alegre. Desde 2014 atua como supervisora do projeto Saberes Indígenas na Escola, núcleo UFRGS.

E-mail: andreiarsk@gmail.com

\section{Angela Cristina Sthamer Gieseler}

Licenciada em Pedagogia pela Universidade Federal do Rio Grande do Sul. Atua como estagiária na Empresa STIHL.

E-mail: angela_gieseler@hotmail.com

\section{Bruna da Cunha Fagundes}

Licenciada em Pedagogia pela Universidade Federal do Rio Grande do Sul. Integra o quadro de servidores do Departamento Estadual de Trânsito do Rio Grande do Sul, no cargo de auxiliar técnico em administração, lotada na Divisão de Exames Teóricos.

E-mail: bruna_cunha_fagundes08@yahoo.com.br

\section{Catarine Machado Costa}

Licenciada em Pedagogia pela Universidade Federal do Rio Grande do Sul. Atua como professora na Escola de Ensino Fundamental La Salle Pão dos Pobres.

E-mail: catarinemcosta@gmail.com 


\section{Cristiane Luiza Abbud Flores}

Licenciada em Pedagogia pela Universidade Federal do Rio Grande do Sul. Atua como professora em uma escola de educação infantil da rede federal em Porto Alegre.

E-mail:crislu_flores@hotmail.com

\section{Fabiana de Miranda Rocha}

Licenciada em Pedagogia pela Universidade Federal do Rio Grande do Sul. Atua como professora auxiliar, responsável pela biblioteca infantil, em uma escola da rede particular de Porto Alegre. Na Faculdade de Educação da UFRGS, atua como apoio pedagógico, técnico e administrativo no curso de Especialização em Coordenação Pedagógica - MEC/ UFRGS.

E-mail: fabiana.mrocha@terra.com.br

\section{Isaura Teresinha Silva Barbieri}

Licenciada em Pedagogia pela Universidade Federal do Rio Grande do Sul. Atua como professora em uma escola da rede municipal de Porto Alegre. E-mail: isaura.barbieri2013@yahoo.com.br

\section{Juliana Hass Massena}

Licenciada em Pedagogia pela Universidade Federal do Rio Grande do Sul. Especialista em Alfabetização e Letramento. Professora da rede municipal de Eldorado do Sul desde 2008, atuando ora na docência nos anos iniciais do ensino fundamental, ora na coordenação pedagógica da escola.

E-mail: jujuhass@gmail.com 


\section{Lidiane da Silva Machado}

Licenciada em Pedagogia pela Universidade Federal do Rio Grande do Sul. Atua como professora de educação infantil em uma escola da rede particular de Porto Alegre.

E-mail: lidiane01@gmail.com

\section{Maria Bernadette Castro Rodrigues}

Licenciada em Pedagogia e mestre em Educação pela Universidade Federal do Rio Grande do Sul. Atuou no curso de Pedagogia da UFRGS no período de 1985 a 2014. Professora aposentada.

E-mail: bcrodrigues61@gmail.com

\section{Márjori Bez Reus}

Licenciada em Pedagogia pela Universidade Federal do Rio Grande do Sul. Atua como professora em uma escola de educação infantil da rede particular de Porto Alegre.

E-mail:marjorireus@gmail.com

\section{Patricia Alejandra Behar}

Bacharel em Informática pela Pontifícia Universidade Católica do Rio Grande do Sul, mestre e doutora em Ciência da Computação pela Universidade Federal do Rio Grande do Sul. Professora titular da Faculdade de Educação e dos Programas de Pós-Graduação em Educação e de Informática na Educação da UFRGS. Coordena o Núcleo de Tecnologia Digital Aplicada à Educação (NUTED) da UFRGS e atua como vice-coordenadora do curso de Pós-Graduação em Informática na Educação da UFRGS.

Email: pbehar@terra.com.br 


\section{Priscila de Abreu Bortoletti}

Licenciada em Pedagogia pela Universidade Federal do Rio Grande do Sul. Especialista em Língua Brasileira de Sinais pela UNIASSELVI. Atua como professora dos anos iniciais em uma escola da rede federal em Porto Alegre.

E-mail:pri.abreu90@gmail.com

\section{Simone de Brum}

Licenciada em Pedagogia pela Universidade Federal do Rio Grande do Sul. Cursa Especialização de Gestão Estratégica de Pessoas na Pontifícia Universidade Católica do Rio Grande do Sul. Atua como técnica administrativa na Pró-Reitoria Acadêmica da PUCRS.

E-mail:moni.brum@gmail.com

\section{Tássia Priscila Fagundes Grande}

Licenciada em Pedagogia pela Universidade Federal do Rio Grande do Sul e especialista em Psicopedagogia e Tecnologias da Informação e Comunicação pela mesma universidade. Cursa Mestrado em Educação no Programa de Pós-Graduação em Educação (PPGEDU) na UFRGS. Atua como bolsista CAPES/PPGEDU (UFRGS) e como pesquisadora junto ao Núcleo de Tecnologias Digitais Aplicadas à Educação (NUTED/UFRGS) na área de desenvolvimento de tecnologias para a educação.

Email: tpri.fagundes@hotmail.com

\section{Viviane Malheiro Barbosa}

Licenciada em Pedagogia pela Universidade Federal do Rio Grande do Sul. Cursa Mestrado em Educação no Programa de Pós-Graduação em Educação (PPGEDU)-UFRGS. Bolsista do CNPq, investiga trajetórias de mulheres capoeiristas em espaços escolares. Atua na Capoeira Angola. E-mail: vivimalheiro@hotmail.com 
Este livro foi composto na tipologia Adobe Garamond Pro em corpo $12 \mathrm{pt}$ e impresso no papel Offset $75 \mathrm{~g} / \mathrm{m}^{2}$ na Gráfica da UFRGS

Editora da UFRGS • Ramiro Barcelos, 2500 - Porto Alegre, RS - 90035-003 - Fone/fax (51) 3308-5645 - editora@ ufrgs.br - www.editora.ufrgs.br • Direção: Alex Niche Teixeira • Editoração: Luciane Delani (coordenadora), Clarissa Felkl Prevedello, Cláudio Marzo da Silva, Cristina Thumé Pacheco e Lucas Ferreira de Andrade • Administração: Aline Vasconcelos da Silveira, Cláudio Oliveira Rios, Fernanda Kautzmann, Gabriela Campagna de Azevedo, Getúlio Ferreira de Almeida, Heloísa Polese Machado, Janer Bittencourt, Jaqueline Trombin e Laerte Balbinot • Apoio: Luciane Figueiredo 